\title{
nombalina
}

(8)

\section{Luciano II}
Autor(es):
Luciano de Samósata
Publicado por: Imprensa da Universidade de Coimbra; Centro de Estudos Clássicos e Humanísticos

URL

persistente:

URI:http://hdl.handle.net/10316.2/9727

DOI:

DOI:http://dx.doi.org/10.14195/978-989-26-0800-6

Accessed : $\quad$ 26-Apr-2023 11:28:17

A navegação consulta e descarregamento dos títulos inseridos nas Bibliotecas Digitais UC Digitalis, UC Pombalina e UC Impactum, pressupõem a aceitação plena e sem reservas dos Termos e Condições de Uso destas Bibliotecas Digitais, disponíveis em https://digitalis.uc.pt/pt-pt/termos.

Conforme exposto nos referidos Termos e Condições de Uso, o descarregamento de títulos de acesso restrito requer uma licença válida de autorização devendo o utilizador aceder ao(s) documento(s) a partir de um endereço de IP da instituição detentora da supramencionada licença.

Ao utilizador é apenas permitido o descarregamento para uso pessoal, pelo que o emprego do(s) título(s) descarregado(s) para outro fim, designadamente comercial, carece de autorização do respetivo autor ou editor da obra.

Na medida em que todas as obras da UC Digitalis se encontram protegidas pelo Código do Direito de Autor e Direitos Conexos e demais legislação aplicável, toda a cópia, parcial ou total, deste documento, nos casos em que é legalmente admitida, deverá conter ou fazer-se acompanhar por este aviso.

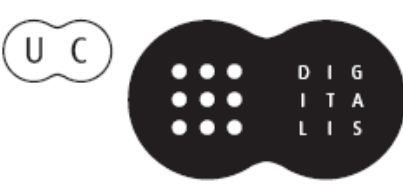


Colecção Autores Gregos e Latinos SérIe TeXtos

\section{LuCiano de Samósata}

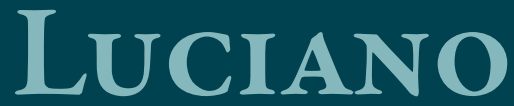

[II]

TRADUÇÃO DO GREGO, INTRODUÇÃO E NOTAS Custódio Maguejo 
Amadurecido pelas viagens e pela experiência da vida, materialmente afortunado, Luciano cedo se farta da actividade judiciária, da retórica e da sofística, para se entregar a uma actividade literária que, não sendo nova, ele, no entanto, reforma de maneira radical: trata-se do diálogo filosófico, mas agora entendido e elaborado segundo princípios originais. De facto, Luciano aligeira substancialmente o majestoso diálogo filosófico que vinha dos tempos de Platão e acrescenta-lhe um aspecto dramático, orientado no sentido da sátira - o que significa reunir no «novo género» dois géneros diferentes e até muito diversos: o diálogo filosófico e a comédia. Realmente, foram sobretudo as obras em forma de diálogo que deram fama a Luciano. É nelas que melhor se expande a sua crítica panfletária e corrosiva, que atinge, literalmente, tudo e todos: os deuses e os heróis, a religião e as religiōes, a filosofia e as suas variadíssimas seitas, a moral convencional, a sociedade e os seus pilares mais destacados, os homens e as suas vaidades, as suas superstiçóes irracionais e o aproveitamento que delas fazem os espertos... enfim, podemos dizer que em Luciano conflui o que de mais violento havia na comédia. Um certo epicurismo prático e um cinismo teórico afinam e refinam o processo. 
(Página deixada propositadamente em branco) 
(Página deixada propositadamente em branco) 


\title{
Luciano de Samósata
}

\section{Luciano}

\author{
[II]
}

Tradução do grego, introdução e notas de Custódio Magueijo

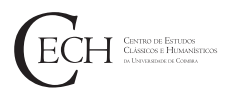


Todos os Volumes desta SÉRIE SÃo SUJeitos A ARBITRAGEM CIENTífica INDEPENDENTE.

Título $\cdot$ Luciano [II]

Traduçấo do Grego, Introdução e Notas • Custódio Magueijo

Autor • Luciano de Samósata

Série Monografias

Coordenador Científico do plano de ediçấo: Maria do Céu Filho

Comissão Edtorial

José Ribeiro Ferreira

Francisco de Oliveira

Maria de Fátima Silva

Nair Castro Soares

Diretor Técnico: Delfim Leão

\section{Obra REALIZADa No ÂMbito DaS ACTIVIDADES Da UI\&D}

Centro de Estudos Clássicos e Humanísticos

\section{EDIÇÃo}

Imprensa da Universidade de Coimbra

URL: http://www.uc.pt/imprensa_uc

E-mail: imprensauc@ci.uc.pt

Vendas online:

http://livrariadaimprensa.uc.pt

COORDENAÇÁo EDITORIAL

Imprensa da Universidade de Coimbra

CONCEPÇÃo GRÁFICA

Imprensa da Universidade de Coimbra

INFOGRAFIA

Mickael Silva

\author{
Impressấo e ACABAmento \\ www.artipol.net
}

ISBN

978-989-26-0799-3

ISBN Digital

978-989-26-0800-6

DOI

http://dx.doi.org/10.14195/978-989-26-0800-6

Depósito Legal

$353356 / 12$

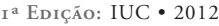

\section{(C) DEZEMBRo 2012.}

IMPRENSA dA UNIVERSIDADE de CoImbra

Classica Digitalia Vniversitatis Conimbrigensis (http://classicadigitalia.uc.pt)

Centro de Estudos Clássicos e Humanísticos da Universidade de Coimbra

Reservados todos os direitos. Nos termos legais fica expressamente proibida a reproduçáo total ou parcial por qualquer meio, em papel ou em ediçáo electrónica, sem autorizaçáo expressa dos titulares dos direitos. É desde já excepcionada a utilizaçáo em circuitos académicos fechados para apoio a leccionaçáo ou extensáo cultural por via de e-learning. 


\title{
Luciano de Samósata
}

\section{Luciano}

\author{
[II]
}

Tradução do grego, introdução e notas de Custódio Magueijo

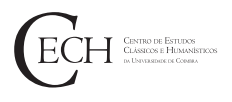


(Página deixada propositadamente em branco) 


\section{SUMÁRIO}

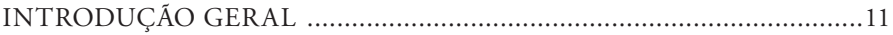

EU, LÚCIO - MEMÓRIAS DE UM BURRO …......................................17

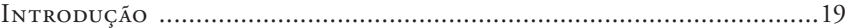

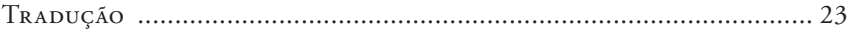

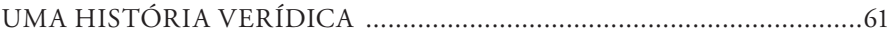

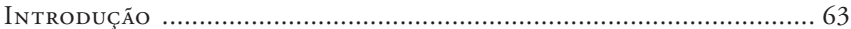

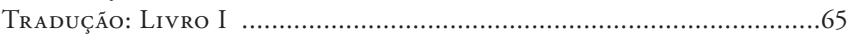

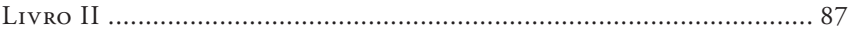

O MENTIROSO OU O INCRÉDULO ….................................................109

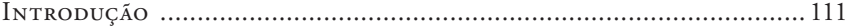

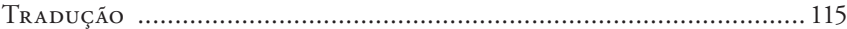

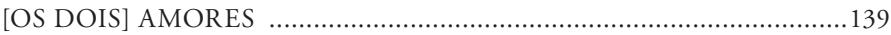

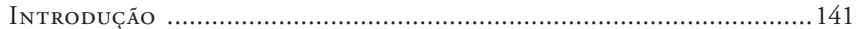

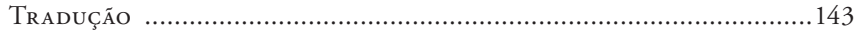

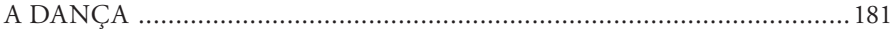

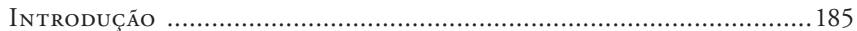

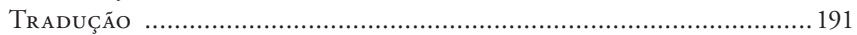

HERMOTIMO OU AS ESCOLAS FILOSÓFICAS …………………..... 223

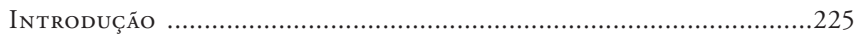

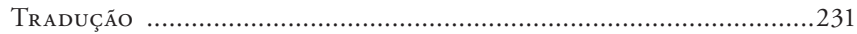


Ficha Técnica:

Autor: Luciano de Samósata

Título: Luciano (II):

- Eu, Lúcio - Memórias de um Burro

- Uma História Verídica

- O Mentiroso ou O Incrédulo

- [Os Dois] Amores

- A Dança

- Hermotimo ou As Escolas Filosóficas

Edição utilizada: A. M. Harmon, Lucian, The Loeb Classical Library: Greek authors, Harvard University Press, 1959-1961. 


\title{
Luciano
}<smiles>[AlH2]</smiles>

EU, LÚCIO - MEMÓRIAS DE UM BURRO

\author{
UMA HISTÓRIA VERÍDICA
}

O MENTIROSO OU O INCRÉDULO

[OS DOIS] AMORES

A DANÇA

HERMOTIMO OU AS ESCOLAS FILOSÓFICAS 
(Página deixada propositadamente em branco) 


\section{INTRODUÇÁO GERAL ${ }^{1}$}

Luciano nasceu em Samósata, capital do antigo reino de Comagena, situado a norte da Síria, na margem direita do Eufrates. Os primeiros imperadores romanos conservaram-lhe um certo grau de independência, mas acaba por ser incluído entre as províncias do Império Romano.

Quanto a datas de nascimento e morte, aceitemos 125-190 d. C. Seguramente, a vida literária de Luciano desenvolve-se na segunda metade do séc. II d. C., por um período de quarenta anos, durante o qual escreveu cerca de oitenta obras.

No tocante a dados biográficos, temos de contentar-nos com as informaçóes contidas no conjunto dos seus escritos. Pelo menos têm a vantagem de serem de primeira máo. E se a nossa curiosidade mais "superficial» gostaria de saber muitas outras coisas sobre a sua vida, a verdade é que o essencial do homem está nítida e magnificamente retratado na obra.

De entre as obras mais importantes do ponto de vista autobiográfico, salienta-se a intitulada $O$ Sonho (ou Vida de Luciano). Imediatamente se conclui tratar-se dum trabalho da meia-idade, que mais abaixo resumimos.

Após uma peregrinação de vários anos por terras da Grécia, da Itália e da Gália, onde conseguira assinalável êxito e náo menos importante pecúlio, Luciano regressa (por volta de 162-163) à sua cidade natal, que o havia visto partir pobre e quase anónimo, e agora se orgulhava do prestígio que lhe era transmitido pelo próprio êxito dum filho seu. É então que Luciano, perante os seus concidadãos, traça uma retrospectiva autobiográfica, da qual mencionamos os passos mais salientes.

Chegado ao termo da escolaridade elementar, adolescente de quinze anos, o pai aconselha-se com familiares e amigos sobre o futuro do moço.

"A maioria opinou que a carreira das letras requeria muito esforço, longo tempo, razoável despesa e uma sorte brilhante. Ora, a nossa fortuna era limitada, pelo que, a breve trecho, precisariamos de alguma ajuda.

${ }^{1}$ Esta «Introdução geral» é, na verdade, reproduzida de outras que escrevi a propósito de diversas obras de Luciano. Não se pode exigir que, para cada uma das cerca de oitenta, tivesse de inventar uma biografia formalmente diferente de Luciano. No entanto, a parte final, relativa a cada obra em particular, é redigida especialmente para esta edição. 
Se, pelo contrário, eu aprendesse um ofício, começaria imediatamente a retirar dai um ordenado minimo, que me permitiria, naquela idade, deixar de ser um encargo familiar, e até mesmo, algum tempo depois, dar satisfação a meu pai com o dinheiro que traria para casa." (\$ 1)

Restava escolher o ofício. Discutidas as várias opinióes, foi decidido entregar o rapaz aos cuidados dum tio materno, presente na reuniấo, e que era um excelente escultor. Além deste factor de ordem familiar, pesou ainda o facto de o moço, nos seus tempos livres, gostar de se entreter a modelar, em cera, bois, cavalos e figuras humanas, "tudo muito bem parecido, na opinião de meu pai». Por essa actividade "plástica» (é palavra sua), que não raro o desviava dos deveres escolares, "chegava mesmo a apanhar pancada dos professores, mas isso agora transformava-se em elogio à minha vocação». (\$2)

Chegado o grande dia, é com certa emoção que o jovem Luciano se dirige à oficina do tio, a fim de iniciar a sua nova vida. De resto, via no ofício de escultor uma espécie de brincadeira de certo modo agradável, e até uma forma de se distinguir perante os amigos, quando estes o vissem esculpir figuras de deuses e estatuetas. Todavia, e contrariamente às suas esperanças, o começo foi desastroso. O tio póe-lhe na mão um escopro e manda-o desbastar uma placa de mármore, a fim de adiantar trabalho ("O começar é meio caminho andado"). Ora... uma pancada um pouco mais forte, e eis que se quebra a placa... donde uma monumental sova de correia, que só a fuga consegue interromper. Corre para casa em tal estado, que a mãe não pode deixar de censurar asperamente a brutalidade do irmáo. Entretanto, aproxima-se a noite, e o moço, ainda choroso, dolorido e revoltado, foi deitar-se. As fortes emoçóes do dia tiveram como resultado um sonho - donde o título da obra. (\$\$ 3-4)

Até aqui, Luciano fornece-nos dados objectivos, que nos permitem formar uma ideia suficientemente precisa sobre si próprio e sobre a situação e ambiente familiares. Quanto ao sonho, se nada nos permite duvidar da sua ocorrência, a verdade é que se trata, antes de mais, duma elaboração retórica, elemento tantas vezes utilizado na literatura, mas nem por isso menos significativo do ponto de vista autobiográfico. De facto, Luciano serve-se deste processo para revelar aos seus ouvintes náo tanto o que se terá passado nessa noite, mas principalmente a volta que a vida dera, a partir duma situação que, em princípio, teria uma sequência bem diferente. 
Assim, e com uma nitidez - segundo afirma - «em nada diferente da realidade», aparecem-lhe duas mulheres, que, energicamente e até com grande violência, disputam a posse do moço, que passa duma para a outra, e volta à primeira... enfim, "pouco faltou para que me despedaçassem».

Uma delas era a Escultura (Hermoglyphikê), «com o (tipico) aspecto de operário, viril, de cabeleira sórdida, mãos cheias de calos, manto subido e coberto de pó, como meu tio quando estava a polir as pedras». A outra era a Cultura (Paideia), "de fisionomia extremamente agradável, pose digna e manto traçado a preceito». (\$\$ 5-6).

Seguem-se os discursos de cada uma das personagens, que fazem lembrar o agôn ("luta», "disputa») das Nuvens de Aristófanes, travado entre a Tese Justa e a Tese Injusta.

A fala da Escultura, mais curta (\$\$ 7-8), contém, no entanto, elementos biográficos (explícitos e implícitos) de certa importância. Começa por se referir à tradição profissional da família do jovem, cujo avô materno e dois tios, também maternos, eram escultores de mérito. A seguir, enumera as vantagens da profissão: comida farta, ombros fortes e, sobretudo, uma vida particular ao abrigo de invejas e intrigas, em vez de (como, de resto, veio a suceder - daí também o valor biográfico da informação) viagens por países longínquos, afastado da pátria e dos amigos. De resto, a História está cheia de exemplos de grandes escultores (Fídias, Policlito, Míron, Praxíteles), cujo nome é imortal e que são reverenciados juntamente com as estátuas dos deuses por eles criadas.

O discurso da Cultura ( $\$ \$ 9-13)$ possui todos os ingredientes necessários à vitória (além das informaçōes biográficas que recolhemos das suas "profecias»... já realizadas). Vejamos alguns passos.

"Meu filho: eu sou a Cultura, entidade que já te é familiar e conhecida, muito embora ainda não me tenhas experimentado completamente." "Quanto aos grandes benefícios que te proporcionará o oficio de escultor, já esta aqui os enumerou: não passarás dum operário que mata o corpo com trabalho e nele depóes toda a esperança da sua vida, votado ao anonimato e ganhando um salário magro e vil, de baixo nivel intelectual, socialmente isolado, incapaz de defender os amigos ou de impor respeito aos inimigos, de fazer inveja aos teus concidadãos. Apenas isto: um operário, um de entre a turba, prostrado aos pés dos poderosos, 
servidor humilde dos bem-falantes, levando uma vida de lebre, presa do mais forte. E mesmo que viesses a ser um outro Fídias ou um Policlito, mesmo que criasses muitas obras-primas, seria apenas a obra de arte aquilo que toda a gente louvaria, e ninguém de bom senso, entre os que a contemplassem, ambicionaria ser como tu. Sim: por muito hábil que sejas, não passarás dum artesão, dum trabalhador manual.»

Se, porém, me deres ouvidos, antes de mais revelar-te-ei as numerosas obras dos antigos, falar-te-ei dos seus feitos admiráveis e dos seus escritos, tornar-te-ei um perito em, por assim dizer, todas as ciências. E quanto ao teu espírito - que é, afinal, o que mais importa -, exorná-lo-ei com as mais variadas e belas virtudes: sabedoria, justiça, piedade, doçura, benevolência, inteligência, fortaleza, amor do Belo e paixáo do Sublime. Sim, que tais virtudes é que constituem verdadeiramente as incorruptíveis jóias da alma...

"Tu, agora pobre, tu, ofilho do Zé-Ninguém, tu, que ainda há pouco havias enveredado por um ofício tão ignóbil, dentro em breve serás admirado e invejado por toda a gente, cumulado de honrarias e louvores, ilustre por tua alta formação, estimado das elites de sangue e de dinheiro; usarás um traje como este (e apontava-me o seu, que era realmente magnífico) e gozarás de merecido prestígio e distinção. $E$ sempre que saias da tua terra, vás para onde fores, não serás, lá fora, um obscuro desconhecido: impor-te-ei tal marca, que, ao ver-te, um qualquer, dando de cotovelo ao vizinho, apontar-te-á com o dedo, dizendo: "É este, o tal"..."

O final do discurso ( $\$ 13)$ constitui um autêntico «fecho» elaborado segundo as leis da retórica. Depois de, no parágrafo anterior, ter mencionado os exemplos de Demóstenes (filho dum fabricante de armas), de Ésquines (cuja mãe era tocadora de pandeireta) e de Sócrates (filho de escultor), lança o ataque final:

"Caso desprezes o exemplo de tão ilustres homens, seus feitos gloriosos e escritos veneráveis, presença imponente, honra, glória e louvores, supremacia, poder e dignidades, fama literária e o apreço devido à inteligência - então passarás a usar uma túnica reles e encardida, ganharás um aspecto servil, agarrado a alavancas, cinzéis, escoprose goivas, completamente inclinado sobre o trabalho, rastejante e rasteiro, humilde em todas as acepçóes da palavra, sem nunca levantar a cabeça, sem um único pensamento digno dum homem livre, mas antes continuamente preocupado com a ideia de a obra te sair harmoniosa e apresentável - enquanto a respeito de ti próprio, da maneira de te 
tornares harmonioso e bem dotado, não te importas absolutamente nada; pelo contrário, ficarás mais vil que as mesma pedras.»

É pena que esta autobiografia não tivesse sido escrita uns vinte (ou trinta) anos mais tarde. Em todo o caso, Luciano, noutras obras, fornece-nos mais algumas indicaçóes.

Assim, pela Dupla Acusação (\$27), escrita pouco depois do Sonho, sabemos que Luciano, entregue de alma e coração à retórica e à sofística, iniciara a sua actividade de advogado em várias cidades da Ásia Menor (Segundo a Suda, "começou por ser advogado em Antioquia»). Da Ásia Menor, passa para a Grécia, e daí para a Itália, mas é sobretudo na Gália que obtém glória e fortuna.

Uma dúzia de anos depois de ter saído da sua terra natal, regressa a casa, mas por pouco tempo. Decide fixar-se com a família em Atenas, onde permanece por cerca de vinte anos (c. 165-185 d. C.). A Dupla Acusação deve datar dos primeiros anos da sua estada na capital da cultura. Amadurecido pelas viagens e pela experiência da vida, materialmente afortunado, este homem de cerca de quarenta anos (v. \$32) cedo se farta da actividade judiciária, da retórica e da sofística, para se entregar a uma actividade literária que, não sendo nova, ele, no entanto, reforma de maneira radical: trata-se do diálogo filosófico, mas agora entendido e elaborado segundo princípios originais. De facto, Luciano aligeira substancialmente o majestoso diálogo filosófico que vinha dos tempos de Platão, e acrescenta-lhe um aspecto dramático, orientado no sentido da sátira - o que significa reunir no "novo género" dois géneros diferentes e até muito diversos: o diálogo filosófico e a comédia. E realmente foram sobretudo as obras em forma de diálogo que deram fama a Luciano. É nelas que melhor se expande a sua crítica panfletária e corrosiva, que atinge - literalmente - tudo e todos: os deuses e os heróis, a religião e as religiōes, a filosofia e as suas variadíssimas seitas, a moral convencional, a sociedade e os seus pilares mais destacados, os homens e as suas vaidades, as sua superstições irracionais e o aproveitamento que delas fazem os espertos... enfim, podemos dizer que em Luciano conflui o que de mais violento havia na comédia. Um certo epicurismo prático e um cinismo teórico afinam e refinam o processo.

Aos quarenta e poucos anos, Luciano adopta uma atitude fundamentalmente céptica, que, sobretudo, se insurge contra todo 
o dogmatismo metafísico e filosófico em geral. A este respeito, recomenda-se vivamente a leitura do Hermotimo (ou As Seitas ${ }^{2}$ ), obra dum niilismo verdadeiramente perturbador: dada a variedade das correntes filosóficas, e ainda devido ao tempo e esforço necessários a uma séria apreciação de cada uma, o homem, por mais que faça, não pode atingir a verdade. Basta citar uma frase, que, não sendo de modo nenhum a mais importante deste diálogo, é, no entanto, verdadeiramente lapidar: "As pessoas que se dedicam à filosofia lutam pela sombra dum burro» (\$71). E, já agora, aqui fica o fecho, em que Hermotimo, finalmente convencido pelos argumentos de Licino (ou seja, Luciano), afirma: "Quanto aos filósofos, se por acaso, e apesar das minhas precauçóes, topar com algum no meu caminho, evitá-lo-ei, fugirei dele como dum cão raivoso». (\$ 86)

Cerca de vinte anos depois de chegar a Atenas, Luciano decide recomeçar a viajar, mas nada será como antigamente: já na recta final da existência, talvez em situação financeira menos próspera, e sem dúvida desiludido com o deteriorado clima cultural de Atenas, fixa-se no Egipto, onde aceita (ou consegue?) um lugar de funcionário público, aliás compatível com a sua formação e importância social. Ele próprio nos informa (Apologia dos Assalariados, $\$ 12$ ) de que a sua situação não se compara à dos miseráveis funcionários (por exemplo: professores), que afinal não passam de escravos. E continua: " $A$ minha condiçáo, meu caro amigo ${ }^{3}$, é completamente diferente. Na vida privada, conservei toda a minha liberdade; publicamente, exerço uma porçāo da autoridade suprema, que administro em conjunto com o procurador ... Tenho sob a minha responsabilidade uma parte considerável da provincia do Egipto, cabe-me instruir os processos, determinar a ordem pela qual devem dar entrada, manter em dia os registos exactos de tudo o que se diz e faz, ... executar integralmente os decretos do Imperador ... E além do mais, o meu vencimento náo se parece nada com o dum simples particular, mas é digno dum rei, e o seu montante, longe de ser módico, ascende a uma soma considerável. A tudo isto acrescenta o facto de eu não me alimentar de esperanças modestas, pois é possivel que ainda obtenha a titulo pleno a prefeitura ou qualquer outra função verdadeiramente real.»

Esperanças nada modestas, provavelmente bem fundadas... Só que, por motivos que ignoramos, tudo se desfez em vento.

2 "Clássicos Inquérito», no 16.

${ }^{3}$ Esta obra, de forma epistolar, é dirigida a um tal Sabino, amigo de Luciano. 
EU, LÚCIO - MEMÓRIAS DE UM BURRO 
(Página deixada propositadamente em branco) 


\section{INTRODUÇẤO}

No conjunto da produçáo literária de Luciano, destacam-se, por contraste, algumas obras de fantasia, de ficção, de imaginaçáo à solta. E mesmo que nos garantam (nomeadamente o próprio Luciano) que por detrás da fantasia há outro «texto", a verdade é que a força narrativa é de tal ordem, que o leitor moderno náo pode senão deixar-se penetrar da espontaneidade e da naturalidade da história. É que, como contador de histórias, Luciano é um mestre muito especial.

Além, entre outras obras, do Icaromenipo e de Uma História Verídica $^{4}$, cabe naturalmente referir aqui, com algum desenvolvimento, Lúcio ou O Burro (assim mesmo, em alternativa, como a obra é muitas vezes citada desde a Antiguidade). No entanto, entendi, por motivos que o especialista talvez reprove (pura subjectividade), alterar o título tradicional. Em atenção ao leitor moderno e, em princípio, leigo em questôes de filologia clássica, optei por um título mais sugestivo: $E u$, Lúcio - Memórias de um Burro. Quer dizer: trata-se duma história contada na $1^{a}$ pessoa, por um tal Lúcio, que, durante certo período da sua vida, esteve metamorfoseado em burro.

A mitologia grega está cheia de casos de pessoas transformadas em animais, em plantas, em pedras..., quer por directa intervençáo divina, quer por artes mágicas praticadas por seres humanos possuidores de certos conhecimentos que lhes facultam uma relação com o sobrenatural. Basta recordar Circe, a divina feiticeira, isto é, deusa e maga, que transforma em porcos os companheiros de Ulisses.

É claro que um homem como Luciano não acredita em tais patranhas, que repetidamente desmascara. E embora a sua forma habitual de combater a crendice e a superstição seja por via da sátira, algumas vezes é bastante mais subtil, ao elaborar (ou aproveitar) histórias ao gosto popular, aparentemente com a intenção exclusiva de divertir os leitores. O crítico, certamente, exercerá a chamada "segunda leitura», para além do texto. Quem mais se diverte, porém, é o leitor descuidado, que procura isso mesmo: divertimento e diversáo. E daí, quem sabe..., talvez o puro divertimento divirta, ou distraia, a ponto de constituir precisamente o objecto da "segunda leitura», aquela que

\footnotetext{
${ }^{4}$ Clássicos Inquérito, no 13.
} 
aponta para o sentido oculto... mas, afinal, tão óbvio: não é para acreditar, mas para divertir.

O gosto dos contemporâneos de Luciano por este género de literatura merece uma explicação.

$\mathrm{Na}$ época de Luciano (e antes... e depois), assiste-se a uma autêntica epidemia do irracional: multidóes ignorantes aderem às variadíssimas religióes de mistério e salvação que proliferavam no Oriente e que, a partir daí, numa onda gigantesca, impregnavam todas as províncias do Império Romano.

A par do misticismo religioso (e até conjugado com ele), o irracional assume também a forma de superstição e de práticas de magia. As feiticeiras da Tessália, essas, levavam a palma a todas as outras.

Esta história do homem metamorfoseado em burro era bem conhecida desde antes do tempo de Luciano. Numa forma mais complexa, com outras histórias dentro da história principal, chegou até nós uma "versão" latina: O Burro de Oiro, ou Metamorfoses, de Apuleio ${ }^{5}$. Além dessa, temos notícia duma outra, com o título (em grego) de Metamorfoses, atribuída a um tal Lúcio de Patras por Fócio, Patriarca de Constantinopla (séc. IX d. C.), que declara tê-la lido e admirado nela um estilo claro, puro e atraente. Por um momento, Fócio admite que Lúcio de Patras se tenha inspirado em Luciano, mas acaba por se inclinar francamente para a posição inversa, ou seja, que terá sido Luciano quem se inspirou em Lúcio de Patras, eliminando certos episódios e condensando num só livro aquilo que Lúcio de Patras havia desenvolvido em vários. Diz-nos o mesmo Fócio que, enquanto Lúcio de Patras escreveu uma história na qual acreditava, Luciano satiriza a superstição dos seus contemporâneos - opinião de quem, claramente, leu ambas as obras, pelo que não temos razão para duvidar da sua existência. É pena (exasperante!) que se tenha perdido uma obra que... quase havia chegado aos séculos de grande azáfama dos copistas (e daí ao Renascimento, à imprensa, aos tempos modernos...).

Admito, pois (sem entrarmos numa polémica sem fim e sem glória), que Lúcio de Patras (ou, pelo menos, a obra que lhe é atribuída por Fócio) é a fonte simultaneamente de Apuleio e de Luciano. A comparação entre as duas obras talvez seja significativa: O Burro de Oiro (ou Metamorfoses) de Apuleio bem

${ }^{5}$ Publicado com o título $O$ Asno de Oiro pelas Publicaçóes Europa-América. 
pode constituir uma versão mais chegada ao original, com a já referida variedade de histórias, mas também na linha dum certo respeito pelas religióes de mistério e de iniciação, ao passo que $O$ Burro de Luciano seria a sua versão resumida, liberta de histórias sem ligação com a história principal e, sobretudo, como diz Fócio, escrita com intuito crítico, espírito esse que seria responsável, nomeadamente, pela diferente conclusão relativamente à versão de Apuleio (e certamente também de Lúcio de Patras).

Apesar desta dependência (cujo grau não podemos avaliar para além da informação de Fócio), Luciano deve ter encontrado a sua margem de originalidade, produzindo (ou reproduzindo, mas com um génio próprio e inalienável) uma história monotemática, clara, divertida, saborosa e impregnada daquele picante erótico que os Antigos cultivavam com tanta naturalidade, sem qualquer sombra de pecado: o prazer do corpo era, também, um prazer para a alma. O célebre mens sana in corpore sano náo incluía a castração, nem do corpo nem da alma.

NOTA - Alguns críticos modernos, fundamentados em aspectos linguísticos e estilísticos próprios do grego vulgar e popular, rejeitam a autoria de Luciano e atribuem a obra a um seu imitador. Outros, porém, contrapóem-lhes uma colecção de traços linguísticos e estilísticos próprios de Luciano.

Por minha parte, limito-me a fazer duas observaçóes:

$1^{\mathrm{a}}$ - Luciano, ao escrever uma história já bem conhecida, divulgada e vulgarizada entre as massas populares, poderia muito bem optar por um estilo predominantemente oral e próximo da maioria dos seus imaginados leitores (e até ouvintes). Ou náo seria Luciano capaz de tanto e homem para tal?

$2^{\mathrm{a}}$ - Este problema de autoria (como tantos outros...) apenas foi suscitado nos tempos modernos, e resulta - cuido eu - não só dum excesso de criticismo, mas também duma 
certa dose de preconceito sobre o que deve ser o estilo de cada autor, e tudo isto relacionado com o que os críticos consideram o bom e o mau, ou menos bom, uso da língua.

Enfim, para levantarem o problema da autoria, que náo existia antes, os críticos terão de encontrar dados mais seguros ou indícios mais fortes. 


\section{EU, LÚCIO - MEMÓRIAS DE UM BURRO}

1. Uma vez, ia eu a caminho da Tessália, onde, em nome de meu pai, devia celebrar um contrato com um homem daquela regiáo. Um cavalo transportava-me a mim e à bagagem, e fazia-me acompanhar de um único criado.

Caminhando, portanto, pela dita estrada, eis que a certa altura calhou encontrarmos outros viajantes, que se dirigiam para Hípate, cidade da Tessália, donde eram naturais. Passámos a tomar as refeiçóes em comum ${ }^{6}$, assim abreviando aquela viagem penosa... até que, já perto da cidade, perguntei aos tessálios se por acaso conheciam um sujeito que residia em Hípate, Hiparco de seu nome; era portador de uma carta da minha terra para ele, de recomendação para que me hospedasse em sua casa. Eles responderam que sim, que conheciam esse tal Hiparco, em que zona da cidade morava, que possuía um fortuna muito razoável, e que sustentava, ao todo, uma única criada, mais a mulher; que, de facto, era terrivelmente avarento.

Chegados às portas da cidade, deparámos com uma horta e, dentro dela, uma casita jeitosa, onde morava Hiparco.

2. Então os meus companheiros cumprimentaram-me e foram andando; e eu dirigi-me à porta e bati. Foi a muito custo, e com todo o vagar, que uma mulher me respondeu e de seguida assomou. Perguntei-lhe se Hiparco estava em casa. «Está sim» - disse ela - «Mas quem és tu? Que pretendes dele?» de Patras.»

- Venho entregar-lhe uma carta da parte do sofista Decriano,

— «Espera aí» - disse ela. Fechou a porta e foi lá dentro. Daí a algum tempo, voltou e mandou-nos ${ }^{7}$ entrar. Assim fiz e, uma vez lá dentro, cumprimentei o dono da casa e entreguei-lhe a carta. Ora, por acaso o homem ia começar a cear, reclinado ${ }^{8}$ num leito pequeno e estreito; junto dele estava sentada9 uma mulher, e, em frente, via-se uma mesa vazia. Depois de ler a carta, disse: «Sim

${ }^{6}$ Literalmente: «... a partilhar o sal» - expressão idiomática.

7 «mandou-nos»: já é possível, naquela época, o uso do chamado «plural majestático» = «mandou-me», como se vê pelo seguimento: "Assim fiz...»

${ }^{8}$ Os antigos comiam na posição de reclinados num leito baixo, e não sentados.

${ }^{9}$ A mulher estava sentada, precisamente por só haver um leito, o qual, no entanto, apesar de estreito, irá acolher também o hóspede. 
senhor: então o meu querido Decriano, o mais notável dos gregos, faz muitíssimo bem em encaminhar para minha casa, com toda a confiança, os seus amigos. A minha casita, Lúcio, estás vendo como é pequena, mas sempre bem disposta a receber um hóspede; tu, porém, torná-la-ás uma grande casa, desde que sejas um hóspede pouco exigente.» $\mathrm{E}$ chama a moçoila: «Palestra ${ }^{10}$, prepara o outro quarto, pega na bagagem e arruma-a; depois, trata de conduzir o nosso hóspede ao banho, que acaba de fazer uma viagem bem longa.»

3. A estas palavras, a mocetona, Palestra, indica-me o caminho e mostra-me um belíssimo apartamento. "Tu»disse - «dormirás nesta cama; e para o teu criado colocarei acolá um divẫ ${ }^{11}$ e ponho-lhe também um travesseiro.» Assim falou, e nós ${ }^{12}$, pela nossa parte, dirigimo-nos ao banho, náo sem que antes lhe tivéssemos dado com que comprar uma ração para o cavalo; e a rapariga, por seu lado, pegou na nossa bagagem, trouxe-a para dentro e arrumou-a. Terminado o banho, regressámos imediatamente à sala, onde Hiparco me recebeu, convidando-me a reclinar-me a seu lado. A ceia náo foi mesmo nada frugal, e o vinho era macio e velho. A seguir à ceia, houve um período de bebida e conversa, como é de norma quando há visitas de fora para o jantar. Então, depois de passarmos o serăo ${ }^{13}$ a beber, fomos deitar-nos. No dia seguinte, Hiparco perguntou-me para onde ia agora de viagem, e se ficaria lá por fora ${ }^{14}$ todo o tempo. "Parto para Larissa»respondi-, mas conto ficar ainda por cá uns três a cinco dias.»

4. Mas isso [da viagem a Larissa] era fingimento: na verdade, o que eu ardentemente desejava era permanecer ali [em Hípate]

${ }^{10} \mathrm{O}$ nome da criada, Palestra, significa «luta», e vai ser, adiante, motivo para uma picante cena de luta... amorosa. Este é um dos casos em que a traduçáo fica, por força, aquém do original.

${ }^{11}$ Devia tratar-se de uma cama provisória, talvez uma simples enxerga es-tendida no chão, como se depreende pelo verbo usado mais adiante $(\$ 7)$.

12 «nós... dirigimo-nos... tivéssemos...»: plural majestático, como $\$ 2$ (v. nota).

${ }^{13} \mathrm{O}$ gr. hespéra (cf. lat. uespera) significa o fim da tarde e parte da noite.

14 «lá por fora»: no original, poderia entender-se, literalmente, "cá», «nesta terra», ou "lá», "naquela terra». O $1^{\circ}$ sentido (donde deriva a interpretação da ed. "Loeb", é de rejeitar, a menos que, em vez de "...e se ficaria», traduzíssemos por "...ou se ficaria» (o que o texto não permite). $\mathrm{O}$ passo mereceria tratamento desenvolvido, que náo cabe nesta nota. 
e encontrar alguma dessas mulheres peritas em artes mágicas, e presenciar algo de incrível, como, por exemplo, uma pessoa a voar ou a transformar-se em pedra. Assim, todo entregue ao desejo ardente de assistir a um desses fenómenos, comecei a deambular pela cidade. Não sabia por onde começar a pesquisa, mas, de qualquer modo, continuei a deambulação. Eis senáo quando, vejo vir na minha direcção uma mulher ainda nova e (tanto quanto se podia julgar exteriormente) de boa posição social: vestes garridas, uma chusma de criados e jóias com fartura. Já mais de perto, a mulher cumprimenta-me, e eu retribuo-lhe da mesma forma. E diz ela: «Eu sou Abreia (certamente que tens ouvido falar duma amiga de tua mãe com esse nome); amo-vos a vós, filhos ${ }^{15}$ dessa minha amiga, como àqueles que eu própria dei à luz. Portanto, meu filho, porque não vens hospedar-te em minha casa?»

«É muita amabilidade da tua parte» - respondi -, «mas envergonho-me de abandonar a casa dum amigo, sem ter a mínima razáo de queixa dele. No entanto, minha querida amiga, em pensamento estou hospedado em tua casa.»

— «Mas afinal» - perguntou ela -, "onde é que estás hospedado?»

— «Em casa de Hiparco.»

— «Esse avarento?» - perguntou.

— «Ó mãezinha» - respondi -, «não digas uma coisa dessas, pois ele tem sido magnífico e muito generoso comigo, a ponto mesmo de poder-se acusá-lo de excesso de luxo.»

Então ela, sorrindo, pega-me pela máo, leva-me mais adiante e diz-me: "Tem cuidado com a mulher de Hiparco: toda a prudência é pouca, pois ela é uma feiticeira terrível, lasciva, e que deita o olho ${ }^{16}$ a todos os jovens; e se algum não se lhe submete, ela vinga-se por meio das suas artes: a muitos, já os tem transformado em animais, e a outros mata-os pura e simplesmente. Ora tu, meu filho, és jovem e belo, o bastante para agradar imediatamente a uma mulher; além disso, és forasteiro - factor para que ninguém se preocupe [contigo].»

5. Então eu, informado de que aquilo que há muito procurava estava lá em casa, à mão, perdi todo o interesse pela mulher. E mal, enfim, me despedi, dirigi-me a casa; no caminho, ia dizendo de

${ }^{15}$ Referência a um irmão de Lúcio, de nome Gaio, mencionado no $\$ 55$.

16 «deita o olho»: é possível que a expressão já contenha, também, um certo senti mágico, de que resulta o «mau olhado». 
mim para comigo: «Vamos, meu velho! Ora tu, que não páras de manifestar o desejo de presenciar um destes fenómenos estranhos, acorda, trata de arranjar um plano artificioso para conseguires o que tanto desejas: "despe-te"17 e atira-te à criada... à... Palestra (pois, quanto à mulher do teu hospedeiro e amigo, há que manter as distâncias); e se te "enrolares" com ela, se praticares umas "jogadas", enfim, se a filares com um "golpe de cintura", fica certo de que será fácil saber o que pretendes: sim, que os criados é que conhecem as virtudes e os podres [dos seus amos].»

Assim falando comigo mesmo, entrei em casa. Não encontrei lá nem Hiparco nem sua mulher, mas apenas Palestra, que estava junto à lareira a preparar a ceia para nós.

6. Então eu atraco-me logo a ela e digo: «Ó Palestra, minha linda, com que admirável cadência bandeias e remexes ao mesmo tempo as nádegas e a panela! E essa cintura, com que delicadeza se move! Feliz daquela que "molhar a sopa" nessa coisa ${ }^{18}$."

Mas ela, que era realmente uma garota muito viva e engraçada ${ }^{19}$, respondeu: «Meu menino, se acaso tens um pouco de bom senso e amor à vida, é melhor afastares-te, pois esta "coisa" ${ }^{20}$ está em brasa, que até fumega: bastaria tocar-lhe, para apanhares uma queimadura tão forte, que ficarias logo aqui estendido; e é que ninguém, nem mesmo o divino médico ${ }^{21}$, te poderia curar... a náo ser eu, que te provoquei a queimadura; o mais estranho, porém, é que eu própria te farei desejar cada vez mais; e tu, por muito saciado que estejas, continuarás sob o domínio permanente da dor causada pelo meu "tratamento", de tal forma que até poderiam apedrejar-te, que não conseguirias abstrair-te do doce sofrimento... Mas... porque estás a rir? Pois [fica sabendo que] tens na tua frente uma autêntica cozinheira de carne humana. Sim, que eu não preparo apenas a comida trivial, mas também sei, no que toca a "esta", muito melhor,

17 «despe-te...: todo o passo está imbuído da linguagem da luta, metaforicamente aplicada à "luta erótica». Cf. port. arregaçar as mangas.

18 "molhar a sopa nessa coisa»: linguagem erótico-gastronómica.

O texto é propositadamente ambíguo.

19 "engraçada»: como em port., significa «bonita» e "cheia de humor».

20 "esta coisa», i. é, o cozinhado, mas também, em sentido sexual, «a tal coisa» feminina.

${ }^{21}$ "o divino médico»: Asclépio ou Esculápio. 
que é o homem, degolar, esfolar e desmanchar ${ }^{22}$; sinto mesmo um prazer especial em lhe manipular as vísceras e o coração.»

«É bem verdade o que dizes» - respondi -. «Realmente, mesmo estando eu à distância, sem contacto contigo, infligiste-me, não uma queimadura, mas, por Zeus!, um incêndio geral: através dos meus olhos, lançaste o teu fogo invisível para dentro das minhas entranhas, que ficaram estorricadas... mas sem que isso me causasse mal algum. Portanto, pelos deuses!, trata-me com essas amargas e doces mezinhas de que falas; e já "degolado" ${ }^{33}$ como estou, pega em mim e "esfola-me" da maneira que entenderes."

A estas minhas palavras, a rapariga deu uma gargalhada sonora e deliciosa, e, daí em diante, já era toda minha. Combinou-se então que, mal deixasse os patrôes na cama, viria ter comigo ao meu quarto e passaria lá a noite.

7. Quando, enfim, Hiparco chegou, tomámos banho e fomos cear; depois, conversámos longamente e bebemos em quantidade. A certa altura, pretextando estar com sono, levanto-me e, de facto, dirigi-me ao local onde estava alojado. Aí, estava tudo devidamente preparado: da parte de fora ${ }^{24}$, tinham estendido uma enxerga ${ }^{25}$ para o meu criado; e junto da minha cama estava uma mesa com uma taça; ao lado, havia vinho, e também água fria e quente, pronta a servir. Tudo isto era obra de Palestra. Por sobre as colchas, tinham espalhado uma grande quantidade de rosas, umas no seu estado natural, outras desfolhadas, e outras entrelaçadas em coroa. Então eu, vendo composta a "sala do banquete", fiquei à espera do... "conviva"»"

8. Assim que deixou a patroa deitada ${ }^{27}$, a rapariga apressou-se a vir ter comigo. Foi uma alegria, nós a dedicarmos um ao

${ }^{22}$ Aqui, e no resto da frase, o Autor envereda pela metáfora ligada ao abate e preparação de... reses.

${ }^{23}$ Por artes de metáfora, há aqui uma clara conotação erótica.

${ }^{24} \mathrm{O}$ criado devia dormir em local provisório, espécie de corredor.

${ }^{25} \mathrm{O}$ verbo simples subentende como complemento algo que se estende no chão: um tapete, uma enxerga...

26 "sala do banquete» e "conviva» são, em grego, palavras da mesma família, literalmente "sala do beberete» (ou «de convívio») e "companheiro de bebi-da» (ou "conviva», jogo de palavras que até poderíamos traduzir à letra. De toda a maneira, acresce uma conotação erótica derivada do contexto.

${ }^{27}$ Pela letra do texto grego, parece que a criada só «acomodava» a patroa, ao passo que o patrão dormiria noutra sala, sem precisar de criados que o ajudassem. 
outro vinho e beijos. Já bem atestados de bebida para toda a noite, diz-me Palestra: «Meu menino, há uma coisa que deves ter sempre em mente: que calhaste com uma... Palestra ${ }^{28}$. Pois bem: agora há que demonstrar se és um desses jovens rápidos e se conheces muitos golpes de... "palestra"."

— "Pois olha que não me verás esquivar-me a esse exame. Ora despe-te lá e passemos então à... "palestra"”

— «Nesse caso» - disse ela -, "trata de prestar a tua prova conforme eu pretendo. Assim: eu, à moda dos professores e treinadores, escolho e vou dizendo o nome dos golpes que pretendo; e tu prepara-te para obedecer e executar tudo o que te for pedido.»

— «Pois vai dando as tuas ordens» - respondi -, «e verifica com que prontidão, delicadeza e vigor eu executo esses golpes.»

9. Então ela tirou o vestido, pôs-se toda nua e começou imediatamente a dar ordens: «Meu borrachinho, despe-te e perfuma-te com esta loção e abraça a tua antagonista; agora puxa-a pelas duas pernas ${ }^{29}$ e deita-a de $\operatorname{costas}^{30}$; a seguir, e por cima dela, mete-lhe as pernas por entre as coxas, afasta-as ${ }^{31}$, mantém as tuas pernas elevadas e esticadas; depois, deixa-as descair e, com firmeza, cola-te a ela, penetra, ataca, avança, entra logo a matar, à queima-roupa, até que ela fique derreada. Força nesses rins! Seguidamente, dá-lhe uma "esfrega" na horizontal, espicaça-lhe as virilhas, avança até ao "muro" ${ }^{2}$; depois é continuar a bater, $\mathrm{E}$ assim que a vires derreada, monta-a, dá um nó à cintura e mantém-na assim; sobretudo, faz por não ter pressa, aguenta um pouco, acerta o passo com ela. E agora, descansar!»

10. Então eu, que havia executado facilmente todas as ordens, assim que a sessão terminou, volto-me para Palestra e digo, sorrindo: "Ó mestra, já vês com que prontidão e docilidade me desempenhei dos exercícios; no entanto, pensa lá bem se

${ }^{28}$ Náo esquecer o significado do nome Palestra: "luta", sentido que, de resto, vem logo a seguir. E de facto, começa aqui uma cena de luta... erótica, pontuada de vocabulário técnico, que para o leitor antigo era de compreensão imediata.

29 Trata-se de, em termos de luta, "passar uma rasteira».

30 É o chamado "assentamento de espáduas».

31 «afasta-as», i. é, "... as tuas pernas»: este afastamento obriga as coxas da antagonista a abrir também.

32 o "muro" refere-se, naturalmente, não só ao limite do terreno da luta, como, em sentido figurado, ao fundo do útero. 
não dirigiste incorrectamente os exercícios, pois mandavas-me fazer um logo a seguir ao outro.»

E ela, dando-me um tabefe, disse: «Mas que aluno tão tagarela que eu arranjei; vê lá mas é não apanhes mais pancada, caso executes golpes diferentes dos que te são ordenados.»

E dizendo isto, levanta-se, compóe-se e diz: "Agora é que vais demonstrar se és um "lutador" 33 jovem e vigoroso, se sabes realmente lutar e executar os exercícios [de luta] no solo ${ }^{34}$.» E caindo de joelhos na cama, disse: «Vamos, lutador ${ }^{35}$, aqui tens a arena: brande a arma em riste, avança, entra a fundo! Como vês, a tua adversária está desarmada, é de aproveitar. Antes de mais, e como é lógico, cinge-a pela cintura; depois, dobra-a, chega-te bem a ela, mantém-na [apertadinha], sem deixar qualquer espaço [entre vós]. E se ela começar a ficar murcha, ergue-a sem demora, muda-a para uma posiçáo mais elevada, baixa a tua cabeça e excita-a ${ }^{36}$, mas vê lá não te retires sem to ordenarem; depois, dobra-a bem em arco e ergue-a no ar; agora, projecta-a no solo e prossegue com a... incursão Vamos! Mexe-te! Finalmente, larga-a, que a tua adversária está por terra, alquebrada e toda alagada em suor.»

Então eu, com uma sonora gargalhada, disse: "Pois agora, mestra, também eu quero mandar uns quantos exercícios; é a tua vez de obedecer: salta [da cama] e senta-te [aqui]; depois, deita-me água nas mãos, unta-me com o resto [do óleo], vai limpar-te e [finalmente], por Héracles!, aconchega-me e mete-me na cama.»

11. Nestes prazeres e jogos "atléticos", continuámos [por vários dias] a travar "combates" nocturnos, com coroaçôes ${ }^{37}$ [e tudo] - o que fazíamos com requintes de sensualidade, a ponto de me esquecer completamente da viagem a Larissa. Finalmente, um dia ocorreu-me obter a tal informação que estava na origem daquelas práticas... "desportivas". E digo-lhe: "Minha querida, deixa-me ver a tua patroa a praticar artes mágicas ou a metamorfosear-se, pois há muito tempo que anseio

${ }^{33}$ A palavra palaistês «lutador» é, como se vê da família de palaistra «luta».

34 "luta no solo»: a luta em pé constituía a primeira parte da contenda; naturalmente, a certa altura os adversários lutavam no solo (de joelhos ou deitados). O combate terminava, quando um deles obrigava o outro a assentar as espáduas.

35 «lutador»; palaitês, v. nota supra.

36 Trata-se da modalidade de sexo oral chamada cinnilingua.

${ }^{37}$ Pelos vistos, imitavam tão bem as lutas reais, que até havia, no final, a atribuição da coroa de vencedor... 
por presenciar um desses estranhos espectáculos. Ou melhor: se percebes alguma coisa do assunto, executa tu mesma uma feitiçaria capaz de te fazer aparecer com uma forma, depois com outra... Creio que náo és uma ignorante desta arte... tenho mesmo a certeza disso, não por informaçáo de terceiros, mas por experiência pessoal, porquanto, sendo eu, desde há muito, no dizer das mulheres, duro como diamante, a ponto de nunca ter lançado sobre nenhuma um olhar apaixonado, tu, por meio desta arte, tens-me cativo e encantado nesta guerra do amor.»

«Deixa-te de brincadeiras» - responde Palestra -. «Sim: que encantamento pode dominar o amor, sendo este, como é, senhor da arte mágica? Quanto a mim, caro amigo, não percebo nada dessas coisas - juro-o pela tua vida e por este bendito leito. A verdade é que nem sequer aprendi a ler... além de que a minha senhora é muito ciosa da sua arte. No entanto, se tiver oportunidade, tentarei proporcionar-te ver a minha patroa a metamorfosear-se.» Dito isto, fomos dormir.

12. Passados poucos dias, Palestra anuncia-me que a patroa iria transformar-se em pássaro e voar ao encontro do amante.

Disse então eu: «Palestra, eis a oportunidade de me fazeres o tal favor, com o que podes, enfim, saciar uma longa aspiração deste teu suplicante.»

— «Tem confiança» - respondeu.

E mal chegou a noite, pega-me pela mão, conduz-me à porta do quarto onde dormiam os amos ${ }^{38}$ e convida-me a espreitar por uma estreita fresta da porta e observar o que se passava lá dentro. Começo por ver uma mulher a despir-se; depois, toda nua, aproximou-se da candeia. com dois grãos de incenso, que lançou sobre a chama da candeia, após o que, fixando bem a luz, recitou uma longa ladainha. Seguidamente, abriu uma arca com muitas caixinhas, e de lá escolhe e retira uma; o que esta continha, não sei, mas, pelo aspecto, pareceu-me óleo. Tira um pouco deste [produto], besunta-se toda, principiando pelas unhas dos pés... e eis que, de súbito, lhe começa a despontar um par de asas; depois, o nariz tornou-se córneo e adunco... enfim, tinha todos os pertences e atributos das aves; mais

${ }^{38}$ Não é crível que o marido e a mulher dormissem no mesmo quarto, pois isso impediria a acção da mulher feiticeira. Entenda-se, entáo, que o Autor-narrador se refere à zona da casa destinada a dormitório, com pelo menos dois quartos. 
precisamente, era, sem tirar nem pôr, uma coruja ${ }^{39}$. Mal se viu provida de asas, lançou um terrível grasnado, como essas tais corujas, e, elevando-se no ar, saiu pela janela voando.

13. Então eu, cuidando estar a sonhar, esfregava as pálpebras com os dedos, sem acreditar nos meus próprios olhos: nem que estivessem a ver, nem que estivessem acordados. Quando, porém, me convenci (aliás a muito custo e lentamente) de que não estava a dormir, roguei a Palestra que me desse asas, besuntando-me com aquela droga, e que me proporcionasse levantar voo. $\mathrm{Na}$ verdade, pretendia saber, por experiência própria, se, ao deixar de ser homem, também ficaria pássaro quanto ao pensamento. Então ela abriu devagarinho a porta do quarto e trouxe a caixinha. E eu, num ápice, dispo-me e besunto-me todo... Todavia, desgraçado de mim!, náo me transformo num pássaro, mas, pelo contrário, nasceu-me uma cauda no traseiro, e, quanto aos dedos [de mãos e pés], foram sei lá para onde: apenas fiquei, ao todo, com quatro unhas, que mais não eram que cascos; também as mãos e os pés se transformaram em patas de besta; as orelhas ficaram enormes, o rosto comprido. Enfim, observando-me todo à volta, via-me um burro... e é que nem ao menos tinha voz de homem para censurar Palestra. Então, alongando a beiça de baixo, olho-a de esguelha e, pela minha própria figura de burro, comecei a acusá-la, conforme podia, por me ter transformado em burro, em vez de pássaro.

14. Então ela, arranhando o rosto com ambas as mãos, exclamou: «Desgraçada de mim! Acabo de fazer um grande mal: na minha precipitaçáo, deixei-me enganar pela semelhança das caixinhas e peguei numa outra, diferente da que fazia nascer asas. Mas anima-te, querido, que o caso é fácil de remediar: basta comeres rosas, que imediatamente te despirás da besta e voltarás a ser outra vez o meu amante. Portanto, meu querido, aguenta apenas esta noite sob a forma de burro, que, logo de manházinha, irei a correr buscar-te rosas para tu comeres e te curares.» E, ao mesmo tempo que dizia estas palavras, afagava-me as orelhas e o resto do corpo.

39 Trata-se, sem dúvida, duma ave nocturna, que o texto designa por "corvo nocturno" (kórax nykterinós), e que deve ser a mesma a que Aristóteles chama nuktikórax. 
15. Ora eu, que, em tudo o mais, era um burro, continuava, no entanto, e no tocante a sentimentos e inteligência, a ser aquele mesmo homem, Lúcio... excepto na fala. Por conseguinte, foi em pensamento que praguejei contra Palestra, pelo seu erro; depois, mordi os beiços e dirigi-me para onde sabia que estava o meu cavalo e um outro burro, autêntico, pertencente a Hiparco, os quais, porém, ao sentirem-me entrar, e receosos de que eu viesse como mais um "sócio" do feno, baixaram as orelhas, prontos a defender a barriga com as patas. Então eu, ao perceber a coisa, retirei-me para um lugar um tanto afastado da manjedoura e ali fiquei, a rir... mas o meu riso não era mais que um ronco. E cogitava comigo mesmo: "Mas que curiosidade ${ }^{40}$ a minha, táo inconveniente! E se entrasse aqui um lobo ou qualquer [outro] animal feroz? Sem ter a mínima culpa, estou a correr um risco.» Isto era o que eu pensava, desconhecendo (infeliz de mim!) o mal que estava para vir.

16. De facto, já ia alta a noite, o silêncio era total e o sono doce... eis senão quando, ouve-se um barulho na parede, do lado de fora, como se estivessem a perfurá-la ${ }^{41}$ - e é que estavam mesmo. E até já tinham feito um buraco capaz de deixar passar uma pessoa; e logo por ele passou um homem, a seguir outro... até se encontrarem muitos lá dentro, todos armados de espadas. Em seguida, penetraram nos quartos de Hiparco, de Palestra e do meu criado, amarraram-nos e começaram, com toda a impunidade, a esvaziar a casa, levando para fora dinheiro, vestuário e móveis. E quando já nada restava dentro de casa, apoderaram-se [de $\mathrm{mim}^{42}$ ], do outro burro e do cavalo, selaram-nos, e depois puseram-nos nos lombos tudo quanto haviam arrebanhado. Assim carregados com tão grandes fardos, ainda por cima nos zurziam com paus e nos levavam em direcção à montanha, tentando fugir por um caminho não batido. Quanto aos outros [dois] animais, não posso dizer o que sentiam, mas eu, que não estava habituado a andar descalço, fiquei para morrer,

${ }^{40}$ A palavra periergía, além do sentido comum de "curiosidade», também significava «magia», «bruxaria». Talvez fosse de traduzir por algo como «curiosidade mágica». O sentido é: «Mas quem me mandou a mim meter-me em bruxarias?».

${ }^{41}$ Para os ladróes da antiguidade, era mais fácil furar a parede de uma casa, que arrombar a porta. Daí que um dos nomes para os designar seja, precisamente, toikhorýkhoi, "furadores de paredes».

$42 \mathrm{O}$ texto diz "apoderaram-se também do outro burro e do cavalo». É evidente (e o texto permite-o) que o burro-Lúcio também foi levado. 
caminhando sobre pedras aguçadas e com uma carga tão pesada em cima de mim. Tropeçava muitas vezes, mas não me era permitido cair, pois logo algum deles, por detrás, me zurzia as coxas com um varapau. E todas as vezes que tentava exclamar "Ó César!», mais não conseguia que um ronco, apenas me saindo um «Óóóó» prolongado e sonoro... mas o "César» é que não havia meio de acompanhar... E até por via disso apanhava porrada, por estar a denunciá-los com a roncaria. Por isso, convencido de estar zurrando para nada, decidi caminhar em silêncio, pois [ao menos] ganhava em não ser zurzido.

17. Neste entretanto, amanheceu. Já tínhamos subido muitos montes, mas levávamos os focinhos açaimados, de forma que não perdêssemos tempo no caminho a pastar a nossa ceia. Assim, ainda por todo esse dia, continuei burro. Ora, precisamente ao meio-dia, fizemos escala numa quinta pertencente a umas pessoas íntimas dos ladróes - tanto quanto se podia deduzir pelos factos: realmente, cumprimentaram-se mutuamente com beijos, e os da quinta convidaram-nos a pernoitar ali, serviram-lhes o almoço, e a nós, as bestas, puseram-nos cevada. Os meus companheiros, esses sim, comiam... eu é que passei uma fome desgraçada: como ainda nunca tinha comido cevada ao natural, pus-me a matutar no que havia de comer. É então que topo uma horta ali mesmo por detrás do pátio, na qual havia hortaliça, muita e da boa, e por entre a hortaliça sobressaíam umas rosas. Então eu, fazendo-me passar despercebido a todos os que, lá dentro, se ocupavam do almoço, dirijo-me à horta, em parte para me atafulhar de verduras cruas, mas em parte, também, por causa das rosas, pois cuidava que, comendo daquelas flores, voltaria de novo a ser homem. Entrei pela horta dentro e atafulhei-me de alfaces, de rábanos e de aipos, tudo coisas que o homem come ao natural; quanto às rosas, porém, não eram rosas autênticas, mas daquelas que nascem do loureiro selvagem ${ }^{43}$; as pessoas é que lhes chamam "rosas de loureiro", aliás um funesto alimento para tudo o que é burro ou cavalo: segundo se diz, quem as comer morre imediatamente.

${ }^{43}$ Pode tratar-se do loureiro-rosa, também chamado loendro ou aloendro, cevadilha, rododendro. Com tantas centenas de espécies, os gregos, naturalmente (como qualquer de nós...), davam o mesmo nome a espécies diferentes, que só os botânicos distinguem. 
18. Nisto, o hortelão dá pela minha presença. Pega num fueiro, entra na horta e, ao ver o inimigo e a razia nas hortaliças, qual tirano severo quando apanha um ladrão, deu-me uma coça de varapau, náo me poupando nem o lombo nem as coxas, e até mesmo me zurziu as orelhas e me "esfregou" o focinho. Então eu, já sem poder mais, apliquei-lhe uma parelha de coices, pregando com ele de pantanas em cima das hortaliças, e fugi monte acima. Ao ver que eu me punha ao fresco, o tipo começou a bradar que soltassem os cães no meu encalço - cães que eram, de facto, em grande número e enormes, capazes até de lutar com ursos. Percebi que, se me apanhassem, me estraçalhavam todo, pelo que, após breve corrida de diversão, optei por aquele conselho da fábula ${ }^{44}$ : «Mais vale recuar, que correr para a morte». Voltei, pois, para trás e entrei novamente no estábulo. Então eles chamaram os cães, que já vinham na minha peugada, e prenderam-nos; mas a mim fartaram-se de me dar porrada, e não me deixaram senáo quando, por via das dores, vomitei toda a hortaliça... por baixo.

19. Chegada a hora de se porem a caminho, atiraram-me para o lombo os mais pesados e a maioria dos artigos roubados, e assim nos partimos dali. Vendo-me sucumbir à pancadaria e ao peso da carga, e, para mais, com os cascos arrasados da caminhada, tive a ideia de me deitar ali mesmo e não me levantar mais, ainda que me matassem à porrada. Contava eu obter uma grande vantagem com esta minha resolução; sim, cuidava que eles acabariam por se dar por convencidos e distribuiriam a minha carga pelo cavalo e pelo [outro ${ }^{45}$ ] burro, e que a mim me deixariam ficar para ali, entregue aos lobos... Só que... houve algum espírito maligno que, adivinhando os meus propósitos, os virou de pantanas. De facto, o outro burro, talvez pensando o mesmo que eu, deixa-se cair no meio do caminho. Então os homens, a princípio, batiam-lhe com um pau e intimavam-no a levantar-se; como ele, porém, não ligava às pancadas, pegaram nele, uns pelas orelhas, outros pelo rabo, tentando fazê-lo erguer-se. Vendo que nada conseguiam,

44 Tanto pode tratar-se duma fábula (cuja "moralidade» passara a provérbio), como dum provérbio independente. De qualquer forma, o Autor-narrador cita um pensamento certamente bem conhecido.

${ }^{45}$ A palavra outro náo está no texto... e com toda a razão, do ponto de vista do narrador. Este, no entanto, um pouco mais abaixo, diz explicitamente "o outro burro». 
e como o animal continuasse deitado no meio do chão, como uma pedra e completamente esgotado, concluíram, lá entre eles, que estavam a esforçar-se em vâo e a gastar o [seu precioso] tempo de fuga às voltas com um burro morto. Assim, distribuíram por mim e pelo cavalo toda a bagagem que aquele transportava; depois, foram-se ao nosso infeliz camarada de cativeiro e de frete, raparam da espada, cortaram-lhe as pernas rente e lançaram-no, ainda palpitante, num precipício. Lá ia ele, por ali abaixo, dançando a dança da morte...

20. Então eu, vendo no exemplo do meu companheiro de viagem o [que seria] o fim dos meus dias, resolvi aguentar com galhardia a situaçáo presente e caminhar zelosamente, sempre, porém, na expectativa de, mais tarde ou mais cedo, encontrar as rosas e, por via delas, recuperar a minha forma própria. Para mais, ouvi os ladróes dizerem que já não faltava muito que caminhar e que ficariam instalados nesse ponto da sua chegada. Assim, e com passada larga, lá íamos carregando com aquela tralha toda, e antes do anoitecer chegámos aos nossos domínios. Lá dentro, estava sentada uma velha, e também ardia uma grande fogueira. Os homens meteram em casa tudo o que nós havíamos transportado, e depois perguntaram à velha: "Que estás para aí sentada, em vez de nos preparares a ceia?»

— «Mas está tudo pronto» - respondeu a velha -: "pão com fartura, pipos de vinho velho, e até tenho, já cozinhada, carne de caça brava.»

Elogiaram a velha, despiram-se, untaram-se com óleo junto do lume e serviram-se dum caldeirão com água quente, que deitavam uns aos outros, arranjando assim um banho improvisado.

21. Um pouco mais tarde, chegou um numeroso bando de jovens, que transportavam uma enorme quantidade de objectos de oiro e de prata, vestuário e muitas jóias de mulher e de homem. Estes últimos tinham sociedade com os $\operatorname{outros}^{46}$. Logo que puseram as coisas dentro de casa, foram também lavar-se, e a seguir houve uma ceia magnífica e uma

46 "tinham sociedade com os outros», i. é, com os primeiros. Há quem traduza por «eram sócios entre si», o que é manifestamente inexacto, como se vê pelo que se segue e, ainda, pela história que, mais desenvolvidamente, nos conta Apuleio (O Burro de Oiro). 
longa sessão de conversa durante $o$ [subsequente $\left.{ }^{47}\right]$ beberete dos bandidos. Entretanto, a velha deitara cevada para mim e para o cavalo. Este devorava a cevada a toda a pressa, naturalmente com receio de mim, seu comensal. Eu, porém, mal via a velha ir lá fora, comia um pão dos que estavam na sala.

No dia seguinte, deixaram um único jovem com a velha e partiram todos os outros para o "trabalho". Eu é que lamentava a minha sorte mais o rigor da vigilância: em boa verdade, era-me fácil iludir a velha, tinha possibilidades de fugir do seu raio de visão... mas o moço era grandalhão, tinha ar de poucos amigos $^{48}$ e, além disso, trazia sempre consigo a espada e estava permanentemente colado à porta.

22. Três dias depois, perto da meia-noite, regressaram os ladrôes, sem trazerem nem ouro nem prata nem o que quer que fosse, excepto uma donzela na flor da idade e muito formosa, que chorava, rasgava o vestido e arrepelava ${ }^{49}$ os cabelos. Levaram-na para dentro, deitaram-na num leito de folhas e incitaram-na a ter coragem; e à velha ordenaram-lhe que ficasse sempre em casa e a mantivesse debaixo de olho. Ora a rapariga recusava-se a comer e a beber fosse o que fosse e náo parava de chorar e arrepelar os cabelos, a ponto de eu próprio, que estava ao pé da manjedoira, desatar também a chorar por essa formosa donzela. Neste entretanto, os ladróes ceavam lá fora, no pátio. Pela madrugada, um dos sentinelas, a quem coubera a missão de vigiar os caminhos, vem anunciar que um estrangeiro ia passar por ali, e que devia transportar uma grande riqueza. Entáo eles, tal como estavam, levantaram-se, pegaram nas armas, selaram-me a mim e ao cavalo e puseram-se a caminho. Mas eu, desgraçado!, consciente de que partia para a batalha, para a guerra, marchava de má vontade, pelo que apanhava cacetadas, pois eles tinham muita pressa. Quando chegámos à estrada

${ }^{47}$ A palavra subsequente não está no original, mas a ideia não podia deixar de estar implícita: a seguir à ceia propriamente dita, seguia-se um período de sympósion, ou beberete, que era especialmente dedicado à discussão dos mais variados assuntos.

${ }^{48}$ Literalmente: "olhava de maneira aterradora» ou "tinha um olhar medonho".

49 "rasgava o vestido e arrepelava os cabelos»: o texto grego usa um só verbo, comum às duas acçóes. Em português, o desdobramento parece uma solução inevitável. Um pouco mais adiante, o mesmo verbo (na sua forma simples, náo composto) tem como complemento apenas «cabelos». 
por onde o estrangeiro ia $\left[\mathrm{a}^{50}\right]$ passar, os ladróes caíram sobre os carros e mataram-no, bem como aos criados; em seguida, retiraram todos os objectos de maior valor e colocaram-nos no lombo do cavalo e no meu; quanto ao resto dos artigos, esconderam-nos ali mesmo no bosque. Depois conduziram-nos de regresso; mas eis que eu, forçado a mexer-me e zurzido com o cacete, dou uma topada com o casco numa pedra aguçada, tendo resultado da pancada uma ferida muito dolorosa; e foi a coxear que fiz o resto da caminhada. Entáo eles começaram a dizer uns para os outros: "Que ideia a nossa de alimentar este burro, que está sempre a cair! Lancemo-lo mas é do precipício abaixo, este presságio de mau agoiro ${ }^{51}$.»

«Sim»- dizem eles -, "lancemo-lo, para servir de vítima expiatória do nosso exército ${ }^{52}$.»

E já estavam para se atirar a mim, mas eu, ao ouvir as suas palavras, fui marchando, daí em diante, como se a minha ferida fosse... de outro: o pavor da morte tornara-me insensível à dor.

23. Chegados ao sítio onde nos acoitávamos, tiraram-nos a bagagem de cima do lombo, arrumaram-na muito bem, sentaram-se e começaram a jantar. Ao cair da noite, saíram a recuperar o resto dos artigos. E diz um deles: «Para quê levar este burro miserável, inutilizado dum casco? Nós mesmos carregaremos com parte do material, e o cavalo com a outra parte.» E lá foram, levando [só] o cavalo. Estava uma esplêndida noite de luar. Então disse para comigo mesmo: "Ó mísero! Porque insistes em ficar aqui? Os abutres e os filhotes dos abutres comer-te-ão à ceia. Não ouviste o que tramaram contra ti? Queres rebolar pelo precipício abaixo? Ora bem: é de noite, está lua cheia, os tipos foram-se, estão fora... Póe-te em fuga e livra-te de patróes assassinos.»

Estava eu nestas cogitaçôes comigo mesmo, quando reparo que não estava amarrado a nada: a arreata, que me arrastava nas minhas deslocaçóes, estava pendurada - facto que ainda mais me espicaçou a pôr-me em fuga... e de facto ia mesmo

${ }^{50}$ Rigorosamente: "por onde o estrangeiro devia passar», ou «... ia passar». A ideia justifica-se em relaçáo a um tempo anterior, em que se previa a sua passagem naquele sítio. Neste momento, porém, o estrangeiro, como se vê pelo próprio texto, já ia a passar.

${ }^{51}$ Literalmente: "esta ave (ou, metaforicamente, presságio) nada boa».

52 Referência aos sacrifícios de purificação (cf. «bode expiatório»»), próprios dos exércitos, mas também aqui aplicado às quadrilhas de ladróes... 
partir a todo o galope. A velha, porém, vendo-me já pronto a evadir-me, agarra-se-me à cauda, e é que não havia meio de me largar. Então eu, achando que ser vencido por uma velha era coisa merecedora do precipício e de todo o género de mortes, arrastei-a comigo; e a velha pôs-se a bradar em altos berros, lá para dentro, para a rapariga cativa, a qual, assomando à porta e vendo uma velha... Dirce ${ }^{53}$, mas atracada a um... burro, tem um nobre gesto de heroísmo, digno de um jovem desesperado: salta-me em cima e parte escarranchada no meu lombo. E eu, já pelo desejo de fugir, já com o incitamento da rapariga, lancei-me em fuga a trote de cavalo, deixando a velha para trás. A donzela suplicava aos deuses que a salvassem naquela sua fuga; e a mim dizia-me: «Ó meu lindo, se me conduzires a casa de meu pai, isentar-te-ei de todo e qualquer trabalho e terás ao almoço, e por dia, um medimno ${ }^{54}$ de cevada.» $\mathrm{E}$ eu, não só para escapar aos meus assassinos, mas também na mira de lograr socorro e bom tratamento da parte da rapariga que eu salvara, não parava de correr, sem ligar à minha ferida.

24. Chegados, porém, a um sítio onde a estrada se dividia em três ${ }^{55}$, os nossos inimigos, já de regresso, surpreenderam-nos, e imediatamente reconhecem, de longe, mas com o luar de chapa, os seus infelizes prisioneiros. Correm para nós, lançam-me a mão e dizem: "Ó virtuosa menina, aonde vais tão fora de horas, pobrezinha? Não tens medo de fantasmas? ${ }^{26}$ Ora chega-te aqui a nós, que vamos entregar-te à tua família.» E diziam isto com um riso sardónico; depois, fizeram-me dar meia volta e levaram-me pela arreata. Então lembrei-me novamente da minha pata e do ferimento, e come-

53 "vendo uma velha... Dirce, mas atracada a um... burro»: com as reticências e o mas (que náo consta do original), tentei, dalgum modo, traduzir o factor de surpresa linguística, que o leitor antigo imediatamente sentiria, pois a mitologia diz que Dirce foi amarrada aos cornos dum touro furioso, que a despedaçou...

${ }^{54} \mathrm{O}$ medimno equivalia a c. 50 litros... mas nisto de medidas antigas não há que fiar. Em todo o caso, a aflição da rapariga está de acordo com a grandeza da promessa.

55 Trata-se de uma encruzilhada, que os antigos viam de duas maneiras: a) como um ponto de confluência de três vias, gr. triodos, lat. triuium "trívio" = "três vias»; b) como um caminho que, a certa altura, se dividia em três: em frente, à esquerda e à direita, ou seja, uma encruzilhada.

${ }^{56}$ A palavra daimónion, que na literatura cristã passou a significar «espírito maligno» e "demónio», tem aqui, igualmente, sentido pejorativo. Quanto à crença em fantasmas, o menos que podemos dizer é que, no tempo de Luciano, estava na moda. 
cei a coxear. Dizem eles: "Com que então... agora, que foste apanhado a escapulir-te, já és coxo, heim? Mas quando se tratava de fugir, estavas são, mais veloz que um cavalo, capaz até de voar...»E a estas palavras vinha juntar-se o varapau, de modo que, assim reprimido, já tinha uma chaga na coxa. Ao chegarmos de novo a casa, deparámos com a velha enforcada com uma corda e pendurada num rochedo. Efectivamente, temendo, pelos vistos, os seus amos, por causa da fuga da rapariga, pôs uma corda ao pescoço e lançou-se. Os homens gabaram o bom senso da velha; depois, cortaram [a corda] e deixaram-na cair no fundo do precipício, tal como estava, isto é, com o nó ao pescoço; quanto à jovem, amarraram-na numa sala; depois foram cear, e a seguir houve um longo beberete.

25. A certa altura, começaram a falar uns com os outros a respeito da rapariga: "Que fazemos da fugitiva?» - disse um deles. "Ora» - respondeu outro -, "que há-de ser, senão mandá-la dali abaixo, a fazer companhia à velha? Além de ter feito o possível por nos privar de bom dinheiro ${ }^{57}$, ainda ia denunciar a nossa "associação" 58 ; sim, meus amigos, fiquem sabendo que, se a fulana voltasse ao seio da família, nem um sequer de nós ficaria vivo: os nossos inimigos cairiam sobre nós, em ataque organizado, e seríamos apanhados. Portanto, vinguemo-nos da nossa inimiga... mas que não morra com essa simplicidade toda, despenhando-se de encontro às rochas; inventemos-lhe antes a morte mais dolorosa e mais lenta possível, uma coisa que a mantenha longamente sob tortura, e que, por fim, a mate.»

Puseram-se então a discutir o género de morte. Diz um: «Estou certo de que vocês vão aprovar o plano que arquitectei. Ora bem: [em primeiro lugar] há que matar o burro, que é um preguiçoso, agora a fingir de coxo, e que, de mais a mais, se prestou a ser criado e colaborador na fuga da rapariga. Portanto, logo de manhã, degolamo-lo ${ }^{59}$, abrimos-lhe a barriga e tiramos-lhe todas as vísceras; depois, introduzimos esta formosa donzela dentro do burro, mas com a cabeça de

57 Entenda-se: proveniente de futuro resgate.

58 A palavra ergastêrion significa, propriamente, "oficina», mas pôde ganhar também o sentido de "associaçáo de oficiais do mesmo ofício".

59 «degolamo-lo, abrimos... tiramos...» etc.: no original, os verbos estão no conjuntivo-imperativo ("degolemo-lo...» etc.), que, neste contexto, me pareceu um tanto artificial do ponto de vista linguístico em português. 
fora do animal, para que não sufoque logo, mas com o resto do corpo encerrado lá dentro; com ela nessa posição, cosemos muito bem [a pele do burro] e lançamos ambos aos abutres - o que constituirá um almoço como nunca se viu. Reparem, meus amigos, no requinte desta tortura; primeiro, coabitar com um burro; depois, no pino do verão e sob um sol ardentíssimo, ir assando dentro do animal, ir morrendo com uma fome que mata lentamente, e sem ao menos poder dar a morte a si própria - para já náo falar do mais que sofrerá, à medida que o burro vai apodrecendo e ela se vê misturada com o pivete e com os vermes. Por fim, os abutres penetrarão através do burro e, tal como fazem a este, despedaçá-la-ão, talvez ainda com vida.»

26. Todos aplaudiram esta invenção monstruosa, como se de grande façanha se tratasse. Eu é que me carpia, à ideia de ir ser degolado, e sem que ao menos o meu cadáver repousasse em paz. Pelo contrário, iria recolher uma infeliz donzela, ser o túmulo duma menina inocente.

Já de madrugada, porém, eis que, subitamente, surge uma companhia de soldados, enviada contra os bandidos; imediatamente os prenderam a todos e os conduziram ao governador do distrito. Ora, sucedeu que o noivo da rapariga também viera com os soldados, pois foi ele quem denunciou o covil dos ladróes. Por isso, tomou conta da jovem, montou-a em cima de mim e, dessa forma, conduziu-a a caminho de casa. Os aldeóes, ao avistarem-nos ainda de longe, já sabiam que vínhamos felizes, pois eu encarreguei-me de lhes... zurrar antecipadamente a boa nova. Acorreram a saudar-nos e acompanharam-nos até a casa.

27. A rapariga mostrava grande consideração por mim, fazendo justiça ao cativo que com ela se evadira e que com ela correra o mesmo e tão grande perigo de morte. Então, da parte da patroa, puseram-me na frente, para o almoço, um medimno ${ }^{60}$ de cevada e uma porção de feno que dava para um camelo. Eu, mais do que nunca, rogava pragas a Palestra, cujas malas-artes me haviam transformado em burro, e não em cáo. De facto, via os cães entrar na cozinha e alambazar-se de tudo o que costuma haver em bodas de gente rica.

Alguns dias, náo muitos, depois do casamento, como a minha dona, diante do pai, exprimisse a sua gratidão por mim, o

${ }^{60}$ c. 50 litros, mas v. nota supra. 
pai, querendo recompensar-me com justa paga, ordenou que me deixassem em liberdade, no campo, a pastar com as éguas da manada. "Pois, pois» - disse ele -, «em liberdade viverá feliz e cobrirá as éguas.» Uma tal recompensa parecia, na circunstância, a mais justa... se o caso se passasse com um... burro-juiz. Chamou, pois, um dos tratadores de cavalos e entregou-me a ele; e eu, cá por mim, estava contente por nunca mais ter de alombar com cargas. Chegados ao campo, o pastor juntou-me com as éguas e conduziu-nos em manada para a pastagem.

28. Mas, justamente neste momento, tinha de me acontecer o mesmo que a Candaules ${ }^{61}$. De facto, o maioral dos cavalos pregou comigo em casa, ao serviço de sua mulher Megálope, a qual passou a atrelar-me ao moinho, para lhe moer trigo e toda a espécie de cevada ${ }^{62}$ - o que, ainda assim, constituía um mal menor para um burro bem agradecido: moer para os seus próprios tratadores. A "boa senhora"63, porém, alugava o meu pescoço a troco de farinha que [por esse trabalho] exigia às pessoas daqueles campos, que eram muitíssimas. E quanto à cevada destinada ao meu almoço, torrava-a e depois obrigava-me a moê-la, para fazer bolinhos, que devorava; e a mim deixava-me os farelos como almoço. E se alguma vez por acaso o pastor me levava para junto das éguas, era barbaramente sovado e mordido pelos garanhóes; Efectivamente, estes, sempre desconfiados de que eu cometia adultério com as éguas suas esposas, escorraçavam-me com parelhas de coices, de modo que não podia suportar este ciúme... hípico. Assim, desgostoso com o [trabalho do] moinho e, por outro lado, sem poder pastar no campo, onde era hostilizado pelos meus companheiros de pastagem, não tardei a ficar magro e feio.

29. Além disso, mandavam-me com muita frequência lá acima, ao monte, para transportar lenha no lombo, o que era o cúmulo dos meus males: em primeiro lugar, tinha de escalar uma alta montanha, por um caminho terrivelmente escarpado; depois, o monte era pedregoso e eu ia desferrado, e ainda por cima mandavam

${ }^{61}$ A história de Candaules, contada por Heródoto (I, 8-12), é dum picante muito divertido, mas longa para esta nota. Fique somente a moralidade: tão bem que nós estávamos...

${ }^{62}$ Literalmente: «... e toda a cevada». Julgo que inclui cevada, aveia e diversos tipos similares.

63 «boa senhora”, naturalmente, em sentido irónico. 
comigo, como meu condutor, um rapazola infame, que de cada vez tentava um novo meio de acabar comigo: primeiro, ainda que eu corresse a valer, zurzia-me, náo com um simples pau, mas com um que tinha nós muito juntos e salientes, e, para mais, batia-me sempre no mesmo ponto da coxa, de forma que, de tanta paulada, a coxa, naquele sítio, ficou em carne viva... e o fulano vá de arrear sempre na chaga. Depois, punha-me no lombo uma carga tal, que mesmo para um elefante era penosa de suportar. A própria descida do monte era dolorosa, e também aí me batia; e se via a carga a descair e a inclinar-se para um dos lados, em vez de retirar parte da lenha e passá-la para o lado mais leve, a fim de restabelecer o equilíbrio, não fazia nada disso, mas antes apanhava no monte umas pedras enormes e punha-as de contrapeso na parte mais leve da carga, aquela que tendia para cima. E o mofino de mim lá seguia por ali abaixo, alombando, simultaneamente, com a lenha e com pedras inúteis. Havia também, no nosso trajecto, uma ribeira de corrente perene; então o fulano, para poupar os sapatos, atravessava a ribeira montado em cima de mim, por detrás da lenha.

30. E se algumas vezes, de tão derreado com a carga, eu me ia abaixo, então é que a coisa se tornava insuportável: quando o que se impunha era estender-me a mão ${ }^{64}$ para me ajudar a erguer-me do chão ou aliviar-me da carga, não senhor, nunca por nunca me deu uma mão, mas, pelo contrário, mesmo de cima de mim, zurzia-me com pauladas na cabeça e nas orelhas, até que as bordoadas me fizessem levantar. Além disso, costumava pregar-me uma outra partida igualmente insuportável: colhia uma porção de espinhos muito aguçados, atava-os num molho e pendurava-os na parte de trás, pela cauda; é claro que, com o andamento, os espinhos baloiçavam, vinham de encontro a mim, arranhavam-me o traseiro e feriam-me; e é que era mesmo impossível defender-me, uma vez que os aguilhóes, pendurados em mim, continuavam a perseguir-me. Quer dizer: se. para me livrar do ataque dos espinhos, caminhava suavemente, era barbaramente sovado à paulada; e se, por outro lado, tentava evitar o cacete, lá me caía no traseiro aquele flagelo picante. Em resumo: o meu condutor fazia questão de acabar comigo.

${ }^{64}$ Neste passo, a lição dos manuscritos é muito difícil, pelo que cada editor moderno propóe a sua emenda. Também se poderia corrigir (com outra lição): «não estava para se apear, a fim de me estender a mão...» 
31. Até que um belo dia, já sem suportar mais os inúmeros maus tratos por que passava, apliquei-lhe um coice - e coice foi esse, que o fulano o conservou longamente na memória. Ora, uma vez, recebe ordem para transportar estopa duma terra para outra. Então, foi buscar-me e reuniu uma enorme quantidade de estopa, que atou ${ }^{65}$ ao meu lombo, mas (já a maquinar ${ }^{66}$ tramar-me à grande) fixou-me bem a carga com uma corda bastante incomodativa. Já prestes a partir, surripiou da lareira um tição ainda a arder e, quando já nos encontrávamos longe da quinta, introduziu o tiçáo dentro da estopa. Esta, como não podia deixar de ser, começou logo a arder, e daí a nada a minha carga náo passava duma fogueira gigantesca. Então eu, apercebendo-me de que náo tardaria a ficar estorricado, e topando um charco fundo que havia no caminho, lanço-me no local mais aguado do charco, onde iam revolvendo a estopa, dando voltas e espojando-me na lama, até que consegui apagar aquela carga ardente e angustiante. Deste modo, fiz o resto da caminhada já sem perigo de maior. Realmente, o rapaz já não conseguia pegar-me fogo, pois a estopa estava encharcada em lama muito rala ${ }^{67}$. Mesmo assim, o desavergonhado teve alma de me incriminar, dizendo que fui eu que, por minha iniciativa, me espojei na lareira ao passar por lá. Mas, pelo menos dessa vez, e sem o esperar, escapei da estopa.

32. [Uma outra vez] o infame do rapaz inventou contra mim uma maldade muitíssimo superior. De facto, levou-me para o monte e aí pôs-me sobre o lombo uma enorme carga de lenha, que foi vender a um lavrador que morava nas imediaçóes. Depois trouxe-me para casa, em pêlo e sem a lenha, e [ainda por cima] me acusou a mim, perante o patrão, duma façanha ímpia: «Meu amo, não entendo por que razão alimentamos este burro, espantosamente preguiçoso e lazarento. Agora apanhou um novo hábito: mal vê uma mulher jovem, bela e viçosa, ou um moço, atira-me um coice e parte a galope no seu encalce; e é que faz amor como um autêntico homem: bandeando-se sobre a mulher amada, morde-a em jeito de beijá-la e

${ }^{65}$ Em vez de katédêse "atou", "amarrou", dava mais jeito a forma katéthêse "pôs», "colocou», i. é, "pregou-me» (com ela no lombo). O acto de "atar», "amarrar», "fixar», é referido a seguir.

${ }^{66} \mathrm{O}$ texto grego, tyreuo, "amassar queijo", ganha aqui o sentido metafórico de "tramar», "maquinar», sem dúvida usual, popular e muito expressivo.

${ }^{67}$ Literalmente: «(muito) aguada». 
obriga-a a ter relaçóes. Por via disto, ainda te há-de arranjar processos e mais chatices, tantas são já as pessoas molestadas e mandadas abaixo. Ainda agora (ia ele com uma carga de lenha), ao ver uma mulher que se dirigia a um campo, sacudiu a carga, que se espalhou toda pelo chão, e, vai daí, estende a mulher ao comprido, na estrada, e pretendia acasalar com ela... até que, de diversos lados, acorreu gente em defesa da mulher e a evitar que ela fosse despedaçada por este lindo amante.»

33. Informado deste facto, disse o patrão: «Pois então, se ele não quer andar nem fazer fretes, e se, além disso, tem acessos de paixão à maneira dos humanos e tenta "espetar"68 mulheres e rapazes, degolem-no, dêem as vísceras aos cães, e guardem a carne para os trabalhadores. E se [o patrão] perguntar como é que ele morreu, atirem as culpas para cima do lobo.»

Ora, o infame do meu condutor estava encantado e queria degolar-me imediatamente. Aconteceu, porém, estar presente, nesse momento, um dos lavradores nossos vizinhos, e foi este que, ao propor contra mim um plano horrível, me livrou da morte.

— «Nada disso» - disse ele -, «náo degolem um burro ainda capaz de trabalhar no moinho e no transporte de carga. A coisa é simples: já que ele se atira às pessoas com paixão erótica e de "espada" em riste ${ }^{69}$, vão-se-lhe à "arma»" e cortem-lha. Sim, uma vez privado desse ardor, logo ficará manso e até mais gordo, e então já suportará uma grande carga sem o mínimo protesto. E se tu não tens experiência desta operação, dentro de três ou quatro dias virei eu aqui, capo-o e ponho-to mais bem comportado que um cordeiro.»

Toda a gente lá em casa gabou este conselheiro: que [sim senhor], dizia muito bem. Eu é que já não fazia senão chorar, na perspectiva de ir em breve perder, no burro, a minha virilidade; e confessava que desistiria de viver, se me tornasse eunuco. Assim, a partir desse momento, decidi abster-me completamente de alimento, ou então atirar-me do alto da montanha: precipitando-me dali abaixo, morreria duma morte bem digna de dó, mas, pelo menos, com o cadáver inteiro e intacto.

${ }^{68} \mathrm{O}$ verbo oistrô significa, em sentido próprio, «espetar», «espicaçar» (com um objecto pontiagudo); o contexto (mais as aspas...) dão o sentido erótico.

${ }^{69} \mathrm{O}$ texto diz "com o aguilhão», em sentido figurado, é claro.

70 "à arma», ou seja, "ao aguilhão»; aliás, o texto emprega somente o pronome: «a ela» (arma) ou «a ele» (o aguilhão). 
34. Já era alta noite, porém, eis que um mensageiro, vindo do povoado, chegou ao campo e à nossa quinta, anunciando que aquela rapariga, a recém-casada, a tal que estivera em poder dos ladrôes, assim como o seu marido... andando os dois a passear na praia, ao cair da noite... de repente, veio uma onda da maré cheia, que os arrebatou a ambos e os engoliu, tendo assim encontrado uma morte trágica. Então, uma vez que a casa se encontrava privada dos jovens amos, decidiram abandonar a sua condição de escravos ${ }^{71}$, pelo que pilharam todo o recheio e se puseram em fuga. O maioral dos cavalos pôs-me de parte, arrebanhou tudo o que pôde e carregou-me a mim, às éguas e às restantes bestas. Pela minha parte, embora irritado por levar uma carga própria dum autêntico burro, mesmo assim aceitei gostosamente este embargo à minha castração. Caminhando toda a noite por um caminho penoso, e após mais três dias de viagem apressada, chegámos a Bereia, importante e populosa cidade da Macedónia.

35. Os nossos condutores resolveram instalar-se nessa terra, pelo que puseram à venda as bestas, ou seja, nós. Um pregoeiro de falas lisonjeiras pôs-se no meio da praça a apregoar. E as pessoas aproximavam-se, abriam-nos a boca para inspeccionar, para ver, pela dentuça, a idade de cada um de nós; um adquiriu um animal, outro adquiriu outro... só eu fiquei até ao fim, pelo que o pregoeiro aconselhou [o dono] a levar-me de novo para casa: «Estás a ver»- disse ele -, «este foi o único que não encontrou comprador.» Todavia, Némesis, a deusa que, tantas vezes, faz girar e mudar a sorte, trouxe-me um amo do género que eu nunca desejaria. Tratava-se dum velho pederasta, um daqueles tipos que andam pelos campos, de povoado em povoado, transportando a Deusa Síria ${ }^{72}$ e forçando a divindade à condição de pedinte. Sou vendido a este fulano pelo preço astronómico $^{73}$ de trinta dracmas. E lá fui eu, gemendo, atrás do meu [novo] amo.

${ }^{71}$ Outra interpretação ligeiramente diferente: «entenderam que já não eram escravos».

72 Luciano critica muitas vezes as religióes orientais, de mistério e salvação, mas ataca sobretudo os seus sacerdotes, acusados de explorarem a credulidade e a superstição das massas e de serem homossexuais.

${ }^{73}$ Literalmente: "pelo alto preço...», naturalmente em sentido irónico. Embora difícil de avaliar, parece que, dadas as condiçôes de "fim de mercado”, o preço de 30 dracmas devia ser razoável, a ponto de o narrador o considerar muito elevado... ou... nada mau. 
36. Mal chegámos ao local onde residia Filebo ${ }^{74}$ (tal era o nome do meu comprador) este bradou estridentemente da ombreira da porta: «Meniiinas! Acabo de comprar-vos um escravo, lindo, nédio e de raça capadócia ${ }^{75}$.» Ora essas "meninas", que [afinal] eram uma corja de panascas, colaboradores de Filebo, irromperam em aplausos, ao ouvirem este brado, pois cuidavam que se tratava realmente dum homem que ele tinha comprado. Quando, porém, constataram que o "escravo" era um burro, começaram a gozar com Filebo: "[Ó querida! $\left.{ }^{76}\right]$, isto náo é um escravo, mas sim um marido para ti própria. Aonde foste arranjá-lo? Oxalá tenhas uma sorte... para burro ${ }^{77}$ e dês à luz burricos chapados.»

37. E desataram a rir. No dia seguinte, conforme a sua expressão, "formaram para o trabalho" ${ }^{78}$, ataviaram a deusa e puseram-ma sobre o lombo. Depois saímos da cidade e começámos a fazer o giro da região. Cada vez que chegávamos a uma aldeia, eu, o portador da deusa, aguentava a pé firme, enquanto a troupe dos flautistas soprava freneticamente; os outros tiraram as mitras, puseram-se a tornear a cabeça abaixo do pescoço ${ }^{79}$, retalhavam os braços uns aos outros, com espadas, e depois cada um por si punha a língua exageradamente de fora [da boca] e cortava-a com os dentes, de modo que, num instante, estava tudo repleto com sangue de maricas. $\mathrm{E}$ eu, ao ver este espectáculo, ao princípio ainda me pus a tremer, não fosse a deusa ter também necessidade de sangue asinino. [Mas não:] depois de bem retalhados, começaram a receber óbolos e dracmas da assistência; outros [espectadores] davam passas de figo, um pipo de vinho, queijos, ou até um medimno ${ }^{80} \mathrm{de}$

${ }^{74}$ Literalmente, o nome do sacerdote significa «que gosta de mancebos».

${ }^{75}$ Raça afamada de burros. Na história contada por Apuleio ( $O$ Burro de Oiro), esta informação vem na altura da venda.

${ }^{76}$ [«Ó querida!»] náo está no original: serve, dalgum modo, para compensar a impossibilidade do português em marcar no verbo ("tendo arranjado») o sujeito... feminino. O tratamento no feminino era típico deste grupo sexual.

77 Literalmente: "Oxalá tenhas sorte com o casamento». Em grego, ónaio faz lembrar ónos, "burro", pelo que me permiti este brasileirismo, que traduz suficientemente o jogo de palavras do original.

78 "formaram para o trabalho": deve tratar-se de expressão militar, de que os ladróes se serviriam normalmente.

${ }^{79}$ Deve tratar-se dum ritual com gestos lânguidos, que incluíam o movimento circular do pescoço acima e abaixo dos ombros.

${ }^{80} \mathrm{C}$. de 50 litros. 
trigo ou de cevada para o burro. Era com isto que eles viviam e prestavam culto à deusa que eu transportava ao lombo.

38. Ora um dia, tendo nós entrado em certa aldeia, "caçaram" 11 um jovem aldeão, um grandalhão, e introduziram-no no local onde, na ocasiāo, estavam hospedados; depois, iam recebendo do aldeão o "tratamento" habitual e caro a estes infames panascas. Aí eu, que já tanto havia padecido com a minha metamorfose, tentei exclamar: "Ó cruel Zeus, para o que eu havia de estar guardado!» A voz, porém, que me saiu da garganta náo foi a minha própria, mas sim a do burro, e dei um zurro enorme. Ora sucedeu que uns aldeóes, tendo perdido um burro, andavam justamente à procura do animal extraviado; ao ouvirem zurrar daquela boa maneira, entraram pela casa dentro, sem dizer nada a ninguém, na convicção de que eu era o burro deles; então, surpreendem os panascas lá dentro a cometer actos inenarráveis. Estala grande risota entre os intrusos. Depois, saíram a correr e foram espalhar por toda a aldeia a história do despudor dos sacerdotes, os quais, terrivelmente envergonhados por terem sido surpreendidos em flagrante, logo nessa noite partiram dali; e mal se apanharam num local ermo do seu caminho, começaram a exprimir toda a sua irritação e raiva contra mim, por ter denunciado os seus... "mistérios" 82 . Mas se este mal, ainda assim, era tolerável (tratava-se somente de ouvir imprecações), já o que se seguiu era [absolutamente] insustentável: efectivamente, tiraram a deusa de cima de mim, colocaram-na no chão e retiraram-me toda a colchoaria; depois amarraram-me, já em pêlo, a uma árvore enorme; em seguida, deram em zurzir-me com o tal chicote ${ }^{83}$ feito de ossinhos, que por pouco não me mataram, ao mesmo tempo que me ordenavam que, daí para o futuro, me limitasse a ser um mudo transportador da deusa. $\mathrm{Na}$ realidade, haviam decidido matar-me depois da flagelação,

81 "caçaram»: é mesmo a palavra do texto grego (agreuô).

${ }^{82}$ Estas religióes tinham uma forte componente secreta, só revelada aos iniciados (os mýstai), que eram obrigados a manter o segredo dos «mistérios» (donde o sentido moderno da palavra). Neste contexto, porém, o narrador refere-se aos mistérios como sendo actos vergonhosos, o que tira ao vocábulo toda a sua carga solene e respeitável. Por isso me pareceu adequado meter, na tradução, as reticências e as aspas.

83 "... o tal chicote»: o autor desta versão abreviada (Luciano?) esqueceu-se de que não tinha anteriormente falado da existência do chicote, que vem referido na versão de Apuleio, bastante mais pormenorizada. 
por tê-los colocado na situação de serem gravemente insultados e por os ter feito sair da aldeia com o "trabalho" incompleto. No entanto, impediu-os de me matarem a ideia de deixarem a deusa vergonhosamente apeada e sem meio de transporte.

39. Portanto, depois da flagelação, tomei a Senhora [no lombo] e continuei a jornada. Já ao cair da noite, fomos ficar na propriedade dum sujeito muito rico. $\mathrm{O}$ homem estava em casa. Com o maior entusiasmo, recebeu a deusa na sua residência e celebrou sacrifícios em sua honra. Nesse local, tomei conhecimento dum grande perigo a que fiquei exposto. Efectivamente, um amigo do dono da propriedade enviara-lhe uma perna de burro selvagem. Sucedeu, porém, que o cozinheiro encarregado de cozinhá-la se descuidou com uma matilha de cães que, sem ele dar por isso, entraram lá em casa [e... era uma vez...] Então, com medo de pancadaria forte e de [outros] tormentos por ter perdido o presente, resolveu enforcar-se; mas a mulher dele - a minha má sina! - disse-lhe: «Ó querido, não te mates, não te entregues a tão grande desânimo; se me seres ouvidos, hás-de remediar a coisa: pega no burro dos panascas ${ }^{84}$, leva-o para longe, para um sítio ermo, e depois mata-o, separa-lhe essa parte, a perna, trá-la para cá, cozinha-a e serve-a ao nosso amo; quanto ao resto do burro, atira-o por qualquer precipício abaixo: julgarão que se evadiu, que se... ausentou... para parte incerta, que desapareceu, Repara como ele está bem fornecido de carne e é, em tudo o mais, mesmo superior ao outro, o selvagem.» $\mathrm{O}$ cozinheiro aprovou o plano da mulher: "Ó mulher» - disse -, «que excelente ideia... é mesmo a única forma que tenho de escapar ao chicote. Mãos à obra, já!»

Eis, pois, o que o infame do meu [... futuro $\left.{ }^{85}\right]$ cozinheiro, ali mesmo na minha cara, tramava por instigação da mulher.

40. Então eu, já antevendo a minha sorte, achei que o melhor era [tentar] safar-me ${ }^{86}$ do cutelo: rebento com a arreata a que estava atrelado, empino-me e lanço-me a galope para o local onde os panascas e o dono da propriedade estavam a cear. Irrompo por ali dentro e, tal foi o salto, que ponho tudo de pantanas, [incluindo]

${ }^{84}$ Os criados do dono da casa (homem mui piedoso) assumem a mesma visão do narrador a respeito dos sacerdotes.

${ }^{85} \mathrm{O}$ texto diz «o meu cozinheiro», naturalmente ainda só em... perspectiva.

${ }^{86}$ "tentar safar-me»: o infinitivo presente («safar-me») pode conter, em grego, além doutros valores, o de "esforço», "tentativa». Também seria legítimo traduzir por «ir tratando de me safar». 
a candeia e as mesas ${ }^{87}$. Cuidava eu ter descoberto, desse modo, um processo esperto de salvação, e que o dono da propriedade, em vista de eu ser um burro tão insolente, imediatamente ordenaria que me aprisionassem em qualquer parte e me guardassem na máxima segurança. Pelo contrário, porém, esta minha esperteza fez-me mas foi incorrer no cúmulo do perigo: julgando que eu estava danado, atiraram-se a mim com espadas, lanças e compridos varapaus, em atitude de quem ia matar-me. Dando-me conta do enorme perigo [que corria], lanço-me a toda a pressa para dentro da sala destinada a quarto dos meus amos. Então eles, ao verem isso, trancaram muito bem a porta pelo lado de fora.

41. Ao romper do dia, retomo a deusa às costas e parto na companhia dos mendigos ${ }^{88}$. Chegámos a uma outra povoação, grande e populosa, onde os fulanos inventaram uma patranha inédita: que a deusa não podia ficar numa casa particular, devendo, sim, instalar-se no templo da divindade local que ali era especialmente venerada. Os da terra ficaram exultantes por receberem a deusa estrangeira e puseram-na em companhia da sua própria deusa; quanto a nós, atribuíram-nos uma casa de gente pobre. Nessa povoação passaram os meus donos bastantes dias, após o que decidiram partir para a cidade vizinha, pelo que pediram a deusa aos da terra; eles próprios entraram no templo e foram buscá-la; depois puseram-na em cima de mim e partiram. Sucedeu, porém, que aqueles grandes ímpios, aquando da sua entrada no referido templo, roubaram uma taça sagrada, em ouro, que levaram escondida na [roupagem da] deusa. Ora os aldeóes, ao darem pela coisa, puseram-se imediatamente em sua perseguição. Logo que os alcançaram, desceram dos cavalos, interrompem-lhes a marcha e começam a chamar-lhes ímpios e sacrílegos; depois revistaram tudo, até que deram com a taça no seio da deusa. Em vista disso, amarraram os maricas, trouxeram-nos pelo mesmo caminho e pregaram com eles na prisão; quanto à deusa que eu transportava, carrega-

87 "as mesas»: notar que as mesas serviam de apoio aos pratos que iam sendo servidos, pois as pessoas comiam reclinadas em leitos.

${ }^{88} \mathrm{Ou}$ "mendigantes»_o texto diz apenas agýrtes, "mendigo», mas também "charlatão", "saltimbanco». O termo técnico, e sem carga pejorativa, para designar os sacerdotes itinerantes (e pedintes) da Deusa-Mãe (e doutras divindades similares) era metragýrtes, i. é, «mendigantes da (Deusa-) Mãe». Com a designação abreviada, o narrador pretende desprestigiar a função religiosa. 
ram com ela e entregaram-na a um outro templo; e quanto ao objecto de ouro, devolveram-no à deusa padroeira da cidade.

42. No dia seguinte, resolveram pôr à venda os apetrechos [do culto ${ }^{89}$ ], mais a minha pessoa; entregaram-me a um tipo, um forasteiro que residia na aldeia próxima e que era padeiro de sua profissão ${ }^{90}$. Este tomou conta de mim e, uma vez que tinha comprado dez medimnos ${ }^{91}$ de trigo, pôs-me o trigo no lombo e foi andando para casa, por um caminho difícil. Aí chegados, introduz-me no moinho, onde deparo com uma grande quantidade de bestas, companheiras de escravidão. Havia muitos engenhos de moer, e todos estavam, [na altura,] a ser movidos por estes [animais]; havia farinha por todo o lado. Naquele dia, atendendo a que o escravo vinha de fora, que já carregara com um fardo pesadíssimo e acabava de chegar duma jornada difícil, deixaram- $\mathrm{e}^{92}$ a descansar lá dentro; mas no dia seguinte puseram-me uma venda nos olhos, atrelaram-me à barra do engenho e... toca a andar. Eu, porém, embora soubesse, por já ter larga experiência ${ }^{93}$, como é que se mói, fingia desconhecer... mas saíram-me as contas furadas: em grande número, os [trabalhadores] do moinho pegam em cacetes, póem-se de volta de mim e, mal me precato (pois náo via nada), zurzem-me valentemente, todos à uma, de modo que, tanta era a porrada, pus-me imediatamente a girar como um pião: é que a experiência tinha-me ensinado que, no cumprimento do dever, o escravo não deve esperar pela mão do senhor.

43. Por conseguinte, dou em emagrecer muito e em ficar fraco de forças, de modo que o meu dono resolveu vender-me, entregando-me a um sujeito que era hortelão de seu ofício. Este fulano, de facto, tomara [de renda] uma horta para cultivar. Eis em que consistia o nosso trabalho: de madrugada, o meu dono punha-me no lombo a hortaliça, levava-a ao mercado, entregava-a aos vendedores e trazia-me novamente para a horta. Depois, enquanto ele cavava,

${ }^{89} \mathrm{Na}$ realidade, tà skéuê significa, em sentido lato, «os objectos», que incluíam apetrechos de culto, roupas, vasos, e até os pertences pessoais.

${ }^{90} \mathrm{O}$ texto diz, de forma descritiva, «... e que tinha como profissáo amassar pão".

${ }^{91}$ Se o medimno equivalia, de facto, a 50 litros, temos aqui uma carga de 500 quilos... que logo a seguir se reconhece ser «um fardo pesadíssimo».

92 Aqui e a seguir, os verbos no plural indicam claramente que está incluído o pessoal das mós.

93 "por já ter larga experiência»: naturalmente como homem. 
semeava e regava ${ }^{94}$, eu, nesse entretanto, ficava à boa vida. Apesar disso, porém, aquela vida era-me terrivelmente penosa: antes de mais, porque já era Inverno e o meu dono náo podia comprar uma manta para ele, quanto mais para mim; depois, andava desferrado, pisando lama muito aguada e gelo duro e aguçado; além disso, como único alimento para ambos, tínhamos alfaces amargas e rijas.

44. Ora uma vez, íamos nós a caminho da horta, e eis que nos surge um homem [todo] garboso, vestido com uniforme militar, e que se dirige a nós, primeiro ${ }^{95}$ em latim, perguntando ao horteláo aonde ia com o burro (ou seja, comigo). O meu dono, porém (creio que por náo entender a língua), não lhe deu qualquer resposta, pelo que o tipo, furioso com o aparente descaso, bate com o chicote no hortelão, o qual, [por sua vez,] se pega com o outro, passa-lhe uma rasteira e estende-o por terra, ao comprido; depois, com ele assim deitado, vá de bater-lhe com os punhos, com os pés e com uma pedra que apanhara do chão. Ao princípio, o homem ainda estrebuchava, ameaçando-o de que, mal se levantasse, o mataria com o sabre. Aí, o meu dono, avisado pelo próprio [adversário], tira-lhe o sabre, por medida de precauçáo, e lança-o para longe, após o que recomeçou a bater no prostrado. Este, vendo que não podia mais aguentar os maus tratos, finge-se de morto de tanta pancada. O outro, então, aterrorizado com o sucedido, deixa-o ali mesmo onde ele jazia, pega no sabre, salta para cima de $\operatorname{mim}^{96}$ e parte para a cidade.

45. Assim que lá chegámos, confiou o cultivo da horta a um seu ajudante e, receando o perigo de voltar pelo mesmo caminho, vai esconder-se, juntamente comigo, em casa de um dos seus amigos na cidade. No dia seguinte, conforme resolução [tomada], procedem deste modo: ao meu amo, esconderam-no dentro duma arca, e a

94 «regava»: literalmente, «levava água às plantas». Não se trata, pois, de rega por aspersão (com regador...), mas do conhecido e antigo método de encaminhar a água por regos.

95 "primeiro em latim»: o autor desta versão resumida esquece-se, na sequência, de referir a mudança de idioma. De facto, em $O$ Burro de Oiro de Apuleio $(9,39)$, o soldado romano, vendo que o horteláo não entendia latim, fala-lhe em grego. Luciano (?), porém, tem pressa de dar início à rixa que se segue.

96 Segundo a tradução inglesa da Loeb (vol. VIII, p. 123), o hortelão pôs a espada no lombo do burro e partiu para a cidade (gave me the sword to carry and went off to the city). Não concordo, mas era algo longo de explicar... 
mim içaram-me escada acima ${ }^{97}$, para um compartimento no andar superior, onde me encerraram. Ora o soldado, lá conseguindo, a muito custo, levantar-se do cháo, chegou à cidade, segundo nos disseram ${ }^{98}$, atordoado com a sova. Vai ter com os seus camaradas e relata-lhes o comportamento furioso do hortelão. Vão daí, com o seu companheiro, e descobrem o local onde estávamos escondidos. Foram ter com as autoridades da cidade, que mandaram um funcionário ir lá a casa, com ordem de fazer sair os moradores para a rua. E de facto saíram, mas do horteláo nem sombra. Os soldados, porém, garantiram que o horteláo estava lá dentro, bem como eu, o burro deste; mas os outros sustentavam que não tinha lá ficado fosse quem fosse, nem homem nem burro. Com o burburinho e a algazarra que se haviam gerado na ruela, eu, assomadiço e eterno curioso, movido pelo desejo de saber quem estava aos berros, meto [o pescoço] pelo postigo e espreito lá de cima cá para baixo. Então os tipos viram-me e puseram-se logo a gritar. Os outros, apanhados em falso, foram presos; as autoridades penetraram no interior [da casa], vasculharam tudo e encontraram o meu amo deitado dentro da arca; pegaram nele e mandaram-no para a cadeia, a fim de prestar contas das suas façanhas; e quanto a mim, carregaram-me cá para baixo e entregaram-me aos soldados. Foi uma risota geral e despegada à custa daquele que, do andar de cima, denunciara e traíra o próprio senhor. E foi daí, desse episódio passado comigo, que nasceu, entre as gentes, o provérbio: "Só pelo descuido dum burro. ${ }^{99}$ "

46. No dia seguinte... Bem: o que sucedeu ao hortelão meu amo, não sei; a mim, porém, o soldado resolveu pôr-me à venda e, de facto, vende-me por vinte e cinco [dracmas] áticas. Ora, o tipo que me adquiriu era criado dum sujeito muitíssimo rico de Tessalonica, a maior cidade da Macedónia; o seu ofício consistia em preparar as refeiçôes para o seu amo; e tinha um irmão a servir na mesma casa, o qual estava encarregado de cozer o pão

97 Trata-se duma "escada de mão», e não duma escada fixa (de pedra, madeira...). Este era o processo mais comum de acesso aos andares superiores.

98 "segundo nos disseram»: há quem ligue a expressão a «levantar-se», mas parece mais lógico que se refira a "atordoado», pois deve tratar-se do testemunho de pessoas da cidade, que, essas sim, viram chegar o soldado ainda atordoado.

${ }^{99}$ É difícil traduzir este provérbio, que se refere (parece!) a casos em que uma pessoa, por uma ninharia ou motivo fútil, ficava em situaçáo delicada. Talvez "por uma coisa que não vale um caracol», mas, neste contexto, é imperioso manter a referência ao burro. 
e amassar bolinhos de mel ${ }^{100}$. Estes dois irmãos tinham mesa em comum, dormiam na mesma casa e possuíam também em comum a ferramenta dos seus ofícios. Nesta ordem de ideias, instalaram-me, também a mim, na casa onde pernoitavam. Depois da ceia do amo, ambos traziam para casa uma grande porção de sobras: um [trazia] carne e peixe, o outro pão e bolos. Depois, fechavam-se na sala com estas [iguarias], de cuja guarda, aliás agradabilíssima, me encarregavam, e iam tomar banho. Então eu, mandando ao diabo $^{101}$ a cevada que me serviam, atirava-me mas era ao produto (e pagamento) dos ofícios dos meus amos e, com todo o vagar, enchia a barriga com comida da gente. E eles, ao regressarem à sala, a princípio náo se apercebiam da minha gulodice, quer devido à abundância [de comida] à sua disposiçáo, quer ainda porque eu roubava a minha refeição ${ }^{102}$ a medo e com parcimónia. Então eu, ao constatar essa sua completa ignorância, dei em devorar os melhores pitéus, aliás em grande quantidade. Quando, porém, começaram a aperceber-se da «razia», a princípio olhavam ambos desconfiados um do outro; depois, chamavam-se um ao outro ladráo, rapinador de bens comuns e desavergonhado; por fim, tornaram-se ambos meticulosos e deram em fazer a contagem das doses.

47. Eu, é claro, levava uma vida de prazer e de luxo; e assim, por via da comida normal [ao ser humano], o corpo ia recuperando a sua beleza, e a minha pele, com a [nova] pelagem a despontar, até brilhava. Ora, os meus "caros amigos», vendo-me gordo e anafado (e isto sem que a cevada aparecesse consumida, mas sempre no mesmo nível), começaram a suspeitar das minhas façanhas; então, [uma vez], saíram como se fosse para o banho e fecharam a porta... mas ficaram à espreita por uma fresta, a observar o que se passava no interior. E eu, sem me dar conta da manha, fui-me ao almocinho. A princípio, os fulanos não faziam senão rir, ao verem um almoço incrível, mas depois foram chamar os outros criados seus colegas, para assistirem a este espectáculo. Gerou-se enorme risota, a ponto de o patrão ouvir as gargalhadas (tal era a algazarra que vinha da

${ }^{100} \mathrm{O}$ texto parece demasiado restritivo. Talvez fosse preferível traduzir, sem mais, por "era padeiro e pasteleiro".

${ }^{101}$ Lit. $^{\text {te }}$ "dizendo um longo adeus» ou «... passem lá muito bem».

102 "refeição»: em rigor, a palavra grega significa «almoço», mas, nisto de refeiçóes, as várias designaçóes nem sempre mantiveram o seu sentido inicial. Neste passo, ainda poderíamos dizer que, para o burro, esta era, na realidade, a primeira (e única!) refeiçáo do dia. Mas temos outros exemplos de áriston como refeiçáo do meio do dia e até da noite (ceia). 
rua); e perguntou que raio era aquilo de que estavam a rir daquela boa maneira. Ao ouvir [do que se tratava], levanta-se da mesa, vem espreitar [pela fresta] e vê-me a devorar uma peça de porco bravo. Então, desata a rir às gargalhadas e irrompe pela sala dentro. Eu é que fiquei atrapalhado, ao ser surpreendido, diante do senhor, como gatuno e glutáo ao mesmo tempo. Ele, porém, achou-me muita graça e, para começar, deu ordem de me conduzirem à sua sala de jantar; depois, mandou porem-me a mesa, e sobre ela uma grande variedade de iguarias, daquelas que, para qualquer outro burro, eram impossíveis de tragar: carne, marisco, caldos, peixe... uns temperados com salmoura e azeite, outros cobertos de mostarda. $\mathrm{E}$ eu, vendo que a sorte agora me sorria docemente, e dando-me conta de que só com esse «jogo» me safaria, muito embora estivesse já a abarrotar, assim mesmo, pus-me à mesa e comecei a cear ${ }^{103}$. A sala estalava de riso, quando alguém disse: «Este burro também há-de beber vinho, desde que lho diluam ${ }^{104}$ e lho sirvam.» Então o senhor deu ordens nesse sentido, e eu bebi o [vinho] que me trouxeram.

48. Ora o senhor, naturalmente vendo que eu constituía uma aquisição extraordinária, ordenou a um dos seus administradores que pagasse ao que me havia comprado o preço que este dera por mim, mais outro tanto, e confiou-me aos cuidados de um dos seus jovens libertos ${ }^{105}$, dizendo-lhe que me amestrasse em todas as habilidades com que eu mais pudesse diverti-lo - tudo coisas fáceis para o jovem, pois eu, à medida que recebia as ordens, a todas obedecia de pronto. Para começar, obrigou-me a reclinar-me no leito, apoiado no cotovelo, tal como uma pessoa ${ }^{106}$; seguidamente, pôs-me a lutar com ele, e até mesmo a dançar, muito direito, empinado sobre as duas patas de trás; depois, mandou-me responder [com a cabeça] «sim» ou «não» às suas questôes... enfim, tudo coisas que eu era capaz de fazer sem que mas ensinassem. Espalhou-se a

103 "cear»: lit. "e "almoçar», v. nota supra.

${ }^{104}$ Normalmente, o vinho era bebido misturado com água, no momento de servir. Só os grandes ébrios o bebiam puro. A referência a "diluir» pode, pois, soar estranha ao leitor moderno, mas era a coisa mais natural deste mundo. Imagine que, em grego posterior, a palavra oinos «vinho» foi substituída por krasí, que, etimologicamente, significa «mistura».

${ }^{105}$ Os povos das províncias orientais do Império Romano, embora mais ou menos helenizados do ponto de vista cultural, estavam sujeitos às categorias jurídicas e sociais do direito romano. O liberto era um ex-escravo que havia beneficiado da liberalidade do senhor, mas continuava ligado à família».

${ }^{106}$ É esta a posição do comensal, e não, como hoje, a de "sentado à mesa". 
notícia do burro do senhor, um burro que bebia vinho, que lutava e dançava e que - maravilha das maravilhas - respondia «não» e "sim», com a-propósito, às palavras [das pessoas]. Sempre que queria beber, dava um safanáo no escanção e pedia-lhe com um gesto de olhos. As pessoas ficavam maravilhadas com este fenómeno extraordinário, desconhecendo que, sob a aparência dum burro, estava um ser humano. Eu, é claro, aproveitava-me regaladamente da sua ignorância. Além disso, aprendi a marchar a passo, a levar o senhor no dorso e a correr a galope - um galope tấo macio, que o cavaleiro nem o sentia. Possuía também um equipamento de luxo, cobriam-me com mantos de púrpura, presenteavam-me com freios bordados a prata e ouro e penduravam-me [ao pescoço] uns guizos que emitiam um som suavemente harmonioso.

49. Ora, Ménecles, o nosso amo, tinha-se deslocado, conforme já referi, de Tessalonica a esta terra. O motivo era o seguinte: havia-se comprometido a oferecer à sua cidade natal um espectáculo de homens especializados em lutarem armados uns contra os outros em combates singulares ${ }^{107}$. E de facto, os homens já estavam em plena preparação para o combate, pelo que chegara o momento da partida. Portanto, logo de madrugada, pomo-nos a caminho; e sempre que surgia um troço de estrada mais rude e as carruagens tinham dificuldade em passar, era eu que carregava com o senhor. Ao chegarmos a Tessalonica, náo houve ninguém que não viesse a correr, a fim de apreciar o espectáculo e ver a minha pessoa; sim, que a minha fama já me havia precedido lá de tão longe, [nomeadamente] a versatilidade e a humanidade das minhas danças e lutas ${ }^{108}$. O senhor, porém, só me exibia, durante o beberete, aos mais distintos dos seus concidadãos, aos quais, nesse período da ceia, apresentava as minhas famosas habilidades.

50. O meu treinador, porém, inventou, à minha custa, uma fonte de rendimento de muitíssimas dracmas: mantinha-me encerrado dentro de casa, e só mediante pagamento facultava a entrada a quem quisesse ver-me, a mim e às minhas extraordinárias habilidades. As pessoas traziam comida, cada uma sua coisa, mas sobretudo aquilo que mais lhes parecia repugnar a um estômago de burro. E eu ia comendo, de tal forma que,

${ }^{107}$ É tradução literal, talvez demasiado descritiva, que poderíamos simplificar: «... um espectáculo de gladiadores especializados em combates singulares».

${ }^{108}$ Rigorosamente, trata-se de simulacros de lutas. 
tomando refeiçóes com o meu amo e com as pessoas da cidade, em poucos dias fiquei gordo e espantosamente anafado.

Ora, certa vez, uma mulher estrangeira, senhora duma fortuna nada medíocre e bastante bela, tendo entrado na sala para me ver comer, apaixonou-se ardorosamente por mim e entrou em desejo de ter relaçóes comigo, não só devido à beleza do burro, mas também pela bizarria dos meus hábitos. Entende-se, pois, com o meu treinador, prometendo-lhe uma recompensa choruda, se ele a deixasse dormir aquela noite comigo. $\mathrm{O}$ homem, tanto se lhe dando que ela conseguisse ou não alguma coisa de mim, aceitou o pagamento.

51. Como já era de noite e o nosso amo nos tivesse dado licença de sair da sala de jantar, retirámo-nos para o quarto onde costumávamos dormir, e demos lá com a mulher, que já tinha chegado há muito e estava à beira da minha cama. Tinham-lhe trazido uns travesseiros fofos e posto cobertores; enfim, havia uma cama no chão, preparada para nós. Depois, os criados da mulher foram dormir para um local próximo, em frente do quarto, enquanto ela acendia uma candeia enorme, que brilhava como uma fogueira. Em seguida, despiu-se e, assim toda nua, aproximou-se da candeia, deitou perfume de um frasquinho de alabastro, untou-se com ele e perfumou-me também a mim, embebendo-me especialmente o focinho; depois, beijou-me, pôs-se a falar comigo como se eu fosse um seu amante homem, pegou-me pela arreata e puxou-me para a cama no chão. $\mathrm{E}$ eu, que [aliás ${ }^{109}$ ] não precisava que ninguém me convidasse para a função, que, [além disso], já estava um tanto ou quanto "pingado" com grande quantidade de vinho velho, e, [para mais], excitado pela esfregadela do perfume, e, [finalmente], perante uma "garota" toda boa ${ }^{110}$, baixo-me... mas [o caso é que] estava seriamente embaraçado com a forma de "montar» a criatura. É que, realmente, desde que estava transformado em burro, nunca me acontecera ter um contacto habitual com burros, e muito menos ter relações íntimas com uma burra. Além disso, uma coisa me causava um receio nada pequeno: que a mulher, por falta de "espaço», ficasse desfeita, e eu viesse a ser exemplarmente punido por homicídio. Não sabia eu que esse era um receio sem fundamento, pois a mulher provocava-me com muitos beijos, por sinal bem eróticos; e assim que viu que eu já não tinha mão em

109 [«aliás... além disso... para mais... finalmente»]: o texto grego é mais sóbrio: «e... e...e...»

${ }^{110}$ Literalmente: «boa (ou: «bela») em todo o sentido». 
mim, deita-se a meu lado como se eu fosse um homem, abraça-me, introduz [a "coisa»] e recebe-a em pleno. E eu, coitado, ainda receoso, tentava retirar-me suavemente, mas a fulana atracou-se-me [com tanta força] ao lombo, que eu não podia retrair-me: ela mesma ia atrás do "fugitivo». Quando, enfim, me convenci completamente a colaborar no prazer e na satisfação da mulher, a partir daí, comecei a «aviá-la» sem meias medidas e tendo para comigo que não ficava a dever nada ao amante de Pasífae ${ }^{111}$. Mas o facto é que a mulher se revelou táo propensa às coisas de amor e táo insaciável nos prazeres do coito, que gastou ${ }^{112}$ toda a noite comigo.

52. De manhã, levantou-se e saiu, mas primeiro ajustou com o meu treinador pagar-lhe, por noite, a mesma quantia por idêntico serviço. E ele, na mira de enriquecer à minha custa e, simultaneamente, mostrar ao seu amo uma nova habilidade minha, vai-me deixando fechado com a mulher, a qual, no entanto, abusava terrivelmente de mim... Até que um dia, o meu treinador vai participar ao amo a minha proeza, como se fosse ele próprio quem ma tivesse ensinado. E, sem que eu o soubesse, condu-lo, pela noitinha, ao local onde eu dormia e, por uma fresta da porta, mostra-me, lá dentro, enrolado na cama com a tipa. Entáo ele, deleitado com o espectáculo, concebeu o desejo de me apresentar também em público nesta actividade, e deu ordem [ao criado] para que não dissesse nada a ninguém sobre o caso, «a fim de que» - disse - «no dia do espectáculo, o levemos ao anfiteatro com uma dessas mulheres condenadas e, à vista de toda a gente, ele cubra a mulher». E manda vir para junto de mim uma das tais mulheres, que estava condenada às feras, ordenando-lhe que se aproxime de mim e me faça festas.

53. Chegado, finalmente, o dia em que o meu amo tinha de inaugurar os jogos, resolveram levar-me ao anfiteatro, onde dei entrada com o seguinte aparato: havia uma liteira grande, feita de tartaruga indiana e cravejada a ouro; reclinaram-me nela e, a meu lado, fizeram reclinar também a mulher. Em seguida, e nessa posição, colocaram-nos sobre uma maquineta ${ }^{113}$, empurraram-na

${ }^{111}$ Pasífae, mulher de Minos, rei de Creta, apaixonou-se por um touro... donde nasceu o célebre Minotauro.

112 "gastou» é tradução literal, que entendi manter. O verbo, em sentido próprio, significa exactamente "gastar», "fazer despesa».

113 Devia tratar-se de um veículo com rodas, que, numa espécie de palco, transportava a liteira com os amantes. Espectacular, sem dúvida. 
até ao interior do anfiteatro e depuseram-nos no centro. As pessoas soltavam um clamor estrondoso, e sobre mim caiu uma salva de palmas geral; ao nosso lado tinham posto uma mesa, sobre a qual se via de tudo o que as pessoas finas comem à ceia; uns belos rapazes assistiam-nos na qualidade de escançôes, servindo-nos o vinho em copa de oiro. Entáo o meu treinador, colocado atrás de mim, instava-me a comer; eu, porém, estava envergonhado de me ver assim reclinado em pleno anfiteatro, e, ao mesmo tempo, receava que (sei lá... ${ }^{114}$ ) algum urso, ou um leáo, me saltasse em cima.

54. Nisto, passa por mim alguém que levava umas flores ${ }^{115}$; entre a variedade dessas flores, vislumbro uma pétalas de rosas viçosas. Sem a mínima hesitação, dou um salto para o ar e precipito-me do leito para fora. As pessoas julgaram que eu me levantava para dançar, mas eu lanço-me em corrida sobre as flores, escolho de entre elas as rosas e ponho-me a devorá-las uma por uma. Ainda as pessoas estavam boquiabertas com o que eu fizera ${ }^{116}$, e eis que me cai, e logo se desvanece, aquele envelope exterior de besta: desaparece o famigerado burro de há tão longo tempo e fica, ali especado e todo nu, o autêntico Lúcio que estava lá dentro. À vista deste espectáculo estranho e nada esperado, ficou toda a gente estupefacta e num tumulto doido; dividiu-se a assistência em duas facçóes: uns achavam que eu era um [bruxo] especialista em drogas temíveis e nos malefícios da metamorfose, pelo que devia morrer imediatamente na fogueira; outros, porém, aconselhavam a que se aguardassem as minhas alegaçôes, antes de julgarem, e só depois fosse emitida sentença sobre o caso. Então eu... corro na direcção do governador da província, que por acaso assistia a este espectáculo, e, cá de baixo, [da arena,] contei-lhe que uma mulher da Tessália, criada duma [outra] mulher [também] da Tessália, me besuntara com um unguento mágico, transformando-me em burro; e roguei-lhe que me detivesse e me mantivesse na prisão, até poder provar-lhe que náo estava a mentir e as coisas se tinham passado assim.

${ }^{114}$ A partícula pou dá justamente a ideia de algo indefinido, mas real, i. é )neste caso) um perigo iminente, que o burro-narrador imagina possa ser um urso, ou um leáo... ou...

${ }^{115}$ Em O Burro de Oiro, de Apuleio, o final da história é completamente diferente.

116 Embora a ingestão de rosas não constasse do "programa das festas", o facto acaba por ser, aos olhos dos espectadores, mais um motivo de espanto. Do ponto de vista narrativo, trata-se do elemento que, finalmente, conduz a história ao seu termo. 
55. Então o governador respondeu: «Diz-nos o teu nome, dos teus pais e familiares ou quaisquer outros parentes de sangue, e ainda a tua terra natal.»

Retorqui: «Meu pai chama-se [Fulano de Tal ${ }^{117}$ ], eu chamo-me Lúcio e tenho um irmão de nome Gaio; quanto ao apelido [paterno], temos ambos o mesmo; sou autor de histórias ${ }^{118}$ e doutras obras [em prosa], enquanto ele é poeta elegíaco e excelente adivinho ${ }^{119}$. A nossa terra natal é Patras, na Acaia.»

Ao ouvir estas palavras, o magistrado disse: «[Sendo assim,] és filho de pessoas amicíssimas minhas, de hospedeiros ${ }^{120}$ que me receberam em sua casa e me honraram com presentes; tenho, pois, a certeza de que, filho de tal gente, não estás a mentir.» E, levantando-se do assento, abraça-me, beija-me efusivamente, e já mesmo me ia conduzindo a sua própria casa. Nesse entrementes, porém, chegou meu irmão, que me trazia dinheiro e muitas coisas mais. Em vista disso, o governador despede-se [ali mesmo] de mim, oficialmente e na presença do povo. Dirigimo-nos à zona do porto, procurámos um navio e carregámos para bordo a nossa bagagem.

56. No entanto, tive por bem ir visitar aquela mulher que se apaixonara por mim quando burro: cuidava eu que agora, com forma humana, lhe pareceria ainda mais belo. Ela, de facto, ficou não só contente por me receber e, julgo eu, encantada com o extraordinário acontecimento, como até me rogou que ceasse com ela e dormisse [lá em casa ${ }^{121}$. Eu acedi, considerando que seria merecedor de castigo divino que, burro outrora amado, agora, tornado homem, me fizesse "caro» e desprezasse

${ }^{117}$ Os manuscritos omitem o nome do pai, que a personagem devia indicar pelo nome próprio, mais (e especialmente) o apelido ou nome de família (nome gentílico). Naturalmente, Lúcio e seu irmão Gaio teriam o mesmo nome gentílico, que não era necessário repetir, depois de se ter declarado o do pai. A omissão do nome de família pode ser propositada, já que acrescentaria à história uma realidade difícil de assumir.

${ }^{118}$ Dois sentidos possíveis: a) "obras de História», "historiografia»; b) «novelas», «romances» ou "histórias» já em sentido moderno.

${ }^{119}$ A palavra grega, mántis pode interpretar-se também por "profeta». De toda a maneira, o irmáo do narrador, além de poeta elegíaco, desempenhava também uma função religiosa.

${ }^{120}$ As leis (não escritas) da hospedagem ligavam fortemente pessoas de terras diferentes.

${ }^{121} \mathrm{O}$ texto permite outra interpretação: «... que ceasse e dormisse com ela». É bem possível (e até muito provável) que a mulher quisesse dizer uma coisa, e que Lúcio, naturalmente, entendesse outra. 
a [antiga] apaixonada. Ceio, pois, com ela, besunto-me com uma grande camada de perfume e coloco uma coroa de rosas aquelas flores tão queridas, que me haviam restituído ao convívio humano. Como a noite já ia adiantada e se fazia tempo de ir dormir, eu levanto-me e, cuidando fazer "grã cousa", dispo-me e ponho-me de pé, todo nu [diante dela], no pressuposto de que assim, por simples comparação com o burro, ainda mais lhe agradaria. Ela, porém, ao ver que eu tinha tudo dum homem, escarrou-me na cara, dizendo: "Raios te partam! Sai de ao pé de mim e de minha casa e vai dormir para bem longe daqui.»

E tendo-lhe eu perguntado: "Mas que ofensa tão grande te fiz eu?», respondeu: «É que, por Zeus!, quem eu amava náo era a tua pessoa, mas sim o burro que tu eras; com esse, e não contigo, é que eu dormia; cuidava que tu ainda tivesses conservado e trouxesses contigo pelo menos aquele singular e enorme símbolo do burro, mas, em vez disso, apareces-me aqui feito macaco, tu que eras aquele tão lindo e útil animal.»

E imediatamente chama os criados e ordena-lhes que me levam às costas, de "charola», para fora de casa. Assim expulso da sala, no meio da rua, todo nu e lindamente engalanado e perfumado, abraçado à terra nua, com esta passei a noite. Ao romper de alva, corri, em pêlo, para o navio e conto ao meu irmão a ridícula desventura.

Zarpámos imediatamente da cidade, aproveitando o vento favorável que soprava; e em poucos dias chego à minha terra natal, onde celebrei um sacrifício e consagrei um ex-voto aos deuses salvadores, pelo facto de, graças a Zeus ${ }^{122}$, passado tão longo e difícil tempo, ter regressado a casa, salvo, náo do... (como diz a fábula)... do cu do cão ${ }^{123}$, mas da cu...riosidade do burro.

${ }^{122} \mathrm{O}$ original diz «por Zeus!». A tradução pretende (talvez indevidamente) acrescentar uma conotação moderna ("graças a... Deus») algo risonha.

${ }^{123}$ No original, o jogo é apenas de ideias: «... salvo, não do cu do câo (como diz o provérbio), mas da curiosidade do burro». Aliás, a palavra periergía significa não apenas curiosidade «curiosidade», mas também, no tempo de Luciano, «interesse pela magia», "prática da magia», "artes mágicas», "magia». $\mathrm{O}$ jogo de palavras da tradução pretende, de algum modo, compensar a falta de compreensão do provérbio, cujo sentido nos escapa. Que o leitor me desculpe, mas, por vezes, uma pequena traição aos originais sabe pelos dias da vida. 
UMA HISTÓRIA VERÍDICA 
(Página deixada propositadamente em branco) 


\section{UMa HistóRIa Verídica}

\section{INTRODUÇÃo}

Como já disse noutros locais, no conjunto da produção literária de Luciano destacam-se, por contraste, algumas obras de fantasia, de ficção pura, mas que não deixam, por isso, de constituir uma imagem do mesmo homem que escreveu os Diálogos (Diálogos dos Mortos, Diálogos dos Deuses, Diálogos dos Deuses Marinhos, Diálogos das Cortesäs, etc.). Além de Lúcio ou O Burro ${ }^{124}$ e Icaromenipo, temos aqui de salientar Uma História Verídica.

Quem ler os variados escritos de Luciano notará, como linha de força constante, a sua capacidade de divertir enquanto fala a sério... mas também o contrário: a sua capacidade de falar a sério, para lá da aparência jocosa de certas obras. De facto, por vezes não sabemos se a intenção fundamental vai num ou noutro sentido - e daí que certos críticos censurem, com demasiada insistência, uma superficialidade que, em meu entender, é apenas... superficial.

Em Uma História Verídica, porém, o A. parece pretender, sobretudo, divertir. Se critica os autores de ficção, fá-lo apenas em certo sentido moral: eles não deveriam tentar enganar o público, fazendo passar por autêntico o que era manifestamente inventado. De resto, reconhece-lhes o direito de fantasiar. Em todo o caso, tal crítica fica, duma vez por todas, consignada no prólogo. Ele, Luciano, procede com mais limpidez e lisura:

"Já que não tinha nada de verídico para narrar, ... virei-me para a mentira, mas uma mentira mais desculpável que a daqueles, porquanto numa coisa serei eu verdadeiro: ao confessar que minto. Desta forma, isto é, declarando que não digo nem uma ponta de verdade, creio ficar absolvido da acusação que porventura me façam. Escrevo, pois, sobre coisas que não testemunhei nem experimentei, e que não soube da boca doutrem; mais ainda: que não existem em absoluto e que, de qualquer forma, não são susceptiveis de ocorrer. Portanto, não deve o leitor dar o minimo crédito às minhas histórias." (\$ 4)

De quem assim se exprime, tudo é de esperar. E de facto, Luciano não nos desilude: dando rédea solta à sua fantasia,

124 Trad. Clássicos Inquérito, no 22, com o título Eu, Lúcio - Memórias de um Burro 
faz-nos embarcar (é o termo) numa aventura louca, num longo cruzeiro, destinado a ser de estudo, mas que se transforma, logo de início e numa sequência diabólica, em peregrinação aventurosa por vários Países de Maravilha. Sim, pensemos na Alice, no Gulliver, em Cyrano de Bergerac, em Rabelais, no Voltaire do Micrómegas, nos contos tradicionais de todos os países... e até nos produtos (e alguns, porventura muitos, subprodutos) da moderna banda desenhada e dos filmes de animação e de ficção. Do ponto de vista da fantasia, Luciano não fica a dever nada a nenhum deles. De qualquer forma, Uma História Verídica apresenta-se com a frescura das coisas novas, muito embora Luciano não tenha, como ele próprio confessa, inventado a literatura de ficção.

O leitor julgará por si, mas certamente se aperceberá de que certas noçóes como a de bom senso, a de extravagância, e outras da semântica convencional, não se aplicam ao nosso contista.

Quanto a mim, Uma História Verídica constitui um dos mais espantosos espécimes de fantasia à solta. Creio que, posta em banda desenhada, ganharia uma certa dimensáo e um certo sabor... visual. À consideração de algum editor...

Bom senso, extravagância... Que é isso? 


\section{UMA HisTóRIA VERÍdica}

\section{Livro I}

1. Assim como os atletas e, dum modo geral, os que se ocupam da preparação física, não cuidam exclusivamente da sua boa forma e dos exercícios, mas igualmente do repouso feito a tempo (o qual, aliás, consideram uma parte importantíssima do treino), assim também me convenço de que os intelectuais, após um longo período de leituras sérias, têm toda a vantagem em relaxar o espírito, tornando-o, desse modo, mais forte para o trabalho futuro.

2. Ora, o próprio repouso poderia até tornar-se-lhes agradável, se porventura se entregassem a um género de leitura que, além de proporcionar um entretenimento simples, como é o que resulta duma temática jocosa e divertida, suscitasse também alguns motivos de reflexão que náo desconvêm às musas — algo parecido, suponho, com o que porventura sentirão ao lerem esta minha obra. Efectivamente, o que nela os seduzirá reside náo apenas na estranheza do tema, , ou na minha intençáo de divertir, ou no facto de eu ter inventado mentiras variadas que têm todo o ar de verosimilhança e de verdade, mas igualmente na circunstância de, à laia de paródia, cada passo da narrativa fazer alusão a certos poetas, prosadores e filósofos, que nos deixaram obras fantásticas e cheias de imaginação — autores esses cujos nomes eu explicitaria, se a simples leitura não bastasse para que tu próprio ${ }^{125}$ os identificasses ${ }^{126}$.

3. [A título de exemplo: $\left.{ }^{127}\right]$ Ctésias de Cnido, filho de Ctesíoco, escreveu, a respeito da Índia e das suas curiosidades, coisas que nem ele próprio testemunhara, nem ao menos tinha ouvido da boca de pessoa fidedigna. Também Iambuco escreveu muita coisa maravilhosa sobre o grande $\operatorname{mar}^{128}$, com o que fabricou

125 "tu próprio»: Luciano deve dirigir-se a algum amigo, mas também podemos imaginar um qualquer leitor como destinatário da obra.

${ }^{126}$ Luciano não podia adivinhar que a maior parte do que ele ainda podia ler da literatura antiga viria a perder-se nos séculos seguintes.

127 [...] Esta expressão não está no original, mas apenas implícita.

${ }^{128}$ Referência ao Oceano Atlântico, muito mal conhecido, a que no $\$$ 5 chama «oceano ocidental». 
uma mentira que não engana ninguém; mas a história que ele conta nem por isso é menos divertida. E muitos outros deram a sua preferência a temas do mesmo género, escrevendo sobre peregrinaçôes e viagens que pretensamente teriam realizado e contando histórias de animais gigantescos e de povos selvagens com os seus estranhos costumes. Mas quem lhes serviu de guia e mestre neste tipo de charlatanices foi o Ulisses de Homero, o qual, na corte de Alcínoo, contou histórias de ventos aprisionados, de seres com um só olho, de canibais e de povos selvagens, enfim, de animais de muitas cabeças e da metamorfose dos seus companheiros por acção de drogas - tudo patranhas que ele impingiu aos parvos dos Feaces.

4. Em face de toda esta produção, não verberei por aí além os seus autores, porquanto verificava que tal era então habitual, mesmo entre os que faziam profissão de filósofos. Uma coisa, no entanto, me espantava neles: o facto de cuidarem que as mentiras que escreviam passariam despercebidas.

E foi assim que também eu, por vanglória, resolvi deixar à posteridade qualquer coisa do género, só para não ser o único a não beneficiar da faculdade de contar histórias fantásticas. E já que não tinha nada de verídico para narrar (na realidade, não me tinha sucedido nada digno de registo), virei-me para a mentira, mas uma mentira mais desculpável que a daqueles, porquanto numa coisa serei eu verdadeiro: ao confessar que minto. Desta forma, isto é, declarando que não digo nem uma ponta de verdade, creio ficar absolvido da acusação que porventura me façam. Escrevo, pois, sobre coisas que não testemunhei nem experimentei, e que náo soube da boca doutrem; mais ainda: que não existem em absoluto e que, de qualquer forma, não são susceptíveis de ocorrer. Portanto, não deve o leitor dar o mínimo crédito às minhas histórias.

5. Ora bem: um dia, tendo partido das Colunas de Hércules ${ }^{129}$, apontei ao oceano ocidental, navegando com vento favorável ${ }^{130}$. Causa e objectivo da viagem: a curiosidade intelectual, o desejo de experimentar novidades e a vontade de saber como é o fim do oceano e que espécie de homens habitam do lado de lá. Para

${ }^{129}$ Colunas de Hércules é o nome antigo do Estreito de Gibraltar.

130 «com vento favorável» ou, lit. ${ }^{\text {te }}$, «com vento de cauda». Recorde-se que a navegação à vela era muito difícil na Antiguidade... 
tanto, fiz uma provisão enorme de víveres, abasteci-me de água em quantidade suficiente e recrutei cinquenta companheiros que tinham o mesmo ideal que eu; além disso, provi-me duma assaz razoável quantidade de armas; consegui contratar por bom salário o melhor piloto e reforcei o navio - um veleiro - com vista a uma viagem prolongada e rude.

6. Navegávamos nós havia um dia e uma noite, com vento favorável, à vista de terra e vogando com velocidade moderada, e eis que, no dia seguinte, ao nascer do sol, começou a levantar-se vento; a ondulação ia aumentando, e pôs-se um tempo escuro, a ponto de já nem sequer nos ser possível ferrar a vela. Ao sabor do vento e entregues a ele, fomos fustigados pela tempestade durante setenta e nove dias; ao octogésimo, porém, descobriu subitamente o sol, e eis que avistámos, não longe dali, uma ilha montanhosa e arborizada, batida por uma ondulação marulhante, mas não impetuosa; de facto, o pior da tormenta já havia passado. Assim, atracámos e, uma vez desembarcados, e como pessoas saídas duma longa provação, deixámo-nos ficar muito tempo estendidos por terra. Finalmente, erguemo-nos e escolhemos trinta de nós para ficarem de guarda ao navio, enquanto os outros vinte subiriam comigo a explorar a ilha.

7. Ora, tendo nós avançado, através do bosque, coisa de três estádios ${ }^{131}$ de distância do mar, vimos uma coluna de bronze com uma inscrição gravada em caracteres gregos, mas já pouco distintos e muito gastos, que dizia: "A ESTAS PARAGENS APORTARAM HÉRACLES E DIONISO». Viam-se ainda, ali perto, numa rocha, duas pegadas: uma do tamanho de 1 pletro $^{132}$, e a outra mais pequena; esta, a menor, era - creio de Dioniso, e a outra era de Héracles.

Tendo-lhes prestado culto, prosseguimos. Ainda não tínhamos andado muito, quando deparámos com um rio, em cujo leito corria um vinho extremamente parecido com o de Quios. A corrente era caudalosa e profunda, de tal modo que, em certos lugares, poderia mesmo ser navegável. Assim, ao

131 c. 540 metros.

1321 pletro $=100$ pés $=$ c. 30 metros. Mesmo para medidas divinas, Luciano divertiu-se a exagerar o tamanho do pé de Héracles! Do pé de Dioniso, diz, modestamente, que era «mais pequena». 
vermos os sinais da viagem de Dioniso ${ }^{133}$, ainda mais crédito éramos levados a dar à inscrição da coluna.

Ora, tendo resolvido descobrir onde nascia o rio, fui subindo ao longo da margem, não encontrando qualquer nascente, mas sim muitas e enormes videiras, carregadas de cachos; junto à raiz de cada uma, escorria um fio de vinho transparente - fios esses donde se formava o rio. Também podíamos ver nele muitos peixes, de cor e gosto muito semelhantes a vinho. Então pescámos alguns e comemo-los, com o que ficámos embriagados. É certo que, tendo-os aberto, os achámos cheios de mosto. Mais tarde, tivemos a ideia de os misturar com outros peixes, os de água, a fim de destemperarmos a comida avinhada em excesso.

8. Foi então que, tendo passado o rio onde havia vau, descobrimos algo de muito espantoso que se passava com as videiras: da parte que saía da terra, o tronco propriamente era vigoroso e grosso, enquanto na parte de cima eram mulheres, com todas as partes completas das ancas para cima - tal qual entre nós se representa Dafne no momento em que Apolo se prepara para agarrá-la e ela se transforma em árvore ${ }^{134}$. Das pontas dos dedos nasciam-lhes ramos, que estavam carregados de cachos. Além disso, possuíam uma farta cabeleira de gavinhas, parras e cachos. Quando nos aproximámos, não paravam de nos cumprimentar e saudar (umas em língua lídia, outras em índico, a maioria em grego), e beijavam-nos na boca. Aquele que era beijado ficava imediatamente embriagado e cambaleante. Contudo, náo nos deixavam colher qualquer fruto, mas antes gemiam de dor e gritavam, se lhes arrancavam algum. Outras manifestavam mesmo desejos de se unirem a nós, e aconteceu que dois dos nossos companheiros, tendo-se chegado a elas, já não eram capazes de se libertar, pois ficaram presos pelas partes viris. E de facto, cresciam juntos e criavam raízes em comum, e já mesmo lhes nasciam ramos nas pontas dos dedos; ficavam entrelaçados mas gavinhas e, em pouco tempo, estavam eles próprios aptos a dar fruto.

9. Deixámo-los ali e pusemo-nos em fuga para o navio, onde contámos aos que haviam ficado todas as nossas aventuras, incluindo o casamento dos nossos companheiros com as videiras.

${ }^{133}$ Recorde-se que o vinho fora invenção de Dioniso, também chamado Baco.

${ }^{134}$ Luciano não precisava de especificar o nome da árvore (dáphnê "loureiro»), que era o mesmo que o da ninfa: Dáphnê. 
Em seguida, pegámos numas ânforas, que enchemos, tanto de água, como de vinho do rio, e acampámos perto dali, na praia.

Ao raiar do dia, fizemo-nos ao largo, com vento não muito forte. Por volta do meio-dia, e já sem avistarmos a ilha, eis que subitamente se formou um tufão, que fez o navio dar várias voltas e o elevou nos ares coisa de 300 estádios $^{135}$, sem o deixar cair no mar, mas antes, o vento, soprando sobre as velas, enfunava o pano e assim fazia vogar o navio suspenso no ar.

10. Tendo navegado no ar durante sete dias e outras tantas noites, ao oitavo avistámos no ar uma terra enorme, como que uma ilha, mas brilhante, esférica e completamente iluminada por uma luz muito forte. Aproximámo-nos, lançámos âncora e desembarcámos. Ao examinarmos a terra, descobrimos que era habitada e cultivada. Durante o dia, no entanto, nada avistámos dali, mas, quando chegou a noite, começaram a aparecer, por perto, muitas outras ilhas, umas maiores, outras mais pequenas, cor de fogo, bem como uma outra terra, por baixo de nós, com cidades, rios, mares, matas e montanhas, e que depreendemos tratar-se do planeta que habitamos.

11. Ora, tendo nós resolvido prosseguir um pouco mais adiante, fomos interceptados e detidos pelos (assim se chamam) Cavaleiros-Abutres ${ }^{136}$. Estes Cavaleiros-Abutres são homens montados em abutres, que utilizam tais aves como montada. E realmente, os abutres são enormes e, na sua maioria, tricéfalos. Por aqui se pode ter uma ideia do seu tamanho: têm cada pena mais comprida e mais grossa que o mastro dum grande navio de carga. Ora, a estes Cavaleiros-Abutres está confiada a missáo de sobrevoar o País e, em caso de encontrarem algum estrangeiro, conduzi-lo à presença do rei. E de facto, detiveram-nos e conduziram-nos a ele, o qual, ao ver-nos, e deduzindo pelo nosso modo de trajar, disse: «Sois então gregos, não é assim, estrangeiros?» E tendo nós respondido que sim, perguntou-nos: "Como é que conseguistes atravessar tamanha extensão de céu e chegar até aqui?» Então nós contámos-lhe tudo. $\mathrm{O}$ rei, por seu lado, contou-nos a sua própria história; de como, sendo

135 c. $53 \mathrm{Km}$ : é obra!

${ }^{136}$ Hipógypi, ou, na forma adaptada ao port., Hipogipos. Preferi, no entanto, traduzir este e outros nomes que se seguem, em consideração pelo leitor. 
também ele um terrestre, de nome Endímion, fora uma vez, durante o sono, arrebatado do nosso planeta e, tendo aportado àquela terra, se tornou rei dela; que essa terra - dizia - era a Lua, que nós vemos lá de baixo. Além disso, exortou-nos a que tivéssemos coragem e náo temêssemos qualquer perigo, pois teríamos tudo de que precisássemos.

12. «E caso - prosseguiu - me saia bem da guerra que agora travo contra os habitantes do Sol, passareis aqui a vida mais feliz que se possa imaginar.» Entáo nós perguntámos quem eram os seus inimigos e qual a causa das hostilidades.

"Foi o caso - disse - que Faetonte, o rei dos habitantes do Sol (na verdade aquele astro é habitado, tal como a Lua), já há muito tempo que nos faz guerra. Eis como as coisas começaram: uma vez, tendo eu convocado os mais pobres de entre os que viviam no meu reino, resolvi enviar uma colónia a Vénus, que era deserta e completamente desabitada. Então Faetonte, por inveja, impediu a expedição, interceptando-a a meio caminho, à frente dos Cavaleiros-Formigas ${ }^{137}$. Nessa ocasião, fomos derrotados (realmente, no tocante a armamento náo éramos adversários à altura), pelo que tivemos de recuar. Agora, porém, pretendo reabrir as hostilidades e enviar a expediçáo colonizadora. Se vós assim o entenderdes, juntai-vos a mim nesta campanha, que eu vos fornecerei abutres, dos reais, um a cada um de vós, bem como o demais armamento. Amanhã pôr-nos-emos a caminho." "Assim seja-disse eu -, já que é do vosso agrado."

13. Nesse dia ficámos hospedados no palácio do rei, mas, logo ao raiar da aurora, levantámo-nos e ocupámos os nossos postos. De facto, as sentinelas assinalavam a chegada iminente dos inimigos.

O efectivo do nosso exército ascendia a 100.000 homens, sem contar com os carregadores, pessoal de engenharia, soldados de infantaria e aliados estrangeiros. Deste efectivo, 80.000 eram Cavaleiros-Abutres, e 20.000 Hortaliças-Voadoras ${ }^{138}$. Trata-se dum enorme pássaro que, em vez de penas, tem todo o corpo coberto de hortaliça e asas extremamente semelhantes a folhas de alface. Além destas aves, alinhavam também os Lançadores-de-Bagos-de-Milho ${ }^{139}$ e os Combatentes-de-Alho ${ }^{140}$. Vieram

${ }^{137}$ Hippomýrmêkes, Hipomirmeces... que o leitor comum não entenderia...

${ }^{138}$ Lakhanópteroi, Lacanópteros.

139 Kenkhrobóloi, Cencróbolos.

140 Skorodomákhoi, Escorodómacos. 
também em auxílio do rei os aliados da Ursa Maior: 30.000 Lançadores-de-Pulgas $^{141}$ e 50.000 Corredores-de-Vento ${ }^{142}$. Os Lançadores-de-Pulgas vinham montados em enormes pulgas, donde lhes vem a designação. $\mathrm{O}$ tamanho das pulgas era qualquer coisa como doze elefantes. Quanto aos Corredores-de-Vento, são soldados de infantaria, que se movem no espaço sem asas. O seu modo de locomoçáo é como segue: amarram ao corpo uma túnica comprida, que fazem enfunar ao vento, à maneira de vela, e desse modo se deslocam, como se fossem barcos. $\mathrm{Na}$ sua maioria são peltastas ${ }^{143}$. Dizia-se também que das estrelas do céu da Capadócia viriam 70.000 Pardais-de-Montado ${ }^{144}$ e 5.000 Cavaleiros-Grous ${ }^{145}$. Estes, porém, não cheguei a vê-los: na verdade, não vieram, pelo que não me atrevi a descrever-lhes o tipo físico. Efectivamente, diziam-se a respeito deles coisas mirabolantes e incríveis ${ }^{146}$.

14. Estas eram as forças de Endímion. Quanto ao equipamento, era igual para todos: elmos feitos de favas (realmente, naquela terra as favas são enormes e resistentes); couraças em escama, todas feitas de tremoços (de facto, cosem umas às outras as cascas de tremoços, e assim fabricam as couraças; naquela terra, a casca do tremoço torna-se mais dura que cornos); quanto a escudos e espadas, sáo como os gregos.

15. Na altura devida, eis como as forças se dispuseram: a ala direita, ocupavam-na os Cavaleiros-Abutres e o rei, rodeado de soldados de élite, entre os quais estávamos nós. Na ala esquerda estavam os Hortaliças-Voadoras. E ao centro ficaram os aliados, na forma que cada um entendeu. No que toca à infantaria, eram à volta de $60.000 .000^{147}$ de combatentes, assim ordenados: naquelas paragens, as aranhas são abundantes e tornam-se enormes, todas muito maiores que as das ilhas Cíclades. Foi-lhes confiada a missão de tecer uma teia no espaço compreendido entre a Lua e Vénus.. Rapidamente concluída a tarefa, ficou uma planície,

${ }^{141}$ Psyllotoxótai, Psilotóxotas.

142 Anemodrómoi, Anemódromos.

143 Soldados de infantaria ligeira.

144 Strouthobálanoi, Estrutobálanos.

145 Hippogéranoi, Hipogéranos.

146 Não deixam de ser curiosos o "pudor» e a "contenção» de Luciano.

${ }^{147}$ Mesmo compreendendo a fantasia à solta do Autor, convém confirmar que este diz mesmo "seis mil vezes dez mil», ou seja, "sessenta milhóes». 
sobre a qual alinhou a infantaria, comandada por Nicteriáo ${ }^{148}$, filho de Eudianacte, e mais dois chefes.

16. Do lado do inimigo, a ala esquerda era ocupada pelos Cavaleiros-Formigas, entre os quais estava Faetonte. Estes animais, muito avantajados, têm asas e são semelhantes às nossas formigas, excepto no tamanho. De facto, a maior delas chegava a atingir 2 pletros $^{149}$. E não eram só os que as montavam que combatiam, mas também elas próprias, de preferência com os cornos. Dizia-se que o seu número ascendia a cerca de 50.000. À sua direita alinhavam os Mosquitos-Aéreos ${ }^{150}$, em número igualmente à volta de 50.000, e que eram, todos eles, Arqueiros, montados em enormes mosquitos. A seu lado estavam os Bailarinos-do-Espaço ${ }^{151}$, que eram soldados de infantaria ligeira, e também muito aguerridos: de facto, armados de fundas, lançavam de muito longe rábanos descomunais, e quem fosse atingido não resistia um momento sequer, mas morria, e a ferida começava a exalar um mau cheiro especial. Dizia-se que besuntavam os projécteis com veneno de malva. Ao lado destes alinharam os Talos-Cogumelos ${ }^{152}$, que eram hoplitas ${ }^{153} \mathrm{e}$ combatiam corpo a corpo. Eram em número de 10.000. Foram denominados Talos-Cogumelos pelo facto de se servirem de cogumelos como escudos e usarem como lanças os talos de espargos. Perto deles encontravam-se os Cáes-Bolotas ${ }^{154}$, que os habitantes de Sírio enviaram ao rei, em número de 5.000. Eram homens com cabeça de cão e combatiam montados em bolotas aladas. Dizia-se que faltavam ainda, entre os aliados, uns que o rei mandara vir da Galáxia ${ }^{155}$, os quais eram lançadores de funda, e ainda os Centauros-das-Nuvens ${ }^{156}$. Estes últimos,

${ }^{148}$ Nicterião, referência à noite: "Nocturno»; Eudianacte, lit. ${ }^{\text {te }}$ "Senhor da Serenidade»». Personagens completamente imaginadas pelo A.

149 c. 60 metros.

150 Aerokônòpes, Aeroconopes.

151 Aerokórdakes, Aerocordaces. Outras ediçōes têm Aerokórakes, "Corvos-do-Espaço» (que adaptada segundo as regras, daria Aerocóraces), ou Aerokárdakes, "Mercenários-do-Espaço»(que daria a forma aportuguesada Aerocárdaces.

152 Kaulomýkêtes, Caulomicetes.

153 Soldados de infantaria pesada.

${ }^{154}$ Kynobálanoi, Cinobálanos.

155 Ou Via Láctea.

156 Nephelokéntauroi, Nefelocentauros. 
porém, chegaram quando a batalha já estava decidida, e mais valera não terem vindo ${ }^{157}$. Quanto aos Lançadores-de-Funda, nem sequer se apresentaram, pelo que, segundo se diz, mais tarde Faetonte, irritado com eles, pôs o seu país a ferro e fogo. Tais eram as forças com que se apresentou Faetonte.

17. Erguidas as bandeiras, de parte a parte os burros começaram a zurrar (pois servem-se deles como corneteiros). Então passaram ao ataque e deram início à batalha.

A ala esquerda dos Heliotas ${ }^{158}$ não tardou a pôr-se em fuga, sem sequer esperar pelo embate com os Cavaleiros-Abutres; e nós, pela nossa parte, perseguíamo-los e matávamo-los. No entanto, a ala direita deles dominava, irrompendo pela nossa ala esquerda, com os Mosquitos-Aéreos a virem lá de trás e a avançarem até à nossa infantaria. Mesmo assim, e apesar daquele auxílio, deram meia volta e puseram-se em fuga, tanto mais que se tinham apercebido da derrota da sua própria ala esquerda. Na debandada geral, muitos eram apanhados vivos, mas muitos outros eram liquidados, de forma que o sangue corria em abundância, uma parte sobre as nuvens (a ponto de estas ficarem tingidas duma cor vermelha, tal como, entre nós, nos aparecem ao pôr do sol), e outra parte espalhando-se sobre a Terra, de tal modo que fiquei a pensar se não teria sido por causa dum facto deste género, ocorrido antigamente, que Homero supôs ser Zeus a chover sangue pela morte de Sarpédon.

18. Ora, regressando nós da nossa peregrinaçáo, erguemos dois monumentos triunfais, um na teia de aranha, em comemoração da batalha naval, e outro nas nuvens, em comemoração da batalha espacial. Mal tínhamos terminado, eis que as nossas sentinelas assinalam a chegada dos Centauros-das-Nuvens, os quais deviam ter chegado antes da batalha para reforçarem Faetonte. A verdade é que aí vinham eles avançando e constituindo um espectáculo deveras extraordinário, meio cavalos alados e meio homens. A estatura dos homens era qualquer coisa como a do colosso de Rodes da cintura para cima; e a dos cavalos era como a dum grande navio mercante. Quanto ao seu número, não o registo, para que năo pareça um tanto

157 ... para mal dos nossos pecados: v. $\$ 18$.

${ }^{158}$ Heliotas, «habitantes do Sol»; como Selenitas, "habitantes da Lua». 
incrível ${ }^{159}$, tão elevado ele era. Comandava-os o arqueiro do Zodíaco. Ao constatarem que os seus amigos estavam vencidos, enviaram uma delegação a Faetonte, para que este atacasse de novo. Entretanto, porém, póem-se em ordem de batalha e caem sobre os perturbados Selenitas, os quais, em desordem, se ocupavam de perseguiçóes e pilhagens. Póem-nos a todos em debandada, perseguindo o nosso próprio rei até à cidade e matando-lhe quase todos os pássaros. Arrancaram os monumentos triunfais, percorreram toda a planície tecida pelas aranhas, e aprisionaram-me a mim e a dois dos meus companheiros. Nessa altura, já Faetonte havia chegado, e novos monumentos triunfais foram erguidos. Nesse mesmo dia, com as máos ligadas atrás das costas com teias de aranha, fomos conduzidos ao Sol.

19. O inimigo decidiu náo atacar a nossa cidade, mas sim regressar e construir uma muralha a meio do espaço, de forma que os raios vindos do Sol não atingissem a Lua. Era uma muralha dupla, feita de nuvens, de modo que aconteceu um autêntico eclipse de lua, a qual ficou toda envolvida em noite espessa. Pressionado por tal facto, Endímion enviou uma embaixada a solicitar que deitassem abaixo a construção e não os deixassem a viver na escuridão; prometia pagar um tributo, ser aliado deles e nunca mais lhes fazer guerra, além de espontaneamente lhes entregar reféns.

Reunida por duas vezes a Assembleia, na primeira Faetonte e os seus ministros não acalmaram a sua cólera, mas na segunda alteraram a posição, e a paz foi firmada com o seguinte articulado:

20. "Nos termos seguintes, os Heliotas e seus aliados celebraram um tratado com os Selenitas e seus aliados:

- Os Heliotas destroem a muralha e nunca mais atacarão a Lua; além disso, restituem os prisioneiros, cada um pela quantia combinada; - Quanto aos Selenitas, concedem a autonomia aos outros astros e não voltarão as suas armas contra os Heliotas, mas antes se aliarão em caso de serem atacados por terceiros;

- O rei dos Selenitas pagará ao rei dos Heliotas, a título de tributo, $e$ anualmente, 10.000 ânforas de orvalho, e enviar-lhe-á 10.000 reféns dentre o seu povo;

- Quanto à colónia a enviar a Vénus, fundá-la-ão em comum, podendo nela participar qualquer outro povo que assim o entender;

${ }^{159}$ Mais uma vez, Luciano finge certo pudor e alguma contenção... 
- Este tratado será gravado numa coluna de âmbar, a erguer no espaço, na fronteira entre os dois Países;

Prestaram juramento:

Pelos Heliotas: Pirónides, Teritas e Flógio;

Pelos Selenitas: Níctor, Ménio e Polilampes ${ }^{160}$."

\section{Assim se restabeleceu a paz.}

Imediatamente a muralha foi destruída e devolveram os prisioneiros, ou seja, nós, Logo que chegámos à Lua, vieram receber-nos e abraçar-nos, com lágrimas nos olhos, os nossos camaradas e o próprio Endímion, o qual pediu que ficássemos junto dele e participássemos na fundação da colónia, prometendo dar-nos em casamento o seu próprio filho (pois entre eles não há mulheres). Eu, porém, não me deixei convencer, tendo-lhe antes solicitado que me deixasse ir lá abaixo, para o mar.

Ao compreender que era impossível convencer-me, deixou-nos partir, não sem que antes nos tivesse como hóspedes durante sete dias.

22. Agora proponho-me contar o que, neste período que passei na Lua, me pareceu novo e bizarro.

Antes de mais, o facto de eles não nascerem de mulheres, mas de seres machos. Na verdade, casam homens com homens, e não conhecem absolutamente nenhum nome de mulher. Até aos vinte e cinco anos, cada um casa fazendo de mulher, e dessa idade em diante faz de marido. E engravidam, não pelo ventre, mas pela barriga das pernas. De facto, assim que o feto é concebido, a perna engrossa; algum tempo mais tarde, praticam uma incisão e retiram o feto, mas morto, e que eles ressuscitam expondo-o ao ar com a boca aberta. Creio mesmo que foi desse facto que ocorreu aos gregos esta designaçáo de «barriga da perna», porque entre eles são as pernas que engravidam, e não os ventres.

Mas vou contar uma outra coisa mais extraordinária que esta. Existe lá uma espécie de homens, chamados Dendritas ${ }^{161}$, que são gerados da forma seguinte: cortam o testículo direito dum homem, plantam-no na terra, e dele cresce uma árvore enorme, de carne, tal qual um pénis. Até tem ramos e folhas.

${ }^{160}$ Os nomes dos Heliotas fazem referência a "fogo», "estio» e «ardor"; os dos Selenitas aludem a "noite», "mês» e "brilho».

${ }^{161}$ Dendritas, «seres gerados de árvores» (déndron «árvore»). 
Quanto aos frutos, são bolotas do tamanho de um côvado ${ }^{162}$. Logo que estas amadurecem, colhem-nas e retiram-lhes homens de dentro. Usam órgãos sexuais postiços, uns de marfim, e outros (os dos pobres) de madeira, e é com tais órgãos que criam cio e se unem aos seus pares.

23. Quando o homem envelhece, não morre, mas antes dissolve-se como fumo e transforma-se em gás. Todos têm a mesma alimentaçáo: de facto, fazem uma fogueira e assam rás sobre as brasas (existem lá rãs em grande quantidade, voando no ar). Enquanto os animais vão assando, juntam-se à volta do lume como se fosse à volta duma mesa, inalam o fumo que se desprende e saciam-se dele. É com esse alimento que se sustentam.

Quanto à sua bebida, é o ar espremido para dentro duma taça, produzindo um líquido semelhante ao orvalho. Também não urinam, nem evacuam, pois não têm um orifício como nós, de forma que os adolescentes náo têm relaçóes pelo ânus, mas sim na curva interior do joelho, acima da barriga da perna, que é ali que têm um orifício.

Entre eles, é considerado belo quem é calvo ou desprovido completamente de cabelos, ao passo que detestam os cabeludos, os komêtai ${ }^{163}$. Nos cometas, pelo contrário, consideram belos os cabeludos, coisa que nos foi contada por pessoas que tinham vindo de lá. Além disso, os Selenitas têm barba, a qual cresce um pouco acima dos joelhos, mas náo têm unhas dos pés, já que todos são monodáctilos. Acima das nádegas nasce-lhes uma grande couve, como se fosse uma cauda, a qual está sempre viçosa e não se quebra se a pessoa cai de costas.

24. Do nariz segregam um mel muito azedo. E quer trabalhem, quer façam exercícios, suam leite por todo o corpo, a ponto de com ele fazerem queijos, desde que lhe juntem um pouco de mel. Por outro lado, fazem, a partir de alhos, um azeite extremamente gordo e perfumado como mirra. Videiras também têm muitas, mas dáo água: de facto, os bagos de uva sáo como granizo, de modo que, a meu ver, quando se levanta

162 c. $45 \mathrm{~cm}$.

163 Há aqui um jogo de palavras entre komêtai (adj.), "cabeludos», "providos de cabeleira", e komêtai (adj. substantivado), "(astro) com cabeleira", donde "cometa». 
vento, este sacode as videiras, arranca os cachos, e é então que cai sobre nós o granizo.

O estômago deles é como um saco, onde guardam tudo de que necessitam, pois este ora está aberto, ora fechado, e nele não se vêem nem intestinos nem fígado, mas apenas um interior todo ele peludo e eriçado, de forma que os recém-nascidos, quando o frio é muito, se aconchegam aí.

25. Quanto ao vestuário, o dos ricos é de metal macio, e o dos pobres é de malha de bronze (na verdade, aquele país é muito rico em bronze, que eles trabalham mergulhando-o na água, como se faz à lã). No que respeita aos olhos, hesito em dizer como são, não vá alguém cuidar que minto, tal é o incrível da história ${ }^{164}$. Apesar de tudo, porém, vou contar: têm olhos desenroscáveis, de modo que qualquer um pode tirar os seus e guardá-los, até voltar a precisar de ver; então coloca-os para ver. Muitos, tendo perdido os seus próprios olhos, vêem com olhos que pedem emprestados a outros. Há até quem tenha muitos de reserva - os ricos. Quanto às orelhas, são folhas de plátano, excepto as daqueles que nasceram de bolotas, os quais possuem. e só eles, orelhas de madeira.

26. Vi ainda uma outra maravilha no palácio real: existe lá um enorme espelho numa cisterna náo muito profunda. Descendo à cisterna, ouve-se tudo o que se diz entre nós, na Terra; e olhando pelo espelho, vêem-se todas as nossas cidades e todos os povos, como se estivéssemos lá. Então, eu próprio vi os meus familiares e toda a minha pátria; se eles me viram a mim, não posso afirmar com segurança. E quem não acreditar que isto é assim, se alguma vez lá for, ficará a saber que é verdade o que eu conto.

27. A certa altura, depois de saudar o rei e a sua corte, embarcámos e fizemo-nos ao largo. Endímion ofereceu-nos presentes: duas túnicas de cristal, cinco de bronze e uma armadura de tremoços - tudo coisas que perdi dentro da baleia ${ }^{165}$. Além disso, mandou vir mil Cavaleiros-Abutres para nos escoltarem até à distância de 500 estádios $^{166}$.

\footnotetext{
${ }^{164}$ Mais uma vez, Luciano finge-se "comedido».

165 O A. antecipa um episódio passado na barriga duma baleia.

166 c. $90 \mathrm{~km}$.
} 
28. No nosso caminho, passámos ao largo doutros países e chegámos mesmo a ancorar em Vénus, que estava justamente a ser colonizada.

Aí desembarcámos e abastecemo-nos de água. Seguidamente, deixando o Sol à nossa esquerda, apontámos em direcção ao Zodíaco, mas apenas navegámos junto das suas margens, De facto, não chegámos a desembarcar, embora muitos dos meus companheiros o desejassem... só que o vento não o permitia. Verificámos, no entanto, que o país era verdejante, fértil, rico de água e cheio de tudo o que é bom. Foi então que os Centauros-das-Nuvens, mercenários ao serviço de Faetonte, ao verem-nos, se lançaram em voo sobre o navio; todavia, uma vez informados de que nós constávamos do tratado, afastaram-se. Nessa altura, já os Cavaleiros-Abutres haviam partido.

29. Navegando toda a noite seguinte e todo o dia, ao cair da noite chegámos à chamada Cidade-das-Lanternas ${ }^{167}$, agora já prosseguindo a nossa viagem em sentido descendente. Esta cidade fica situada no espaço que medeia entre as Plêiades e as Híades, mas muito abaixo do Zodíaco. Desembarcámos, sem no entanto encontrarmos qualquer pessoa, mas sim muitas lanternas que se moviam dum lado para outro e passeavam na praça e na zona do porto - umas pequenas e, por assim dizer, pobres, e outras, poucas (as dos grandes e poderosos), muito brilhantes e bem visíveis. Cada uma possuía a sua residência particular e o seu próprio armazém de artigos de iluminação; tinham nomes, como as pessoas, e também as ouvimos pronunciar palavras; não nos faziam mal, e até nos convidavam para suas casas. Nós, porém, tivemos receio, de modo que nenhum de nós se atreveu a cear ou adormecer [lá].

No centro da cidade ergue-se o tribunal, onde o respectivo magistrado permanece toda a noite, chamando cada uma pelo seu nome; e toda aquela que não responde à chamada é condenada à morte por deserção. A morte consiste em serem apagadas. Assistimos presencialmente aos julgamentos e ouvimos as lanternas defenderem-se e explicarem os motivos pelos quais se haviam atrasado. Lá reconheci a minha lanterna, à qual me dirigi, pedindo-lhe informaçôes sobre como iam as coisas lá por casa. E ela contou-me tudo.

${ }^{167}$ Lykhnópolis, Licnópolis. 
Naquela noite ficámos ali mesmo, mas na seguinte levantámos ferro e rumámos já para as bandas das nuvens, onde avistámos a Cuculândia-Entre-Nuvens ${ }^{168}$, que admirámos, sem, no entanto, termos desembarcado nela, que não o permitia o vento. Dizia-se que quem governava lá era Corono, filho de Cotifiāo $^{169}$. Então lembrei-me do poeta Aristófanes, homem sabedor e amigo da verdade, mas cujos escritos tão injustamente foram postos em dúvida ${ }^{170}$. Passados três dias, já avistávamos claramente o oceano, mas de terra, nada, a não ser, é claro, as do espaço, que se apresentavam cor de fogo e com um brilho irradiante. Ao quarto dia, por volta do meio-dia, levantou-se uma brisa suave, que, mudando de rumo, nos impelia para baixo, em direcção ao mar.

30. Mal tocámos na água, sentimos um prazer extraordinário, uma alegria intensa, e então fizemos a festa possível naquelas circunstâncias: saltámos do barco e começámos a nadar, pois o tempo estava bom e o mar calmo.

Ora, muitas vezes a mudança para melhor parece ser o começo de males maiores. E realmente, tendo nós navegado apenas dois dias com tempo bonançoso, eis que, ao despontar do terceiro dia, mesmo ao nascer do sol, subitamente vemos, entre muitos e variados animais marinhos, uma baleia maior que todos eles, com um comprimento de cerca de 1.500 estádios $^{171}$, e que se dirigia para nós, de boca aberta, agitando violentamente o mar, fazendo espuma à sua volta e mostrando uns dentes mais compridos que os falos da nossa terra, e todos aguçados como estacas e brancos como marfim. Então nós dissemos o último adeus uns aos outros, abraçámo-nos e ficámos à espera. A baleia, que entretanto chegara, sorveu-nos e engoliu-nos juntamente com o navio. Não chegou, no entanto, a trincar-nos com os dentes, pois o navio escapou-se para o interior através do espaço entre eles.

${ }^{168}$ Nephelokokkygía, Nefelococígia, "Cidade-dos-Cucos-Entre-Nuvens», é a célebre cidade inventada por Aristófanes (Aves).

169 Kórônos, Corono, parece significar «codorniz» (mas a palavra, em grego, é masculina); Kottyphiôn Cotifião significa «melro».

${ }^{170} \mathrm{O}$ leitor perceberá a subtileza da prova de que Nefelococígia existia mesmo: já não é só a palavra de Aristófanes, mas o testemunho ocular do viajante Luciano.

${ }^{171}$ c. $270 \mathrm{~km}$. É obra! 
31. Uma vez lá dentro, a princípio estava escuro e não víamos nada, mas depois, quando ela voltou a abrir a boca, vimos uma grande caverna, completamente plana e muito alta, com capacidade para uma cidade de cerca de 10.000 habitantes. No seu interior, jaziam peixes grandes e pequenos, e muitos outros animais, tudo misturado, bem como mastros de navios, âncoras, ossadas humanas e mercadorias. Mais ou menos a meio, havia uma extensão de terra, com colinas, e formada, a meu ver, do lodo que o monstro engolira. Nessa terra nascera uma mata de árvores de toda a espécie; também cresciam hortaliças, tudo com o aspecto de ser cultivado. O perímetro da terra era de 240 estádios $^{172}$. Viam-se também aves marinhas, tais como gaivotas e alcíones, que nidificavam nas árvores.

32. Então, durante longo tempo não fazíamos senão chorar, mas, por fim, sacudi os meus companheiros e, todos juntos, escorámos o navio; depois, esfregando pauzinhos, fizemos uma fogueira e preparámos uma ceia com o que havia à mão. Havia por ali carne em abundância e de toda a espécie, quer dizer, de peixes; e ainda tínhamos água da que trouxéramos de Vénus. No dia seguinte, e já levantados, se acontecia a baleia abrir a boca, víamos ora montanhas, ora apenas céu, e muitas vezes ilhas: realmente, apercebíamo-nos de que o animal se movia velozmente por toda a extensão do mar. Uma vez habituados a este modo vida, escolhi sete dos meus companheiros e dirigi-me para a mata, disposto a explorar aquilo. Foi assim que, náo tendo bem percorrido 5 estádios ${ }^{173}$, dei com um templo - de Posídon, a julgar pela inscriçáo. Pouco depois, vimos muitos túmulos encimados por colunas, e, ali perto, uma nascente de água límpida; mais ainda: ouvimos o ladrar dum cáo, depois apareceu ao longe uma coluna de fumo e avistámos mesmo uma quinta.

33. Caminhando a passo apressado, demos com um velho e um jovem, que afanosamente cultivavam uma horta e a regavam com água da nascente. Ao mesmo tempo contentes e receosos, estacámos. E eles, por seu lado, aparentemente sentindo o mesmo que nós, também ficaram mudos e quedos. Um pouco depois, porém, o velho falou: "Quem sois vós, estrangeiros? Sereis porventura divindades marinhas, ou simplesmente homens desafortunados,

\footnotetext{
172 c. $43 \mathrm{~km}$.

173 c. $900 \mathrm{~m}$.
} 
tal como nós? Sim, que nós somos seres humanos, criados na Terra, mas que agora nos tornámos marinhos, navegando juntamente com o monstro que nos tem dentro dele, sem sabermos ao certo o que se passa connosco; de facto, tudo indica que estamos mortos, e, no entanto, cremos estar vivos.» A estas palavras respondi: "Também nós, avozinho, somos seres humanos, acabados de chegar, ainda ontem engolidos com o nosso próprio barco. E agora pusemo-nos a caminho, na intenção de investigar como são as coisas aqui na mata, a qual nos pareceu grande e espessa. Foi com certeza alguma divindade que nos trouxe à tua presença, a fim de ficarmos a saber que náo somos os únicos prisioneiros dentro deste monstro. Mas conta-nos da tua sorte: quem eras e como vieste aqui parar."

Ele, porém, a princípio não queria falar nem perguntar-nos nada, sem que antes nos oferecesse os dons da hospitalidade ${ }^{174}$ possíveis naquelas circunstâncias, pelo que nos levou com ele e nos conduziu a sua casa, que ele mesmo havia construído com todos os pertences, como camas de folhas, enfim, tudo o mais que era preciso. Aí, ofereceu-nos legumes, frutos secos e peixe, tudo regado com vinho. E só quando já estávamos bem saciados nos interrogou sobre o que nos havia sucedido. Entáo eu narrei-lhe tudo de enfiada: a tempestade, a aventura na ilha, a navegação no espaço, a guerra e tudo o resto, até à nossa descida na barriga da baleia.

34. E foi então que ele, mui maravilhado, começou a expor, por seu lado, as suas aventuras:

«Estrangeiros, eu sou natural de Chipre. Tendo partido da minha pátria para comerciar, e levando comigo um filho, que aqui vedes, bem como muitos criados, navegava rumo à Itália, transportando carga vária num navio mercante, que talvez vós tenhais visto, todo desconjuntado, na boca da baleia. Ora, até por alturas da Sicília, a viagem decorria bem. A partir dai, porém, fomos apanhados por um vento forte, e ao fim de três dias fomos arrastados para o oceano, onde encontrámos a baleia, que nos engoliu a todos, tendo os outros morrido e salvando-nos apenas nós dois. Sepultámos os nossos companheiros, construimos um templo dedicado a Posidon, e agora levamos este género de vida, cultivando legumes e alimentando-nos de peixe e de frutos. A mata, como vedes, é grande, e até tem muitas videiras, que dão um vinho extremamente agradável. Também vistes, certamente, a nascente de água belissima e

${ }^{174}$ As regras da hospitalidade costumavam ser rigorosamente (melhor: religiosamente) observadas, como é o caso; v. o seguimento. 
muito fresca. Com as folhas fazemos a nossa cama e acendemos fogueiras quantas queremos; também caçamos pássaros que voam até aqui, e pescamos peixes vivos a saltar, bastando ir até às guelras do monstro, onde também tomamos banho sempre que nos apetece. Além disso, náo muito longe daqui há um lago de água salgada, com um perimetro de 20 estádios $^{175}$, e que possui peixes de toda a espécie; nadamos nas suas águas e navegamos num pequeno barco, que eu mesmo construi. Desde que fomos engolidos, já lá vão vinte e sete anos.»

35. "Tudo, a bem dizer, podemos suportar, menos os vizinhos e outros habitantes, que são muito difíceis de aturar, insociáveis e selvagens." "Quer dizer - exclamei - que há outras pessoas dentro da baleia?" "Sim-respondeu - há muitas, mas não são acolhedoras e, além disso, têm formas bizarras; de facto, na zona ocidental da mata e na parte de trás vivem os Salmoiros ${ }^{176}$, uma raça com olhos de enguia e cabeça de caranguejo, muito aguerrida, violenta e canibal. Do outro lado, para as bandas da direita do muro, há os Tritóes-Bodes ${ }^{177}$, que têm figura de homem da cintura para cima, e de bode da cintura para baixo, os quais são na verdade menos injustos que os outros. Quanto à parte esquerda, é ocupada pelos Mãos-de-Caranguejo ${ }^{178}$ e pelos Cabeças-de-Atum ${ }^{179}$, os quais têm um tratado de aliança e amizade mútuas. A zona interior ocupam-na os Caudas-Rijas ${ }^{180}$ e os Pés-Espalmados ${ }^{181}$, raça aguerrida e veloz. Quanto à região oriental, para os lados da boca do monstro, na sua maior parte é deserta e inundada pelo mar. Apesar disso, porém, é esta que eu habito, mediante um tributo de 500 ostras que pago anualmente aos Pés-Espalmados.»

36. "Tal é esta terra. A vós compete imaginar a forma de podermos lutar com tais povos e sobreviver."

"E quantos são eles ao todo? - perguntei eu» "Mais de mil-respondeu». "E que género de armas possuem?" "Nenhuma - disse - a não ser espinhas de peixe." "Nesse caso - retorqui - o melhor seria nós irmo-nos a eles e combatê-los, uma vez que eles estão desarmados e nós armados; se os vencermos, viveremos em paz o resto da vida."

175 c. $3,5 \mathrm{~km}$.

176 Tarikhánes, Taricanes, de tárikhos «salmoura», "salga».

177 Tritônoméndêtes, Tritonomendetes.

${ }^{178}$ Karkinókheires, Carcinoquires.

179 Thynnoképhaloi, Tinocéfalos.

180 Pagouridai, Pagúridas.

${ }^{181}$ Psêttópodes, Psetópodes, «que têm os pés espalmados como uma solha». 
O velho aprovou. Então regressámos ao navio e preparámo-nos. Quanto ao pretexto para a guerra, vinha mesmo a calhar que fosse a recusa de pagamento do tributo, cujo prazo era chegado. E, de facto, eis que nesse momento nos vinham exigir a prestação. Mas o velho respondeu desdenhosamente aos mensageiros e escorraçou-os. Irritados com Cíntaro (tal era o seu nome), os Pés-Espalmados e os Caudas-Rijas foram os primeiros a avançar, com grande alarido.

37. Nós, porém, prevendo o ataque, tomámos as armas e ficámos à espera, tendo colocado na primeira linha um pelotão de 25 homens, a quem tinha sido confiada a missão de ficarem emboscados e, assim que vissem que os inimigos já haviam passado por eles, lhes caíssem em cima. E assim fizeram: atacando-os por detrás, iam-lhes desferindo golpes, enquanto nós, também em número de 25 (contando com Cíntaro e o filho, que combatiam a nosso lado), lhes saíamos ao caminho e entrámos na refrega com alma e coração. Por fim, conseguimos pô-los em fuga, perseguindo-os até ao seu reduto. Do lado do inimigo morreram cento e setenta, e do nosso lado apenas um, aliás o piloto, com o peito trespassado por uma espinha de salmonete.

38. Aquele dia e mais uma noite, acampámos no campo de batalha. Espetámos no chão uma espinha dorsal de golfinho, e assim erguemos um monumento triunfal. No dia seguinte, porém, apareceram os outros, que tinham sabido do caso. Os Salmoiros ${ }^{182}$, comandados por Pélamo, ocupavam a ala direita; os Cabeças-de-Atum ${ }^{183}$ a ala esquerda, e os Mãos-de-Caranguejo ${ }^{184}$ o centro. Quanto aos Tritóes-Bodes ${ }^{185}$, mantinham-se quietos, preferindo não se aliar a nenhuma das partes. Então nós, saindo-lhes ao caminho junto do templo de Posídon, entrámos em luta corpo a corpo, com tâo grande algazarra, que o interior da baleia ecoava como o interior das cavernas. Mal armados como eles estavam, pusemo-los em fuga, perseguindo-os pela mata dentro, e, enfim, apoderámo-nos da terra.

182 Tarikhánes, Taricanes.

183 Thynnoképhaloi, Tinocéfalos.

${ }^{184}$ Karkinókheires, Carcinoquires.

185 Tritônoméndêtes, Tritonomendetes. 
39. Não passou muito tempo que não mandassem mensageiros para tratar de recolher os mortos e discutir os termos dum tratado de amizade. Nós, porém, entendemos que não era de negociar tréguas, e, no dia seguinte, voltando ao ataque, demos cabo deles todos, com excepçáo dos Tritôes-Bodes, os quais, no entanto, ao verem o que tinha sucedido aos outros, se escaparam pelas guelras ${ }^{186}$ da baleia e se atiraram ao mar. Então nós percorremos a terra, já limpa de inimigos, e habitámo-la toda em paz, ocupando a maior parte do tempo a fazer exercício físico e a caçar, cultivando a vinha e colhendo os frutos das árvores - enfim, assemelhávamo-nos perfeitamente a gente próspera e livre, mas, é claro, encerrada numa enorme prisão.

Durante um ano e oito meses levámos este modo de vida.

40. Ora, no quinto dia do nono mês, por volta da segunda abertura de boca (de facto, a baleia fazia isso de hora a hora, de forma que, pelas aberturas de boca, ficávamos a saber as horas), por volta, como ia dizendo, da segunda abertura, eis que subitamente começou a fazer-se ouvir uma grande algazarra e um tumulto, acompanhados como que de vozes de comando e pancadas de remo. Perturbados, trepámos até junto da boca do monstro e, colocando-nos no espaço entre os dentes, contemplámos o espectáculo mais estranho que até aí eu tinha visto: uns homens enormes, do tamanho de cerca de meio estádio ${ }^{187}$, navegando sobre grandes ilhas como em trirremes. E muito embora saiba que o que vou contar tem foros de incrível ${ }^{188}$, mesmo assim atrevo-me a dizer: as ilhas eram compridas, mas não muito elevadas, e cada uma delas tinha um perímetro de cerca de 100 estádios $^{189}$. Em cada ilha estavam embarcados à volta de 120 desses homens, uma parte dos quais, sentados quer a bombordo, quer a estibordo, e em fila, remavam com enormes ciprestes que conservavam as suas pernadas e a copa a servirem de remos. Atrás, por assim dizer à popa, e numa colina elevada, estava o piloto, o qual manejava um timáo de bronze com qualquer coisa como 5 estádios ${ }^{190}$ de comprimento. À proa, lutavam cerca de

${ }^{186}$ Nitidamente, os Antigos conheciam muito mal as baleias, confundindo-as com peixes.

187 c. $90 \mathrm{~m}$.

${ }^{188}$ Como se outras descriçôes não tivessem, também, foros de incrível!...

${ }^{189}$ c. $18 \mathrm{~km}$.

${ }^{190}$ c. $900 \mathrm{~m}$. 
quarenta guerreiros, em tudo semelhantes a homens, excepto na cabeleira, a qual era fogo e ardia, de forma que não necessitavam de elmos. No lugar de velas, o vento batia no arvoredo, que cada ilha tinha em abundância, e assim enfunava a mata e impelia a ilha para onde o piloto pretendesse. Assim, e também à força de remos, as ilhas moviam-se velozmente, como navios de guerra.

41. A princípio, víamos apenas duas ou três ilhas, mas daí a bocado surgiram umas seiscentas, que, colocando-se frente a frente, travaram uma batalha naval. Muitas chocavam-se de frente, e uma parte delas afundava-se após o choque, enquanto outras, mantendo-se acostadas entre si, lutavam valentemente, e não era fácil separarem-se. De facto, os que haviam formado à proa mostravam todo o seu ardor, abordando a outra ilha e dizimando gente. Ninguém fazia prisioneiros. Em vez de fateixas de ferro, lançavam enormes polvos enganchados uns nos outros, os quais, entrelaçados na mata, mantinham firme a ilha. Bombardeavam-se e feriam-se com ostras do tamanho de carroças e com esponjas do tamanho de um pletro ${ }^{191}$.

42. Comandavam-nos, a uns, Eolocentauro, aos outros Talassópotes ${ }^{192}$. Ao que parece, a guerra fora motivada por caso de roubo; dizia-se que Talassópotes havia roubado muitos rebanhos e golfinhos pertencentes a Eolocentauro - como se podia concluir, ouvindo-os injuriar-se mutuamente e invocar os nomes dos respectivos reis. Por fim, saíram vencedores os do lado de Eolocentauro, que afundaram cerca de cento e cinquenta ilhas e tomaram três, com a respectiva tripulação, enquanto os restante fizeram marcha à ré e fugiram. As outras ainda as perseguiram um bom bocado, mas, como se aproximava a noite, voltaram para trás, ao local do naufrágio, apoderaram-se da maior parte das coisas e recolheram também os seus destroços, pois da sua parte tinham-se igualmente afundado não menos de oitenta ilhas. Erigiram ainda um monumento triunfal em memória da nesomaquia ${ }^{193}$, plantando sobre a cabeça da baleia

${ }^{191} 1$ pletro $=400$ pés $=$ c. $120 \mathrm{~m}$.

192 Nem sempre é fácil «traduzir» estes nomes. Eolocentauro é algo como «Rápido-Centauro»; Talassópotes significa "Bebedor-do-Mar».

193 Nesomaquia, "combate entre ilhas», "isto é, "... de ilhas contra ilhas». Parece ser palavra forjada por Luciano, inspirada em naumaquia, «batalha naval», e similares. 
uma das ilhas inimigas. Naquela noite, acamparam à volta do monstro, amarrando-lhe cabos e lançando âncoras ali perto de facto, tinham âncoras de cristal, muito fortes.

No dia seguinte, celebraram um sacrifício em cima da baleia, sepultaram sobre ela os seus mortos e levantaram ferro, contentes e entoando como que hinos de vitória.

Eis, pois, a história da nesomaquia. 


\section{UMA HisTóRIA VERÍdica}

\section{LiVRo II}

1. A partir de então, não podendo mais suportar aquela vida dentro da baleia, e irritado com o lugar, tratei de procurar uma forma de podermos sair dali. A primeira ideia que nos ocorreu foi fazer um buraco do lado esquerdo do monstro e escapar-nos por aí, pelo que começámos a cavar. Tendo, porém, avançado qualquer coisa como 5 estádios ${ }^{194}$, sem nada conseguir, desistimos de escavar. Depois, decidimos pegar fogo à mata; dessa forma, talvez a baleia morresse, e, se tal acontecesse, tornar-se-ia mais fácil sair. Começámos, portanto, a fazer lume do lado da cauda e, durante sete dias e outras tantas noites, o animal ficou insensível ao fogo. Ao oitavo dia, porém, apercebemo-nos de que ele começava a ficar doente, pois era mais lento a abrir a boca e, quando a abria, logo a fechava. Ao décimo e décimo primeiro dias, já havia entrado nitidamente em decomposição e cheirava mal. Ao décimo segundo dia, apercebemo-nos, mesmo à justa, de que, se náo lhe escorássemos as mandíbulas enquanto a boca estivesse aberta, de forma que não voltasse a fechá-la, corríamos o risco de morrer encerrados dentro do cadáver. Assim, empámos-lhe a boca com enormes barrotes e tratámos de preparar o navio, nomeadamente com toda a água que pudemos carregar e as demais provisóes. Cíntaro fora designado como nosso piloto.

2. No dia seguinte (já a baleia estava morta e bem morta), empurrámos o barco rampa acima e fizemo-lo passar pelos intervalos; depois amarrámo-lo aos dentes do animal, e assim o fizemos descer suavemente até ao mar. Seguidamente, subimos para o lombo da baleia, oferecemos um sacrifício a Posídon e acampámos durante três dias mesmo ao pé do monumento triunfal - realmente, não havia vento. Ao quarto dia, fizemo-nos ao mar. No caminho, deparámos com grande quantidade de cadáveres da naumaquia, que nós abalroávamos. Ao medir-lhes os corpos, ficámos espantados ${ }^{195}$.

${ }^{194}$ c. $900 \mathrm{~m}$.

195 É curioso o facto de Luciano, neste caso, nem se dar ao trabalho de nos atirar com um número. 
Durante alguns dias navegámos com vento moderado, mas depois começou a soprar uma nortada muito forte e a fazer muito frio, que gelou todo o mar, não apenas em superfície, mas também até à profundidade de 400 braças $^{196}$, de forma que desembarcámos e nos pusemos a caminhar sobre o gelo. Como o vento persistia e náo podíamos aguentá-lo, imaginámos o seguinte estratagema (aliás foi Cíntaro quem teve a ideia): cavámos na água uma enorme caverna e ficámos lá dentro durante trinta dias, fazendo lume e alimentando-nos de peixe, que achávamos escavando. Como as provisóes estavam a faltar, saímos, desencalhámos o navio imobilizado pelo gelo, desfraldámos a vela, e assim começámos a avançar, como se navegássemos, deslizando suavemente e sem atrito por sobre o gelo. Ao quinto dia já fazia calor, pelo que o gelo começou a derreter e de novo se transformou todo em água.

3. Navegando cerca de 300 estádios $^{197}$, fomos aportar a uma ilha pequena e deserta, onde nos abastecemos de água (que já se nos havia esgotado) e caçámos dois touros selvagens, após o que nos fizemos ao mar. Ora, estes touros não tinham cornos na cabeça, mas sim abaixo dos olhos, como pretendia Momo ${ }^{198}$.

Não havia ainda decorrido muito tempo, penetrámos num mar, não de água, mas de leite. A certa altura, avistámos uma ilha branca e coberta de vinhas. Ora a ilha era toda ela um enorme queijo, bastante consistente, como mais tarde verificámos ao prová-la. $\mathrm{O}$ seu perímetro era de 25 estádios $^{199}$. As videiras estavam carregadas de cachos, mas o que bebíamos, espremendo as uvas, não era vinho, mas sim leite. No centro da ilha erguia-se um santuário dedicado à Nereida Galateia ${ }^{200}$, segundo rezava a inscrição.

Durante todo o tempo em que lá permanecemos, a terra fornecia-nos carne e páo, e, como bebida, o leite das uvas.

Reinava neste país - dizia-se - Tiro ${ }^{201}$, filha de Salmoneu, a qual, depois de deixar o nosso mundo, recebeu essa honra de Posídon.

${ }^{196}$ c. $700 \mathrm{~m}$.

197 c. $54 \mathrm{~km}$.

${ }^{198}$ Momo, filho da Noite, achava que o mundo está às avessas. Assim, os bois deviam ter os cornos onde pudessem vê-los; os homens deviam ter uma janela no peito, para que todos vissem o que ia por lá, no seu coraçáo; etc.

199 c. $4.5 \mathrm{~km}$.

${ }^{200}$ Os gregos ligavam o nome da ninfa ao substantivo gála, «leite».

201 Tyrô, Tiro (de tyrós, "queijo») é nome próprio feminino, como a da poetisa Safo, da ninfa Calipso, etc. 
4. Tendo permanecido cinco dias na ilha, ao sexto dia pusemo-nos a caminho, com uma leve brisa a acompanhar-nos e com ondulação suave. Ao oitavo dia (já não navegávamos através de leite, mas sim em água salgada e azul), avistámos muitos homens correndo sobre o mar, em tudo semelhantes a nós, tanto na forma do corpo como na estatura, apenas com excepçáo dos pés, que eram de cortiça, donde, julgo eu, lhes veio o nome de Felópodes ${ }^{202}$. Ficámos admirados ao ver que não iam ao fundo, mas se mantinham à superfície das ondas e caminhavam com à-vontade. Aproximaram-se de nós e saudaram-nos em língua grega. Também nos disseram que iam assim apressados para chegar a Felo ${ }^{203}$, sua pátria. Durante um certo tempo, acompanharam-nos, correndo ao nosso lado; depois, mudando de rota, desejaram-nos boa viagem e forram-se.

Passado pouco tempo, surgiram muitas ilhas. Mais próxima, à esquerda, Felo, para onde os tais se apressavam a ir, era uma cidade construída sobre uma cortiça gigantesca e redonda. Ao longe, e mais à direita, avistavam-se cinco ilhas muito grandes e montanhosas, donde se viam subir muitas labaredas. À proa, via-se uma ilha plana e baixa, distante náo menos de $500^{204}$ estádios.

5. Já estávamos próximo, quando começou a soprar sobre nós uma brisa maravilhosa, suave e perfumada, como aquela que o historiador Heródoto afirma que exalava da Arábia Feliz: tal qual um perfume de rosas, narcisos, jacintos, lírios e violetas, e, ainda, mirto, louro e flor de videira, assim chegava até nós este perfume agradável. Deliciados com o aroma, e esperando algo de bom depois de longas provaçóes, em breve estávamos perto da ilha. Avistámos muitos portos em toda a volta, abrigados e grandes, bem como rios límpidos que desaguavam suavemente no mar, e ainda prados e bosques, e aves canoras, que cantavam, umas nas margens, e outras - a maioria - sobre os ramos. Um ar leve e puro impregnava toda a região. E uma brisa, soprando agradavelmente, sacudia suavemente o bosque, de forma que da própria ramagem assim abanada se soltavam melodias encantadoras e contínuas, que faziam lembrar árias de flauta oblíqua, tocando em solo. Ouvia-se mesmo um coro, misturado e de fundo, não, porém, um barulho confuso, mas sim como aquele

202 Phellópodes, Felópodes, "Pés-de-Cortiça».

${ }^{203}$ Phellô, Felo, "(Ilha-de-)Cortiça», designação fictícia, mas... natural.

204 c. $500 \mathrm{~km}$. 
que se ouviria num banquete, com uns tocando flauta, outros cantando, outros marcando o ritmo à flauta ou à cítara.

6. Encantados com tudo isto, acostámos, lançámos âncora e desembarcámos, deixando no navio Cíntaro e dois ou três companheiros.

Ora, avançando nós através dum prado florido, deparámos com soldados e guardas da ronda, os quais nos amarraram com feixes de rosas (tal era, entre eles, a mais forte amarra) e nos conduziram ao seu chefe. Durante o caminho, soubemos por eles que a ilha se chamava "dos Bem-Aventurados», e que nela governava o cretense Radamanto ${ }^{205}$. Conduzidos à sua presença, ficámos em quarto lugar na fila dos que aguardavam julgamento.

7. A primeira audiência era dedicada a Ájax, filho de Télamon ${ }^{206}$, e a questão era se ele devia ou não ser incluído entre os heróis. Era acusado de ter perdido a razão e se ter suicidado. Por fim, depois de muita discussão, Radamanto ditou a sentença: para já, que fosse entregue ao médico Hipócrates de Cós, a fim de tomar eléboro $^{207}$; mais tarde, depois de recuperar a razão, que tomasse entâo parte no banquete.

8. O segundo julgamento era de natureza amorosa: Teseu e Menelau disputavam a respeito de Helena, e a questão era a de saber com qual dos dois ela deviam coabitar. Então Radamanto decidiu que ela vivesse com Menelau, atendendo a que este, por causa do casamento, havia sofrido muito e corrido muitos riscos; de resto, Teseu tinha à sua disposição outras mulheres, como Amazona e as filhas de Minos.

9. O terceiro julgamento era sobre a atribuição da presidência ${ }^{208}$ a Alexandre, filho de Filipe, ou a Aníbal, o cartaginês. $\mathrm{O}$ juiz decidiu em favor de Alexandre e mandou que lhe pusessem um trono ao lado do persa Ciro-o-Antigo.

${ }^{205}$ Um dos três juízes do Inferno. Os outros dois eram Minos e Éaco.

${ }^{206}$ Não confundir com Ájax, filho de Oileu, rei dos Lócrios, a que se faz referência no $\$ 17$.

207 eléboro ou heléboro, planta utilizada pelos antigos no tratamento de doenças nervosas, particularmente da loucura.

${ }^{208}$ Entenda-se: «do lugar da presidência», «do lugar proeminente». 
10. Em quarto lugar, fomos nós conduzidos. Então Radamanto perguntou-nos por que razão, estando nós ainda vivos, tínhamos vindo parar a uma região sagrada. Contámos-lhe de enfiada toda a nossa história, após o que ele, tendo-nos mandado retirar, ficou muito tempo a reflectir e a consultar os seus assessores sobre o nosso caso (assistiam-no, entre muitos outros, Aristides, o Justo, de Atenas). Uma vez tomada a decisão, ditou a sentença: pelo nosso gosto de aventura e consequentes errores, prestaríamos contas quando morrêssemos; por agora, porém, permaneceríamos na ilha por um tempo determinado e levaríamos a mesma vida que os heróis, após o que partiríamos. Foi fixado para a nossa estada ali um período máximo de sete meses.

11. Imediatamente se soltaram por si mesmas as amarras que nos envolviam, e ficámos livres. Seguidamente, fomos conduzidos à cidade e ao banquete dos bem-aventurados. Ora, esta cidade era toda em ouro, e a muralha à volta era de esmeraldas. Tinha sete portas, todas de uma só peça em madeira de canela. Quanto ao chão da cidade e ao piso no interior da muralha, era de marfim. Os templos de todos os deuses são construídos em berilo, e os seus altares são enormes monólitos de ametista, sobre as quais executam as hecatombes ${ }^{209}$. À volta da cidade corre um rios da mais bela mirra, com uma largura de cem côvados reais ${ }^{210}$ e uma profundidade de $\operatorname{cinco}^{211}$, de forma que se podia nadar à vontade. Também têm balneários, que são grandes edifícios em vidro, aquecidos com madeira de canela. Em vez de água, as banheiras contêm orvalho quente.

12. Como vestuário, utilizam finas teias de aranha, cor de púrpura. As pessoas, propriamente, náo têm corpo, mas antes são impalpáveis e sem carne: o que se vê é apenas a forma e a silhueta. $\mathrm{O}$ facto de serem incorpóreos não obsta, porém, a que se mantenham de pé, se movimentem, pensem e falem; em suma: é como se as suas almas, despojadas de matéria, deambulassem exactamente com a forma exterior do corpo. Realmente, se não se lhes tocasse, ninguém diria que não era um corpo aquilo que se via, pois sáo

${ }^{209}$ Uma hecatombe significava, inicialmente, um «sacrifício de cem bois»; em breve, porém (como era natural...), passa a significar «sacrifício importante».

${ }^{210}$ c. $44 \mathrm{~m}$.

${ }^{211}$ c. $2,2 \mathrm{~m}$. 
como sombras de pé, mas não escuras. Nenhum deles envelhece, mas antes continuam com a idade que tinham ao chegar. Naquele sítio nunca é de noite, nem, aliás, completamente de dia: tal como a claridade da aurora, momentos antes de nascer o sol, assim é a luz que cobre aquela terra. Além disso, só conhecem uma estação do ano: ali é sempre primavera, e sopra um só vento, o zéfiro.

13. Aquela terra é fértil em toda a espécie de flores e toda a casta de árvores, tanto de fruta como se sombra. As videiras produzem doze vezes no ano, pelo que as vindimam uma vez por mês, enquanto - segundo dizem - as romázeiras, as macieiras e as outras árvores de fruto produzem treze vezes: de facto, num dos meses (a que lá chamam «Minoês»" ${ }^{212}$ ), frutificam duas vezes. Em vez de grãos, as espigas dão pães já prontos, que nascem na sua extremidade, como se fossem cogumelos. À volta da cidade existem 365 nascentes de água, outras tantas de mel e 500 de mirra, sendo estas, no entanto, mais pequenas; há também sete rios de leite e oito de vinho.

14. Fazem o banquete fora da cidade, na chamada Planície Elísia, que é um lindíssimo prado, atravessado por um bosque espesso, com toda a espécie de árvores, que dá sombra aos comensais. Estendem no chão um tapete de flores, e são os ventos que os servem e lhes trazem cada coisa, só não lhes vazando o vinho, que não têm necessidade disso, porquanto, em toda a extensão do local do banquete, há umas árvores enormes, de vidro do mais transparente: os frutos destas árvores são taças de todo o género, tanto na forma como no tamanho. Ao chegar ao banquete, uma pessoa colhe uma ou duas dessas taças e coloca-as à sua frente, ficando imediatamente cheias de vinho. É assim que eles bebem. Em vez de coroas, os rouxinóis e as demais aves canoras colhem com os bicos flores dos prados vizinhos e, voando sobre as pessoas e trinando, fazem-nas cair como neve. E perfumam-se do modo seguinte: umas nuvens espessas sugam mirra das fontes e do rio; depois, pairando sobre o local do banquete, e ao leve sopro dos ventos, fazem cair uma chuva miudinha como orvalho.

15. Durante o jantar, entretêm-se com música e cantares. Cantam-lhes especialmente trechos de Homero, o qual está presente em pessoa e se diverte com eles, reclinado ao lado de Ulisses.

${ }^{212}$ Quer dizer: «dedicado a Minos». 
Os coros, de rapazes e de raparigas, são dirigidos por Êunomo de Locros, Aríon de Lesbos, Anacreonte e Estesícoro. Sim, entre eles vi também este último, com o qual Helena já estava reconciliada $^{213}$. Logo que eles acabaram de cantar, entrou um segundo coro, formado por cisnes, andorinhas e rouxinóis. E enquanto estes cantam, todo o bosque os acompanha, sob a direcçáo dos ventos.

16. Mas a coisa que mais faz as suas delícias é a seguinte: existem duas fontes junto ao local do banquete - uma de riso e outra de prazer. Toda a gente, no começo da funçáo, bebe duma e doutra, pelo que passam o resto do tempo satisfeitos e sorridentes.

17. Quero agora referir as personalidades célebres que vi entre eles: todos os heróis e guerreiros que combateram junto de Ílion ${ }^{214}$, apenas com excepção do locriense Ájax ${ }^{215}$ (dizia-se que fora ele o único a ser punido na zona dos ímpios). De entre os bárbaros, [vi] os dois Ciros e o cita Anacársis e o trácio Zanólxis e Numa o Italiota, e ainda Licurgo da Lacedemónia, e os atenienses Fócion e Telo, bem como os [sete] sábios, com excepção de Periandro. Vi também Sócrates, filho de Sofronisco, que cavaqueava com Nestor e Palamedes. Perto dele encontravam-se Jacinto, o Lacedemónio, Narciso de Téspis, Hilas e outras beldades do género. Tive mesmo a impressão de que Sócrates estava apaixonado por Jacinto: pelo menos, era a este que ele fazia a maior parte das objecçóes. Dizia-se até que Radamanto estava zangado com ele e que muitas vezes tinha ameaçado expulsá-lo da ilha, se continuasse a tagarelar e náo resolvesse pôr de parte a ironia e divertir-se. Só lá não estava Platão, pois, segundo se dizia, esse habitava na cidade por ele próprio imaginada, aplicando a Constituição e as leis que havia redigido ${ }^{216}$

18. Aristipo e Epicuro, juntamente com os respectivos discípulos, levavam a palma a todos, sendo, como eram, pessoas agradáveis, risonhas e excelentes bebedores. Também lá estava o

${ }^{213}$ Por ter censurado Helena em termos muito violentos, Estesícoro foi cegado por Castor e Pólux. Mais tarde, retractou-se e recuperou a vista.

214 Ílion é outro nome de Tróia.

${ }^{215}$ Diferente de Ájax, filho de Télamon, rei de Salamina, referido do $\$ 7$. O Ájax locriense cometeu actos sacrílegos, que suscitaram a ira dos deuses.

${ }^{216}$ Referência à República de Platão, uma das utopias («não lugares») da literatura universal. 
frígio Esopo, que eles utilizavam na função de bobo; e Diógenes de Sinope, o qual havia mudado tăo radicalmente o seu carácter, que não só casara com a meretriz Laida ${ }^{217}$, como até, sob o efeito do álcool, se levantava para dançar e fazia coisas incríveis. Dos estóicos não estava nenhum: é que, ao que se dizia, ainda andavam a escalar a escarpada montanha da virtude. De Crisipo, ouvimos dizer que não era autorizado a desembarcar na ilha, sem que primeiro se submetesse a quatro tratamentos com eléboro ${ }^{218}$. Quanto aos académicos, dizia-se que queriam vir... só que... ainda estavam hesitantes, a reflectir sobre o assunto: na realidade, ainda não tinham chegado a qualquer conclusão sobre a magna questão de saber se uma tal ilha existia mesmo. Ora, a meus ver, trata-se mas é doutra coisa: o que eles têm é medo do julgamento de Radamanto, uma vez que eles próprios negam a possibilidade de julgar. Afirmava-se que muitos deles, embora tivessem tentado seguir os que para aí se dirigiam, haviam, porém, desistido, devido à sua lentidão, que não os deixava acompanhá-los, pelo que, a meio do caminho, voltavam para trás.

19. Tais eram, dos presentes, as personalidades mais dignas de nota. Mas particularmente estimado é Aquiles e, logo a seguir, Teseu. No que toca a ligaçóes amorosas e sexo, eis a sua concepção: têm relaçōes às claras, à vista de todos, tanto com mulheres como com homens, coisa que de modo algum consideram vergonhosa. Apenas Sócrates jurava a pés juntos que o seu contacto com os jovens era puro, mas a verdade é que todos o acusavam de perjúrio, porquanto, em muitas ocasióes, tanto Jacinto como Narciso o haviam confessado, mas ele negava. Por seu lado, as mulheres são comuns a todos, e ninguém tem inveja da do vizinho: neste aspecto, são absolutamente platónicos ${ }^{219}$. Quanto aos adolescentes. oferecem-se ao primeiro que aparece, sem qualquer objecção.

20. Ainda não tinham decorrido dois ou três dias, fui procurar o poeta Homero, que tinha o tempo livre, tal como eu. Entre

217 Laida ou, tirado do nominativo, Lais. Na Antologia Grega (VII, 220), lê-se um epigrama funerário dedicado a esta famosa meretriz: «... Ah! Quanto afligiste o coração dos jovens!...».

218 eléboro ou heléboro, planta utilizada pelos antigos no tratamento de doenças nervosas, particularmente da loucura.

219 Trata-se da doutrina "comunista» de Platão, já exposta na Assembleia das Mulheres de Aristófanes: comunidade de bens e de mulheres. 
outras coisas, perguntei-lhe donde era ele natural, acrescentando que esse ponto continua a ser, ainda hoje entre nós, matéria de grande polémica. Ele próprio afirmou não desconhecer que uns o julgavam natural de Quios, outros de Esmirna, muitos de Cólofon. No entanto, contou que era babilónio e que, entre os seus concidadãos, não se chamava Homero, mas Tigranes; mais tarde é que, já na condição de refém dos gregos, mudou de nome ${ }^{220}$. Também lhe perguntei, a respeito dos versos tidos por apócrifos, se tinham sido escritos por ele, ao que me respondeu que sim, que eram todos dele. Daí que eu condenasse o excessivo pedantismo dos gramáticos Zenódoto, Aristarco e companhia. Dada resposta suficiente a estas questóes, coloquei-lhe outra pergunta: por que motivo iniciou o poema ${ }^{221}$ pela cólera [de Aquiles]. Disse ele que foi assim que lhe ocorrera ao espírito, que não houvera da sua parte qualquer intenção premeditada. Também pretendi saber outra coisa: se de facto escrevera a Odisseia antes da Ilíada, como muitos afirmam. Ele, porém, negou. E mais: que ele nem sequer era cego (coisa que a seu respeito se diz), fiquei imediatamente a sabê-lo: eu próprio o constatei, sem necessidade de perguntar. Aliás, muitas vezes, sempre que via que ele tinha tempo livre, era assim que eu fazia; de facto, se me aproximava para lhe perguntar alguma coisa, ele a tudo respondia de boa vontade, especialmente se o assunto era o processo que ele havia ganho. Tratava-se dum processo de difamaçáo que contra ele intentara Tersites, pelo facto de ter troçado dele no seu poema - processo que Homero venceu e no qual Ulisses fora seu advogado.

21. Justamente por esta altura, chegou Pitágoras de Samos, o qual já havia passado por sete metamorfoses e vivido em outros tantos seres, e que havia terminado o ciclo da alma ${ }^{222}$. A metade direita do seu corpo era toda em ouro. Embora o tribunal o tivesse julgado digno de partilhar da vida deles, ficara pendente a questão de saber se o deviam tratar por Pitágoras ou por Euforbo.

${ }^{220}$ Como se vê, a "questão homérica» já vem da Antiguidade. Luciano dá para o problema uma "contribuição» jocosa, só para baralhar ainda mais. O resto da conversa do narrador com Homero vai no mesmo sentido.

${ }^{221}$ Refere-se à Ilíada, como se vê pela sequência.

222 Trata-se da célebre doutrina da transmigração das almas ou metempsicose. 
Também veio Empédocles, todo queimado e com o corpo completamente grelhado, mas não o acolheram, apesar das suas insistentes súplicas.

22. O tempo ia passando, até que chegou a altura dos jogos, que lá se chamam Tanatúsicos ${ }^{223}$. A função de agonóteta ${ }^{224}$ era desempenhada por Aquiles, pela quinta vez, e por Teseu, pela sétima. Seria, porém, muito longo narrar tudo aquilo, pelo que contarei apenas os aspectos principais.

$\mathrm{Na}$ luta, saiu vencedor Carano, descendente de Héracles, que tinha Ulisses como adversário na conquista da coroa. No pugilato, verificou-se um empate entre o egípcio Ario, que está sepultado em Corinto, e Epio, que se defrontaram.

Quanto ao pancrácio, não se realiza lá; e, no que toca à corrida, já não me lembro quem venceu. E quanto aos poetas, muito embora Homero fosse de longe superior, quem ganhou foi Hesíodo 225 .

O prémio era, para todos, uma coroa feita de penas de pavão.

23. Mal os jogos haviam terminado, eis que chega a notícia de que os supliciados da regiáo dos ímpios haviam rebentado com os grilhôes, tinham dominado os guardas e marchavam sobre a ilha, comandados por Fálaris de Agrigento, o egípcio Busíris, o trácio Diomedes e ainda Escíron e Pitiocamptes. Logo que soube disso, Radamanto fez alinhar na praia os heróis, que eram comandados por Teseu, Aquiles e Ájax Telamónio (este já havia recuperado a razão). Da refrega saíram vencedores os heróis de Aquiles, o qual realizou muitas façanhas. Também se distinguiu Sócrates, na ala direita, e muito mais até do que quando combateu em Délio ${ }^{226}$ : de facto, confrontado com quatro inimigos, não fugiu, mas manteve uma expressão inalterável. Mais tarde, pela sua actuação, foi-lhe atribuído, como prémio, um belo e enorme jardim nos arredores, onde reunia os seus companheiros e com eles discutia. A este lugar deu ele o nome de Necracademia ${ }^{227}$.

${ }^{223}$ Quer dizer: «Jogos dos Mortos», em nítida alusão aos Jogos Olímpicos».

224 «Presidente dos jogos públicos».

225 É muito curiosa esta provocatória atribuição de vitória a Hesíodo...

226 Cidade da Beócia.

227 Platão leccionava na Academia ou Jardim de Academo. É natural que o jardim atribuído a Sócrates se chame Necracademia, "Academia dos Mortos». 
24. Uma vez derrotados [os insurrectos], puseram-nos a ferros e recambiaram-nos, a fim de serem castigados ainda mais severamente. Homero celebrou esta batalha e, no momento em que eu deixava a ilha, entregou-me o livro, para que eu o transmitisse aos homens da nossa terra. Mais tarde, porém, perdi-o, juntamente com outras coisas. $\mathrm{O}$ começo do poema era assim:

Agora, Musa, conta-me dos heróis defuntos a batalha.

Em seguida, cozeram favas, segundo é costume entre eles quando ganham uma guerra, e assim celebraram o banquete triunfal e fizeram uma grande festa, na qual só não participou Pitágoras, que se manteve à distância, sem comer, pois detestava favadas ${ }^{228}$.

25. Já tinham decorrido seis meses, e eis que, a meio do sétimo, surgiram novas complicações: Cíniras, filho de Cíntaro, moço alto e formoso, já há muito que estava apaixonado por Helena, a qual, por seu lado, não disfarçava o seu louco amor pelo jovem. Muitas vezes, mesmo, durante o banquete, faziam sinais um ao outro, bebiam à saúde um do outro, levantavam-se e iam sozinhos passear pelo bosque. Um belo dia, Cíniras, levado pela paixão e pelo desespero, resolveu raptar Helena - aliás com o consentimento desta - e fugir [com ela] para uma das ilhas vizinhas, concretamente para Felo ou Tiroessa ${ }^{229}$. Há muito tempo que haviam assegurado a cumplicidade de três dos nossos companheiros mais destemidos. No entanto, não comunicou os seus planos ao pai, pois sabia que este o impediria. Quando lhes pareceu o momento oportuno, puseram o plano em execução. Chegada a noite - eu não estava presente, pois dera-se o caso de ter adormecido no banquete -, iludindo os outros, levaram Helena e fizeram-se ao mar a toda a pressa.

26. Por volta da meia-noite, Menelau acordou e, verificando que o leito de sua mulher estava vazio, deu o alarme; depois, juntamente com seu irmáo, foi ter com o rei Radamanto.

Ao romper do dia, os vigias comunicaram que avistavam o navio lá muito ao longe. Então Radamanto mandou embarcar

228 «Abstém-te de favas» era uma das normas pitagóricas, que nada tem que ver com motivaçôes pitagóricas, mas cujo sentido íntimo nos é obscuro.

${ }^{229}$ Respectivamente "Ilha-Cortiça» e «Ilha-Queijo». 
cinquenta heróis num barco feito de caules de asfódelo ${ }^{230}$, e ordenou-lhes que perseguissem [os fugitivos]. Avançando com entusiasmo, por volta do meio-dia foram alcançá-los, justamente no momento em que eles penetravam na parte leitosa do oceano, perto de Tiroessa. Por pouco que conseguiam escapar. Então amarraram o navio com uma corda de roseira e regressaram. E enquanto Helena chorava e cobria o rosto com vergonha, Radamanto começou por interrogar Cíniras e os companheiros, [para saber] se mais alguém estava implicado no caso. Tendo eles respondido negativamente, prendeu-os pelas partes viris e enviou-os para o território dos ímpios, não, porém, sem que primeiro os mandasse açoitar com malvas.

27. Decidiram, também, expulsar-nos da ilha antes do prazo, permitindo-nos apenas aguardar pelo dia seguinte. Então eu comecei a lamentar-me e a chorar pela felicidade perdida e pela vida errante a que estava destinado. Eles, porém, consolavam-me, dizendo que dentro de náo muitos anos regressaria para junto deles; chegaram mesmo a mostrar-me o meu futuro assento e o meu lugar à mesa junto dos mais famosos. Depois fui procurar Radamanto w supliquei-lhe encarecidamente que me revelasse o futuro e me indicasse a rota. Garantiu-me que chegaria à minha pátria, mas que primeiro teria de vaguear longamente e correr muitos perigos. Só náo quis concretizar quanto tempo duraria a viagem de regresso. No entanto, apontando-me as ilhas vizinhas - das quais se avistavam cinco, havendo ainda uma sexta mais longe -, disse que umas, as que ficavam mais perto, eram as ilhas dos ímpios, "onde - disse - estás vendo um grande fogo a arder; aquela outra, a sexta, é a cidade dos sonhos; a seguir a esta, fica a ilha de Calipso, que ainda não é visivel. Depois de passares estas ilhas, chegarás ao grande continente fronteiro à terra habitada por vós; após passardes ai por muitas provaçóes, e depois de terdes atravessado variadas naçôes e entrado em contacto com homens hostis, chegareis enfim, com o tempo, ao outro continente."

28. Assim falou, após o que, tendo arrancado da terra uma raiz de malva, ma ofereceu, recomendando-me que fizesse a esta as minhas preces nos grandes momentos de perigo. Também me aconselhou a que, se alguma vez chegasse a essa terra, nunca

${ }^{230} \mathrm{O}$ asfódelo é uma planta liliácea. O barco que Luciano idealiza devia ser construído com um entrelaçado de caules desta planta. Quem duvida? 
ateasse lume com uma espada, nem comesse tremoços, nem tivesse relações com um jovem maior de dezoito anos; se me lembrasse destes conselhos, poderia ter esperança de chegar à tal ilha.

Comecei então a fazer os preparativos para a viagem. Logo que chegou o momento oportuno, fui ter com eles ao banquete. No dia seguinte, dirigi-me ao poeta Homero e pedi-lhe que me fizesse um dístico epigramático; logo que o fez, gravei-o numa coluna de berilo, que erigira junto do porto. A inscrição dizia assim:

\section{Luciano, querido dos deuses bem-aventurados, esta terra visitou e depois partiu para a sua querida pátria.}

29. Tendo aí permanecido aquele dia, no seguinte levantei ferro, com os heróis a acompanhar-nos até à margem. Aí Ulisses, às escondidas de Penélope, aproximou-se de mim e entregou-me uma carta para eu levar à ilha de Ogígia, a Calipso. Quanto a Radamanto, dispensou-me o piloto Náuplio, a fim de que, no caso de desembarcar nas ilhas, ninguém nos prendesse, na suposição de que vínhamos com qualquer outra intenção.

Ora, avançando sempre, já havíamos ultrapassado a zona da atmosfera bem-cheirosa; então, eis que começámos a sentir um cheiro horrendo, como que de asfalto, enxofre e pez, tudo a arder ao mesmo tempo, bem como um pivete horrível e insuportável, como que de pessoas grelhadas; o céu apresentava-se escuro e brumoso, e caía dele um orvalho de pez; ouvíamos também um som de chicotes e uns gemidos de muita gente.

30. Das outras ilhas não nos aproximámos, mas esta em que desembarcámos era como segue: à volta, era toda ela escarpada e desnudada, e eriçada de penedos e ravinas; não havia nela qualquer árvore, nem água; mesmo assim, trepámos até ao alto das falésias, após o que avançámos por uma vereda semeada de espinhos e paliçadas. A terra era realmente muito feia. Chegados à prisão e local de suplícios, ficámos imediatamente espantados com a natureza do lugar: na verdade, do próprio chão tinham nascido espadas e lanças por todo o lado, e à volta corriam uns rios, um de lama, o segundo de sangue, e o do meio de fogo, sendo este muito grande e impossível de atravessar; corria como água, tinha ondas como o mar, e muitos peixes, parecidos uns com tochas, e outros, pequenos, com carvôes incandescentes, a que chamavam «lamparinas» ${ }^{231}$.

${ }^{231} \mathrm{Ou}$ "pequenas candeias»(kykhniskoi). 
31. Havia uma entrada, mas estreita, por entre eles todos; aí estava postado, como porteiro, Tímon de Atenas. No entanto, sob a orientação de Náuplio, lá passámos; e vimos a serem punidos muitos reis e muitos simples cidadãos, de entre os quais reconhecemos mesmo alguns. Vimos, entre outros, Cíniras pendurado pelas partes viris e sufocado pelo fumo. Os nossos guias iam narrando a vida de cada um deles e os crimes pelos quais eram punidos. De entre todos, os que maiores castigos sofriam eram os que, ao longo da vida, tinham sido mentirosos, bem como os que não haviam escrito a verdade ${ }^{232}$; entre eles contavam-se Ctésias de Cnido, Heródoto ${ }^{233}$ e muitos outros. Ao vê-los, enchi-me de boas esperanças quanto ao meu futuro, porquanto tinha a consciência de nunca ter dito nenhuma mentira.

32. Entáo voltei imediatamente para o navio (pois náo podia suportar o espectáculo), despedi-me de Náuplio e parti de novo.

Daí a pouco, aparecia-nos, a pequena distância, a ilha dos Sonhos, envolta em bruma e mal se vendo; passava-se com ela algo de muito semelhante aos sonhos, pois afastava-se à medida que nós nos aproximávamos, depois esvaía-se, para emergir mais adiante. Por fim, conseguimos atingi-la e desembarcámos no porto do Sono, indo acostar perto das portas de marfim, em cuja zona se encontra o santuário do Galo. Desembarcámos já noite cerrada. Ao percorrermos a cidade, deparámos com muitos e variados sonhos. Mas, antes de mais, quero falar da cidade, já que ela não ficou descrita por mais ninguém: apenas Homero lhe faz referência, mas o que escreve não é muito exacto ${ }^{234}$.

33. A toda a volta dessa ilha há uma floresta, mas as árvores são dormideiras enormes e mandrágoras, e sobre elas encontrava-se uma grande quantidade de morcegos. Realmente, é esta a única ave $\mathrm{e}^{235}$ existente na ilha. Perto da cidade corre um rio, a que eles chamam Sonâmbulo ${ }^{236}$; e junto às portas há duas fontes: uma

${ }^{232} \mathrm{O}$ narrador refere-se tanto aos que tinham mentido por palavras, como aos escritores de patranhas.

233 Já desde a Antiguidade, Heródoto era tido por muitos como um grande contador de histórias fantásticas e de mentiras (como o nosso Fernão Mendes Pinto: Fernão, mentes? - Minto!).

${ }^{234}$ Homero $(O d$., XIX, 560, ss.) fala de apenas duas espécies de sonhos e de duas portas. Luciano, porém, repóes a verdade dos factos!

235 Temos de desculpar a confusão...

${ }^{236}$ Nyktipóros, Nictíporo. 
tem o nome de Sonolenta ${ }^{237}$; a outra chama-se Toda-a-Noite ${ }^{238}$. A muralha da cidade é alta e de cores variegadas, semelhantes às do arco-íris; quanto às portas, não são duas, como diz Homero, mas quatro: duas viradas à planície da Indolência ${ }^{239}$, sendo uma feita de ferro e outra de barro: é por elas, que, segundo se diz, saem os sonhos aterradores, os sanguinários e os obscenos; as outras duas dáo para o porto e para o mar, sendo uma de corno e a outra (aquela por onde nós entrámos) de marfim. À direita de quem entra na cidade, fica o Templo- da-Noite ${ }^{240}$ : de facto, é esta, de entre as divindades, aquela que eles mais veneram, bem como o Galo ${ }^{241}$, cujo santuário se ergue próximo do porto, À esquerda, fica o palácio do Sono ${ }^{242}$. $\mathrm{Na}$ verdade, é este quem reina lá, com dois sátrapas ${ }^{243}$ colocados na sua dependência: Pesadelo ${ }^{244}$, filho de Futiliano ${ }^{245}$, e Fortunato $^{246}$, filho de Fantasiáo ${ }^{247}$. A meio da praça existe uma fonte chamada da Modorra ${ }^{248}$, e perto dela há dois templos: o da Mentira ${ }^{249}$, e o da Verdade ${ }^{250}$. Aí têm eles o santuário e o oráculo, à frente do qual está o profeta Antifonte, intérprete dos sonhos, que recebeu esse honroso cargo das máos do próprio Sonho ${ }^{251}$.

34. No que respeita aos sonhos, tanto a sua natureza como a sua forma não são iguais, mas antes, enquanto uns eram grandes, belos e agradáveis à vista, outros eram pequenos e feios, outros doirados, e outros ainda humildes e de pouco valor. Entre eles, havia alguns alados e monstruosos, enquanto outros estavam ataviados como que para

237 Nêgretos, Négreto, "que não se pode acordar»...

${ }^{238}$ Pannukhia, Paníquia.

239 Blakeia, Blacia.

${ }^{240}$ Nyktôon, Nictoo.

241 Alektryôn, Aléctrion.

${ }^{242}$ Hýpnos, Hipno.

243 Governadores de Província, na Pérsia... e não só...

244 Taraxiôn, Taráxion.

245 Mataiogénês, Mateoógenes, de mátaios, "fútil». A «tradução» deste e doutros nomes é particularmente difícil. É claro que não existe port. futiliano.

246 Ploutoklês, Plútocles, de ploutos, "riqueza».

247 Phantasiôn, Fantásion, de phantasía, "fantasia»...

${ }^{248}$ Kareôtis, Careótis, nome fictício, que faz referência a algo como "cabeça pesada", a cair de sono...

${ }^{249}$ Apátê, Ápate.

250 Alètheia, Aletia.

251 Hýpnos, Hipno. 
uma procissão: uns, vestidos de reis, outros de deuses, outros de diversas personagens. Muitos deles reconhecemo-los nós, por já alguma vez os termos visto na nossa terra; estes aproximaram-se de nós, saudaram-nos como o fariam pessoas das nossas relaçôes, levaram-nos com eles, proporcionaram-nos um sono excelente, enfim, hospedaram-nos muito bem; e, além de nos terem preparado uma recepção magnífica, prometeram fazer de nós reis e sátrapas. Alguns chegaram mesmo a conduzir-nos à nossa pátria, mostraram-nos os nossos familiares e, no mesmo dia, trouxeram-nos de volta.

35. Permanecemos com eles trinta dias e outras noites, tendo dormido regaladamente. Então, eis que de repente estala um enorme trovão: acordados em sobressalto, corremos para bordo, não sem antes termos arranjado provisóes.

A três dias de viagem dali, aportámos à ilha de Ogígia, onde desembarcámos. A primeira coisa que fiz foi abrir a carta e ler o seu conteúdo, que era o seguinte:

"Ulisses saúda Calipso. Faço-te sabedora de que, pouco depois de haver partido dai na jangada por mim construida, fui vítima dum naufrágio, sendo salvo, a custo, por Leucótea ${ }^{252}$ e levado para o país dos Feaces ${ }^{253}$, os quais me proporcionaram o regresso à pátria, onde deparei com uma legião de pretendentes de minha mulher, e que gozavam do que era meu. Tendo-os liquidado a todos, mais tarde, porém, acabei por ser morto por Telégono ${ }^{254}$, um filho que tive de Circe. Agora encontro-me na ilha dos Bem-Aventurados, bem arrependido de ter abandonado a vida que levava na tua companhia, bem como a imortalidade que me havias prometido. Se algum dia tiver oportunidade, fujo daqui e vou ter contigo."

Eis, pois, o que dizia a carta, e ainda, no que nos dizia respeito, solicitava que nos acolhesse.

${ }^{252}$ Leucótea, "deusa branca», divindade marinha, antes chamada Ino; tinha o poder de apaziguar as tempestades.

${ }^{253}$ Referência ao conhecido episódio do canto VI e ss. da Odisseia.

${ }^{254}$ Este episódio dramático da mitologia grega resume-se no seguinte: Criado por Circe, sua mãe, Telégono partiu um dia para Ítaca, com alguns companheiros, a fim de ser reconhecido por seu pai, Ulisses. Tendo invadido e pilhado as terras que náo sabia serem do pai, entrou em luta com os habitantes de Ítaca, comandados precisamente por Ulisses, a quem matou com uma seta de espinhas de raia, assim se cumprindo o oráculo, que dizia que Ulisses havia de ser morto no mar (é aqui que entram as setas de raia), às mãos do próprio filho. 
36. Tendo-me afastado um pouco do mar, encontrei a tal gruta, como Homero a descreveu, bem como a própria Calipso, que estava a fiar. Entáo ela pegou na carta e, mal acabou de a ler, irrompeu num longo choro; depois pediu-nos que aceitássemos a sua hospitalidade, ofereceu-nos um banquete magnífico e não cessava de perguntar coisas a respeito de Ulisses e de Penélope, nomeadamente como era ela fisicamente, e se era assim tão sensata como Ulisses em tempos a gabava. Nós, é claro, respondemos consoante nos parecia ser do seu agrado. Depois voltámos para junto do navio e dormimos perto dele, sobre o areal.

37. De manhã, com uma brisa algo forte, fizemo-nos ao mar. Fustigados durante dois dias por uma tempestade, ao terceiro fomos dar ao país dos Aboboropiratas ${ }^{255}$ : trata-se de gentes selvagens, que, a partir das ilhas próximas, assaltam os que por ali navegam. Possuem grandes barcos feitos de abóbora, de 60 côvados ${ }^{256}$ de comprimento. Efectivamente, póem uma abóbora a secar, após o que a escavam; retirado o miolo, póem-na a navegar. Utilizam mastros de cana e, a fazer de vela, a folha da abóbora. Lançaram-se sobre nós e atacaram-nos com dois navios e feriram muitos dos nossos, atirando-nos, em vez de pedras, com muitas pevides de abóbora. Depois de muito pelejarmos sem resultado, eis que, por volta do meio-dia, avistámos, por detrás dos Aboboropiratas, e navegando em nossa direcçáo, os Marinheiros-das-Nozes ${ }^{257}$. Ora, sucedia que eram inimigos uns dos outros, como se demonstrou, porquanto, mal os nossos adversários se aperceberam da chegada dos outros, desinteressaram-se de nós e, dando meia volta, passaram a lutar contra eles.

38. Entretanto nós içámos a vela e pusemo-nos em fuga, deixando-os a lutar; aliás, era manifestamente previsível a vitória dos Marinheiros-das-Nozes, já por serem mais numerosos (de facto, tinham cinco guarniçôes), já por combaterem em navios mais robustos. Na verdade, os seus barcos eram meias cascas de nozes esvaziadas, medindo cada uma para aí 15 braças $^{258}$ de comprimento. Assim que deixámos de os ver, começámos a tratar dos feridos; mas daí em diante estávamos

${ }^{255}$ Kolokynthopeiratai, Colocintopiratas.

256 c. $30 \mathrm{~m}$.

257 Karyonautai, Carionautas.

258 c. $27 \mathrm{~m}$. 
sempre com as armas à mão e prontos para a eventualidade de qualquer ataque. E náo foi em vão.

39. De facto, ainda não se tinha posto o sol, e eis que duma ilha isolada avançam sobre nós cerca de vinte homens montados em enormes golfinhos; eram também eles piratas. Os golfinhos transportavam-nos com segurança e, enquanto saltavam, relinchavam como cavalos. Quando já estavam perto, separaram-se e, uns por um lado, outros por outro, atacaram-nos com cartilagens de chocos e olhos de caranguejos. Apesar de tudo, não resistiram às nossas flechas e aos nossos dardos, pelo que tiveram de se refugiar na ilha, com a maior parte deles feridos.

40. Cerca da meia-noite, e com o tempo calmo, fomos parar, sem disso nos apercebermos, a um enorme ninho de alcíone $e^{259}$, o qual tinha de perímetro 60 estádios $^{260}$. A fêmea, que não era muito mais pequena que o ninho, vogava sobre ele, chocando os ovos. Ora, tendo ela levantado voo, pouco faltou para afundar o nosso barco, tal a deslocação de ar provocada pelo bater de asas; mas o certo é que se pôs em fuga, lançando como que um guincho choroso. E foi já ao despontar do dia que desembarcámos, constatando que o ninho se parecia com uma enorme jangada feita de grandes árvores unidas umas às outras; havia nele quinhentos ovos, cada um maior que um tonel de Quios; e até já se viam no interior os passarinhos, que piavam. Quebrámos à machadada um dos ovos e dele retirámos um pássaro sem penas, mas mais corpulento que vinte abutres.

41. Continuando a nossa viagem, e quando já estávamos afastados do ninho cerca de 200 estádios $^{261}$, fomos testemunhas de grandes e maravilhosos prodígios: de súbito, o ganso que ornamentava a proa do nosso navio ganhou penas [verdadeiras] e começou a grasnar; ao nosso piloto Cíntiro, que já era calvo, cresceu-lhe de novo o cabelo; e - o mais estranho de tudo o mastro do navio deu em espigar e cresceram-lhe pernadas, as pontas das quais começaram a florir, e depois os frutos eram figos e uvas pretas, ainda não completamente maduros. À vista destas maravilhas, ficámos perturbados, como era natural, e

${ }^{259}$ Ave fabulosa, identificada com o cisne, a gaivota, o maçarico, etc.

260 c. $10,5 \mathrm{~km}$.

${ }^{261}$ c. $36 \mathrm{~km}$. 
fizemos uma prece aos deuses, por causa de fenómenos táo estranhos.

42. Ainda não tínhamos percorrido 500 estádios ${ }^{262}$, deparámos com uma floresta de pinheiros e ciprestes, enormíssima e espessa. De facto, imaginámos tratar-se dum continente, mas era apenas um mar profundo, semeado de árvores sem raízes, as quais árvores, no entanto, se mantinham de pé, imóveis e direitas, como se flutuassem. Entáo aproximámo-nos e, compreendendo tudo, ficámos embaraçados, sem saber o que devíamos fazer, porquanto nem era possível navegar pelo meio das árvores, por estas serem frondosas e estarem muito juntas umas das outras, nem se nos afigurava fácil voltar para trás. Então subi à árvore mais alta, a fim de inspeccionar como era lá para diante; e verifiquei que a floresta se estendia por 50 estádios $^{263}$ ou pouco menos, e que logo a seguir se sucedia outro mar. Assim, resolvemos carregar com o navio por sobre a copa das árvores - que era cerrada - e atravessar até ao outro mar, se fôssemos capazes. E assim fizemos. Amarrámos o barco a um grande cabo, depois subimos às árvores, e daí içámo-lo, a custo; depois pusemo-lo sobre as ramagens, desfraldámos as velas como se navegássemos num mar, e deste modo íamos avançando, com o vento de cauda. Aí veio-me à lembrança o verso do poeta Antímaco, que diz algures:

\section{Por bosques navegando prosseguiam.}

43. Forçada a floresta, lá chegámos à água; e novamente, pelo mesmo processo, pousámos o navio e começámos a navegar por uma água límpida e transparente, até que chegámos a um enorme precipício formado pela própria água, a qual se separava, como as fendas que muitas vezes vemos formarem-se na terra, devido a sismos. E, apesar de arriarmos as velas, não era fácil imobilizar o navio, e por pouco que este não foi arrastado. Debruçando-nos, vimos um abismo com cerca de $1000^{264}$ estádios de fundo, algo de absolutamente pavoroso e extraordinário: de facto, a água estava como que cortada a pique. Entáo, olhando à nossa volta, vimos, à direita e náo muito longe, uma ponte formada

\footnotetext{
262 c. $90 \mathrm{~km}$.

263 c. $9 \mathrm{~km}$.

264 c. $180 \mathrm{~km}$.
} 
de água, que ligava os dois mares à superfície e corria dum mar para o outro. Avançando, pois, à força de remos, lancámo-nos para essa parte e, depois de muita labuta e quando já náo tínhamos esperança, conseguimos passar para o outro lado.

44. Aí esperava-nos um mar calmo e uma ilha não muito grande, de acesso fácil e habitada; povoavam-na gentes selvagens, os Cabeças-de-Boi ${ }^{265}$, que tinham cornos, como entre nós se representa o Minotauro. Tendo desembarcado, embrenhámo-nos na ilha, a fim de nos abastecermos de água e arranjarmos alimentos, se pudéssemos. De facto, já não tínhamos provisões. No respeitante a água, achámo-la ali perto, mas, quanto ao resto, não aparecia nada; no entanto, ouvia-se, não longe dali, um mugido prolongado. Cuidando tratar-se duma manada de bois, avançámos com precaução, até que demos com os tais homens, os quais, ao verem-nos, nos perseguiram, tendo até capturado três dos nossos companheiros, enquanto eu e os restantes fugimos para o lado do mar. Em seguida, porém, tendo-nos armado todos (realmente, não achámos bem deixar sem vingança os nossos amigos), caímos sobre os Cabeças-de-Boi, que nessa altura estavam a dividir a carne dos prisioneiros mortos. Pusemo-los em debandada e perseguimo-los, tendo matado para aí uns cinquenta e apanhado vivos dois deles, após o que regressámos, trazendo esses connosco como reféns. Todavia, de comida é que não achámos nada. Foi então que alguns companheiros aconselharam a que matássemos os prisioneiros, mas eu não achei bem, pelo que os mandei amarrar, com guarda à vista, até que da parte dos Cabeças-de-Boi chegassem embaixadores a reclamar os prisioneiros, mediante resgate. De facto, compreendemos os seus gestos, bem como os mugidos de dor, como se estivessem a suplicar. $\mathrm{O}$ resgate consistiu em grande quantidade de queijos, peixe seco, cebolas e quatro veados, cada um dos quais possuía três patas: duas atrás, enquanto as da frente se uniam numa única. Tendo, pois, trocado por isto os prisioneiros, ainda ficámos mais um dia, após o que partimos.

45. Em breve começámos a ver uns peixes, umas aves a esvoaçarem, enfim, manifestavam-se todos os sinais de terra próxima. Pouco depois, vimos uns homens que navegavam duma forma

${ }^{265}$ Bouképhaloi, Bucéfalos. 
insólita: de facto, eles próprios eram [simultaneamente] marinheiros e navios. Vou contar a maneira como navegavam: deitados de costas sobre a superfície das águas, e com os pénis erectos - que eram realmente avantajados -, amarram-lhes as velas e, segurando com as mãos a bolina, navegam levados pelo vento. A seguir a estes, vimos outros, montados em pranchas de cortiça, às quais estavam atrelados dois golfinhos, que eles dirigiam por meio de rédeas. Os golfinhos, avançando, puxavam as cortiças. Estes homens náo nos fizeram mal nem fugiam de nós, mas antes passavam sem medo e com ar pacífico, admirando a forma do nosso barco e remirando-o de todos os ângulos.

46. Já ao cair da noite, aportámos a uma ilha muito grande, habitada por mulheres (era o que nós julgávamos), as quais falavam a língua grega. Vieram ao nosso encontro, saudaram-nos e abraçaram-nos; estavam ataviadas bem à moda das meretrizes, sendo todas formosas e jovens, e vestidas com túnicas que chegavam aos pés. Quanto à ilha, chamava-se Cobalussa $^{266}$, e a sua capital era Hidamárgia ${ }^{267}$. Ora, tendo escolhido os seus pares, cada uma levou o seu para sua casa e tratou-o como hóspede. Quanto a mim, tendo-me afastado um pouco - não adivinhava coisa boa -, eis que, olhando com mais cuidado, vejo ossadas de muitos homens e caveiras espalhadas. Não achei conveniente lançar o alarme, reunir os companheiros e pegar em armas, mas antes puxei da minha malva $^{268}$ e supliquei-lhe encarecidamente que me livrasse do perigo iminente. Pouco depois, enquanto a minha hospedeira me servia, reparei que não tinha pernas de mulher, mas sim cascos de burro. Então, saquei da espada, lancei-me sobre a mulher, amarrei-a e interroguei-a sobre todo aquele caso. E ela, embora contrafeita, acabou, no entanto, por falar, dizendo que eram mulheres marinhas chamadas Patas-de-Burro ${ }^{269}$, e que se alimentavam dos estrangeiros que por ali passavam. "Após os termos embriagado - disse - deitamo-nos com eles e, enquanto dormem, matamo-los.» Ao ouvir isto, deixei-a amarrada onde

${ }^{266}$ Kobaloussa, texto inseguro, talvez de kóbalos, "enganador», «embusteiro".

${ }^{267}$ Hydamargía, Texto ainda mais obscuro. Outros lêem Hydramardía.

268 V. $\$ 28$.

${ }^{269}$ Onoskeleis, Onósceles. 
estava, subi ao telhado e comecei a bradar, a fim de reunir os meus companheiros. Assim que eles chegaram, contei-lhes tudo, mostrei-lhes as ossadas e conduzi-os para dentro da casa onde estava a mulher amarrada. Esta, porém, de repente, transformou-se em água e desapareceu; mesmo assim, espetei a minha espada na água, a ver o que acontecia: e a água transformou-se em sangue.

47. Tendo então regressado a toda a pressa ao nosso navio, partimos imediatamente. E quando o dia despontou, avistámos terra, que cuidámos ser a que fica do lado oposto à habitada por nós. Prostrámo-nos, fizemos uma prece e começámos a fazer planos para o futuro: uns eram de parecer que somente devíamos desembarcar e voltar de novo para trás, enquanto outros eram a favor de deixar ali o barco e penetrar no continente, a ver os seus habitantes. Enquanto discutíamos o assunto, eis que caiu sobre nós uma violenta tempestade, que atirou o barco para a praia e o despedaçou. A muito custo, conseguimos salvar-nos a nado, tendo cada um tomado as suas armas e tudo o mais que pôde.

Esta é a minha história sobre o que me aconteceu até chegarmos à outra terra: no mar, durante a navegação nas ilhas, no ar, depois dentro da baleia, e quando dela saímos, na ilha dos Bem-Aventurados e na dos Sonhos, e por fim na terra dos Cabeças-de-Boi e na das Pés-de-Burro.

Quanto às aventuras nesta terra, contá-las-ei nos livros seguintes ${ }^{270}$.

${ }^{270}$ É praticamente certo que Luciano não chegou a escrever a sequência das suas "aventuras». Provavelmente, devemos aplicar, também a estas promessas, as palavras do $₫ 4$ : não são para acreditar... 
O MENTIROSO OU O INCRÉDULO 
(Página deixada propositadamente em branco) 


\section{O MENTIROSO OU O INCRÉDULO}

\section{INTRODUÇẤO}

Luciano tem uma visão extremamente crítica da sociedade do seu tempo, dominada pelo irracional, que impregnava não só as grandes massas populares (variadas religióes de mistério e salvação, crendice nas práticas de magia, superstições pueris, etc.), mas até o mundo intelectual, quando este ultrapassava o idealismo estritamente filosófico em que deveria confinar-se. Realmente, muitos desses homens - afamados filósofos e mestres de filosofia - deixaram-se conquistar por uma metafísica que já náo era filosófica, mas sim irracionalismo de tipo popular.

Com mais de meio milénio de Filosofia, a Grécia vira nascer, desenvolver-se e evoluir uma grande variedade de correntes de pensamento, que na época de Luciano se tornaram exclusivistas, dogmáticas e intolerantes: pitagóricos, académicos (platónicos), peripatéticos (aristotélicos), cínicos, estóicos, epicuristas, etc., digladiavam-se violentamente. De todas as escolas, Luciano só poupa os epicuristas, precisamente por estes tentarem manter uma atitude racional. O passo $(\$ 32)$ em que Tiquíades se refere a Demócrito (juntamente com Leucipo, o inspirador da vertente científica do epicurismo) é bem significativo da admiração que Luciano tinha por estes homens, apetrechados dum forte espírito crítico, a que Luciano adere.

A este respeito, convirá mencionar, mais uma vez, entre outras obras, o Hermotimo, que é talvez o mais violento libelo alguma vez lançado contra todas as correntes idealistas no seu conjunto. Para sermos exactos, Luciano náo condena, propriamente, as diversas escolas filosóficas, mas sim o seu exclusivismo, o seu dogmatismo, a sua intolerância e, muito especialmente, a distância que vai dos princípios morais apregoados à prática real dos grandes mestres.

Se, no que respeita à filosofia, Luciano aceita e compreende as diversas doutrinas em si mesmas e revela admiração pelo epicurismo, já no tocante à religião e, sobretudo, à mitologia tradicional, a crítica é global: não nega (pelo menos explicitamente) a existência dos velhos deuses, semideuses e heróis da Grécia. Entende-os, no entanto, e principalmente, como elementos culturais inerentes à organização social e necessários 
à literatura e às artes. Só não aceita o carácter «literal» de toda uma mitologia fantástica, pueril e, tantas vezes, imoral.

Mas, se a mitologia lhe causa reacçóes de pura irritação, ainda mais alérgico se revela relativamente às religióes de mistério e salvação, cujos sacerdotes enganam as multidóes por processos grosseiros que uma crítica fria e acerada não tem dificuldade em desmascarar. Uma das obras mais significativas neste aspecto é a intitulada Alexandre ou o Falso Profeta, que é a biografia vergonhosa dum sacerdote que recorre a truques baixos e ilusionismos ou simples viciação, para se impor como enviado da Divindade.

Um outro aspecto contra o qual se revolta o espírito crítico de Luciano é o do irracionalismo dos grandes filósofos e mestres de filosofia do seu tempo, que acreditam nas artes mágicas, nas curas milagrosas, em fantasmas, espíritos e demónios. É certo que Luciano também escreveu alguns livros de ficção, como, por exemplo, O Burro. Trata-se, porém, de mentiras assumidas, com a finalidade de divertir e distender o espírito (sempre, é claro, com alguma crítica à mistura). Nesta ordem de ideias, aceita, e ele próprio pratica, a fantasia inócua. $\mathrm{O}$ que não admite é que certas pessoas com responsabilidade na educação da juventude se deixem possuir desse misticismo levado ao mais alto grau do irracional e tentem transmiti-lo aos outros como verdade absoluta e irrefutável.

Tal é o tema do opúsculo $O$ Mentiroso, no qual Tiquíades (que obviamente representa Luciano) relata ao seu amigo Fílocles as histórias incríveis de curas milagrosas, exorcismos, demónios e fantasmas, encantamentos amorosos, apariçôes infernais, metamorfoses, levitação, etc., que ouvira contar em casa de Eucrates, onde se havia reunido a fina flor da intelectualidade mais representativa das escolas filosóficas. Só não estava presente um epicurista... a não ser, talvez, Tiquíades: pelo menos é ele o único que tenta contrariar, um por um e com argumentação racional, todo aquele chorrilho de mentiras. Mas a tarefa é difícil, pois, para além de ser um só contra muitos, acontece que é ingrato e incómodo discutir "fenómenos» apresentados como reais, vistos e testemunhados pelos próprios narradores e corroboráveis (mesmo corroborados) por testemunhas «oculares» de confiança... dos narradores. Neste ponto, chamamos a atenção para os processos típicos da «linguagem da verdade», sabiamente utilizados pelos mentirosos de todos os tempos. Ao 
fim de algum tempo, Tiquíades só vê uma solução: partir a toda a pressa, embora (apesar de tudo...) com uma desculpa de pessoa educada: "Bem, vou-me embora, vou procurar Leôntico, pois tenho necessidade de tratar dum assunto com ele. Quanto a vós, que não julgais já bastantes as coisas humanas, invocai os deuses para que vos ajudem nas vossas histórias prodigiosas.

O Mentiroso constitui um documento, ou um documentário, de crítica a uma classe intelectual decadente, com uma erudição geral que abarca mais de meio século de filosofia e quase um milénio de literatura. São homens dogmaticamente especializados numa corrente filosófica, mas a quem este acúmulo de conhecimentos não deu o suficiente espírito crítico que os afastasse de práticas, crenças, crendices e superstiçōes do tipo mais vincadamente popular. Até nisso (ou sobretudo nisso...) $O$ Mentiroso é uma obra actual.

À pergunta de Tiquíades - Por que motivo agem desse modo? - Fílocles só encontra uma resposta (\$2): «Ora... que outro motivo haverá, senão uma aberração de espirito, para que não falem verdade e prefiram o péssimo ao óptimo?»

Contra esta aberração de espírito, existe um único antídoto (final do diálogo): "a verdade e o justo espirito critico. Se soubermos usar dele, nenhuma dessas balelas vazias e vãs nos perturbará."

Nota à tradução: Segui o texto fixado por Karl MRAS, Die Hauptwerke des Lukian, Ernst Heimeran, Freising, 1954.

Este livro, como outros da Antiguidade, era conhecido com

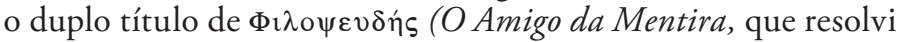
simplificar: $O$ Mentiroso) e 'A $\pi \iota \tau \tau \hat{\omega} v$ (O Incrédulo). Ambos poderáo considerar-se de acordo com o conteúdo da obra, conforme o ponto de vista em que nos coloquemos. De facto, referido a Tiquíades - a personagem que mantém sempre a atitude de incredulidade em relação aos contadores de histórias fantásticas -, assenta-lhe bem o título de $O$ Incrédulo; mas também não fica nada mal referido aos contadores de mentiras. 
(Página deixada propositadamente em branco) 


\section{O MENTIROSO OU O INCRÉDULO}

1. TIQUíADES - És capaz de me dizer, Fílocles, que é que leva a maior parte das pessoas a gostar da mentira, a ponto de se comprazerem em dizer coisas absolutamente disparatadas e prestarem atenção a quem as conta?

FílOCLES - Ora, Tiquíades, há muitos motivos que induzem as pessoas a mentir, quando pretendem com isso obter um benefício.

TIQUÍADES - Isso não vem ao caso, como sói dizer-se. Eu não me refiro àquelas pessoas que mentem em proveito próprio: essas, ao menos, têm desculpa, e algumas são mesmo dignas de louvor, quando enganam os seus inimigos ou, num aperto, se servem desse remédio para se livrarem de problemas, como tantas vezes fez Ulisses, ao tentar salvar a sua própria vida e assegurar o regresso dos companheiros. Eu falo é daquelas, meu caro amigo, que, sem precisão nenhuma disso, preferem a mentira à verdade e se comprazem e entretêm com ela, sem qualquer pretexto premente. Pretendo, portanto, saber por que motivo agem desse modo.

2. FílOCLES - Tens, por acaso, conhecimento de pessoas dessas, com um tal pendor ingénito para a mentira?

TIQUÍADES - Mas com certeza... e muitas.

FÍLOCLES - Ora... que outro motivo haverá, senão uma aberração de espírito, para que não falem verdade e prefiram o péssimo ao óptimo?

TIQUÍADES - Nada disso, pois eu poderia apontar-te muitas pessoas, sensatas quanto ao resto e dotadas de admirável discernimento, mas que, não sei porquê, se deixam agarrar por este vício e gostam de mentir. Aflige-me ver tais homens, em tudo o mais eminentes, mas que se comprazem em se enganarem a si mesmos e ao próximo. Sabes melhor do que eu que os antigos, [por exemplo] Heródoto e Ctésias de Cnido, e, antes destes, os poetas e o próprio Homero (tudo homens ilustres) lançaram máo da mentira por escrito, e de tal modo, que não só enganavam os ouvintes desse tempo, mas a mentira chegou até aos nossos dias, trazida por uma tradiçáo conservada em prosa e versos admiráveis. Muitas vezes, chego a sentir vergonha por esses homens, quando [por exemplo] narram a mutilação de Úrano ${ }^{271}$, ou o agrilhoamento de Prometeu, ou a

${ }^{271}$ Decidi ser parco em anotaçôes, especialmente se as alusôes mitológicas já são suficientemente explícitas, como neste e noutros casos. 
revolta dos Gigantes, ou toda a tragédia de $\mathrm{Hades}^{272}$, ou como Zeus, por amor, se transformou em touro ou em cisne, ou como uma mulher foi metamorfoseada em ave ou em urso, ou quando falam de Pégasos, Quimeras, Górgonas, Ciclopes ${ }^{273}$ e outras coisas que tais - fabuletas bem bizarras, próprias para encantar os espíritos dos meninos que ainda têm medo de Mormo e de Lâmia ${ }^{274}$.

3. Apesar de tudo, as ficçóes dos poetas talvez ainda sejam toleráveis. Mas que cidades e povos inteiros digam tantas mentiras, em conjunto e descaradamente, náo é coisa para rir? Os Cretenses não sentem vergonha de mostrar o túmulo de Zeus; os Atenienses afirmam que Erictónio brotou da terra e que os primeiros homens germinaram do solo da Ática, como se fossem hortaliças. Estes, no entanto, têm uma origem mais respeitável que a dos Tebanos, que contam que dos dentes duma serpente nasceram uns tais $S p a r t o i^{275}$. E no entanto, todo aquele que não considere verdadeiras essas histórias ridículas, mas, pelo contrário, submetendo-as a uma análise conscienciosa, considere como próprio dum Corebo ou dum Margites ${ }^{276}$ acreditar que Triptólemo atravessou os ares montado em dragóes alados, ou que Pan veio lá da Arcádia aliar-se aos guerreiros de Maratona, ou que Oritia foi raptada por Bóreas, esse seria considerado ímpio e insensato, por não acreditar em factos tão evidentes e verdadeiros. Tal é o poder da mentira!

4. FÍlOCLES - Mas... ó Tiquíades, os poetas e as cidades ainda teriam desculpa: aqueles, ao misturarem nos seus escritos o encanto arrebatador do mito, de que necessitam para cativar os seus ouvintes; e quanto aos Atenienses, Tebanos e outros, ao pretenderem, com tais histórias, nobilitar ainda mais as respectivas pátrias. Ora, se privássemos a Grécia das suas lendas, nada obstaria a que os guias [turísticos] morressem de fome, por falta de visitantes estrangeiros

${ }^{272}$ Deveria antes dizer-se "a tragédia [do reino de] Hades». Hades é outro nome de Plutão, rei dos Infernos.

${ }^{273} \mathrm{O}$ autor, por ironia, póe tudo no plural, mas Pégaso e Quimera eram personagens individuais, únicas, enquanto as Górgonas eram três, e os Ciclopes mais que muitos.

${ }^{274}$ Personagens femininas, eram os «papôes» mais temidos pelos meninos.

275 A palavra significa «semeados».

276 Corebo e, sobretudo, Margites eram símbolos por excelência da cretinice, da credulidade e do convencimento ridículo dos méritos próprios. 
que, mesmo sem pagarem, quisessem escutar a verdade. Tais guias, unicamente pelo facto de náo condescenderem com a mentira, seriam, provavelmente, postos a ridículo.

5. TIQUíADES - Dizes bem. A propósito, acabo de chegar de casa de Êcrates, onde ouvi tantas histórias incríveis e fabulosas, que, não suportando tanto exagero, deixei-o a contar essas monstruosidades e bizarrices, retirando-me a toda a velocidade, como se as Erínias viessem a correr atrás de mim.

FÍlOCLES - E no entanto, ó Tiquíades, Êucrates é pessoa digna de fé: ninguém iria cuidar que ele, com aquela longa barba e homem já de sessenta anos, e, para mais, todo dado à filosofia, tolerasse que, fosse quem fosse, mentisse na sua frente, quanto mais ousar ele próprio fazê-lo.

TIQUÍADES - E que tu não sabes, companheiro, que enormidade de coisas ele disse, como afiançava a sua autenticidade, como jurava (quase sempre pela felicidade dos filhos)... a tal ponto que, ao vê-lo assim, desencontrados pensamentos me ocorreram: ou que estaria doido e fora do seu estado normal, ou que talvez fosse, afinal, um charlatão, que, durante todos estes anos, escondera, sob a pele de leáo, o macaco que realmente era. A tal ponto absurdas eram as suas histórias!

FÍLOCLES - Mas que histórias eram essas, ó Tiquíades? Por Vesta! Sim, quero saber que imposturice ele dissimulava por debaixo duma barba táo imponente.

6. TIQUÍADES - Ora bem, Fílocles: eu tenho por hábito ir de vez em quando visitá-lo, sempre que tenho vagar. Hoje, porém, precisando de me encontrar com Leôntico (que, como sabes, é meu íntimo amigo), fui informado pelo seu criado de que o amo tinha ido fazer uma visita a Êucrates, que estava doente. Por estes dois motivos - a fim de me encontrar com Leôntico e para visitar Êucrates, pois não sabia que se encontrava doente -, dirijo-me a casa deste. Já lá não encontrei Leôntico (que, segundo me disseram, tinha acabado de sair), mas um grande número de pessoas, entre as quais estavam o peripatético Cleodemo, o estóico Dinómaco e Íon (que tu bem conheces: é um tipo que, quando se trata das obras de Platão, reivindica a honra de ser admirado como a única pessoa que entende perfeitamente o pensamento do filósofo e a única capaz de explicá-lo aos outros). Já estás a ver a que grandes personalidades 
me refiro?! Tudo gente sapientíssima, virtuosíssima, a fina flor de cada escola filosófica, todos veneráveis e de aspecto pouco menos que aterrador. Estava também presente o médico Antígono, chamado, creio eu, por causa da doença de Êcrates. Este parecia já estar melhor, e a doença agora era a do costume. De facto, o fluxo dos humores havia novamente descido para os pés. Então Êucrates convidou-me a sentar-me a seu lado no leito, baixando a voz até ao tom de doente, muito embora eu, ao entrar, o tivesse ouvido esganiçar-se todo. Com toda a cautela para não lhe tocar nos pés (e depois de me ter justificado, como é costume, por náo ter tido antes conhecimento de que ele estava doente, mas dizendo que, mal fui disso informado, vim logo a correr), sentei-me a seu lado.

7. As visitas já antes haviam falado sobre a doença, e ainda estavam a dissertar, cada um a sugerir o seu tratamento.

E diz Cleodemo:

Portanto, se apanharmos do chão, com a mão esquerda, um dente de doninha morta conforme antes disse, se depois o envolvermos numa pele de leão acabado de esfolar e a atarmos à volta das pernas [do doente], a dor cessa imediatamente.

E diz Dinómaco:

Numa pele de leão, não, segundo ouvi dizer, mas sim numa pele de corça virgem e que ainda não teve cio. Desta maneira, a coisa é mais verosimil. De facto, a corça é um animal muito veloz, que tem a sua força principal nas patas. O leão é forte, sim senhor, e a sua gordura, bem como a pata direita e os pêlos eriçados da crina, poderão prestar grandes serviços, desde que saibamos utilizar cada uma dessas partes acompanhada da fórmula mágica apropriada. No entanto, serve de muito pouco na cura de pés.

E diz Cleodemo:

Também eu dantes cuidava que se devia utilizar uma pele de corça, uma vez que a corça é um animal veloz. No entanto, ainda há pouco tempo, um homem libio, conhecedor dessas matérias, fez-me mudar de opiniāo, dizendo-me que os leöes são mais velozes que as corças, o que está fora de dúvida - afirmou-, pois eles perseguem-nas e apanham-nas.

Os presentes elogiaram o líbio como tendo falado muito bem. 
8. Aí disse eu: E vós acreditais que esses males cessam por meio de fórmulas mágicas ou com aplicaçóes externas à doença que se desenvolve no interior?

Puseram-se todos a rir das minhas palavras, sendo manifesto que me acusavam de grande ignorância, por não saber coisas tão óbvias e que ninguém de bom senso ousaria contradizer, dizendo que não é assim. Todavia, o médico Antígono parecia congratular-se com a minha pergunta. De facto, já desde há muito tempo, julgo eu, que ele era posto de lado ao pretender ajudar Êcrates por meio da sua arte, prescrevendo-lhe que se abstivesse de vinho, comesse legumes e, sobretudo, que relaxasse a tensão. Vai daí, diz Cleodemo, sorrindo:

Que dizes a isto, Tiquiades? Parece-te inacreditável que se tire benefício deste tipo de remédios para as doenças?

Parece, pois - respondi -... a menos que eu esteja tão apanhado por uma gripe ruim ${ }^{277}$, que acredite que remédios externos, sem comunicação alguma com as causas das doenças, actuem quando acompanhados de palavras ou, como vós dizeis, de certas fórmulas encantatórias, e que esses remédios, quando em contacto com a zona doente, induzem a cura. Tal não seria possivel, mesmo que atásseis dezasseis doninhas inteiras à pele do leão de Nemeia. Eu mesmo já vi muitas vezes o próprio leão coxear com dores, mesmo completamente envolvido na sua própria pele.

9. És muito ignorante - comentou Dinómaco -, por não teres tido o cuidado de aprender estes remédios, bem como a maneira de tirar proveito deles, aplicando-os em caso de doença. Também não me parece que admitas estes factos evidentissimos, como a expulsão das febres periódicas, o encantamento de serpentes, a cura de tumores inguinais e todas as demais maravilhas que as velhas ainda hoje operam. Ora, se tudo isso se faz, porque é que não crês que estas curas se realizam por métodos semelhantes?

Ó Dinómaco - retorqui -, estás a tirar conclusóes inadequadas, ou, como sói dizer-se, "estás a tirar um prego com outro prego". Realmente, não está provado que essas curas que tu referes aconteçam por obra de tais poderes. Portanto, se antes, por um processo de indução racional, não me convenceres de que esses factos ocorrem segundo a ordem natural (isto é, que a febre e o edema têm medo quer dum nome divino, quer duma palavra bárbara,

${ }^{277} \mathrm{O}$ texto diz: "... que tenha o nariz tão cheio de gripe...". Trata-se duma gripe ruim, daquelas que afectam o estado mental da pessoa. 
e que é devido a isso que o tumor inguinal abandona o corpo), considero as vossas palavras como fábulas de velhas.

10. Tenho a impressão - disse Dinómaco - de que, ao falares desse modo, não crês na existência dos deuses, já que não acreditas em curas operadas por palavras santas.

Não digas isso-respondi eu-. Realmente, nada impede que os deuses existam, mas que esses milagres sejam falsos. Por mim, respeito os deuses e reconheço as curas que eles operam, tal como o bem que eles fazem aos doentes, restabelecendo-os por acção de medicamentos e da medicina. De facto, o próprio Esculápio e os seus filhos curavam os doentes aplicando-lhes remédios suaves, $e$ não ligando-lhes à volta do corpo [coisas de] leóes ou doninhas.

11. Deixa lá - interrompeu Íon -, que eu vou contar-vos um acontecimento maravilhoso. Era eu ainda rapaz, andava ai pelos catorze anos, quando [um dia] vieram anunciar a meu pai que Midas, o seu vinhateiro (aliás um criado forte e trabalhador), tinha sido mordido por uma vibora, ai por volta do meio-dia, e jazia por terra com a perna já a gangrenar. Fora o caso que, estando ele a atar os sarmentos das videiras e a entrelaçá-los nas estacas, o bicho rastejou direito a ele e mordeu-lhe o dedo grande [do pé], indo logo enfiar-se na toca. Ainda a notícia corria, quando vimos o dito Midas a ser transportado numa maca pelos seus companheiros, todo inchado, livido, a apodrecer, mas ainda com uma leve respiração superficial. Impressionado com o desgosto de meu pai, um dos amigos presente disse: "Anima-te, que eu vou já procurar um babilónio, um desses homens a que chamam caldeus, e ele vai curar-te o rapaz". Para náo me alongar mais, chegou o babilónio, que restabeleceu Midas por meio duma fórmula mágica, expulsando-lhe o veneno do corpo e pendurando-lhe no pé uma pedra arrancada da coluna funerária duma donzela acabada de morrer. Talvez isto não seja nada de especial, mas o que é certo é que Midas pegou na maca em que tinha sido transportado e foi a caminho da propriedade. Tal foi o poder daquela fórmula mágica e daquela pedra sepulcral!

12. O babilónio [-continuou Íon-] operou ainda outros prodigios verdadeiramente divinos. Efectivamente, dirigiu-se à propriedade e, tendo pronunciado sete palavras sagradas tiradas dum velho livro, purificou o lugar com enxofre e um facho, 
percorrendo-o por três vezes, com o que expulsou todos os répteis que se encontravam dentro da zona: como que atraidos pela fórmula mágica, vimos chegar muitas serpentes, áspides, víboras, cerastas, cobras, sapos e relas. Mas faltava um velho dragão, que, julgo eu, devido à idade, não fora capaz de se arrastar para fora do buraco, deixando de obedecer à ordem. Então o mago disse que não estavam ali todos, pelo que, designando com um gesto uma das serpentes mais novas, enviou-a como seu embaixador junto do dragáo. Passado pouco tempo, este apresentou-se. Uma vez reunidos, o babilónio soprou sobre eles, ficando todos estorricados com o bafo, enquanto nós nos maravilhávamos.

13. Diz-me cá, Íon - perguntei eu -: essa jovem serpente embaixadora trazia o dragáo pela mão (pois, segundo afirmas, era já muito velho), ou ele vinha arrimado a um cajado?

Estás a galhofar - disse Cleodemo -. Também eu, dantes, era mais incrédulo que tu: não admitia, de modo nenhum, que se pudesse dar crédito a tais prodigios. Quando, porém, vi pela primeira vez elevar-se nos ares um estrangeiro, um bárbaro (hiperbóreo ${ }^{278}$, segundo ele próprio afirmava), eu, que havia resistido muito tempo, dei-me por vencido e passei a acreditar. Sim, que outra coisa podia fazer, ao vê-lo, em pleno dia, deslocar-se pelos ares, andar sobre as águas e atravessar o fogo com todo o vagar, a passo?

Mas tu - perguntei eu - viste mesmo o hiperbóreo a voar ou a caminhar sobre a água?

Com certeza - respondeu -... ele até trazia calçadas umas botas de couro do tipo daquelas que eles lá usam. Mas isto ainda não é nada. Que dizer de quantas outras maravilhas que ele nos fez ver, como insuflar paixöes, invocar espiritos, ressuscitar mortos já putrefactos, fazer aparecer Hécate ${ }^{279}$ em pessoa e atrair a Lua cá abaixo à Terra!

14. [E continuou:] Pois vou contar-vos o que vi o babilónio fazer em casa de Gláucias, filho de Aléxicles. Este Gláucias, que há pouco tinha recebido a herança por morte do pai, apaixonou-se por Criside, filha de Démeas. Nessa época, eu era professor de filosofia do jovem. Se aquela paixão não se tivesse apoderado dele, a esta hora já saberia toda a doutrina peripatética, pois, com dezoito

${ }^{278}$ Hiperbóreo, i. é, "para além do Bóreas" (ou Norte): um nórdico.

${ }^{279}$ Deusa do mundo subterrâneo. 
anos, já dominava a técnica da análise e tinha seguido até ao fim o curso de Física. Ora, sentindo dificuldade de realizar a sua paixão, vem ter comigo e conta-me tudo. E eu, como era natural na minha qualidade de seu professor, mando vir junto dele o tal mago hiperbóreo, mediante quatro minas ${ }^{280}$ pagas imediatamente (era preciso fazer um adiantamento para os sacrifícios), mais dezasseis, se acaso obtivesse os favores de Críside. Então o mago, esperando a fase da lua cheia (que é quando os encantamentos deste género dão mais resultado), abriu uma cova no pátio da casa e, à meia-noite, começou por invocar Aléxicles, pai de Gláucias, já falecido havia sete meses. Ao principio, o velho irritou-se, todo furioso com aquela paixão do filho, mas, por fim, consentiu nesse amor. Em seguida, o mago fez aparecer Hécate acompanhada de Cérbero ${ }^{281}$; depois forçou a Lua a descer-espectáculo multiforme, em que nos aparecia ora uma coisa, ora outra: primeiro, surgiu uma figura de mulher, depois um boi magnifico, a seguir apareceu um cão. Por fim, modelou em barro uma figurinha de Eros e disse-lhe: "Vai e traz Criside!". Imediatamente o barro voou dali para fora e, passado pouco tempo, veio a tal rapariga, que bateu à porta, entrou e se lançou nos braços de Gláucias, loucamente apaixonada. E com ele dormiu até ao cantar dos galos. Então a Lua subiu de novo ao céu. Hécate desceu às profundezas da terra, as outras visóes desvaneceram-se, e nós, mesmo ao romper da alvorada, levámos Críside a casa.

15. [E concluiu:] Se tivesses assistido a este espectáculo, Tiquiades, já não duvidarias de que as fórmulas mágicas têm grande utilidade.

Dizes bem - observei -: realmente, eu acreditaria, se tivesse assistido. Mas, para já, peço desculpa por não ser capaz de ver com essa vossa finura. No entanto, eu conheço essa tal Críside de que falais: é uma mulher muito dada aos amores e bastante abordável. Náo vejo que necessidade tivestes de empregar com ela um embaixador de barro, um mago hiperbóreo e a própria Lua, quando, apenas por vinte dracmas, poderieis mesmo levá-la até

${ }^{280}$ A mina correspondia a 100 dracmas. O pagamento (adiantado) de 4 minas era um preço náo muito baixo. As 20 minas a pagar na totalidade já representavam uma boa quantia.

${ }^{281}$ Cérbero é o cão que guarda o reino de Plutão, os Infernos. Na versão mais corrente, é um animal tricéfalo, mas há variantes: 50 cabeças; uma só cabeça de cáo e muitas cabeças de serpente pelo corpo; 3 cabeças de cão, das quais saem cabeças de serpente; etc. 
ao próprio pais dos Hiperbóreos. De facto, essa mulher sente uma grande atracção por um encantamento deste género, procedendo até ao contrário dos fantasmas: estes, quando ouvem o tilintar do bronze ou do ferro, fogem (é o que vós afirmais); ela, pelo contrário, mal ouve o tilintar do dinheiro ${ }^{282}$, acorre a este som. Aliás, também admiro esse tal mago, porquanto, podendo ele próprio fazer-se amar pelas mulheres mais ricas e receber delas talentos e mais talentos ${ }^{283}$, se limita, o mesquinho, a tornar Gláucias amado só pelo preço de quatro minas.

16. Fazes uma figura ridicula - disse Íon -, ao pores tudo em dúvida. Mas agora gostaria de te perguntar o que é que pensas daqueles individuos que libertam os endemoninhados dos seus terrores e que tão radicalmente exorcizam os fantasmas. Nem preciso de procurar muito: toda a gente conhece o sirio da Palestina, especialista nesta matéria, o qual, ao topar no seu caminho, na fase da lua cheia, com pessoas prostradas no chão, com os olhos fora das órbitas e deitando espuma pela boca ${ }^{284}$, as póe em estado de andar e as manda à sua vida, já recompostas, depois de cobrar uma avultada quantia por as ter livrado do mal. Ao chegar junto duma pessoa prostrada, pergunta-lhe como é que os demónios the entraram no corpo. $O$ doente fica calado, quem responde é o demónio (em grego ou numa lingua bárbara, conforme a sua proveniência), dizendo como entrou na pessoa e donde é que veio. Então o mago esconjura-o, e, se ele não obedece, ameaça-o, até conseguir expulsar o demónio. Eu mesmo vi alguns a sair, negros e de pele cor de fumo.

Não é nada de espantar - comentei eu - que tu, Ion, vejas coisas como essa, já que consegues ver as Ideias de que fala Platão, vosso pai, mas cuja visáo é muito obscura para nós, gente de vista fraca.

17. Mas será que Íon - disse Êucrates - foi o único que viu tais coisas? Muitas outras pessoas não têm também topado com espiritos, umas de noite e outras de dia? Pela minha parte, não foi só uma vez, mas dez mil, que eu assisti a factos destes. Ao princípio, ficava apavorado, mas agora, pela força do hábito, já não me parece ver nada de extraordinário, especialmente desde que

282 argýrion significa "prata" e "dinheiro", como fr. argent.

${ }^{283} \mathrm{O}$ talento de prata equivale a $6000 \mathrm{dracmas}$, mas, propriamente, é aquilo a que se chama "unidade de conto", cf. port. "contos de réis».

${ }^{284}$ Trata-se da epilepsia. 
um árabe me deu um anel fabricado com ferro tirado das cruzes [do suplicio] e me ensinou uma fórmula mágica constituida por muitas palavras... a menos que não acredites em mim, Tiquiades...

Ao que eu respondi: Mas como não acreditar em Eucrates, filho de Dinon, homem sábio, que, em sua casa e com toda a autoridade, diz com toda a franqueza o que muito bem lhe apetece?

18. Pois bem - continuou Êcrates -, podes ouvir, não apenas da minha boca, mas também da boca de todos os meus ${ }^{285}$, o fenómeno que se passa com uma estátua e que pode ser visto todas as noites por toda a gente cá de casa, jovens e velhos. Que estátua é essa? - perguntei eu.

Não tens visto - disse Êucrates -, ao entrares no pátio, uma estátua magnifica dum homem de pé, obra do estatuário Demétrio?

Referes-te porventura - perguntei - ao homem do disco, curvado na atitude de quem vai executar o lançamento, com a cara virada para o lado da máo que tem o disco, e que, flectindo levemente os joelhos para o lado contrário, parece mesmo ir erguer-se após o lançamento?

Não - respondeu Êucrates -, não é essa. Essa, o discóbolo a que te referes, é uma das obras de Miron. Nem é a estátua ao lado desta, a do belo jovem com uma faixa a envolver-lhe a cabeça, pois essa é obra de Policlito. Póe de lado as estátuas que estão à direita de quem entra, entre as quais se encontram os Tiranicidas, criaçóes de Crício e Nesiotes. Pois bem: já alguma vez reparaste, junto do repuxo, na estátua dum homem de ventre saliente, calvo, apenas semicoberto pelo manto, com alguns pêlos da barba agitados pelo vento, de veias bem marcadas, tal e qual um homem verdadeiro? É esse mesmo, Pélico de Corinto... um general, ao que parece.

19. Sim, por Zeus - disse eu -, já vi uma estátua assim, à direita da estátua de Cronos, com faixas e coroas secas e com o peito coberto de folhas doiradas.

Pois - disse Eucrates - fui eu que as mandei doirar, quando ele me curou, em três dias, duma febre crónica que me consumia.

Quer dizer - observei - que o bom do Pélico é também médico? $\hat{E}$, pois - respondeu Êcrates -, e vê lá não escarneças, ou náo tardará muito que o homem te castigue. Eu sei bem do que é capaz esta estátua de que tu estás a escarnecer. Ou não achas

285 «Todos os meus» envolve família e criados, cf. lat. familia. 
que ela também é capaz de enviar febres a quem ela quiser, já que pode expulsá-las?

Que essa estátua - disse eu -, já que é tão parecida com um homem, me seja propicia. Mas... que coisa é essa que todos vós ai em casa lhe vedes fazer?

Assim que anoitece - disse Êcrates -, salta do pedestal em que está assente e faz a ronda da casa. Todos nós deparamos com ela, que algumas vezes chega mesmo a cantar, mas nunca fez mal a ninguém: só é preciso afastarmo-nos do seu caminho, que ela continua a caminhar, sem molestar absolutamente ninguém que esteja a olhar para ela. Muitas vezes, vai tomar banho e fica a brincar com a água toda a noite, de tal modo que se ouve a água a marulhar.

Vê lá mas é - comentei eu - se a estátua representa, não Pélico, mas sim Talos de Creta, filho de Minos. É verdade que este era feito de bronze e era vigia de Creta. Em todo o caso, Eucrates, embora a tua estátua não seja de bronze, mas de madeira, nada obsta a que seja, não obra de Demétrio, mas uma das engenhosas invençôes de Dédalo, tanto mais que, segundo afirmas, ela salta do pedestal.

20. Vê lá bem, Tiquiades - ameaçou Êcrates -, não venhas a arrepender-te da tua zombaria... mas já tarde. Eu é que sei o que padeceu aquele fulano que roubou os óbolos que todas as luas novas nós the ofereciamos.

Deve ter sido um castigo terrivel - comentou Íon -, já que o tipo era um sacrílego. Mas... como é que a estátua se vingou, ó Eucrates? Sim, quero ouvir a história, por muito que aqui o Tiquiades vá certamente desacreditá-la.

Havia aos pés da estátua - disse Êucrates - uma grande quantidade de óbolos, bem como algumas outras moedas, de prata, coladas com cera na sua coxa, e ainda umas folhas de prata (votos dirigidos por alguém ou oferta de acção de graças por motivo de cura, deixada por pessoas que, por sua acção, se haviam visto livres duma febre que as atacara). Ora, havia em nossa casa um criado libio, mau tipo, que tratava dos cavalos. Este individuo resolveu furtar de noite tudo aquilo, e furtou mesmo, aguardando que a estátua já tivesse descido do seu pedestal. Quando Pélico regressou e viu que tinha sido roubado, pensou logo na forma de se vingar do libio e fazê-lo ser apanhado em flagrante. E assim foi: durante a noite, o desgraçado andou às voltas pelo pátio, sem ser capaz de sair, 
como se tivesse caido num labirinto, até que, ao amanhecer, foi apanhado na posse das moedas roubadas. Assim apanhado em flagrante, levou não pouca pancadaria. E tendo vivido ainda algum tempo, o miserável morreu miseravelmente, chicoteado todas as noites, segundo dizia, e com tal violência, que, no dia seguinte, eram visiveis as nódoas no corpo. Depois disto, Tiquiades, continua a zombar de Pélico e a tomar-me a mim por um velho dos tempos de Minos, um velho que começa a dizer disparates.

Mas... ó Êurates - disse eu -, "bronze é bronze" ${ }^{286}$ : a estátua é obra de Demétrio de Alópece, que não esculpe deuses, mas homens, pelo que não vou ter medo da estátua de Pélico, cujas ameaças nem em vida dele eu temeria um pouco que fosse.

21. Depois disto, interveio o médico Antígono: Eu possuo, Eucrates, um Hipócrates de bronze do tamanho de um côvado ${ }^{287}$. Sempre que o pavio da lamparina se apaga, começa a deambular por toda a casa, fazendo muito barulho, derrubando as caixas, misturando as drogas e batendo com a porta, especialmente se nos atrasamos no sacrifício que todos os anos oferecemos em sua honra.

Quer dizer - intervim eu - que o médico Hipócrates continua, ainda hoje, a exigir que lhe ofereçam sacrificios, e fica furioso, se, em seu devido tempo, não é presenteado com sacrifícios perfeitos??288 Ele havia de gostar que alguém lhe prestasse honras fúnebres ou the fizesse uma libação de mel e leite, ou lhe pusesse uma coroa na cabeça.

22. Agora escuta lá - interrompeu Êucrates - uma coisa que eu vi há cinco anos e que pode ser corroborada por testemunhas oculares. Estávamos na época das vindimas. Por volta do meio-dia, deixei os trabalhadores a vindimar na propriedade e dirigi-me sozinho para o bosque, meditando e reflectindo comigo mesmo. Estando eu na zona mais densa do bosque, eis que começo a ouvir latidos. Pensei que era o meu filho Mnáson que, como de costume, tivesse vindo brincar e caçar para a mata com os companheiros. Mas não era nada disso, pois, dai a pouco, produz-se um tremor de terra, ouve-se um estrondo como que de trováo, e vejo avançar para mim uma mulher de aspecto aterrador, com cerca de meio

${ }^{286}$ Dito proverbial que significa «o que é, é» ou "pão-pão, queijo-queijo».

287 Teoricamente, o côvado ("cotovelo») equivale a $66 \mathrm{~cm}$.

288 Para os Gregos, como para os Romanos, os sacrifícios obedeciam a um ritual muito rigoroso e preciso. Daí a caracterização de "perfeitos». 
estádio ${ }^{289}$ de altura. Tinha um facho na máo esquerda e, na direita, uma espada com qualquer coisa como vinte côvados ${ }^{290}$. $\mathrm{Na}$ parte de baixo do corpo, tinha pés em forma de serpente, enquanto na parte de cima se parecia com uma Górgona, isto é, tinha um aspecto e um olhar aterradores. Em vez de cabeleira, tinha à volta da cabeça uns dragóes que formavam como que anéis, se enrolavam no pescoço e se espalhavam, alguns deles, por sobre os ombros. Vede, meus amigos - exclamou Êucrates -, como fiquei arrepiado só de falar no assunto. (E ao mesmo tempo que dizia isto, Êucrates mostrava a todos nós os pêlos dos braços eriçados de medo.)

23. Enquanto isso, Íon, Dinómaco e Cleodemo, de boca aberta e olhos esbugalhados, escutavam-no com toda a atençáo, eles, já uns velhos, presos pelo beicinho ${ }^{291}$, a venerarem, na maior das calmas, um colosso assim tão inverosímil, uma mulher com meio estádio de altura, uma espécie de espantalho gigantesco. E eu pensava comigo mesmo que esses homens, que falam de sabedoria aos jovens e são admirados por tanta gente, diferem das criancinhas apenas pelos cabelos brancos e pela barba, pois, quanto ao resto, são mais fáceis de levar ao engano do que essas criancinhas.

24. Aqui interveio Dinómaco: Diz-me cá, ó Êucrates, os cães da divindade que tamanho tinham?

Eram mais altos que elefantes, dos da India - respondeu Êucrates -, negros como eles e também peludos, com uma pele encardida e imunda. Ao ver a mulher, virei para o lado de dentro da mão o engaste do anel que o árabe me tinha dado. Então Hécate, batendo no chão com o seu pé de dragão, fez que se abrisse um fosso enorme, com uma fundura que chegava ao Tártaro, $e$ lançou-se imediatamente nele. Ai eu, ganhando coragem, debrucei-me [sobre o abismo], segurando-me a uma árvore que estava ali perto, para que a vertigem não me fizesse cair de cabeça. Foi então que observei tudo o que existe no Hades: o rio Piriflegetonte ${ }^{292}$, o lago, Cérbero e os mortos, alguns dos quais até cheguei a reco-

${ }^{289}$ O valor do estádio variava de cidade para cidade: $192 \mathrm{~m}$ em Olímpia, 181 em Epidauro, 177 em Delfos e Atenas...

${ }^{290}$ Cerca de 130 metros.

${ }^{291} \mathrm{O}$ gr. diz literalmente «arrastados pelo nariz».

${ }^{292}$ Piriflegetonte significa "de chamas ardentes». 
nhecer. Por exemplo, vi o meu pai, vestido exactamente como o haviamos sepultado.

E então, ó Eucrates - perguntou Íon -, que é que faziam as almas?

Ora... - respondeu ele - que havia de ser? Passavam o tempo estendidas pelos bosques de asfódelo ${ }^{293}$, com os amigos e os parentes, agrupados por tribos e fratrias.

Ora ai está! - comentou Íon -. Venham agora os epicuristas contradizer o divino Platão e a sua teoria das almas. Mas tu viste mesmo Sócrates e Platão entre os mortos?

Sócrates, vi, sim - respondeu Êucrates -, mas não muito nitidamente: deduzi que era ele, pela calvicie e pelo ventre saliente. Quanto a Platão, de facto não o reconheci (realmente, náo se deve mentir aos amigos). Mas mal tinha acabado de ver tudo isto com toda a nitidez, eis que o fosso se fecha. Nesse instante, chegaram alguns criados, entre os quais aqui o Pirrias, que vinham à minha procura... ainda o fosso não estava completamente fechado. Diz lá, Pirrias, se náo estou a falar verdade.

Sim, por Zeus - disse ele -, até ouvi latidos que vinham do fosso, e pareceu-me entrever o brilho da chama dum facho.

Aqui, desatei a rir, ao ouvir a testemunha acrescentar a luz do facho e os latidos.

25. Nesse momento, interveio Cleodemo: O que tu viste náo é novidade, pois outros já o observaram: eu mesmo assisti a um espectáculo semelhante, ainda não há muito tempo, quando estive doente. Aqui o Antígono tinha vindo visitar-me para tratar de mim. Havia já sete dias que estava com febre, uma febre mais abrasadora que canicula. O pessoal de casa tinha-me deixado a sossegar: fecharam a porta do quarto e ficaram de fora à espera. Foste tu, Antígono, que lho havias ordenado, para que eu pudesse gozar de um pouco de sono. Ainda eu estava acordado, e eis que me aparece um formosissimo jovem, de alvo manto vestido, que me mandou levantar e me conduziu por um fosso até ao Hades, onde logo reconheci Tântalo, Tício ${ }^{294}$ e Sísifo... Mas... para quê entrar em mais pormenores? Logo que cheguei ao tribunal (onde estavam

293 O asfódelo é uma planta liliácea, de raiz tuberosa e belas flores ornamentais, segundo os dicionários.

${ }^{294}$ Gigante, filho da Terra. Estava no Hades a expiar o crime de ter tentado raptar Latona, mãe de Apolo. Tântalo, Sísifo e Prometeu (que sofreu um castigo idêntico ao de Tício) são outros grandes e célebres condenados. 
Éaco, Caronte e as Moiras ${ }^{295}$ ), vi uma personagem sentada, na atitude de rei (pareceu-me Plutão): seleccionava os nomes daqueles que iriam morrer, uma vez que sucedia terem já ultrapassado os dias que lhes coubera viver. Então o jovem conduziu-me à presença do rei. Mas Plutão ficou furioso e disse ao meu condutor: "O fio deste homem ainda não chegou ao fim. Portanto, que saia já daqui para fora! Traz-me mas é o ferreiro Dêmilo, pois já viveu mais do que lhe permite o seu fuso." Então eu, todo contente, sai dali, mas já sem febre, e anunciei a todo o pessoal da casa que Dêmilo estava a morrer. Este homem morava na nossa vizinhança, e dizia-se que estava um tanto adoentado. E de facto, passado pouco tempo, ouvimos os gritos de lamentação pela sua morte.

26. Que grande admiração - disse Antígono -: eu conheço um individuo que ressuscitou, vinte dias depois de ser sepultado. Tratei dele antes de morrer e depois de ressuscitar.

Mas então - perguntei eu - como é que, durante esses vinte dias, nem o corpo apodreceu nem o sujeito morreu de fome? A não ser que tu tenhas tratado um outro Epiménides ${ }^{296}$.

27. Estávamos nós nesta conversa, quando chegaram da palestra os filhos de Êucrates (um já havia deixado a classe dos efebos $^{297}$, e o outro andava pelos quinze anos), que nos cumprimentaram e se foram sentar no leito junto do pai. A mim trouxeram-me um cadeirão ${ }^{298}$. Então Êucrates, como se o facto de ver os filhos lhe recordasse algo, exclamou:

Juro, Tiquiades, pela felicidade destes (e colocou a mão sobre eles) que é verdade o que vou contar-te. Todos sabem como eu amei a minha mulher, mãe destes rapazes, amor esse que eu demonstrei náo só pelo que lhe fiz em vida, mas também quando ela morreu, ao juntar e queimar todos os seus artigos de beleza, bem como todos os vestidos de que ela gostava em vida. Ora, sete dias depois da sua morte, estando eu reclinado aqui no leito, como estou agora, tentava acalmar a minha dor, lendo tranquilamente o livro de Platão sobre

295 Éaco era um dos três juízes do Hades (com Minos e Radamante); Caronte era o barqueiro que transportava as almas dos mortos; e as Moiras eram as três divindades do destino inflexível, acima dos próprios deuses.

${ }^{296}$ Este Epiménides dormiu durante 50 anos...

${ }^{297}$ A classe etária dos efebos ia dos 18 aos 20 anos.

298 Recorde-se que a posição regular era a de reclinado no leito. O cadeirão foi uma solução de recurso. 
a [imortalidade da] alma. Nisto, Deménete, minha mulher, em pessoa, entra na sala e senta-se junto de mim, na posição em que agora está Eucrátides (e Êcrates apontava para o filho mais novo, que logo se pôs a tremer como uma criança e começou a ficar pálido com a história). Assim que a vi - disse Êucrates -, abracei-me a ela, gritando de dor e chorando. Ela, porém, não me deixou continuar com os meus gritos, pois começou a censurar- me pelo facto de eu, tendo feito um sacrifício com tudo o que lhe havia pertencido, não ter queimado uma das sandálias bordada a ouro, que ela dizia ter caido para debaixo duma arca. Por isso nós não a tínhamos achado, pelo que queimámos apenas a outra. Estávamos nós nesta conversa, quando uma maldita cadelinha de Malta, que estava debaixo do leito, soltou um ladrido. Devido a isso, minha mulher desapareceu. Quanto à sandália, foi de facto encontrada debaixo da arca, e em seguida queimada.

28. Então, Tiquiades [- concluiu Êucrates -], continuas a achar que não se deve acreditar em coisas destas, tão evidentes e que acontecem todos os dias?

Não, por Zeus - respondi -. Realmente, aqueles que não acreditam nisso revelam tamanha falta de respeito pela verdade, que merecem apanhar com uma sandália no rabo, como as crianças.

29. Neste momento, chegou o pitagórico Arignoto, com a sua longa cabeleira e o seu aspecto venerando (tu conhece-lo: é um sujeito famoso pela sua sabedoria, a que chamam santo). $\mathrm{Eu}$, assim que o vi, até respirei fundo, cuidando que vinha aí uma ajuda, qual machado contra as mentiras. "Este homem - dizia comigo mesmo - vai calar a boca a estes fulanos que dizem enormidades absurdas. Eu diria mesmo que é, como sói dizer-se, um deus ex machina aqui trazido por Fortuna para me ajudar". Cleodemo cedeu-lhe o seu lugar e o homem sentou-se. Começou por perguntar "como ia essa doença". Uma vez informado pelo próprio Êucrates de que já estava melhor, disse:

Sobre que é que estais a filosofar? Ao entrar, ouvi qualquer coisa, parecendo-me que a matéria em discussão já estava perfeitamente estabelecida.

Ora... - respondeu Êucrates -, que é que havia de ser? Estamos a tentar convencer esta cabeça dura (e apontava para mim) de que existem espiritos e fantasmas, e que as almas dos mortos erram pelo mundo e aparecem a quem querem. 
Aqui eu corei e baixei a cabeça, por respeito a Arignoto, que disse: Repara, Eucrates, talvez Tiquiades não tenha dito bem isso, mas sim que só erram pelo mundo as almas daqueles que morreram de morte violenta, como, por exemplo, a alma duma pessoa que se enforcou, ou a quem cortaram a cabeça, ou que foi empalada, ou, enfim, que deixou esta vida por qualquer outra forma semelhante. Sim, se é isso que ele afirma, as suas palavras não serão de deitar fora.

Por Zeus! - interveio Dinómaco -, no que ele náo acredita é que essas coisas existam ou possam ser materialmente vistas ${ }^{299}$.

30. O quê?! - disse Arignoto, fixando-me com olhar furibundo -, não acreditas que estes fenómenos sejam possiveis de acontecer, quando, por assim dizer, toda a gente os vê?

Mas - observei - tu estás a falar em meu favor: eu não acredito, porque sou o único, entre todos, que não os vejo. Se os visse, é claro que acreditaria, como vós.

Pois muito bem - disse Arignoto -, se alguma vez fores a Corinto, pergunta onde é a casa de Eubátides. Quando ta indicarem (fica para os lados do Cranion), entra e diz ao porteiro Tibio que desejas ver o sitio onde o pitagórico Arignoto abriu uma cova, donde fez sair um espirito, tornando a casa habitável.

31. Ó Arignoto - perguntou Êucrates -, como é que isso foi?

A casa - disse Arignoto - estava há muito desabitada, devido aos horrores [que lá se passavam]. Se alguém ousava habitá-la, tinha logo de fugir, pois era atacado e perseguido por um fantasma aterrador e turbulento. Por isso, a casa estava em ruinas, com o tecto a cair, e náo havia ninguém que tivesse a coragem de ir para lá morar. Ora eu, ao ouvir tal coisa, peguei nos meus livros (tenho muitissimos livros egipcios sobre essas matérias) e dirigi-me a essa casa, à hora do primeiro sono, não obstante ser disso dissuadido pela pessoa em casa de quem estava hospedado, a quem só faltou segurar-me, assim que soube aonde é que eu ia: para a minha perdição, na sua opinião. Então eu peguei numa candeia e entrei sozinho. Depois, coloquei a candeia no quarto maior e comecei a ler, tranquilamente sentado no chão. Então aparece o espirito, que, cuidando tratar-se duma pessoa vulgar, esperava amedrontar-me, como fizera com as outras pessoas.

${ }^{299}$ Uma questão filosófica importante, já desde Sócrates e Platão, era a da existência real das entidades incorpóreas, nomeadamente as Ideias. Daí que também os fantasmas pudessem materializar-se. 
Era imundo, de cabelos compridos e mais negro que as trevas. Avançando para mim, tentava atacar-me por todos os lados, a ver por onde podia pegar-me. Transformava-se ora em cáo, ora em touro, ora em leão. Mas eu lancei máo do meu encanto mais terrivel, falando-lhe em egipcio. E assim o fui encantando, até o empurrar para um canto duma sala às escuras. Tendo reparado bem no sitio onde ele se tinha metido pelo chão abaixo, passei o resto da noite a repousar. Logo de manhä, quando toda a gente estava sem esperança, julgando encontrar-me morto (como sucedera com os outros), eis que, perante a surpresa geral, eu saio cá para fora e dirijo-me a casa de Eubátides, a quem dou a boa-nova de que já podia habitar a casa, agora purificada e livre de medos. Depois, acompanhado por ele e por muitas outras pessoas que me seguiam atraidas por este fenómeno extraordinário, dirigi-me para o sitio onde vira o espirito meter-se pelo cháo abaixo e ordenei que trouxessem pás e enxadas e começassem a cavar. Assim fizeram, $e$, tendo cavado cerca de uma braça, encontraram um cadáver já muito antigo, em que apenas os ossos, muito bem compostos, indicavam a forma do corpo humano. Tirámo-lo para fora $e$ demos-lhe sepultura. Quanto à casa, dai em diante deixou de estar assombrada por fantasmas.

32. Depois de Arignoto, esse homem duma sabedoria divina e venerado por todos, assim ter falado, não houve ninguém entre os presentes que náo me acusasse de grande demência, por náo crer em tais coisas, para mais narradas por um Arignoto. Eu, porém, sem me atemorizar nem com a sua cabeleira comprida nem com o conceito em que ele era tido, disse:

Que é isto, Arignoto? Também tu, que eras a minha única esperança de verdade, te revelas impregnado de fumaça e visóes fantásticas? É caso para repetir a teu respeito o provérbio: "Tu, nosso tesouro, transformaste-te em carvão".

Pois bem - disse Arignoto -, se não acreditas nas minhas palavras, nem nas de Dinómaco, de Cleodemo ou do próprio Eucrates, então vamos lá, cita-me alguém que seja mais digno de crédito nesta matéria e que contradiga o que nós dissemos.

Por Zeus! - respondi -, posso citar o admirável homem de Abdera, o ilustre Demócrito, o qual estava tão convencido de que coisas como essas não podem materializar-se, que se encerrou num jazigo fora de portas e ai permanecia noite e dia a escrever e compor as suas obras. Então uns jovens, querendo rir à custa dele e 
assustá-lo, envergaram roupas negras como as dos mortos, puseram máscaras a imitar caveiras e foram dançar à sua volta, batendo com os pés em ritmo compacto. Demócrito, porém, não se deixando intimidar pelo disfarce, nem sequer levantou os olhos para eles, mas, continuando sempre a escrever, disse: "Deixem-se de brincadeiras!'. A tal ponto estava firmemente convencido de que as almas não são nada, uma vez fora dos corpos.

O que estás a dizer - comentou Êucrates - é que Demócrito era um homem falho de sentido critico, se realmente pensava desse modo. [E continuou:]

33. Pois então vou contar-vos um outro facto, que não ouvi contar a ninguém, mas que se passou comigo mesmo. Talvez que tu, Tiquiades, ao ouvi-lo, te deixes render à verdade da minha narrativa. Com efeito, quando, ainda jovem, vivia no Egipto (para onde meu pai me enviara, a fim de ai ser educado), um dia senti o desejo de subir o rio até Copto, e dai visitar a estátua de Mémnon, para ouvir aquele som maravilhoso que ela solta ao nascer do sol. E de facto, o que eu ouvi não foi um som confuso, como sucede com o comum das pessoas, mas o próprio Mémnon, que abriu a boca e me deu um oráculo de sete palavras, que eu vos citaria, se isso não fosse supérfluo.

34. Ora [- continuou -] sucedeu que, durante a subida do rio, viajava connosco um homem de Mênfis, um dos escribas sagrados, pessoa de admirável sabedoria, que conhecia toda a cultura dos Egipcios. Dizia-se que tinha vivido vinte e três anos nos santuários subterrâneos, onde fora instruido na magia pela própria Ísis.

Referes-te - disse Arignoto - a Pâncrates, o meu mestre, um santo homem, de cabeça rapada, com uma leve túnica de linho, sempre em meditação, falando um grego não muito correcto ${ }^{300}$, alto, de nariz achatado, lábios grossos, pernas adelgaçadas.

Esse mesmo - respondeu Êcrates -, esse mesmo, Pâncrates. Ora bem: ao principio, eu não sabia quem ele era, mas depois, ao vê-lo, sempre que o barco atracava, operar grande número de prodígios (como, por exemplo, montar crocodilos e nadar junto destes animais, que se lhe mostravam dóceis e lhe abanavam as caudas), fiquei a saber que se tratava dum santo homem. A pouco e pouco, fui-me insinuando no seu espirito, até que, quase sem dar por isso, me tornei seu companheiro e amigo intimo, de tal modo,

${ }^{300}$ Um outro grupo de manuscritos diz «falando um grego correcto». Para o caso, tanto faz... 
que ele me transmitiu todos os segredos. Por fim, convence-me a deixar todos os meus criados em Mênfis e a segui-lo sozinho, pois não iriamos ter falta de quem nos servisse. Eis como passámos a viver dai em diante:

35. Logo que chegávamos a uma hospedaria, o egipcio pegava numa tranca de porta, ou numa vassoura, ou num pilão de almofariz, vestia-lhe um manto, recitava uma fórmula mágica e punha-o a andar, em tudo semelhante a um homem. Este ia buscar água, cozinhava, arrumava a casa, enfim, executava todos os serviços e ajudava-nos com muita habilidade. Depois, quando já nâo tinha necessidade dos seus serviços, recitava outra fórmula mágica e voltava a transformar a vassoura em vassoura, ou o pilão em pilão, etc. Embora eu tivesse um grande desejo de aprender essa magia, não havia maneira de ele ma ensinar. De facto, era muito cioso nesse ponto, embora em tudo o mais fosse bastante acessivel. Ora um dia, tendo-me escondido num canto mais obscuro, escutei, sem ele se aperceber, a fórmula mágica, que tinha três silabas. Em seguida, o egípcio ordenou ao pilão o que este tinha de fazer, e foi para a praça pública.

36. No dia seguinte [- continuou Êcrates -], aproveitando o facto de ele estar a tratar dum assunto na praça pública, peguei no pilão, vesti-o, pronunciei exactamente as três silabas e ordenei-lhe que fosse buscar água. Logo que a ânfora ficou cheia, disse ao piläo: "Pára, deixa de carregar água, torna-te outra vez pilầ!". Ele, porém, não quis obedecer, mas continuava a transportar água, a ponto de alagar a casa toda. Já sem saber o que fazer (tinha receio de que Pâncrates regressasse e ficasse zangado - o que sucedeu), pego num machado e corto o piláo em duas partes. Ai, cada uma das partes pega numa ânfora e vai buscar água. Quer dizer: em vez de um criado, fiquei com dois. Nisto, chega Pâncrates, que, percebendo logo o que acontecera, os transformou novamente em madeira, como eram antes do encantamento. Depois deixou-me: sem eu saber como, desapareceu e foi náo sei para onde.

Então e tu - perguntou Dinómaco - ainda sabes transformar um pilão em homem?

Sim, por Zeus! - respondeu Êcrates -... pelo menos por metade. Não sou é capaz de fazê-lo retomar a forma primitiva: uma vez transformado em aguadeiro, era mais que certo que a casa ficaria completamente alagada. 
37. Mas - intervenho eu - quando é que vós, já uns velhos, deixareis de dizer essas enormidades? Se não estais dispostos a isso, pelo menos, por respeito a estes jovens, situai noutros tempos essas histórias bizarras e aterradoras, para que eles, sem de tal se aperceberem, náo se encham de medos e histórias fantásticas. Sim, há que poupá-los, não os acostumando a ouvir tais narrativas, que os acompanharão e perturbarão por toda a vida, enchendo-lhes a cabeça de tanta superstição e tornando-os medrosos.

38. Lembraste bem - disse Êcrates -, ao falar de superstição: que é que tu pensas de coisas como oráculos, profecias e coisas dessas, proferidas por pessoas inspiradas pela divindade ou que se ouvem vindas do interior dos santuários, ou dos oráculos em verso da sacerdotisa, em que ela prediz o futuro? Será que também descrês disso? Pois bem: eu possuo um anel sagrado, que tem gravada na pedra a imagem de Apolo Pitio. Este Apolo fala-me... Mas deixemos isso, não vás tu julgar que estou a gabar-me duma coisa incrivel que se passa comigo. Quero antes contar-te o que ouvi no santuário de Anfíloco, em Malo ${ }^{301}$, onde o herói em pessoa conversou comigo e me aconselhou sobre os meus negócios. Depois contar-te-ei o que vi em Pérgamo e ouvi em Pátara ${ }^{302}$. Ora, ao regressar do Egipto a caminho da minha terra, tendo ouvido dizer que o referido oráculo de Malo era o mais famoso e verdadeiro de todos, que dava oráculos precisos e respondia à letra ${ }^{303}$ ao que os consulentes tinham escrito na tabuinha entregue ao profeta, julguei por bem aproveitar o trajecto e experimentar o oráculo, consultando a divindade com respeito ao meu futuro...

39. Estava Êcrates nesta dissertação, quando eu, vendo até onde ia chegar a conversa e a forma como ele dava início a uma pequena tragédia sobre os oráculos, e, por outro lado, entendendo que não parecia bem ser eu a única pessoa a contradizê-lo em tudo, deixei-o ainda a navegar entre o Egipto e Malo, pois

${ }^{301}$ Cidade da Cilícia, na Ásia Menor (em frente de Chipre).

302 Cidade da Lícia, na Ásia Menor (em frente de Rodes).

303 Isto de o oráculo responder à letra ao que se perguntava tinha a maior importância para o consulente, pois geralmente a resposta era muito confusa, obrigando o fiel a uma interpretação pela qual era, naturalmente, o único responsável. 
também compreendi que eles se sentiam importunados com a presença dum hábil contraditor das suas mentiras. Então disse:

Bem, vou-me embora, vou procurar Leôntico, pois tenho necessidade de tratar dum assunto com ele. Quanto a vós, que não julgais já bastantes as coisas humanas, invocai os deuses, para que vos ajudem nas vossas histórias prodigiosas.

E dizendo isto, saí, enquanto eles, exultantes por terem recuperado a liberdade, festejavam, naturalmente, e atafulhavam-se de mentiras.

Depois de ouvir tais histórias em casa de Êcrates, por Zeus!, ó Fílocles, estou aqui como aquelas pessoas que beberam vinho doce em demasia: tenho o estômago inchado e sinto vontade de vomitar. Estaria até disposto a pagar bom dinheiro por um remédio que me fizesse esquecer o que ouvi, não vá essa lembrança instalar-se em mim e provocar-me algum mal. Realmente, já só me parece ver monstros, espíritos e Hécates.

40. FÍlocles - Tal foi também, Tiquíades, o efeito que essa história teve em mim. Até se diz que não são só aqueles que são mordidos por cães raivosos que apanham raiva, mas também todo aquele que é mordido por uma pessoa com raiva pode ser contaminado, como se fosse por um cão. Ora, parece que tu, que foste mordido por incontáveis mentiras em casa de Êcrates, me transmitiste a mordedura, tendo-me, desse modo, enchido o espírito de fantasmas.

TIQUÍADES - Anima-te, meu querido amigo, pois conheço um poderoso antídoto contra esse mal: a verdade e o justo espírito crítico. Se soubermos usar dele, nenhuma dessas balelas vazias e vãs nos perturbará. 


\section{Apontamento Bibliográfico}

ALLINSON, F. G., Lucian, satirist and artist. Londres, Harrap, 1927.

CASTER, M., Lucien et la pensée religieuse de son temps. Paris, Les Belles Lettres, 1938.

(Sobre o espírito positivo de L. e a sua reacção ao misticismo generalizado do seu tempo).

CROISET, M., Essai sur la vie et les oeuvres de Lucien. Paris, Hachette, 1882 .

(Apesar de já «velhinha», continua a ser a obra de fundo sobre Luciano)

GALLAVOTTI, C., Luciano nella sua evoluzione artistica e spirituale. Lanciano, Carabba, 1932.

(Obra também «antiga», mas importante).

HEWITT, J. W., «A second century Voltaire». In Classical Journal, 1925 (XX), pp. 132-142.

(Este curto artigo trata dum dos aspectos mais importantes e salientes de Luciano, a veia satírica e corrosiva que faz lembrar Voltaire).

MARTHA, C., «Le scepticisme religieux et philosophique: Lucien». In Les moralistes sous l' Empire Romain, $3^{\mathrm{a}}$ ed., Paris, Hachette, 1872, pp. 338-384.

SCHWartZ, J., Lucien de Samosate. Philopseudès et De Morte Peregrini, avec introduction et commentaire. Paris, Les Belles Lettres, 1951. 
(Página deixada propositadamente em branco) 
[OS DOIS] AMORES 
(Página deixada propositadamente em branco) 


\section{[OS DOIS] AMORES}

\section{INTRODUÇẤO}

Antes de mais, diga-se que o título da obra é apenas "Е $\omega \tau \varepsilon \varsigma$ (Érōtes), port. Amores. O contexto, todavia, revela explicitamente que se trata de dois tipos bem definidos de relaçóes amorosas: de homem com mulher, e de adulto com rapazinho. Ficam de fora as relaçóes entre mulheres (v., no entanto, $\$ 28$ e nota ao termo tríbades), entre adultos e entre um adulto e uma menina. Daí que o próprio título grego seja desadequado, mas náo de forma absoluta, pois o leitor antigo, mais ou menos contemporâneo da obra, mesmo antes de verificar do que se trata, já pressupóe que esses Amores se referem aos dois tipos de relaçáo sexual mais comuns ou, pelo menos, mais susceptíveis de serem discutidos numa obra de tese - pressuposição que certamente não estará no espírito de um leitor moderno. Assim, o título mais explícito em português seria algo como Relaçôes Heterossexuais e Relaçôes Pedófilas, e, mesmo assim, o termo pedófilo, ainda que suscite naturalmente a ideia de "relaçóes entre adulto e menino", náo exclui necessariamente a ideia de "relaçóes entre adulto e menina». Geralmente os tradutores limitam-se a traduzir por Amores, mas o tradutor da ed. Loeb ousa verter gr. Érotes para "Affairs of the Heart», de modo excessivamente ... romântico, que náo deixa pressupor nada do conteúdo do livro, mas que revela, isso sim, uma real dificuldade de traduçáo.

A nossa versão por [Os Dois] Amores serve, pois, o propósito de explicitar um pouco, e desde o início, o conteúdo da obra.

Os comentadores modernos estáo geralmente de acordo em considerar que esta obra náo é da autoria de Luciano. De facto, quem estiver minimamente familiarizado com a leitura de outras obras indiscutivelmente de Luciano, nota logo a diferença. $\mathrm{O}$ tradutor, esse mais que qualquer outro leitor, não reconhece aqui o "velho" Luciano, senhor de uma prosa límpida e linear, de uma sintaxe muito regular e de um vocabulário geralmente ático. Nesta obra, pelo contrário, a ordem das palavras é rebuscada e, por vezes, muito confusa; a sintaxe é bastante frouxa; o vocabulário apresenta umas vezes um carácter escusadamente 
poético, outras vezes popular, o que denota um escritor que pretende obter um estilo elevado, mas que, não raro, cai em vulgarismos da língua sua contemporânea, que parece nitidamente a koinê de uma época tardia... A menos que se trate de outra coisa. Quer dizer:

Em teoria, pode acontecer que o jovem Luciano, sírio de nascimento e língua, mas estudioso da língua grega clássica e também conhecedor da koinê, tente "traduzir» para grego a estrutura mais profunda do seu pensamento, misturando os ensinamentos da escola e as leituras dos prosadores e poetas com a linguagem vulgar e o substrato da língua síria. Alguma palavras têm, pelo contexto, um sentido muito forçado, que parece devido à falta de sentimento íntimo da língua grega. Poderia, pois, acontecer que esta obra, de cariz sofístico, constituísse um exercício de habilidade retórica e dialéctica, em que se defendem duas teses opostas. Então, o seu jovem autor (Luciano?), desejoso de mostrar a sua habilidade linguística, cai em excessos de preciosismo ou, sem disso se aperceber, em incongruências semânticas e sintácticas e em vulgarismos correntes no seu tempo. Poderia ser...

Muito provavelmente, os [Dois] Amores não são da autoria de Luciano; essa é a intuição natural do leitor e estudioso moderno, mas - repito - nada nos impede de admitir que o jovem sírio, acabado de se formar em sofística, mas ainda um tanto incipiente nos segredos da língua grega, tenha produzido esta obra de aparato e de acribia, com os defeitos já referidos.

Do ponto de vista da estrutura, tirando a introdução e a conclusão (e mais alguns apontamentos pelo meio), [Dois] Amores articulam-se em dois discursos, pronunciados, não pelos respectivos oradores, mas, em estilo directo, pela boca do narrador, de nome Licino (Luciano, é claro), que tem como interlocutor (ouvinte!) o seu amigo Teomnesto.

Um dos antagonistas, Cáricles de Corinto, era «um jovem a quem não falta beleza e que, para mais, se apresentava com tratamento cosmético, naturalmente, creio eu, para agradar ao mulherio", ou seja um defensor da prática sexual de homem com mulher, ao passo que o outro, Calicrátidas de Atenas, era «homem... muito dado a exercícios físicos, não tanto, creio eu, por gostar de ginásios, mas sobretudo pela sua paixão por rapazinhos..."

Deixo ao leitor moderno a tarefa de analisar os argumentos de cada um dos antagonistas. 


\section{[OS DOIS] AMORES}

1. LICINO - Já desde manhãzinha que tu, meu amigo Teomnesto, tens enchido de aventuras amorosas os meus ouvidos, que já andavam cansados de incessantes assuntos sérios... e eis que jorrou, e bem a propósito, a graça das tuas divertidas histórias, precisamente quando eu estava avidamente sequioso de um alívio desse género. De facto, o espírito é fraco no que toca a suportar contínuos assuntos sérios, pelo que as duras actividades prestigiantes requerem que uma pessoa se alivie um pouco de graves reflexóes e se entregue aos prazeres. Ora, toda esta manhã me encantou o fascinante e suave poder de insinuação das tuas histórias libertinas, de tal modo, que pouco faltou para que eu me julgasse um outro Aristides, de tâo encantado que fiquei com essas tuas... "Histórias Milesianas»" ${ }^{304}$. Só tenho pena - juro pelos teus Amores, para os quais tu te revelaste um alvo tão largo - é de que tenhas terminado a narração. Assim, em nome da própria Afrodite te rogo, se achas que ainda tens mais aventuras notáveis para $\mathrm{me}^{305}$ contar, e no caso de teres sentido um desejo ardente, quer por macho quer por fêmea, que o evoques na tua memória com toda a tranquilidade, pois, além do mais, celebramos hoje com sacrifícios o dia festivo de Héracles. Ora, certamente que não desconheces que esse deus é muito ardente nos assuntos de Afrodite, pelo que julgo que ele vai deliciar-se com os... "sacrifícios» que são as tuas histórias.

\section{TEOMNESTO - Ó Licino, mais facilmente contarias as} ondas do mar ou os densos flocos de neve que caem do céu, do que o número dos meus Amores ${ }^{306}$. $\mathrm{Na}$ verdade, creio ter

${ }^{304}$ Aristides de Mileto (c. de 100 a.C.) foi o autor das famosas Mi $\lambda \eta$ $\sigma \iota \alpha \kappa \alpha ́$, Histórias (Fábulas, Contos) Milesianas, traduzidas para latim por Sisena; o seu conteúdo era vincadamente erótico e até obsceno. Estas Histórias eram bastante conhecidas até muito tarde, mas acabaram por se perder.

305 Aqui, os manuscritos dão uma lição algo difícil, pelo que tem sido emendada por editores modernos. Tentei manter a lição dos mss., considerando o pronome $\mu \varepsilon$, em acusativo, como complemento indirecto, o que representa uma tendência popular, que ocorre desde muito cedo, é corrente no grego bizantino vulgar e chega a certos dialectos neo-helénicos. Este caso, juntamente com outros, poderia apontar para uma autoria que náo a de Luciano, e até para uma data posterior.

${ }^{306}$ Amores, com maiúscula e no plural, não só para significar as muitas vezes em que Eros o atingira com as suas setas, conforme fica explícito 
deixado completamente vazia a sua aljava, de modo que, se eles decidirem voar contra qualquer outra pessoa, a sua mão direita desarmada será motivo de troça. De facto, desde a idade em que passei da meninice para ser incluído na classe dos adolescentes, ando "pastando» de umas «pastagens» para outras $^{307}$, em amores que se sucedem uns aos outros: antes que uns acabem, vêm outros, quais cabeças de Lerna, mas mais entrelaçadas que as da Hidra ${ }^{308}$, sempre regeneradas, contra as quais nada pode a ajuda de nenhum Iolau, pois um fogo não se extingue com outro fogo. Assim, habita nos meus olhos um certo estímulo sensual, que atrai a si todas as beldades, sem nunca me dar por saciado. E muitas vezes me vem à mente a pergunta: Que cólera é esta de Afrodite contra mim? Na verdade, não sou nenhuma filha do $\mathrm{Sol}^{309}$, nem me orgulho das insolências das mulheres de Lemnos ou do feroz desprezo de Hipólito, a ponto de ter ateado esta incessante cólera da deusa.

3. LICINO - Ó Teomnesto, deixa-te dessa dissimulação artificial e desagradável. Sim, será que te sentes incomodado por a sorte te ter atribuído esse género de vida, e consideras penoso o facto de teres relaçóes com mulheres formosas ou com rapazes na flor da beleza? Nesse caso, precisas urgentemente de um purgante que te limpe desse mal táo desagradável. Realmente, trata-se de uma moléstia terrível! ${ }^{310}$ Mas agora a sério ${ }^{311}$, porque é que não deitas fora esse desvario e não te hás-de considerar feliz pelo

logo a seguir, como para aludir aos dois tipos de paixáo amorosa a que a personagem era igualmente dada.. O uso do plural recorda-nos o verso catuliano: Veneres Cupidinesque...

${ }^{307} \mathrm{Ou}$, saindo da estrita letra, «ando mudando de uma paixão para outra».

${ }^{308}$ Referência à Hidra (ou serpente) da lagoa de Lerna (na Argólida a nordeste do Peloponeso), que foi morta por Héracles. Era um monstro com várias cabeças (entre cinco e... cem), que renasciam cada vez que eram cortadas. Héracles só conseguiu vencer o monstro com a ajuda de Iolau, seu sobrinho e fiel companheiro.

${ }^{309}$ A referência dirige-se especialmente a Pasífae, filha de Hélio (o Sol), mas também às suas irmãs Circe e Medeia. Afrodite tinha forte aversão a Hélio, pelo facto de este ter ido contar a Hefesto, seu marido, os amores da bela Afrodite com Ares; daí a sua vingança, que se estendia aos descendentes de Hélio. As mulheres de Lemnos e o casto Hipólito também não veneravam a deusa do amor, pelo que suscitaram igualmente a vingança de Afrodite.

${ }^{310}$ Há que notar a ironia, como se vê pelo seguimento.

${ }^{311} \mathrm{O}$ texto diz apenas «mas», indicando uma mudança de assunto ou de tom. 
facto de a divindade ${ }^{312}$ não te ter destinado a miserável agricultura, nem as errâncias do comércio ou a vida militar sempre em armas? Pelo contrário, só te preocupas com untuosas palestras, com uma veste resplendente que desça sensualmente até aos pés e com o penteado admiravelmente tratado. $\mathrm{O}$ próprio tormento das paixôes eróticas tem o seu encanto, bem como o doce dente do desejo que nos morde. Ao perseguires, ganhas esperança, e ao alcançares, ganhas prazer, de forma que o prazer futuro é igual ao do presente. Ainda há pouco, quando estavas a enumerar, tal como Hesíodo, o longo catálogo das beldades ${ }^{313}$ pelas quais, desde o início ${ }^{314}$, te apaixonaste, as radiantes centelhas dos teus olhos desfaziam-se em ternura, e, ao amaciares delicadamente uma voz igual à da filha de Licambes ${ }^{315}$, tornava-se desde logo manifesto, pela tua própria expressão, que não estavas apaixonado apenas por esses episódios, mas também pela recordação que deles tinhas. Então, se ainda te ficou [por contar] algum resto da «navegação» nas águas de Afrodite, não me escondas nada, oferece a Héracles um sacrifício completo.

4. TEOMNESTO - Ó Licino, antes de mais, essa divindade é devoradora de bois e, segundo dizem, gosta muito pouco de sacrifícios sem fumo ${ }^{316}$. Mas, como nós celebramos com a palavra a sua festa anual, as minhas histórias, que se prolongaram desde esta manhã [até agora], já causam enjoo. Então, que a tua Musa se desvie da sua ocupação habitual e passe alegremente o resto do dia com o deus ${ }^{317}$, e que tu sejas o meu juiz imparcial, pois vejo que não pendes para nenhum dos dois tipos de paixão, ou seja, quais consideras melhores: os pedófilos ${ }^{318}$ ou os que

312 Trata-se de uma das Parcas, Cloto, aquela que fia o destino das pessoas; em vez de "não te ter destinado", a tradução literal seria "não te ter fiado".

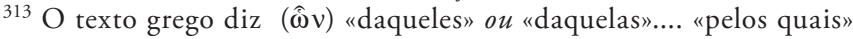
ou «pelas quais»... Tentámos manter a duplicidade.

${ }^{314}$ Entenda-se: «desde a tua adolescência».

315 Trata-se de Neobule, amada pelo poeta Arquíloco.

316 "sacrifícios sem fumo», p. ex., só de... palavreado, e não de vítimas animais, que custam dinheiro, mas são, para os deuses, mais... substanciais. A seguir, faz-se referência precisamente ao sacrifício... verbal.

${ }^{317}$ Refere-se, é claro, a Héracles.

${ }^{318} \mathrm{O}$ termo usado aqui é philópais ( $\left.\varphi \imath \lambda o ́ \pi \alpha \imath \varsigma\right)$, mas também ocorre, com inversão de elementos de composto, paidóphilos ( $\pi \alpha 1 \delta o ́ \varphi \imath \lambda \circ \varsigma)$; em ambos, o elemento philo- tem valor verbal transitivo (cf. port. filó-sofo e pedó-filo). Com outro elemento verbal, existe paiderastês ( $\pi \alpha \imath \delta \varepsilon \rho \alpha \sigma \tau \eta \dot{\varsigma})$, «que tem relaçóes sexuais com rapazes», mas que não corresponde exactamente ao 
gostam de mulheres? É que eu, ferido por ambas as paixões, oscilo equilibradamente, tal qual uma balança aferida, entre ambos os pratos. Tu, porém, como estás de fora, escolherás, segundo o raciocínio de um juiz imparcial, o melhor dos dois tipos. Portanto, meu caro amigo, deixa-te de evasivas e pronuncia-me já a tua sincera sentença a respeito dos meus amores.

\section{LICINO - Ó Teomnesto, cuidas tu que se trata de uma} história só para brincadeira e gracejo? Pois olha que a história anuncia-se como muito grave. Realmente, ainda há pouco tempo tomei contacto com esse tema, e fiquei convencido de que estava muito longe de ser uma brincadeira, desde que escutei dois homens a discutirem acaloradamente sobre isso, de tal modo que a discussão ainda ressoa na minha memória. Divergiam as suas paixóes, tal como divergiam os respectivos argumentos, ao contrário de ti, que, com essa tua capacidade anímica de resistir ao sono, recebes "um duplo salário» ${ }^{319}$,

um como pastor de bois, | outro de niveas ovelhas.

Pelo contrário, um deles sentia um prazer desmedido na relação com rapazes, considerando a feminina Afrodite ${ }^{320} \mathrm{um}$ autêntico ${ }^{321}$ abismo, ao passo que o outro, virgem de quaisquer relaçóes com machos, "voava" para as mulheres. Na verdade, náo seria capaz de exprimir por palavras o enorme prazer que senti por ter desempenhado a função de juiz na disputa entre as duas paixôes em confronto, a ponto de terem ficado gravados nos meus ouvidos os ecos das suas palavras, quase como se tivessem acabado de ser pronunciadas. Portanto, obviando a

port. "pederasta", que ganhou o sentido geral de "homossexual». Diversamente, o port. pedófilo manteve o sentido inicial grego.

${ }^{319}$ Linguagem figurada, para significar que Teomnesto atendia incansavelmente aos dois tipos de paixão. O verso que se segue é tirado da Odisseia, X, 85, com menção, também do v. 84. Naturalmente, é preciso transformar o sentido próprio dos versos da Odisseia em sentido figurado; nomeadamente, "pastor de bois" refere-se à relação com rapazes, e "... de níveas ovelhas" alude ao amor com mulheres. Nota - Tento dar, na tradução (aqui e noutros passos), aspecto métrico, com dois hemistíquios de sete sílabas, separados por uma cesura. Náo corresponde ao hexâmetro dactílico, mas, pelo menos, tem um ritmo bem sensível.

${ }^{320}$ Obviamente, uma metáfora por «relação com mulheres».

321 "autêntico» não consta do texto grego... mas náo é difícil de subentender, como também não o é a ideia de "sem retorno», "sem saída». 
todo e qualquer pretexto para que me censures ${ }^{322}$, vou narrar-te fielmente o que ouvi expor a ambos.

TEOMNESTO - Eu, pela minha parte, vou levantar-me de onde estou e vou sentar-me diante de ti,

aguardando que o Eácida ${ }^{323}$ | ponha termo ao seu cantar ${ }^{324}$,

e que tu, com voz melodiosa, nos cantes as antigas glórias do diferendo amoroso.

6. LICINO - Como eu tencionasse navegar, com muita pressa ${ }^{325}$, para a Itália, foi-me preparado um navio com duas filas de remos, daqueles que, segundo parece, são muito usados pelos Liburnos, povo que habita nas margens do Golfo Jónico. Como me competia, depois de prestar homenagem a todos os deuses da região e de invocar Zeus Hospitaleiro para que me fosse propício e assistisse à minha deslocação ao estrangeiro, desci da cidade até à praia, num carro puxado por mulas. Depois, tendo-me despedido com um aperto de mão dos que me acompanhavam (seguia-me uma multidão muito chegada de intelectuais, que comigo conviviam permanentemente e que tinham pena de se separar de mim), embarquei e fui instalar-me na popa, perto do piloto. Então, com o movimento impetuoso dos remadores, em breve nos afastámos de terra; mas, como logo a seguir soprou uma brisa que nos impelia, içámos o mastro no meio do navio e ajustámos a verga ao cesto da gávea, após o que desfraldámos as velas, que estavam enroladas aos cabos;

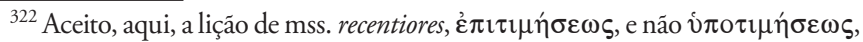
o que daria: «obviando a todo e qualquer pretexto para me furtar (...)».

323 "Eácida», "da família de Éaco», pode referir-se, em primeiro lugar, a Peleu, mas também, como aqui, a seu filho, Aquiles.

${ }^{324}$ Ilíada, IX, 191. Note a versão em versos de $7+7$ sílabas com cesura.

325 Aqui, os mss. mais antigos apresentam dificuldade de interpretação, pelo que alguns mais recentes, bem como editores modernos, procedem a uma correcção; além disso, ocorre a forma * $\tau \alpha \chi v \vee \alpha v \tau o v v$, desconhecida dos dicionários, que poderia ser um barbarismo, equivalente a $\tau \alpha \chi v \vee \alpha v \tau \varepsilon \hat{\imath} \nu$ «navegar

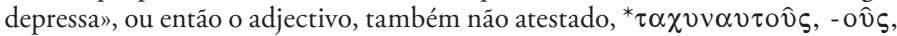
- ô̂V «que navega rapidamente», «rápido», «ligeiro». Qualquer das interpretaçóes poderia ser sustentada por analogia com formas atestadas: inf. ${ }^{*} \tau \alpha \chi \nu \nu \alpha v \tau 0 \hat{v} v$, cf. $\tau \alpha \chi \nu \pi \lambda \circ \varepsilon \dot{\varepsilon} \omega,-\pi \lambda \circ \hat{\omega}$ «navegar depressa»; adj. * $\tau \alpha \chi v \pi \lambda \circ \hat{v} \zeta,-0 \hat{v} \zeta,-o \hat{v}$, cf. $\tau \alpha \chi v \pi$ ópos «que se move rapidamente». Opto pela interpretaçáo de infinitivo ("tencionando navegar com muita pressa»), para não ter de acrescentar, como fazem os mss. mais recentes e alguns editores modernos, a forma $\pi \lambda \varepsilon \hat{\imath} \nu$ «navegar». Este «truque» diz bem da dificuldade há muito sentida. 
a pouco e pouco, a vela foi-se enfunando, e nós vogávamos a uma velocidade em nada inferior, julgo eu, à de uma seta, enquanto a ondulação sussurrava gravemente contra a proa que a sulcava.

7. Não é o momento oportuno para me alongar excessivamente nos episódios, sérios ou jocosos, ocorridos em plena viagem ${ }^{326}$.

Tendo passado pelas costas da Cilícia, entrámos pelo Golfo da Panfília; depois, tendo passado, não sem algum incómodo, pelas ilhas Quelidónias ${ }^{327}$ — as benditas fronteiras da Grécia antiga - desembarcámos em cada uma das cidades da Lícia, que muito nos encantaram com as suas lendas. Na verdade, não se vê nelas qualquer vestígio evidente do seu [antigo] esplendor. Depois, tendo aportado a Rodes, a ilha de Hélio ${ }^{328}$, decidimos descansar um pouco da viagem, até então ininterrupta.

8. Então os remadores arrastaram o barco do mar para terra e armaram as tendas junto dele, enquanto eu, depois de reservar um quarto ${ }^{329}$ em frente do templo de Dioniso, fui dar um passeio com todo o meu vagar e cheio de um enorme prazer. Realmente, a cidade de Hélio possui uma beleza bem digna desse deus. Ao percorrer a toda a volta os pórticos do templo de Dioniso, examinei em pormenor todas as pinturas, relembrando mitos heróicos, ao mesmo tempo que dava prazer aos olhos. De facto, imediatamente dois ou três homens se acercaram de mim, narrando-me toda a história em troca de uma pequena retribuição. Aliás, a maior parte dela já eu tinha percebido por conjectura.

9. Então, estando eu já plenamente satisfeito com o que vira, e tencionando ir-me chegando para casa, eis que deparo com o mais agradável prazer em terra estranha: dois homens, meus

${ }^{326}$ Em todo o caso, o Autor vai alongar-se mais que a conta, até ao $₫ 19$, com pormenores que, embora preparando (de muito longe!) os discursos de dois antagonistas a respeito de duas formas de amor, tiram unidade à obra, pela sua extensão desproporcionada.

${ }^{327}$ Lit. «ilhas das andorinhas», são cinco ilhotas rochosas nas costas da Lícia, c. $63 \mathrm{~km}$ a leste de Rodes, zona conhecida pela agitação das águas.

328 «ilha de Hélio», o deus Sol. No tempo do narrador, já náo estava de pé, à entrada do porto, a famosa e colossal estátua de Apolo, uma das sete maravilhas do mundo, erguida entre 292-280 a.C., e que ruiu, aquando do terramoto de 223 a.C.

${ }^{329}$ A palavra xenôn ( $\left.\xi \varepsilon v \omega ́ v\right)$ refere-se a um quarto para estrangeiros, um alojamento numa espécie de hospedaria. 
íntimos amigos de longa data, que creio não te serem desconhecidos, pois viste-os muitas vezes visitar-me aqui em minha casa, Cáricles de Corinto, um jovem a quem não falta beleza e que, para mais, se apresentava com tratamento cosmético, naturalmente, creio eu, para agradar ao mulherio. Juntamente com ele, estava Calicrátidas de Atenas, homem de maneiras simples, que primeiramente se distinguiu na eloquência política e agora na nossa oratória forense. Além disso, era muito dado a exercícios físicos, não tanto, creio eu, por gostar de ginásios, mas sobretudo pela sua paixão por rapazinhos. De facto, era completamente doido por tal paixão e, cheio de ódio, rogava pragas contra o sexo feminino e contra Prometeu ${ }^{330}$.

Ao avistarem-me de longe, correram ambos ao meu encontro, cheios de alegria e de prazer. Depois, tendo-me apertado a mão, como é costume, cada um deles instava comigo para ir a sua casa. Então eu, vendo-os a discutir assim tâo acaloradamente, disse: "Calicrátidas e Cáricles, hoje, é bom que sejais vós ambos a vir a minha casa, para náo levantardes mais disputa; $e$ nos próximos dias - pois resolvi ficar nesta terra três ou quatro dias - receber-me-eis vós alternadamente, depois de se decidir à sorte quem será o primeiro». E assim ficou decidido.

10. Nesse dia fui eu a recebê-los à mesa; no dia seguinte foi Calicrátidas, e, a seguir a este, Cáricles.

Ora, mesmo durante o banquete [que me ofereceram ${ }^{331}$, verifiquei claros sinais da inclinação de cada um deles. De facto, o ateniense ${ }^{332}$ era servido por formosos moços, e todos os seus criados eram praticamente imberbes, permanecendo em sua casa até que lhes despontasse o primeiro buço; mas, logo que a face se lhes cobria de pêlos, eram despachados como feitores das suas propriedades na Ática.

Cáricles, pelo contrário, estava rodeado por um numeroso bando de bailarinas e tocadoras de música, e toda a casa, como se fosse nas Tesmofórias ${ }^{333}$, estava cheia de mulheres, mas de homens nem

${ }^{330}$ Prometeu criou a mulher... o que lhe tem valido muita praga; cf. $\$ 43$.

331 «que me ofereceram» não está no texto grego, mas é forçoso subentender a ideia, pois, caso contrário, poderia dar a ideia de que se tratava somente do primeiro banquete, oferecido por Licino..

332 Recordemos: Calicrátidas.

${ }^{333}$ As Tesmofórias eram uma festa, celebrada especialmente em Atenas, no mês de Outubro, em honra de Deméter e destinada a assegurar a fertilidade dos campos. Essas celebraçôes eram exclusivamente reservadas às mulheres. 
sombra, a não ser alguma criança ou algum velho cozinheiro, cuja idade não levantava a mínima suspeita de desejo sexual.

Estes factos eram, pois, como já disse, amostras suficientes da inclinação de cada um. Muitas vezes, surgiram mesmo umas breves escaramuças entre eles, mas sem que a discussão chegasse ao fim. Ora, chegado o momento de embarcar, levei-os, a seu pedido, como companheiros de navegação, pois tencionavam, tal como eu, ir para a Itália.

11. Ora, tendo nós decidido aportar a Cnido, a fim de visitarmos o templo de Afrodite, onde é muito gabada a obra verdadeiramente "afrodisíaca» ${ }^{334}$ saída das máos hábeis de Praxíteles, fomos suavemente impelidos para terra, no meio de uma calma deliciosa, por obra, creio eu, da própria deusa, que dirigia o barco. Deixei aos outros as tarefas habituais, enquanto eu, tomando pela mão, um de cada lado, o par de apaixonados ${ }^{335}$, dei uma volta por Cnido, observando, náo sem grandes risadas, as figuras de barro lascivas, próprias da cidade de Afrodite. Em primeiro lugar, percorremos os pórticos de Sóstrato ${ }^{336}$ e todos os outros locais capazes de nos encantar, após o que nos encaminhámos para o templo de Afrodite, nós os dois - eu e Cáricles - com muito gosto, ao passo que Calicrátidas ia muito contrariado, na expectativa de ir ver uma coisa feminina, e trocava de bom grado — julgo eu — a Afrodite de Cnido pelo Eros de Téspias ${ }^{337}$.

12. Então, não sei lá como, começou a soprar sobre nós, vinda do recinto sagrado, uma brisa afrodisíaca. De facto,

${ }^{334}$ O Autor joga com o teónimo Aphroditê ('A $\varphi \rho \circ \delta$ í $\left.\tau \eta\right)$ e o adj., baseado no nome da deusa, epaphróditos (غ่ $\pi \alpha \varphi \rho o ́ \delta ı \tau o \varsigma)$, "que inspira amor», «amável», "encantador», ou (para manter o jogo de palavras)... "afrodisíaco». De resto, nos $\$ \$ 16-17$, conta-se a história da paixão carnal de um jovem por essa estátua.

${ }^{335}$ Naturalmente — como se depreende pelo contexto — náo se trata de apaixonados um pelo outro, mas de dois apaixonados, cada um por seu tipo de paixão: por rapazes ou por mulheres.

336 Sóstrato, famoso arquitecto natural de Cnido, que construiu o célebre farol de Alexandria. Neste passo, refere-se uma obra arquitectónica também admirável, uma série de arcadas, com um terraço, por onde deveria ser muito agradável passear.

337 Téspias, cidade da Beócia, a oeste de Tebas, onde, de cinco em cinco anos, se celebravam festas em honra de Eros (lat. Cupido, o deus Amor). Aí se encontrava uma estátua de mármore de Eros, também da autoria de Praxíteles. Esta preferência, suposta por Licino, vinca bem a tendência de Calicrátidas para a pedofilia. 
o pátio não tem um chão infértil, geralmente pavimentado com placas de pedra polidas, mas, como convém a um templo de Afrodite, todo ele estava coberto de árvores de fruto, que formavam uma abóbada cobrindo o céu a toda a volta com as suas copas luxuriantes a perder de vista. Mas mais que todas as outras, florescia o mirto carregado de frutos, que se desenvolvera magnificamente por acção da sua Senhora ${ }^{338}$, bem como todas as restantes árvores, que patenteavam a sua beleza: nem mesmo a sua já provecta idade as fazia secar e amarelecer ${ }^{339}$, mas, pelo contrário, sempre na força do viço, davam novos rebentos na estação própria. A estas, juntavam-se outras, que, de resto, não davam fruto, mas que tinham por fruto a sua beleza, como os ciprestes e os plátanos, cujo porte se elevava nos ares, e, por entre essas árvores, como que refugiada aos pés de Afrodite, via-se Dafne ${ }^{340}$, que outrora fugia desta deusa ${ }^{341}$; e abraçada a todas as árvores, trepava a hera amorosa ${ }^{342}$; e fecundas videiras vergavam-se ao peso de compactos cachos de uvas, pois Afrodite é mais gostosa na companhia de Dioniso, bem como o prazer conjunto vindo de cada um, ao passo que, separados um do outro, encantam menos. Havia ainda, debaixo das árvores mais sombrias, agradáveis leitos de [verdura] para as pessoas que pretendam fazer aí uma festa, local raramente frequentado por certos cidadãos mais finos, mas aonde acorre em massa a arraia-miúda, para homenagear verdadeiramente Afrodite.

13. Após termos desfrutado suficientemente daquela vegetação, entrámos no templo. A parte central é ocupada pela deusa - uma belíssima obra de arte em mármore de Paros —, que sorri com uma certa arrogância, com um sorriso de

${ }^{338} \mathrm{O}$ mirto era a árvore especialmente consagrada a Afrodite.

339 Normalmente, poliá ( $\pi \mathrm{o} \lambda \iota \alpha$ ) refere-se a "cabelos grisalhos», "cabelos acinzentados»; aqui, naturalmente, alude-se ao aspecto verde-claro ou amarelo das folhas secas.

${ }^{340}$ Dafne, ninfa amada por Apolo, a cuja paixão não correspondia. Perseguida pelo deus, preste a ser apanhada, suplicou a seu pai (o rio Ládon ou o rio Peneu), ou a Zeus, que a transformasse... E foi transformada numa árvore, à

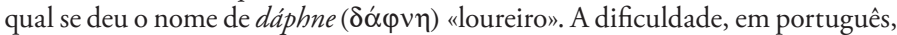
reside no género da palavra: enquanto, em grego, se joga com o par Dáphne (nome da ninfa) e dáphne («loureiro»), em port. não poderíamos dizer que Apolo perseguiu Loureiro (?), o qual (a qual?) se transformou em... loureiro (!).

341 "fugia da deusa», i. é, de Afrodite, metáfora por "fugia do amor».

${ }^{342}$ A hera é a planta consagrada a Dioniso (Baco), deus não só do vinho e das orgias, mas também propiciador da paixão amorosa. 
boca entreaberta. Completamente nua, sem qualquer veste a envolvê-la, toda a sua beleza está a descoberto, com excepção das partes pudendas, que ela discretamente cobre com uma das mãos. A arte do seu criador foi tấo forte, que a natureza tão dura e táo resistente da pedra cede perante [a delicadeza de] todos os membros. Então Cáricles exclamou, como um louco fora de si: "Ó Ares - disse —, o mais venturoso entre os deuses, preso na rede por causa desta deusa!»; e ao mesmo tempo, avançando com lábios sôfregos ${ }^{343}$, beijava-a, estendendo o pescoço o mais que podia. Calicrátidas, porém, permanecia em silêncio, interiormente atónito.

Ora, o templo possui uma porta de cada lado, para os que pretenderem contemplar atentamente a deusa pelas costas, a fim de não deixarem dela nada por admirar. É, pois, muito cómodo, para quem entre pela outra porta, examinar a beleza traseira da deusa.

14. Tendo nós decidido contemplar a deusa por inteiro, demos a volta e entrámos pelas traseiras do recinto. Tendo-nos sido aberta a porta pela sacerdotisa auxiliar encarregada da guarda das chaves, um súbito espanto se apoderou de nós, à vista de tanta beleza. Então o ateniense ${ }^{344}$, que momentos antes olhava para aquilo com indiferença, ao reconhecer as partes da deusa semelhantes às de rapazinho, exclamou em voz muito alta e ainda com mais fúria que Cáricles: "Ó Héracles! Que dorso tão bem proporcionado! Como os flancos são carnudos, num abraço de encher as mãos! Como a carne das nádegas se curva tão graciosamente, nem demasiado magra e pegada aos ossos, nem exageradamente transbordante de gordura! Ninguém poderia exprimir como é suave a graça de duas covinhas marcadas de cada lado dos rins. São exactas as proporçóes da coxa e da perna, que se estende em linha recta até ao pé. Tal e qual Ganimedes, que, lá no céu, serve a Zeus o néctar, ainda mais doce, pois eu não aceitaria essa bebida servida pela mão de Hebe."

Enquanto Calicrátidas assim exclamava com ar apaixonado, pouco faltou para que Cáricles, no extremo do seu espanto, ficasse petrificado, com a paixão a escorrer-lhe lânguida e húmida pelos olhos.

${ }^{343}$ Adopto a emenda de Schaefer, que considera o adj. liparês ( $\left.\lambda \iota \pi \alpha \rho \eta ́ \varsigma\right)$ «insistente», em vez do adj. liparós ( $\lambda \imath \pi \alpha \rho o ́ \varsigma)$ "untuoso», "viscoso», fig. «brilhante (de baba)». Diga-se que a emenda moderna náo é assim tão evidente.

${ }^{344}$ Recorde-se: Calicrátidas, o pedófilo. É curioso notar a sua reacção ao ver o traseiro da deusa. 
15. Depois que a própria saciedade fez cessar o nosso espanto, eis que reparámos numa mancha sobre uma das coxas, parecida com uma nódoa na roupa. A própria alvura geral da pedra punha em evidência essa imperfeição. Ao princípio, conjecturando uma explicação plausível a respeito da verdade do caso, julguei que aquilo que estávamos a ver se devia a uma imperfeição natural da pedra. De facto, não é de excluir um acidente destes, pois muitas vezes uma circunstância acidental impede belas obras de virem a ser perfeitas. Julgando, pois, que aquela mancha negra era um defeito natural, mesmo assim admirei Praxíteles, pelo facto de ter dissimulado o defeito da pedra, pondo-o na parte menos susceptível de ser detectada. Foi então que a sacerdotisa auxiliar que estava junto de nós nos contou uma história inaudita e verdadeiramente incrível. Contava ela que um jovem de uma família nada obscura cujo acto, no entanto, fez que omitisse o seu nome - , o qual visitava frequentemente o templo, se apaixonou pela deusa, levado por um espírito maligno, e, por passar todo o dia no templo, ao princípio deu a impressão de se tratar de uma veneração piedosa. De facto, saindo da cama de manhã, muito antes do nascer do sol, dirigia-se para o templo, e só depois do pôr do sol, e mesmo assim de má vontade, regressava a casa; durante todo o dia, especado em frente da deusa, fixava continuamente sobre ela os raios imóveis dos seus olhos; além disso, desprendiam-se-lhe dos lábios uns murmúrios confusos e queixas de amor expressas entre dentes.

16. Sempre que desejava aliviar-se um pouco da paixão, invocava a deusa, contava sobre uma mesa quatro ossinhos de gazela líbica, e neles jogava a sua esperança: se fazia um lance feliz, sobretudo se lhe saía a própria deusa ${ }^{345}$, sem que nenhum ossinho caísse na mesma figura ${ }^{346}$, prostrava-se, convencido de que ia conseguir concretizar o seu desejo. Mas se, pelo contrário - o que costuma acontecer —, tinha azar ao lançar os

${ }^{345}$ Não parece que as faces tivessem propriamente figuras, mas apenas os números; poderíamos antes traduzir por «se lhe saía o lance da própria deusa» (v. infra).

346 Neste jogo de dados (ossinhos de seis faces, mas só marcados em quatro), o lance da sorte era o chamado "de Afrodite» ou «de Vénus» (lat. Venus), que consistia na posição de quatro faces diferentes, com os números I, III, IV, VI; o lance pior era o chamado "dos cães» (lat. canis ou canicula), caso em que saíam os quatro ases: I, I, I, I. 
ossinhos sobre a mesa e estes mostravam uma composição de mau agoiro, amaldiçoava Cnido inteira, como se isso fosse uma desgraça irremediável, e ficava macambúzio; mas, logo a seguir, retomava os dados, a fim de, com outro lance, corrigir o azar anterior. Como a paixão o inflamasse cada vez mais, já todos os muros estavam cheios de inscriçóes, e já todas as tenras cascas de árvores proclamavam "AFRODITE É FORMOSA»" ${ }^{347}$. Dedicava a Praxíteles a mesma estima que a Zeus, e todo o objecto precioso e belo que guardava em sua casa, dava-o como oferta à deusa. Por fim, os seus ardentes acessos de paixão degeneraram em loucura, e a sua audácia revelou-se um incentivo do seu desejo. De facto, uma vez, ao pôr do sol, iludindo calmamente os presentes, esgueirou-se para trás da porta e, deixando-se ficar invisível na parte mais interior [da câmara], não se mexia e quase não respirava. Logo que as sacerdotisas auxiliares, como de costume, fecharam a porta do lado de fora, este novo Anquises $^{348}$ ficou trancado lá dentro. Mas para quê narrar-vos em pormenor, eu ou outra pessoa ${ }^{349}$, a audácia levada a cabo naquela noite infanda? De manhã, descobriram-se as marcas dos abraços eróticos, e a deusa apresentava a nódoa como prova do que tinha sofrido. Quanto ao jovem, segundo reza a versão popular, dizem que se atirou de uns rochedos ou nas ondas do mar, e que nunca mais se soube nada dele.

17. Ainda a sacerdotisa ajudante falava, e já Cáricles, no meio da narrativa, exclamava, dizendo: "Quer isto dizer que o género feminino, ainda que de pedra, se faz amar! Que não seria, se víssemos uma tamanha beldade animada de vida?! Não seria uma só destas noites preferivel ao ceptro de Zeus?» Então Calicrátidas, sorrindo, disse: "Ó Cáricles, ainda não sabemos se vamos ouvir contar muitas histórias deste género, quando estivermos em Téspias ${ }^{350}$. De momento, porém, esta história constitui uma prova evidente contra essa Afrodite que tu tanto enalteces.» Como Cáricles perguntasse "Como é isso?», Calicrátidas

${ }^{347}$ Este tipo de inscrição era habitual, quando se tratava de declarar uma paixão por mulher ou rapazinho; menos vulgar, naturalmente, se aplicado a uma deusa.

${ }^{348} \mathrm{O}$ autor compara o jovem a Anquises, um mortal que amou Afrodite, e de cuja relação nasceu Eneias.

${ }^{349}$ Segui a lição dos mss., que não parece muito convincente... mas as emendas modernas ainda me parecem mais difíceis de aceitar.

${ }^{350} \mathrm{~V}$. fim do $\$ 11$ e nota. 
respondeu-lhe de um modo, a meu ver, muito convincente: "Realmente — disse ele —, esse jovem apaixonado, com toda uma noite à sua disposição para ter a completa possibilidade de satisfazer a sua paixão, teve relaçóes com a pedra à maneira pedófila, pois é manifesto que náo quis nada com a parte feminina dianteira.» Então eu, pondo termo àquela confusa altercação feita de argumentos incoerentes e desordenados, disse: "Meus senhores e meus amigos: Tratai a questão com ordem, segundo a norma que convém a gente educada. Abstende-vos, pois, de uma discussão desordenada e que não teria fim, e exponde, cada um por sua vez, em separado, a sua opinião. Na verdade, ainda não é tempo de regressarmos ao navio. Aproveitemos então o tempo livre para nos divertirmos e nos entregarmos a um assunto sério, capaz de, juntamente com o prazer, nos ser de utilidade. Saiamos, pois, do templo - aonde está afluindo grande multidão, por motivos piedosos - e vamos reclinar-nos num dos locais das refeiçóes, a fim de escutarmos e dizermos, com toda a calma, o que muito bem entendermos. Lembrai-vos, porém, que aquele que hoje sair derrotado nunca mais nos deve incomodar sobre o mesmo assunto."

18. Eles acharam que eu tinha falado muito bem, pelo que, em vista da sua aprovaçáo, saímos [do templo], eu muito satisfeito, pois não tinha qualquer preocupação que me pressionasse, enquanto eles revolviam para consigo, no seu espírito, toca abaixo, toca acima, uma profunda meditação, como se fossem disputar o primeiro lugar no cortejo em Plateias ${ }^{351}$. Chegados a um local coberto e umbroso, próprio para repousar na estação do verão, falei: "Este sítio é agradável, pois no cimo das árvores cantam melodiosamente as cigarras.» Então, sentei-me entre ambos, com todo o ar de juiz e com a própria Helieia ${ }^{352}$ estampada nas sobrancelhas. Depois, tendo proposto a ambos tirar à sorte para se saber quem falaria em primeiro lugar, e tendo o sorteio

351 Todos os anos, no $16^{\circ}$ dia mês de Memactérion (M $\left.\alpha \imath \mu \alpha \kappa \tau \eta \rho \imath \omega ́ v\right)$, correspondente ao nosso mês de Novembro, se celebrava em Plateias, na Beócia, um cortejo fúnebre em honra dos gregos caídos na batalha de Plateias, contra os Persas (479 a.C.). Faz-se aqui alusão, não só ao lugar da frente ocupado no cortejo, mas também à honra de ser escolhido para pronunciar a oração fúnebre.

${ }^{352}$ Praça de Atenas, onde funcionava um dos tribunais; por extensão, esse mesmo tribunal, de que faziam parte 6000 cidadãos-juízes, heliastas ( $\dot{\eta} \lambda 1 \alpha \sigma$ $\tau \alpha$ í) maiores de 30 anos, tirados à sorte e repartidos por 10 secções de 500 membros; os 1000 lugares restantes eram lugares de reserva para cobrir faltas. 
designado em primeiro lugar Cáricles, ordenei-lhe que desse imediatamente início ao discurso.

19. Então ele coçou o rosto com a mão direita, ficou um momento em silêncio, e começou mais ou menos nestes termos:

"A Ti, Senhora Afrodite, a Ti as minhas preces invocam para que me assistas neste discurso em tua defesa. Sim, se toda e qualquer obra sairá perfeitissima, desde que tu lhe insufles nem que seja só um pouco daquela persuasão que te é própria, são os discursos eróticos aqueles que mais necessitam da tua ajuda, pois tu és a sua mais autêntica mãe. Vem, sim, como advogada feminina das mulheres, mas também concede aos homens a graça de permanecerem machos, tal como foram gerados. E logo no começo do meu discurso, invoco, como testemunha das ideias que defendo, a mãe primordial e raiz primeira de toda a criação, ou seja, a santa natureza do Todo-Universal, a qual, ao fixar os primeiros elementos do Universo - terra, ar, fogo e água —, através da mistura de uns com os outros, insuflou vida e alma a tudo o que existe. Essa natureza, sabendo que nós somos criaturas de matéria mortal, e que a cada um de nós foi distribuido um breve tempo de vida, preparou as coisas de modo que à decomposição de um correspondesse a geração de outro, e para cada um que morria contou com um a ser gerado, a fim de que, por esta sucessão de uns aos outros, vivêssemos até à eternidade. Como, porém, era impossivel que de um só ser nascesse algo, imaginou para cada ser uma dupla natureza: ao conceder aos machos a propriedade exclusiva de verter esperma, e ao fazer da fêmea como que o receptáculo da semente, insuflando, portanto, em ambos os sexos um desejo comum, uniu-os um ao outro, prescrevendo a cada um que, obedecendo ao sagrado laço da necessidade, permanecesse fiel à sua natureza especifica, e que nem a fêmea se masculinizasse contra a natureza, nem o macho se feminizasse indecorosamente. É assim que as relaçóes de homens com mulheres têm, até hoje, e por sucessöes imortais, conservado a raça humana. Nenhum homem pode gabar-se de ter sido gerado por obra de um só homem, mas antes todas as honras são devidas a dois nomes venerandos, pelo que prestamos culto à mãe em pé de igualdade com o pai.

20. Ora, no princípio, quando a humanidade 353 ainda pensava à maneira dos heróis e venerava a virtude que coabitava com os deuses, o homem obedecia aos ditames instituidos pela natureza e, unindo-se a

353 O texto diz "a vida», entenda-se "... dos homens», «... humana», ou "a sociedade»; esta palavra é o sujeito, simultaneamente, de "pensava» e «obedecia», mas. por clareza, especifiquei o sujeito do $2^{\circ}$ verbo. 
mulheres em idade adequada, tornavam-se pais de nobres filhos. A pouco e pouco, porém, a sociedade, decaindo dessa grandeza e precipitando-se $e^{354}$ no abismo da luxúria, foi traçando estranhas maneiras de prolongar os prazeres. Depois, a luxúria que tudo ousa violou a própria natureza. Quem terá sido o primeiro que olhou para um macho como se fosse uma fêmea, quer violando-o tiranicamente, quer persuadindo-o manhosamente? Num único leito entrou uma única natureza. Olhando-se uns aos outros, não tinham pejo nem do que faziam nem do que suportavam ${ }^{355}$, mas, como sói dizer-se, semeando sobre pedras estéreis, compraram por um pequeno prazer uma grande desonra.

21. Alguns levaram mesmo a ousadia a um ponto tal de violência tirânica, que chegaram a violar a natureza servindo-se de uma faca ${ }^{356}$ : tirando o sexo aos machos, acharam maneira de prolongar o prazer; e os infelizes e desventurados, só para permanecerem meninos mais tempo, nem sequer chegam a homens feitos - ambiguo enigma de dupla natureza -, sem conservarem aquele sexo no qual nasceram e sem possuirem aquele em que se transformaram. A flor que haviam conservado na juventude murchou numa velhice prematura. De facto, contam-se entre os meninos, mas envelheceram sem terem de permeio nada de homens feitos ${ }^{357}$. Deste modo, a maldita luxúria, mestra de todo o mal, imaginando despudorados prazeres, uns atrás dos outros, rebaixou-se a um ponto tal, que, por decência, não é possivel aqui explicitar, para não omitir nenhuma espécie de torpeza.

22. Ora, se cada um de nós se conformasse com as leis que a providência nos prescreveu, contentar-nos-iamos em ter relaçóes com mulheres, e a nossa vida seria limpa de infâmia. É óbvio que mesmo entre os animais, incapazes, pese embora a sua má indole, de adulterar seja o que for, as leis naturais são preservadas na sua pureza. Os leóes não ficam loucos de desejo por leóes, mas Afrodite, em seu devido tempo, suscita-lhes o apetite pela fêmea; o touro, rei da manada, cobre as vacas, e o carneiro enche todo o rebanho de semente masculina.

${ }^{354} \mathrm{O}$ texto tem só um predicado: «decaindo dessa grandeza para o abismo da luxúria...».

355 Trata-se, como é óbvio, do papel desempenhado por cada um dos intervenientes, num papel activo ou passivo.

${ }^{356} \mathrm{O}$ texto diz «com um ferro», $\sigma \imath \delta$ ń $\rho \omega \imath$ que pode ser uma designação genérica, "qualquer objecto de ferro», p. ex. "espada», "ponta de flecha», "machado», "foice», "anzol», ou, como aqui, "faca» (espécie de bisturi).

${ }^{357}$ A ideia poderia exprimir-se mais naturalmente por «... envelheceram sem ter passado pela idade madura». 
Que mais? Não se lançam os javalis no covil das javalinas? E os lobos não copulam com as lobas? Numa palavra, nem as aves que sulcam os ares, nem aquelas criaturas às quais coube em sorte o elemento líquido, nem qualquer animal terrestre, nenhum deles procura uma relação com um macho, mas, pelo contrário, permanecem imutáveis os decretos da providência. Vós, porém, que sois louvados, aliás injustamente, pelo vosso bom senso, vós, animais verdadeiramente despreziveis, vós, homens, por que estranho mal violais a natureza e vos incitais a degradar-vos mutuamente? Que cega insensibilidade de alma é essa que, vertida sobre vós, vos faz pecar duplamente, quer fugindo daquilo que devieis procurar, quer procurando aquilo de que devieis fugir? Ora, se todos, tomando um só por exemplo, optassem por imitar tais actos, não existiria sequer uma única pessoa.

23. Neste ponto, porém, surge da parte dos socráticos um argumento espantoso, pelo qual sáo enganados os ouvidos dos jovens, ainda carentes de raciocinios perfeitos; mas quem tem o raciocinio bem desenvolvido não é susceptivel de deixar-se seduzir. De facto, fingem ter amor à alma e, envergonhando-se de amar a beleza do corpo, denominam-se a si próprios amantes da virtude, coisa que muitas vezes me faz rebentar de riso. Que é que se passa convosco, veneráveis filósofos, que, por um lado, desprezais com a vossa indiferença uma pessoa que, ao longo de muitos anos, já deu provas da sua qualidade, cujos cabelos encanecidos e cuja velhice atestam a sua virtude, mas, por outro lado, todo a vossa erudita paixão se incendeia por um desses jovens que ainda náo possuem no seu espirito a capacidade de julgar sobre o caminho a seguir? Ou será que existe alguma lei que diga que toda a deformidade deve ser condenada como perversidade, enquanto o belo deve ser louvado como sendo bom? No entanto, segundo Homero, esse grande profeta da verdade ${ }^{358}$,

Um homem pode ter, por natureza, | no seu aspecto pouca formosura, mas dá-lhe a divindade, nas palavras, a graça; e para ele os outros homens, olhando extasiados, se comprazem; | e ei-lo que discursa afoitamente, mas com doce modéstia no gesto; | distingue-se da massa popular, e ao passar na alta da cidade, | as gentes o contemplam como um deus.

358 Od., VIII, 169-173. Note-se que a tradução se apresenta em versos de $10+10$ sílabas, separados por uma cesura. Também poderíamos (v. $\$ 2$, dois exs.) verter por $7+7$ sílabas. Em qualquer dos casos, não há (e julgo que não poderia haver) correspondência métrica com o hexâmetro dactílico... 
E também disse algures ${ }^{359}$ :

... em ti não se acrescentam | os dons de inteligência à formosura.

Realmente, o sábio Ulisses é mais elogiado que o formoso Nireu ${ }^{360}$.

24. Então porque é que não vos ocorre nenhuma paixão pela sabedoria, pela justiça e pelas demais virtudes que têm o seu lugar concentrado em homens maduros, enquanto a formosura dos rapazinhos desperta em vós os mais agudos acessos de paixão? Nesta ordem de ideias, ó Platão, devíamos amar Fedro, apesar de Lisias, que aquele traiu?! Ou seria natural amar a virtude de Alcibiades, apesar de ele ter mutilado as estátuas de deuses ${ }^{361}$ ou a sua voz, num acesso de embriaguez, ter parodiado os mistérios iniciáticos de Elêusis?! Quem confessará ter sido seu apaixonado, depois de Atenas ter sido traida, depois de Decelia ter sido fortificada e quando o seu modo de vida aspirava à tirania? Ora, segundo o divino Platão, enquanto ainda não tinha barba na cara, Alcibiades era amado por todos, mas, após passar da meninice para a idade adulta, na idade em que o seu espirito, até entâo imaturo, adquiriu a plena capacidade intelectual, era odiado por toda a gente. Pois quê?! Ao imporem nomes honestos a paixôes vergonhosas, chamam virtude da alma à beleza do corpo, esses... "pedó-filos», mais do que... «filó-sofos»" ${ }^{362}$. Mas, para

${ }^{359}$ Od., XVII, 454. O texto citado omite, por desnecessário, o $1^{\circ}$ pé; o $1^{\circ}$ hemistíquio completo diria, pois, Ó desgraçado, em ti não se acrescentam...

${ }^{360}$ Nireu era, depois de Aquiles, o mais formoso dos Gregos. Ora, o verso acima citado pertence a uma fala de Ulisses dirigida a Antínoo, um dos pretendentes de sua esposa Penélope, e que certamente seria um garboso jovem. O autor desta obra (Pseudo-Luciano) não só cita de cor ("disse algures...»), como parece referir a Nireu o verso citado.

361 Alcibíades, ateniense da alta aristocracia, educado por Péricles e grande amigo de Sócrates, era célebre pela sua beleza, pelo seu talento, mas também pela sua truculência iconoclasta. Neste passo, faz-se referência á mutilação das estátuas de Hermes, à paródia e revelação dos mistérios de Elêusis, ao facto de, refugiado em Esparta, ter induzido os Espartanos a erguer uma fortaleza no demo ático de Dicelia e, finalmente, ao seu espírito conspirativo, que pretendia instaurar a tirania em Atenas. Todos estes actos, segundo o raciocínio propositadamente absurdo de Cáricles, seriam simplesmente relevados, atendendo á formosura da pessoa.

${ }^{362} \mathrm{O}$ texto grego joga com os compostos philóneoi ( $\varphi \imath \lambda$ óvعol) «amantes

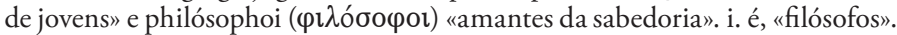
Embora possamos manter o elemento filo-, não nos pareceu aceitável inven-tar um palavrão como *filó-neos, a jogar com filó-sofos. Notar que em grego existe, 
não darmos a impressão de que é por má vontade que evocamos estes factos a respeito de varóes ilustres, baste o que ficou dito.

25. Mas agora, Calicrátidas, afastando-me um pouco do meu plano específico, e descendo ao vosso tipo de prazer, vou provar que a relaçâo com mulheres é muito melhor que a relaçáo com rapazes. Em primeiro lugar, considero que todo e qualquer prazer é tanto mais agradável, quanto mais tempo durar. De facto, um prazer rápido passa voando e acaba antes que o tenhas experimentado todo, enquanto o deleite prolongado é bem melhor. Oxalá a avarenta Moira nos tenha fiado uma longa duração de vida, toda ela plena de saúde e sem qualquer dor a devorar-nos o espirito! Assim, passaríamos todo o nosso tempo de vida em festas e celebraçóes. Uma vez, porém, que a invejosa divindade teve má vontade em nos conceder os maiores bens, entre os bens actuais são mais agradáveis aqueles que mais tempo duram. Ora, uma mulher, desde rapariga até à meia idade, antes que as última rugas da velhice lhe cubram completamente a face, é uma companheira digna de ser abraçada pelos homens, e, embora já passada da juventude, mesmo assim

\section{... a sua experiência}

tem algo pra dizer $\mid$ mais sábio que a dos jovens. ${ }^{363}$

26. Mas um homem que tente uma relação com um jovem de vinte anos, parece-me a mim que sofre de uma paixáo impura, ao perseguir uma Afrodite equivoca. De facto, as massas musculares dos seus membros já adultos tornam-se duras, e o queixo, coberto de espessa barba, fica áspero, em vez de macio como antes, e as coxas ficam eriçadas de pêlos, como se estivessem sujas. E quanto às partes recatadas, deixo o seu conhecimento para vós, que já tendes experiência delas. Numa mulher, pelo contrário, brilha sempre, em toda ela, a graça da coloraçáo da sua pele, e da sua cabeça pendem fartas madeixas em caracol, cor de púrpura, semelhantes na sua beleza a jacintos em flor ${ }^{364}$, umas escorrendo pelo dorso e embelezando os ombros, e outras descendo pelas orelhas

a par de paidó-philos ( $\pi \alpha \imath \delta$ ó- $\varphi \imath \lambda \mathrm{o} \varsigma)$, e com o mesmo sentido, philó-pais, -paid- ( $\varphi \imath \lambda o ́-\pi \alpha \imath \varsigma,-\pi \alpha \imath \delta$-), mas o português, neste caso, não permite fazer a transposição, o que daria (com problemas de adaptação!)... *filopedo (!!!).

363 Eurípides, Fenícias, 529-530.

364 «... da sua cabeça... etc.»: paráfrase da Odisseia, VI, 230-231, onde se diz, mas a respeito de Ulisses, que Atena «da cabeça lhe fez crescer uma cabeleira frisada, semelhante á flor do jacinto». 
e pela fronte, muito mais encaracoladas que o aipo dos prados. E todo o resto do seu corpo, sem lhes ter despontado sequer um pêlo, "resplandece", como sói dizer-se, "mais brilhante que o âmbar ou que o cristal de Sidon"365.

27. Mas... porque é que, de entre os prazeres, não havemos de procurar os que são reciprocos, aqueles que deleitam tanto os participantes activos como os passivos? De facto, e diferentemente dos animais irracionais, nós, humanos, não nos comprazemos com a vida solitária, mas, pelo contrário, estreitamente ligados a uma comunidade de amigos, consideramos as coisas boas ainda mais agradáveis, quando mutuamente compartilhadas, e as penosas mais fáceis de suportar em conjunto com outros. Foi dai que se inventou a mesa comum: ao institui-la como centro intermediário da amizade, atribuimos ao estômago o prazer que lhe é devido, pois, por exemplo, não bebemos sem companhia o vinho de Tasos, nem nos enchemos, sós connosco mesmos, de comidas requintadas, pois todos nós as achamos mais agradáveis na companhia de outra pessoa; do mesmo modo, ao partilharmos os prazeres sexuais, ainda mais nos deliciamos. Ora, as relaçóes com mulheres proporcionam uma troca de prazer idêntica: tendo-se entregue um ao outro, retiram-se satisfeitos por igual... a menos que atentemos na opinião de Tirésias, segundo o qual o gozo da mulher é duas vezes superior ao do homem. Julgo que é decente que os homens não queiram gozar de maneira egoista e que não visem retirar sozinhos algum benefício, recebendo todo o gozo da outra parte, mas sim que, compartilhando o prazer de que gozam, o retribuam da mesma maneira. Ora, isto é algo que ninguém poderia dizer a respeito da relação com rapazes, pois náo seria louco a esse ponto, já que o participante activo, depois de gozar - assim o crê - de um prazer extraordinário, retira-se, enquanto para o ultrajado ficam, de começo, as dores e as lágrimas, e embora, com o passar do tempo, o sofrimento físico se vá atenuando e já não the causes incómodo, prazer é coisa que náo sente. Mas, se podemos falar mais explicitamente - e certamente que podemos, no recinto de Afrodite -, também é possivel, Calicrátidas, servirmo-nos de uma mulher como de um rapazinho, conseguindo uma dupla via para o prazer, ao passo que um rapaz não proporciona, de maneira nenhuma, o gozo que uma mulher oferece.

365 Sídon, cidade da Fenícia, de grande actividade comercial, célebre pelas indústrias da tinturaria e do vidro. 
28. Portanto, se uma mulher também é susceptivel de vos ${ }^{366}$ satisfazer, nós, homens, devemos abster-nos de ter relaçôes uns com os outros; se, porém, as relaçóes de machos com machos são consideradas decentes, que também as mulheres, de hoje em diante, se amem umas às outras. Vamos, pois, ó homem da nova geração e legislador de estranhos prazeres, depois de teres imaginado novos caminhos para as volúpias do macho, reconhece às mulheres a mesma faculdade, e que elas tenham relaçóes umas com as outras, tal como os homens! Que elas, depois de fixarem no baixo ventre um órgão postiço de devassidão, esse monstruoso instrumento desprovido de semente, se deitem, mulher com mulher, como faz o homem. Então, que essa palavra, que raramente chega aos nossos ouvidos, palavra referida à obscenidade das tríbades ${ }^{367}$ - sinto pudor só de pronunciá-la - triunfe por completo; que todos os nossos gineceus sejam como o de Filénide, que se desonram com relaçôes sexuais andróginas. Mesmo assim, quanto melhor não seria que uma mulher forçasse a sua luxúria fazendo de macho, do que a nobre raça dos homens efeminar-se, fazendo de mulher!»

29. Tendo pronunciado este discurso com veemência e paixão, Cáricles calou-se, lançando à sua volta um olhar terrível e feroz; deu-me mesmo a impressão de que estava a executar um ritual de purificação contra a relação sexual com meninos. Então eu, sorrindo tranquilamente e voltando calmamente o olhar para o ateniense, disse: "Ó Calicrátidas, eu esperava que, ao sentar-me aqui, seria juiz de uma causa para brincar e para rir, mas, não sei lá como, fui levado pela veemência de Cáricles para uma tarefa mais séria. De facto, ele excitou-se demasiadamente, quase tanto como se estivesse no Areópago a defender-se de uma acusação de assassinio, de fogo posto, ou, por Zeus!', de envenenamento. Esta ocasião requer, mais do que nunca, que tu, num único discurso, utilizes toda a

366 «vos» é um plural majestático, equivalente a «te», referido a Calicrátidas; mas também pode referir-se a todos os homens com gostos pedófilos.

367 Tríbades ( $\tau \rho \imath \beta \alpha ́ \delta \varepsilon \varsigma$ ) era a designação dada a mulheres que tinham relaçóes sexuais com outras mulheres, numa participação sobretudo activa, e furiosa, fazendo o papel de macho; o termo «lésbica» traduz razoavelmente a ideia, mas os dicionários não registam * $\lambda \varepsilon \sigma \beta \imath \kappa \eta ́$, «lésbica», e o outro adjectivo, $\Lambda \varepsilon \sigma \beta \imath$ เ , fem. $\Lambda \varepsilon \sigma \beta i \alpha$, tem o sentido de «natural de Lesbos»; no entanto, a ideia de "(mulher) lésbica» já devia ser possível,

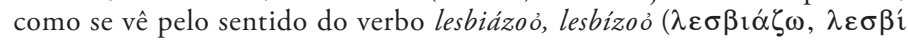
$\zeta \omega)$, "praticar deboche como as (mulheres) de Lesbos". cf. Aristf., Rãs, 1308, Vespas, 1346, e o próprio Luciano, Pseud., 28. 
oratória ateniense, o poder de persuasão de Péricles e as linguas dos dez oradores armadas contra os Macedónios, que, enfim, evoques uma das declamaçóes públicas pronunciadas na Pnix ${ }^{368}$.»

30. Então Calicrátidas, após um breve silêncio, em que, pela sua expressão, me pareceu dominado pela inquietação, deu início ao seu discurso de resposta:

"Se as mulheres tivessem o poder de participar na Assembleia do Povo, nos tribunais e na coisa pública, tu, Cáricles, já terias sido aclamado como general ou seu protector, e te honrariam com estátuas de bronze nas praças. De facto, se lhes fosse conferido o poder de discursar, nem sequer aquelas que, de entre todas elas, são consideradas eximias em termos de cultura falariam com tanta competência como tu: nem Telesila ${ }^{369}$, armada contra as espartanas, e devido à qual, em Argos, Ares é tido como $o$ deus das mulheres; nem Safo, o doce orgulho dos lésbios; nem Teano, filha do sábio Pitágoras; talvez nem mesmo Péricles falasse assim tão bem em defesa de Aspásia. Ora, já que fica bem que os homens falem em defesa das mulheres, falemos também nós, homens, em defesa dos homens. E tu, Afrodite, sê-nos propicia, pois nós veneramos o teu filho Eros."

31. Ora bem: Antes de mais, eu julgava que a nossa alegre discussão se desenvolveria dentro dos limites da brincadeira. Como, porém, as palavras aqui do meu adversário foram pensadas em termos filosóficos em defesa das mulheres, aproveito de bom grado a ocasião [de fazer o mesmo]. Realmente, a relação sexual entre machos é a unica actividade que comunga simultaneamente do prazer e da virtude. Sim, quem me dera, se isso fosse possivel, que nascesse e se elevasse já aqui, junto de nós, o plátano que outrora escutou as palavras socráticas, árvore mais venturosa que a Academia ou o Liceu, à sombra da qual Fedro costumava reclinar-se, como disse esse santo homem tocado por muitissimas graças ${ }^{370}$. Talvez essa árvore, tal como o carvalho de Dodona, fizesse ressoar de dentro dos seus ramos uma voz sagrada e abençoasse os amores com rapazes, ainda recordada do formoso Fedro. Embora, porém, isso seja impossivel,

${ }^{368}$ A Pnix era um largo em hemiciclo, de $70 \times 120 \mathrm{~m}$, murado, a Oeste da Acrópole, onde se reunia o povo em ocasióes solenes ou graves.

369 Poetisa de Argos (séc. V a. C.), armou e comandou as mulheres da sua cidade contra o exército espartano comandado pelo seu rei Cleómenes.

$370 \mathrm{O}$ «santo homem» é Platão; quanto ao plátano e à personagem a que se faz referência, v. Platão, Fedro, 229b 
| que há muita coisa entre nós:

as montanhas ensombradas, | e o sussurrante mar, ${ }^{371}$

e embora sejamos estrangeiros abandonados ${ }^{372}$ em terra estranha, e embora Cnido constitua uma vantagem em favor de Cáricles, mesmo assim não me darei cobardemente por vencido e não trairei a verdade.

32. Que tu, divindade celestial, em boa hora venhas em meu auxílio, tu, divindade propicia à amizade, tu, hierofante ${ }^{373}$ dos mistérios, tu Eros, não esse menino perverso que as mãos dos pintores se divertem a representar, mas sim aquele que o principio universal primeiro gerou, adulto logo ao nascer ${ }^{374}$. Foste tu que deste forma ao Universo, tirando-o da sua negra e confusa disformidade. Como se tivesses removido a pedra sepulcral de todo o mundo, escorraçaste aquele Caos que o envolvia, enviando-o para as mais remotas profundezas do Tártaro,

onde os portóes são de ferro | e o limiar é de bronze,

de tal modo, que, agrilhoado num cárcere indestrutivel, the seja vedado o caminho de regresso. Depois, rasgando a noite escura com teu brilhante facho, tornaste-te o demiurgo de tudo o que é inanimado e de tudo o que tem alma. Instilando nos homens uma concórdia excelente, uniste neles o nobre sentimento da amizade, para que, alimentados em conjunto, os bons sentimentos, que eram os de uma alma ainda ingénua e delicada, amadureçam até à perfeição.

33. Realmente, e antes de mais, o casamento foi inventado como solução para a necessária perpetuação da espécie, mas só o amor masculino constitui um belo mandamento para o espirito do filósofo. Ora, a todas as coisas à nossa volta, quando trabalhadas a fim de parecerem bem, dá-se mais valor do que àquelas que se ligam a um

371 Iliada, I, 156-157. Notar a apresentação da versão em versos de 7 sílabas separados por uma cesura: $7+7$.

372 É óbvio que se trata do chamado "plural majestático".

373 Sacerdote que presidia aos mistérios, ou o seu fundador.

${ }^{374}$ De facto, os gregos tinham duas representaçóes (ideias, conceitos) da divindade a que chamavam Eros ("E terceiro mais antigo, logo a seguir ao difuso Caos (Xóos) e à Terra, Gaia $(\Gamma \alpha \hat{\imath} \alpha)$; e o deus menino, traquinas, que se entretinha a lançar setas ao peito de deuses e humanos. 
uso imediato, e, seja como for, o belo é superior ao necessário. Ora, enquanto os homens eram ignorantes e ainda náo tinham tempo disponivel para passar da vivência do dia-a-dia para algo melhor, contentavam-se razoavelmente com o necessário, pois a premência do tempo não lhes permitia procurar uma vida boa. Quando, porém, as prementes necessidades tiveram fim, os pensamentos das geraçóes seguintes, libertos da necessidade, passaram a ter tempo para imaginar algo de melhor, e assim a pouco e pouco, foram-se desenvolvendo os conhecimentos, facto que nos é possivel conjecturar com base nas artes mais desenvolvidas. Logo os primeiros homens existentes procuravam resolver o problema da fome diária; então, pressionados pela necessidade imediata, e uma vez que a indigência não lhes permitia escolher o que fosse melhor, alimentavam-se da primeira erva que encontravam, desenterrando raizes tenras ou, a maior parte das vezes, comendo o fruto do carvalho ${ }^{375}$. Mas, passado algum tempo, este tipo de alimentação foi deixado para os animais irracionais, e as preocupaçóes dos agricultores viraram-se para a semente do trigo e da cevada, que descobriram que deviam renová-la todos os anos. Eninguém seria tão louco, que dissesse que a glande do carvalho é melhor que a espiga.

34. Pois quêe? Não é verdade que, logo no princípio da vida humana, os homens, precisando de se cobrir, esfolaram animais e se cobriram com as suas peles? E não imaginaram utilizar cavernas das montanhas e cavidades ressequidas de velhas raizes ou plantas como refúgio contra o frio? Com base nisso, e orientando a imitaçâo no sentido da perfeição, teceram mantos para seu uso, construíram habitaçöes e, insensivelmente, as respectivas técnicas, tomando o tempo como mestre, produziram, em vez de um tecido simples, belos bordados; em vez de humildes choupanas, conceberam altos tectos em mármore sumptuoso, e pintaram a nua fealdade das paredes com tintas de cores garridas. Ora, cada uma destas artes e ciências, destinadas ao silêncio e votadas a um profundo esquecimento, despontaram, pouco a pouco, e como de um longo ocaso, até atingiram o brilho que lhes é próprio. De facto, cada pessoa, ao inventar algo, transmitia-o ao seu sucessor; depois, a sucessão dos que iam recebendo, já acrescentada com aquilo que haviam aprendido, acabou por completar as deficiências.

${ }^{375}$ Os comentadores explicam que se trata de certa espécie de carvalho (Quercus Aegilops), que dá glandes comestíveis; também poderíamos pensar, simplesmente, na azinheira e no respectivo fruto, as bolotas. 
35. Que ninguém pretenda encontrar, nos tempos antigos, relaçóes sexuais [de machos] com machos, pois as relaçóes com mulheres eram coisa absolutamente necessária, a fim de que a nossa raça, por falta de semente, não desaparecesse por completo. Mas a variedade dos conhecimentos, bem como o nosso desejo daquela virtude amante da beleza, começaram a vir lentamente à superfície, por acção do tempo, que não deixa nada por explorar, de modo que, juntamente com a divina filosofia, também a pederastia atingiu o auge. Nunca mais condenes, ó Cáricles, nem consideres como sendo mau aquilo que não foi inventado logo de inicio; e lá pelo facto de as relaçóes com mulheres serem atribuidas a um tempo mais antigo do que as relaçóes com rapazes, não inferiorizes estas, mas antes consideremos os hábitos mais antigos como sendo obra da necessidade, ao passo que os procedimentos que a vida ociosa inventou devem ser considerados superiores àqueles.

36. Ainda há pouco me deu uma grande vontade de rir, enquanto Cáricles gabava os animais irracionais e a vida solitária dos Citios ${ }^{376}$ : pouco faltou para que, levado pelo entusiasmo, se arrependesse de ser grego. Eé que nem sequer disfarçou o seu discurso num tom de voz moderado, como faria quem perorasse precisamente contra a tese que tentava defender, mas, pelo contrário, gritava a plenos pulmóes: 'Os leóes, os ursos, os javalis ${ }^{377}$ não têm relaçóes uns com os outros, mas domina-os apenas o seu próprio impulso dirigido às fêmeas'. Que é que isso tem de admirável? Realmente, aquilo que se pode judiciosamente escolher com base no raciocinio, é coisa que os seres incapazes de raciocinar, precisamente por falta de razão, não podem alcançar. De facto, se Prometeu ou qualquer outro deus tivesse dotado os animais com a inteligência humana, eles não levariam uma vida solitária nas montanhas, nem se comeriam uns aos outros, mas antes, tal como nós, erigiriam templos, habitaria cada um o seu próprio lar e viveriam como cidadãos governados por leis comuns. Que tem de extraordinário que os animais, condenados pela natureza a náo receber $d a$ Providência nenhum dos privilégios que a razáo proporciona, se vejam privados, entre outras coisas, da paixão por outros machos? Os leóes não têm tais relaçôes, pois não filosofam; os ursos não têm

${ }^{376}$ Esta alusão não está explícita no discurso de Cáricles. V. \ 27.

${ }^{377}$ No $\$ 22$, Cáricles náo refere os ursos, mas os leóes, os touros, os carneiros, os javalis, os lobos e as aves e os peixes em geral. É claro que, do ponto de vista da argumentação, esta imprecisão não tem qualquer gravidade; do mesmo modo, a citação, feita de cor, é fiel somente em relação à ideia geral. 
tais relaçôes, pois não conhecem a beleza da amizade. No caso dos homens, porém, a inteligência, acompanhada da ciência e à força de frequente experimentação, escolheu o melhor de tudo e considerou que a relação entre machos era a mais estável.

37. Portanto, Cáricles, não nos venhas para cá com histórias de cortesãs de vida depravada, não insultes a nossa dignidade com esse teu discurso ligeiro nem confundas o Eros Celeste com o [Eros] Menino, mas antes reflecte (embora, na tua idade, já seja tarde para desaprender ${ }^{378}$ ), em todo o caso, reflecte, agora mesmo (já que não o fizeste antes), que há dois deuses com o nome de Eros, que não trilham o mesmo caminho nem incendeiam as nossas almas com o mesmo sopro, mas, pelo contrário, um deles, como se - julgo eu - tivesse uma mentalidade completamente infantil e não possuisse um raciocinio capaz de dominar a inteligência, concentra-se em força nos espiritos dos insensatos e interessam-lhe sobretudo as paixóes por mulheres. Esse Eros é o companheiro da impetuosidade efémera, que, numa precipitação irreflectida, arrasta os homens para o objecto do seu desejo. O outro Eros, porém, patriarca dos tempos ogígios ${ }^{379}$, de aspecto venerando, de imagem sagrada e dispensador de sentimentos moderados, sopra docemente nas almas de cada pessoa, e, se esta divindade nos calhar ser propicia, gozamos de um prazer misturado com virtude. Na verdade, segundo o poeta trágico ${ }^{380}$, Eros sopra com dois sopros e, sob um único nome, abrange paixóes nada semelhantes. Na verdade, Vergonha ${ }^{381} e ́$ uma divindade ambigua, ao mesmo tempo útil e perniciosa:

Vergonha, que grandemente | os homens perde ou ajuda;

Não há um género só | de Disputa sobre a terra, mas são duas: uma delas | o bom senso a louvaria; a outra é de censurar: | têm indoles opostas.

Portanto, não é nada de estranhar que o "páthos", a paixão, tenha a mesma designação dada à "aretề, a virtude, a ponto de se chamar "éros", amor, tanto ao prazer desregrado, como ao afecto sóbrio.

${ }^{378} \mathrm{O}$ verbo $\mu \varepsilon \tau \alpha \mu \alpha \nu \theta \alpha \dot{v} \omega$ significa, propriamente, "aprender depois», "aprender outra coisa».

379 «Tempos ogígios», ou «... de Ógigo», rei primitivo do tempo dos titãs, dos primeiros tempos da formação do Universo. Segundo Hesíodo, Eros é o deus mais antigo, a seguir ao Caos e à Noite.

${ }^{380}$ Não é possível identificar o poeta, mas tem-se sugerido Eurípides.

381 Em grego, Aidô (Aı $\delta \omega ́)$, fem., «Pudor». «Pudicícia»...; o termo «vergonha» parece, neste contexto, ser o correspondente menos mau. 
38. "Achas então" [- dir-me-ias - "que o casamento não vale nada e que deves afastar da tua vida as mulheres? E como é que nós, humanos, sobreviveriamos?" Seria desejável, segundo o sapientissimo Euripides ${ }^{382}$, que, libertos do contacto com mulheres, nos deslocássemos aos santuários e aos templos e ai comprássemos com prata e ouro os filhos para a nossa sucessáo. Na verdade, porém, a necessidade, ao impor-nos um pesado jugo no pescoço, força-nos a obedecer às suas ordens. Prefiramos, pois, segundo a nossa razáo, o que é belo, mas que a nossa utilidade ceda perante a necessidade. Que as mulheres contem, na medida em que nos dão filhos, mas, quanto ao resto, fora! Deus nos livre! Sim, que homem, no seu juizo perfeito, poderia suportar, logo desde a manhã, uma mulher a embelezar-se com expedientes artificiais, ela, cuja forma verdadeira é desgraciosa, mas a quem adornos estranhos corrigem a fealdade natural?

39. Ora, se uma pessoa visse uma mulher, logo de manhã, mal saida do leito nocturno, julgá-la-ia mais feia que aqueles animais cujo nome é de mau augúrio pronunciar em hora matinal ${ }^{383}$. É precisamente por isso que elas se trancam nos seus quartos, sem serem vistas por nenhum macho. Uma multidão de velhas e criadas tão feias como elas $^{384}$ andam à sua volta, tratando afanosamente com variadas drogas os seus infelizes rostos. Na verdade, não é depois de se lavarem e de sacudirem ${ }^{385} \mathrm{com}$ a pura corrente de água o torpor nocturno, que elas se entregam a sério a qualquer tarefa, mas são as numerosas composiçóes de pós que fazem brilhar o seu desagradável rosto; em fila como numa procissáo pública, cada uma das criadas tem na mão um objecto: bacias de prata, jarros, espelhos, uma enorme quantidade de caixinhas, como nos droguistas, potes com grande variedade desses malditos cremes $^{386}$, nos quais estão patentes ${ }^{387}$ a capacidade de branquear os dentes e a arte de escurecer as pálpebras.

${ }^{382}$ V. Hipólito, 618, ss.

${ }^{383}$ Referência ao macaco... ou macaca... ou mona...

${ }^{384} \mathrm{O}$ texto diz "com a mesma forma (física)».

385 "se lavam e sacodem»: o texto exprime estas duas ideias com um composto: $\alpha \dot{\pi} 0-v \imath \psi \alpha ́ \alpha \mu \varepsilon \alpha \imath$. V. também $\$ 44$.

${ }^{386} \mathrm{O}$ texto diz "vasos (ou potes) cheios de muita maldição", entenda-se - creio eu - ... para os homens, que se deixam seduzir por tantos artifícios. Em todo o caso, este passo (que prossegue) mostra o que seria a toilette das senhoras finas (e também das outras, na medida do possível).

${ }^{387}$ Alguns editores vão atrás de uma emenda já antiga e propóem «estão entesourados», aliás, no singular $(\theta \eta \sigma \alpha v \rho i ́ \zeta \varepsilon \tau \alpha \imath)$, a concordar normalmente 
40. O que, porém, demora a maior parte do tempo é o tratamento ${ }^{388}$ do cabelo. Algumas, por meio de loçóes capazes de dar às madeixas uma cor ruiva como a do sol do meio-dia, tingem-nas de um tom loiro, como se fosse lä, renegando a sua cor natural; aquelas que acham que uma cabeleira negra lhes fica bem, gastam com ela a fortuna dos maridos ${ }^{389}$, exalando dos cabelos quase toda a Arábia ${ }^{390}$; instrumentos de ferro, levemente aquecidos a uma fraca chama, frisam à força as ondas dos caracóis; uns cabelos, cuidadosamente conduzidos até às sobrancelhas, deixam à fronte um espaço muito estreito, enquanto os caracóis traseiros esvoaçam soltos pelas costas.

41. Depois disto, pöem ${ }^{391}$ uns sapatinhos pintados às florinhas, que apertam os pés até penetrarem na carne, e um finissimo véu a fingir de vestido, para darem a impressáo de estarem nuas ${ }^{392}$. Por debaixo do vestido vê-se tudo com mais nitidez que o próprio rosto, com excepção dos seios inesteticamente descaidos, que elas mantêm sempre ligados, como prisioneiros. Para quê descrever os seus caríssimos e ruinosos objectos? Por exemplo, as pedras da Eritreia pendentes das suas orelhas ${ }^{393}$, um fardo de muitos talentos ${ }^{394}$; ou as serpentes à volta dos seus pulsos ou dos seus braços (oxalá antes fossem serpentes verdadeiras, em vez de serem de ouro!); ou, à volta da cabeça, em constelação brilhantissima, uma coroa de pedras indianas; luxuosos colares pendem-lhes do pescoço; o

com o último sujeito. A emenda denuncia, afinal, a dificuldade de interpretar a forma $\pi \rho \circ \chi \varepsilon \imath \rho i \zeta \varepsilon \tau \alpha \imath$, que, como lição «mais difícil» (lectio difficilior), é normalmente adoptada pela maior parte dos modernos editores.

388 Propriamente, "acto de frisar, entrançar, encaracolar»; como, porém, o texto se refere também a outras operaçóes, pareceu (de certo modo!) razoável traduzir pelo termo de sentido geral "tratamento».

389 "dos maridos»: o texto diz, de modo menos vulgar, "daqueles com quem estão casadas».

${ }^{390} \mathrm{Ou}$ seja, «quase todos os perfumes da Arábia», região famosa pela produção dos mais variados e refinados perfumes.

391 "póem» (= calçam... vestem); o verbo, aliás, não está expresso; lit. ${ }^{\text {te }}$ : «... uns sapatinhos... e um vestido muito fino, para dar a impressáo de estarem nuas»; v. nota seguinte.

${ }^{392}$ Alguns mss. recentiores e certos editores modernos lêem e interpretam "para que não pareça que estão nuas»; a outra interpretação (que respeita a liçáo dos mss.) diz o contrário, o que parece mais provocante... que era isso mesmo que elas pretendiam.

393 Prece tratar-se de pérolas.

${ }^{394} \mathrm{O}$ talento náo era uma moeda propriamente dita, mas uma «moeda de conto" (cf. contos de réis) $=60$ minas; uma mina $=100$ dracmas; uma dracma $=$ 6 óbolos. Portanto, um talento $=6000$ dracmas. O termo talento podia referir-se, de maneira indeterminada, àquilo que designamos por «um balúrdio». 
mísero ouro desce até ao fundo das pernas, cobrindo a mais infima parte do calcanhar que esteja nua: bom seria que as suas pernas, na zona dos tornozelos, estivessem presas com grilhöes de ferro. ${ }^{\beta 95}$ Enfim, depois de todo o seu corpo ter ganho, com a graciosidade enganadora de uma beleza postiça, um aspecto fascinante, avermelham as despudoradas maçãs do rosto com tintura de algas, a fim de que o brilho purpúreo dê uma cor viva à sua pele muito pálida e sebosa.

42. Mas que vida é a delas, depois de todos estes preparativos? Assim que saem de casa, vão visitar todas as divindades que atormentam os seus esposos, divindades essas de que os pobres maridos nem conhecem os nomes, como, por exemplo, as Coliades e as Genetilides ${ }^{396}$, ou a deusa frigia, ou a festa comemorativa do amor infeliz do pastor. Depois, vêm as cerimónias secretas de iniciação,

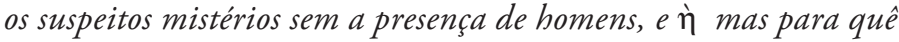

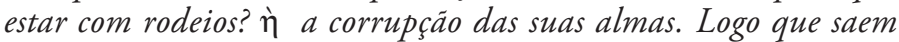
destas cerimónias, vem um longo banho em suas casas, e depois, por Zeus!, uma mesa requintada, e, enfim, muita provocação dissimulada ${ }^{397}$ com os homens. Quando, enfim, já estão cheias dos saborosos pratos à sua frente e a garganta já não é capaz de receber mais alimento, debicam com as pontas dos dedos e provam de cada um dos pitéus expostos; a seguir, falam das suas noitadas, das dormidas com parceiros de outro sexo ${ }^{398}$ e do leito exalando odor feminino, donde um homem sai a precisar imediatamente de um bom banho.

43. Estas são as características das mulheres de vida normal; se, porém, uma pessoa pretender analisar em pormenor a verdade sobre as mulheres mais desagradáveis, amaldiçoará Prometeu, fazendo ressoar as famosas palavras de Menandro ${ }^{399}$ :

${ }^{395}$ Creio que o discursante quer dizer, por ironia, que tanto ouro mereceria estar bem seguro, bem preso, para que náo o roubassem.

${ }^{396}$ As Colíades e as Genetílides eram divindades ligadas ao sexo, e cuja veneração, em cerimónias místicas de carácter orgiástico, estava reservada às mulheres; a deusa frígia é Cíbele, a Grande Mãe; o pastor é o belo Adónis, contra quem, no decurso de uma caçada, Afrodite lançou um javali que o feriu mortalmente.

397 "provocação dissimulada» pareceu-me o sentido mais adequado de akkismós ( $\alpha \kappa \kappa \imath \sigma \mu o ́ \varsigma)$, algo como "fazer-se rogada», "fazer-se cara», "fingir que não quer»... 398 «dormidas com parceiros de outro sexo" é uma das interpretaçóes; outros editores entendem "sonhos de mil cores».

${ }^{399}$ Fragm. 718 Koerte = p. 482 Loeb, Menander. Notar a forma métrica da tradução: nos primeiros oito versos, $7+3$ ou 4 sílabas; nos últimos dois, $10+3$ ou 4 sílabas. 
Não é então com justiça | que pregado

Prometeu nos representam | aos rochedos?

A seu lado está um facho, | único bem.

Todos os deuses odeiam, | bem o creio,

o ter moldado a mulher, | raça maldita.

Bons deuses! Casa-se um homem. | Casará?

Só maus desejos furtivos | doravante:

Goza o amante no leito | conjugal;

[Depois conspiraçôes ${ }^{400}$ ]

Venenos e ciúmes mais amargos $\mid$ que doenças,

para aquele com quem vive a vida inteira| uma mulher.

Quem ambiciona tais bens? A quem pode agradar esta vida desgraçada?

44. Agora convém confrontar com os vicios femininos o comportamento masculino dos rapazes. Ao levantar-se pela manhá do leito sem companhia ${ }^{401}$, lava-se e sacode ${ }^{402}$ com água simples o sono que ainda resta nos seus olhos, veste ${ }^{403}$ a pequena túnica e prende o manto aos ombros com fíbulas, após o que

da casa paterna sai,

de olhos pregados no chão... ${ }^{404}$

e sem olhar de frente para as pessoas que encontra. Os seus acompanhantes e pedagogos ${ }^{405}$ seguem-no em decente cortejo, tendo em suas máos os veneráveis instrumentos da virtude, não um pente com

${ }^{400}$ Esta frase, que parece ser um comentário de leitor ou copista, acabou por passar para o texto dos mss.; deve-se ao filólogo Bentley a sua eliminação.

401 "ao levantar-se do leito sem companhia», por hipálage, = "ao levantar-se, sem companhia, do leito", ou "ao levantar-se do leito, onde dormiu sem companhia».

402 «eleva-se e sacode»: o texto exprime estas duas ideias com um

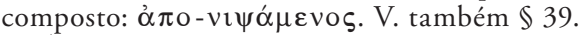

403 "veste... prende...»: o texto é elíptico, pois diz apenas "prende conjuntamente»; a ideia é, naturalmente, que veste a túnica, à qual prende com alfinetes, à altura dos ombros, o manto.

${ }^{404} \mathrm{O}$ aspecto métrico denuncia uma citação literária, de um fragmento de comédia não identificada. Em todo o caso, faz lembrar um passo das Nuvens de Aristófanes, onde se descreve o comportamento de um jovem dos tempos de antanho...

${ }^{405}$ Os acompanhantes eram simples criados "de serviço geral"; o pedagogo ( $\pi \alpha \imath \delta-\alpha \gamma \omega \gamma o ́ \varsigma)$, como a palavra indica, "conduzia o menino" à escola, mas já em Platão pode ter o sentido de "orientador (educador) de menino(s)». 
entalhes dentados, destinados a acariciar os cabelos, nem espelhos que reflectem imagens não pintadas ${ }^{406}$, mas antes seguem atrás dele tabuinhas multiarticuladas ou volumes ${ }^{407}$ que conservam as virtudes das obras antigas, ou então, se se trata de ir para a aula de música, uma lira melodiosa.

45. Tendo-se exercitado abundantemente em todos os preceitos filosóficos destinados à alma, e depois que o seu intelecto se saciou dos bens da cultura geral, treina o corpo com exercicios dignos de pessoa livre: interessa-se pelos cavalos tessálicos; e em breve, tendo domado, qual potro, a sua juventude, pratica, em tempo de paz, as artes da guerra, lançando dardos e disparando setas com máo certeira; em seguida, vêm as palestras ${ }^{408}$ untuosas, onde, ao calor meridiano do sol ${ }^{409}$, o seu corpo, cada vez mais forte, se cobre de poeira; depois, os suores escorrentes dos esforços das lutas, após os quais vem um curto banho e uma mesa frugal, adequada à disciplina que se segue um pouco depois. De facto, ai estão novos mestres, com seus preceitos alusivos e explicativos dos feitos dos antigos: que herói se revelou mui viril, ou quem se mostrou mais sensato, ou quais amaram mais a justiça e a temperança. Tendo "regado" $110 \mathrm{com}$ tais virtudes o seu espírito ainda tenro, quando a noite póe fim á sua actividade, e depois de pagar o devido tributo às necessidades do ventre, vai enfim dormir um sono muito agradável, descansando com todo o merecimento das fadigas de um dia inteiro.

46. Quem não se tornaria amante de um tal efebo? ${ }^{211}$ Quem seria cego a esse ponto. ${ }^{2112}$ Quem teria um tão fraco poder de raciocínio? Como não amaria esse outro Hermes nas palestras, esse outro Apolo como tocador de lira, esse outro Castor como cavaleiro, esse jovem

O Pseudo-Luciano refere-se à situação normal no Império Romano, em que o pedagogo era geralmente um escravo...

${ }^{406} \mathrm{O}$ texto é gramaticalmente confuso, mas a ideia parece clara, nomeadamente a alusão a imagens não pintadas: o espelho dispensa o uso da pintura para representar o rosto,,,

407 Volumes, ou seja, rolos de pergaminho ou papiro.

408 "palestra» significa "luta», "escola de luta».

${ }^{409}$ Hipálage, por "ao calor do sol do meio-dia".

410 «regado»: linguagem figurada, que tive por bem manter.

411 «efebo» é o termo grego que designa um jovem entre 16 e 18 anos; a palavra mancebo seria igualmente adequada.

412 A tradução à letra é complicada (até do ponto de vista do grego...): "Quem teria raios de olhos táo cegos?»; o mesmo se diga da frase seguinte. 
que, com corpo mortal, persegue as virtudes divinas? Pela minha parte, ó deuses celestes, oxalá a minha vida fosse continuamente esta: estar sentado em frente de um tal amigo e escutar de perto a sua doce voz, sair com ele quando ele saisse, e partilhar todas as actividades com ele. Um tal amante somente faria votos por que o seu querido chegasse sem sofrimento até à velhice, depois de uma vida irrepreensivel e sem vicissitudes. Caso, porém - pois tal é a lei da natureza humana -, alguma doença o atingisse, eu adoeceria juntamente com ele; se ele partisse por um mar tempestuoso, eu navegaria juntamente com ele; se a violência de um tirano lhe impusesse grilhôes, eu cingir-me-ia com os mesmos ferros; todo aquele que o odiasse seria meu inimigo, e eu amaria todos aqueles que tivessem bons sentimentos em relação a ele; se eu visse bandidos ou inimigos a atacá-lo, eu defendê-lo-ia ${ }^{413}$, mesmo para lá das minhas forças; e se ele morresse, eu não suportaria viver, e daria estas minhas últimas instruçôes àqueles que eu amasse, logo a seguir a ele: que elevassem um túmulo comum a ambos, que misturassem os ossos uns com os outros e que não separassem uma da outra a nossa muda cinza.

47. Estes meus amores não seriam os primeiros a determinar tais instruçôes em relação a pessoas dignas disso, pois a virtude dos heróis, próxima dos deuses, já assim havia estabelecido as leis, segundo as quais o fulgor da amizade se exala até ao momento da morte. A Fócida ligou, já desde os anos de infância, Orestes a Pílades, os quais, tendo tomado o deus [do amor] como mediador das suas paixóes mútuas, navegaram juntos, como que no mesmo barco: ambos mataram Clitemnestra, como se ambos fossem filhos de Agamémnon ${ }^{414}$; por ambos foi assassinado Egisto; foi Pilades quem mais sofreu, quando as Fúrias perseguiam Orestes, e foi ele quem o defendeu em tribunal; não limitaram a sua paixão amorosa às fronteiras da Hélade, mas navegaram até aos remotos confins da Citia, um doente, e o outro tratando dele; quando desembarcaram no pais dos Tauros, logo a Erinia vingadora do matricidio os acolheu, e enquanto os bárbaros se concentravam à sua volta, um deles jazia por terra, por efeito da sua loucura ordinária, enquanto Pílades

a espuma lhe limpava, | e de seu corpo tratava, e o cobria com um manto | de resistente tecido ${ }^{415}$,

${ }^{413} \mathrm{O}$ texto diz textualmente "eu armar-me-ia»...

414 Só Orestes era filho de Agamémnon; Pílades era seu primo.

${ }^{415}$ Eurípides, Ifigénia entre os Tauros, 311-312. 
revelando um sentimento, não só de amante, mas também de pai. Equando foi decidido que, enquanto um deles ficaria para ser morto, o outro iria a Micenas levar a carta, ambos queriam ficar em vez do outro, cada um deles considerando que viveria, se o outro conservasse a vida. Orestes recusa a carta, por entender que Pilades era mais digno de a receber, assim se tornando de amado em amador:

a morte do meu amigo | grande fardo é para mim,

qual capitão de navio | transportador de más novas ${ }^{416}$.

E pouco depois, diz:

sou eu quem o manda a Argos, | que se faça o seu desejo, e me mate quem quiser... ${ }^{417}$

Sim, é deste modo que tudo se passa. De facto, quando um amor verdadeiro, alimentado desde a infância, se desenvolve até à idade capaz de raciocinar, aquele que desde longa data foi por nós amado paga-nos com amor reciproco, e é difícil de distinguir qual é o amante de qual, como num espelho, em que se reflecte por igual a imagem do sentimento do amador e do ser amado ${ }^{418}$. Então porque é que censuras, como se isso fosse uma volúpia estranha à nossa natureza, uma prática fixada por leis divinas e que chegou até nós de geração em geração? Cuidamos dessa prática com muito agrado e de coração puro. Sim, é verdadeiramente venturoso, segundo a sentença dos sábios,

quem filhos jovens possui, | e solipedes cavalos ${ }^{419}$;

esse tal chega à velhice | e tranquilo envelhece;

todos os moços o amam.|... ${ }^{420}$

416 Id., ib., 598-599.

${ }^{417}$ Id., ib., 603-605. Neste passo e no anterior, adaptam-se as pessoas gramaticais.

${ }^{418} \mathrm{O}$ texto é, do ponto de vista gramatical, um autêntico quebra-cabeças, que nos faz pensar num falante de outra língua que tenta verter o seu pensamento para a língua grega...

419 Sólon, 23.

${ }^{420}$ Calímaco, Aetia, Fr. 41 Pfeiffer. 
Realmente, os ensinamentos de Sócrates e esse seu tribunal de virtude foram enaltecidos pelas tripodes délficas. Sim, o deus Pitio ${ }^{421}$ pronunciou um oráculo de verdade:

De todos os seres humanos,| Sócrates é o mais sábio.

De facto, não foi este que, entre outros ensinamentos com os quais beneficiou a vida humana, também reconheceu a pederastia como um bem precioso. ${ }^{2422}$

49. Devemos, pois, amar os jovens da maneira como Sócrates amava Alcibiades, com o qual dormia sob o mesmo manto, como se fosse um pai. Pela minha parte, e a concluir o meu discurso, acrescentaria com todo o gosto estes versos de Calímaco, como conselho para toda a gente:

Ó vós, que aos adolescentes $\mid$ ávidos olhos lançais, que a vossa pedofilia ${ }^{423} \mid$ à lei de Érquio ${ }^{424}$ se conforme; se assim os jovens amardes, | tereis pátria varonil.

Conscientes deste facto, vós, jovens adultos ${ }^{425}$, procurai sensatamente a companhia de meninos virtuosos, não prefirais as falsas paixôes do amor, ao trocardes por um efémero prazer uma longa amizade no seu mais alto grau, mas antes, prestando culto ao Eros celeste $^{426}$, conservai, desde a infância até à velhice, uma paixão constante. De facto, para aqueles que amam desta maneira, por um lado, o seu tempo de vida é extremamente delicioso, sem que neles resida qualquer remorso desagradável, e, por outro lado, depois da sua morte, espalha-se por entre as gentes a sua gloriosa fama.

${ }^{421}$ Apolo.

${ }^{422}$ Sigo a pontuação da ed. Loeb, que entende a frase de modo interrogativo.

${ }^{423} \mathrm{O}$ autor utiliza mesmo o termo (verbo) paidophileîn «amar meninos», que, por comodidade de traduçáo, traduzimos pelo substantivo correspondente.

${ }^{424}$ Pode tratar-se do andrónimo Érquio, que teria proposto uma lei relativa às relaçóes de um adulto com adolescentes, em que a amizade prevaleceria sobre o sexo, sem, no entanto, o excluir (?); também há quem sustente que a palavra significa "pessoa do demo de Erquia, na Ática", donde, "Xenofonte». De qualquer maneira, trata-se de uma lei (de um legislador de nome Érquio) ou de um conselho (do escritor e moralista Xenofonte), que advogava a legitimidade do amor entre adulto e adolescente.

${ }^{425}$ Creio que a palavra neanías significa, aqui, de acordo com o contexto, «jovens adultos», e não apenas «jovens».

${ }^{426}$ V. nota ao $\$ 32$, sobre os dois Eros ou Amores; v. $\$ 37$ 
Mais: a acreditar nos filósofos ${ }^{427}$, o éter, depois da vida terrena, acolhe os que optaram por esta via, $e$, ao morrerem para uma vida melhor, recebem a perpétua recompensa da sua virtude."

50. Tendo Calicrátidas pronunciado este discurso com muita veemência e ênfase, Cáricles preparava-se para replicar, mas eu retive-o, pois estava na hora de regressarmos ao navio. Como, porém, me rogassem que manifestasse a minha opiniáo, eu, depois de pesar por breves instantes os respectivos discursos ${ }^{428}$, disse: «Meus amigos: não me parece que os argumentos dos vossos discursos ${ }^{429}$ tenham sido organizados de improviso e sem preparação, mas, pelo contrário, há neles sinais bem visiveis de uma reflexão continuada e, por Zeus!, muito sólida. Não há, nos vossos discursos, praticamente nenhum pormenor que vós tenhais deixado para outra pessoa dizer; além disso, é grande a vossa experiência na matéria, mas ainda maior é a perfeição dos vossos discursos, de modo que eu desejaria, se tal fosse possivel, tornar-me no célebre Terámenes, o "Coturno" 330 , a fim de que vós ambos desfilásseis como vencedores ex aequo. Como, porém, me parece que vós não admitirieis adiamento, e como eu próprio decidi que, durante a viagem, não haveria mais perturbaçāo sobre o mesmo assunto, vou dar o parecer que, neste momento, tenho por mais justo.

51. Antes de mais, o casamento é uma coisa muito útil e venturosa para a vida dos homens, desde que dê certo; no que respeita, porém, às relaçôes amorosas com rapazes - isto é, aquelas que patrocinam castos e justos sentimentos de amizade -, considero que são exclusivamente do âmbito da filosofia. Nesta ordem de ideias, todos os homens em geral devem casar, mas reserve-se a pederastia exclusivamente para os sábios ${ }^{431}$, porquanto, entre as mulheres, a virtude é muitíssimo pouco perfeita. E tu, Cáricles, não fiques irritado pelo facto de Corinto ser vencida por Atenas."

427 O texto diz "nos filhos dos filósofos», expressão que nos lembra "o Filho do homem» = "Cristo»; aqui, seria o equivalente a "filósofos».

${ }^{428}$ Em vez de «discursos», poderíamos traduzir por «argumentos».

${ }^{429}$ Lit. $^{\text {te }}$ "as coisas (i. é, a matéria) dos vossos discursos".

430 Terâmenes, político do tempo da Guerra do Peloponeso, foi apelidado de "Coturno", pelo facto de se moldar a todas as circunstâncias, conforme a sua conveniência, tal como o coturno de tragédia, que servia a qualquer pé.

${ }^{431}$ Um manuscrito tem "para os filósofos», o que parece uma emenda, que o copista terá considerado óbvia, mas que, por isso mesmo, pode ser abusiva. 
52. Após ter dado o meu parecer à pressa e em breves palavras, levantei-me, por um sentimento de pudor, ao ver Cáricles cabisbaixo, quase como se tivesse sido condenado à morte. $\mathrm{O}$ ateniense, pelo contrário, de cara alegre e todo radioso, pulava e andava à nossa frente cheio de arrogância: dir-se-ia que acabara de desbaratar os Persas na batalha naval de Salamina. Mas uma coisa ganhei eu com o meu julgamento, que foi o facto de Calicrátidas nos ter oferecido um magnífico banquete para celebrar a vitória, pois ele era, de um modo geral, uma pessoa de espírito magnânimo. Mas também consolei calmamente Cáricles, exprimindo-lhe reiteradamente a minha grande admiração pelo talento revelado no seu discurso, tanto mais que tinha defendido com grande veemência a causa mais difícil.

53. Tal foi a nossa estada em Cnido, e foi mais ou menos assim que, no santuário da deusa, foram julgados estes discursos, cheios, ao mesmo tempo, de alegre seriedade e de culta brincadeira. Mas agora tu, Teomnesto, que me fizeste evocar uma memória já antiga, que sentença pronunciarias, se fosses tu então o juiz?

TEOMnesto - Pelos deuses! Cuidas que eu sou algum Melítides ${ }^{432}$ ou algum Corebo, para emitir um voto contrário à sentença por ti tão justamente pronunciada? Estava tão embalado pelo extremo prazer dos discursos, que me imaginava estar mesmo em Cnido, e pouco faltou para cuidar que esta exígua casinha era aquele famoso ${ }^{433}$ templo. Em todo o caso (uma vez que, em dia de festa, nada é inconveniente de se dizer, mas antes toda a jocosidade, ainda que brejeira, é tomada à conta das comemoraçóes), admirei bastante, pela sua gravidade, as veementes palavras em favor da paixão por rapazes ${ }^{434}$. Todavia, julgo que não é mesmo nada agradável, para quem passa dias inteiros na companhia de um moço adolescente, sofrer a pena de

${ }^{432}$ Melítides e Corebo eram figuras tradicionais de idiotas; ao primeiro alude Aristófanes nas Rãs, 991; o segundo é citado por Luciano em $O$ Mentiroso, 3.

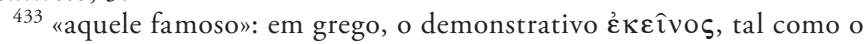
lat. ille, podem ter sentido magnificativo: "aquele famoso»...

${ }^{434} \mathrm{O}$ texto diz "pederastia", no sentido de "amor dedicado aos moços»; naturalmente, em português, quer pederastia, quer pedofilia, têm um sentido sexual nem sempre presente em grego, como se vê a seguir. 
Tântalo ${ }^{435}$, com a formosura do rapaz quase a inundar-lhe ${ }^{436}$ os olhos, e, podendo agarrá-la, sofrer de sede. Realmente, não basta contemplar o ser amado, nem ouvi-lo falar, sentado diante de nós, pois o amor, ao fixar para si como que uma escala de prazer, tem como primeiro grau a vista, e, depois de ver e contemplar, aspira a ir mais longe e tocar. Então, basta tocar apenas com a ponta dos dedos, o mecanismo do prazer estende-se a todo o corpo. Depois, atingida facilmente esta fase, segue-se a terceira experiência, a do beijo, não muito impetuoso logo de início, mas roçando levemente com os lábios nos outros lábios, de modo que, antes de lhes tocar completamente, afastam-se, sem deixarem qualquer indício de suspeição. A seguir, adaptando-se ao que lhe vai sendo concedido, derrete-se em abraços cada vez mais persistentes, chegando a abrir-lhe docemente a boca e não deixando qualquer das mãos inactiva. De facto, os abraços não disfarçados, com a pessoa vestida, suscitam prazer, ou então a mão direita, furtiva e docemente afundada no seio do jovem, comprime-lhe levemente os mamilos, mais inchados do que é natural, e a seguir, com os dedos, em movimentos circulares e regulares, afaga-lhe o baixo-ventre já túmido, e depois de tudo isto, a primeira penugem que é a flor da juventude... Mas...

\section{Para quê enumerar | o que não deve ser dito? $?^{437}$}

Depois de conseguir esta liberdade, a paixão atinge um certo ponto bem mais quente, até que, enfim, principiando pelas coxas, como diz o poeta cómico ${ }^{438}$, «bate mesmo no ponto».

54. Seja, pois, esta a minha ideia de "pederastia». Que aqueles que lançam palavras ao vento e todos quantos erguem as sobrancelhas da filosofia bem acima da testa endrominem os ignorantes com subtilezas de palavras imponentes. O próprio

435 Tântalo, um dos grandes supliciados da mitologia, foi condenado a suportar eternamente a sede, no Inferno; o suplício era refinado pelo facto de estar junto da água, a qual lhe escorria das máos, logo que a levava à boca. Percebe-se a comparação.

436 «inundar» é o termo usado no texto grego, a fim de melhor corresponder à comparação com o suplício de Tântalo, em que a água do rio lhe inundava o corpo e quase lhe chegava à boca.

437 Eurípides, Orestes, 14.

${ }^{438}$ Náo foi possível identificar o poeta cómico que disse tal frase. 
Sócrates era especialista no amor como aqueles que o são, e no entanto, Alcibíades, tendo-se deitado com ele sob o mesmo manto, não se levantou de lá indemne ${ }^{439}$. E não te espantes, pois nem mesmo Pátroclo era amado por Aquiles só pelo prazer de se sentar diante deste,

aguardando que o Eácida $\mid$ pusesse fim ao seu canto ${ }^{440}$,

mas existia também um deleite mediador da sua amizade. De facto, quando Aquiles lamenta a morte de Pátroclo, a sua dor incontrolável irrompe em expressão de verdade,

prestei culto às relaçóes |que entre nossas coxas houve, choroso... ${ }^{441}$

Mais: julgo que os denominados, entre os Gregos, comastas, outra coisa não são, senão claros amantes. Alguém dirá, talvez, que é vergonhoso falar deste assunto, mas... por Afrodite de Cnido!, é a verdade.

LICINO - Não vou permitir, meu amigo Teomnesto, que tu despejes um outro exórdio de um terceiro discurso, exórdio que, obviamente, e só ele, eu poderia escutar durante toda a festa, enquanto tudo o mais estaria fora do alcance dos meus ouvidos. Deixemos, pois, de nos demorarmos mais tempo, e encaminhemo-nos para a ágora, pois parece que já estão a puxar fogo à pira em honra do deus ${ }^{442}$. Náo é nada desagradável o espectáculo que recorda aos espectadores o seu sofrimento no monte Eta.

439 Note uma versão oposta à que é expressa por Calicrátidas no $\$ 49$.

440 Iliada, IX, 191.

${ }^{441}$ Ésquilo, fragmento 136, provavelmente dos Mirmídones. Trata-se, evidentemente, de parte de uma tirada de Aquiles, mas a falta do contexto dificulta a tradução.

442 Trata-se de Héracles e da sua imolação e purificação pelo fogo no monte Eta. 
(Página deixada propositadamente em branco) 
A DANÇA 
(Página deixada propositadamente em branco) 
Como é que a dança não seria uma coisa altamente harmoniosa, ela que aguça a alma, exercita o corpo, deleita os espectadores e lhes ensina muitas coisas dos tempos antigos, ao som das flautas e dos cimbalos, e com a cadência e o encanto de melodias dirigidas aos olhos e aos ouvidos?! 
(Página deixada propositadamente em branco) 


\section{A DANÇA}

\section{INTRODUÇẤO}

Depois de muito viajar, mas antes de se fixar em Atenas, Luciano passa alguns anos (162-165 d.C.) na sua Síria natal, na cidade de Antioquia, onde iniciara a sua carreira de advogado. Conjugando diversos indícios, como o facto de o imperador Vero, grande apreciador da dança, ter estado por esse tempo em Antioquia, podemos conjecturar que $A$ Dança foi escrita nessa cidade entre os anos de 162 e165 d.C.

A obra apresenta-se sob a forma inicial (\$\$ 1-6) de diálogo entre Licino (Luciano) e o seu amigo e filósofo cínico, Cráton, mas acaba por ser uma longa exposição ( $\$ \$$ 7-85), um monólogo em defesa da dança, após o que Cráton se limita a fechar o pseudo-diálogo, dando-se por vencido e convencido.

O leitor moderno e, além disso, desprevenido, pode muito facilmente associar a dança antiga à dança moderna, com o que incorre numa tremenda confusão. De facto, a dança moderna é (sem com isto lhe retirarmos o seu valor artístico) um simples acompanhamento da música, em que os pés têm o papel principal, ainda que possam ser executados outros movimentos. Mas esta dança, em si mesma, não exprime qualquer tema, apenas varia de acordo com os diversos tipos de música (valsa, tango...).

$\mathrm{Na}$ Antiguidade, porém, a dança era uma arte muito mais complexa e muito mais completa, mais parecida com o moderno ballet, ou até uma espécie de mistura de ballet e ópera, mas ainda mais do que isso: era a arte de representar por movimentos e gestos, por mímica pura, todas as paixões da alma, em consonância com a acçáo de outros artistas, que, à volta da cena, desempenhavam diversos papéis: um cantava um texto, apoiado por um coro, outro acompanhava-o à flauta ou à siringe (flauta de Pã), outro marcava o ritmo com uma sandália ferrada. $\mathrm{O}$ dançarino, por sua vez, provido de uma máscara bastante mais leve que a da tragédia e com vestes apropriadas à personagem representada, era a figura mais destacada e mais visível do conjunto, figura muda, que tentava transmitir aos espectadores uma das variadíssimas histórias de que a mitologia grega é farta. É oportuno citar aqui as palavras do próprio Luciano $(\$ 62)$ : 
"Ora, uma vez que a sua arte é imitativa e lhe compete interpretar por gestos aquilo que outros cantam ${ }^{443}$,é imprescindivel que o dançarino, à semelhança dos oradores, exercite a clareza, de forma que cada episódio por ele executado seja entendido sem necessidade de intérprete, mas antes, como disse o oráculo pitico, quem assista a uma dança deve compreender um mudo e ouvir o que o dançarino diz sem falar."

No parágrafo seguinte ( $\$ 63)$, Luciano conta uma história muito esclarecedora: um dançarino do tempo de Nero demonstra ao filósofo cínico Demétrio o poder da dança como autêntica linguagem. De facto, tendo mandado calar os cantores, o coro e os músicos, executou, exclusivamente por mímica, alguns episódios da mitologia, após o que Demétrio, encantado com a actuação e com a clareza da interpretação, fez o maior elogio que se pode fazer a um dançarino, elevando a voz e gritando a plenos pulmóes: "Ó homem! Eu oiço, e não apenas vejo, o que tu fazes, pois tenho a impressáo de que tu falas com as próprias mãos.» Logo a seguir, conta-nos a história de um bárbaro que pretendia levar esse mesmo dançarino para a sua terra, a fim de, por meio da dança, lhe servir de intérprete junto dos diversos povos da vizinhança, que falavam variadíssimas línguas.

É claro que náo podemos evitar a associação com o Zorba de Nikos Kazantzákis e, mais ainda, com o célebre filme baseado nesse romance, em que o protagonista, nos momentos de tensão máxima, só sabia exprimir-se por dança.

Deve dizer-se que, no tempo de Luciano (e não só), certas actividades eram claramente depreciadas pelos intelectuais, como, por exemplo, o romance e, no caso vertente, os espectáculos de dança, que faziam concorrência à tragédia, mas que, nitidamente, eram bastante mais acessíveis ao grande público. Depois, a moda muda, e toda a gente passa a gostar de... fado, futebol... quer dizer... é de «bom-tom»...

Ora, o intelectual Luciano tem o mérito de, muito antes dos outros, e contra a corrente, ter reparado no valor artístico, cultural e formativo da dança.

Este seu amigo e filósofo, Cráton, devia estar influenciado por outros intelectuais que depreciavam o espectáculo popular que era a dança. Entre esses intelectuais, parece contar-se

${ }^{443}$ Esta informação é muito importante: o dançarino só representa o que outros cantam. 
especialmente o famoso sofista Élio Aristides, contemporâneo de Luciano, mas que este não cita claramente.

Esta obra de Luciano reveste-se da maior importância pelas informaçóes que presta ao estudioso moderno. Por outro lado, é bastante elucidativo para nós, como era, em primeiro lugar, para os leitores antigos, nomeadamente para os dançarinos, o longo catálogo de tópicos mitológicos, cujo conhecimento em extensão e em profundidade devia constituir o lastro cultural do artista. Ainda que apresentado com a identificação mínima, esse conjunto de tópicos remete para uma mole fabulosa de histórias e episódios, que abarcam todo o mundo helénico e, supostamente, vão desde os tempos primitivos da cosmogonia do Universo até «factos» mais recentes, como a história de Cleópatra, que, pelos vistos, chegou a ser motivo de representação dramática.

De toda a maneira, Luciano náo pretende elaborar um autêntico tratado sobre a dança, caso em que teria de se referir, por um lado, às suas origens e desenvolvimento pormenorizado através dos tempos, e, por outro lado, aos variadíssimos tipos ou géneros de dança: guerreiras, religiosas, dramáticas, privadas e populares, cada um desses géneros dividido em diversos tipos, com a respectiva identificaçáo, o que, obviamente, extravasaria do objectivo principal da obra, que consiste em mostrar ao seu amigo Cráton o valor da dança, toda a dança (sem esmiuçar aspectos particulares), como actividade cultural, deleitosa e formativa, e não como coisa grosseira e ordinária, "desprezível e efeminada» ( $\$ 1)$ que o seu amigo julgava ser.

No $\$ 72$, Luciano resume em poucas palavras os benefícios da dança: "Como é que a dança náo seria uma coisa altamente harmoniosa, ela que aguça a alma, exercita o corpo, deleita os espectadores $e$ lhes ensina muitas coisas dos tempos antigos, ao som das flautas e dos címbalos, e com a cadência e o encanto de melodias dirigidas aos olhos e aos ouvidos?!"

Não admira, pois, que, com um tal poder de exposição e de argumentação, Licino (ou seja, Luciano) consiga convencer converter - o seu renitente amigo Cráton, o qual, mesmo a concluir, declara: "Agora sim, Licino, já me deixo convencer por ti e fico com os ouvidos e os olhos bem abertos. Mais: quando fores ao teatro, lembra-te, querido amigo, de reservar também um lugar para mim, ao teu lado, para que não sejas só tu a regressar de lá mais instruído.»

Como se disse, Luciano não pretende, nesta obra, escrever nem um verdadeiro tratado sobre a dança, nem um tratado 
de mitologia. Pela parte que toca ao tradutor e anotador, devo dizer que seria muito "indigesto" fazer acompanhar de um resumo mitológico, em notas de rodapé, cada um dos muitos episódios, ou tópicos, apenas mencionados por Luciano a título de memorando (\$\$ 37-61), cuja simples leitura já... cansa. O próprio Luciano adverte o seu amigo (fim do $\$$ 61): "Para dizer em poucas palavras, [o dançarino] não deve ignorar nada do que foi escrito por Homero, por Hesiodo e pelos melhores poetas, especialmente os trágicos." E continua: "De entre tantas, melhor, de entre a multidão infinita de histórias, seleccionei apenas estas, as mais importantes, deixando as outras para os poetas cantarem, para os dançarinos representarem e para tu descobrires outras mais, por associação com as que ficam acima mencionadas, histórias essas, que obrigatoriamente o dançarino deve ter à mão, preparadas e armazenadas para utilizar cada uma em ocasiāo oportuna."

Se o leitor pretender desenvolver algum destes pontos (história da dança e seus diversos tipos e caracterização, bem como a história completa de cada episódio mitológico), deve recorrer a obras específicas, das quais se indicam as seguintes:

LAVEDAN, P., Dictionnaire illustré de la mythologie et des antiquités grecques et romaines. Paris, Hachette. Além das informaçóes mitológicas, v. o artigo "DANSE».

VARII, The Oxford Classical Dictionary. Oxford, Clarendon Press.

HARVEY, P., The Oxford Companion to Classical Literature. Oxford, Clarendon Press.

Grimal, P., Dicionário da Mitologia Grega e Romana. Trad. port. de Victor Jabouille, Cristina de Sousa Pimentel, Cristina Negrão Abranches, Arnaldo do Espírito Santo e Manuel José Barbosa, $4^{\mathrm{a}}$ ed., Difel, 2004.

PinheIro, Marília P. Futre, Mitos e Lendas - Grécia Antiga. Vol. I. [Lisboa] «Livros e Livros» 2007.

Duas obras de divulgação, cultura e... entretenimento, para um público jovem ou não especializado:

Guillemin, A.-M., Récits mythologiques. Paris, Hatier, 2a ed., 1936. A mitologia "romanceada», dirigida "ao público cultivado e aos estudantes do ensino secundário», é obra 
muito agradável de se ler. [Nota: Há uma tradução, de C. M., entregue num editor.]

Buongiorno, T., Olimpo - Diário duma Deusa Adolescente. Trad. port. de Sílvia Matos e Lemos, ed. Terramar, Lisboa, 1995 (reimpr. 2000).

LOURENÇO, Frederico, A Odisseia de Homero adaptada para jovens. Lisbos, Livros Cotovia, 2005. 
(Página deixada propositadamente em branco) 


\section{A DANÇA}

1. LICINO - Uma vez que tu, Cráton, tens vindo a fazer uma acusação de certo modo violenta e, creio eu, de há muito elaborada, contra as danças e a própria arte de dançar, bem como contra nós próprios ${ }^{44}$, os que nos comprazemos com tal espectáculo, pelo facto de darmos grande importância a uma actividade alegadamente desprezível e efeminada, escuta cá como estás redondamente fora da razão, ao acusares inconsideradamente o maior dos bens desta vida. Em todo o caso, perdoo-te, atendendo a que, por teres vivido desde sempre num estilo de vida austero e considerares que só é bom aquilo que é duro, é por simples ignorância desta matéria que tu a tens julgado digna de censura.

2. CRÁTON - Mas afinal, ó Licino, que tipo de homem és tu, criado em ambiente cultural e convivendo razoavelmente com a filosofia, para assim deixares de te ocupar de assuntos mais sérios e da convivência com os antigos, para ires escutar, sentado, o som da flauta e contemplar um homem efeminado, com vestes delicadas, pavoneando-se com cantigas obscenas e desempenhando o papel de mulherzinhas apaixonadas, de entre as mais lascivas da antiguidade, umas Fedras ${ }^{445}$, Parténopes e Ródopes, e tudo isso acompanhado com acordes musicais, árias e batimentos de pés, coisas verdadeiramente ridículas e absolutamente nada próprias de um homem livre e da tua condição?! Por isso é que eu, ao saber que tu gastavas o teu tempo com semelhante espectáculo, não só senti vergonha por ti, mas também fiquei muito triste pelo facto de tu, esquecido de Platão, Crisipo e Aristóteles, te comportares, ali sentado, como as pessoas que coçam as orelhas com uma pena ${ }^{446}$, tanto mais que existem muitas outras coisas sérias para ouvir e ver, se uma pessoa sentir necessidade disso, tais como flautistas ambulantes e músicos que acompanham à cítara árias decentes, e, sobretudo, a respeitável tragédia e a divertidíssima comédia, géneros que mereceram figurar em concursos.

${ }^{444}$ Aqui, nós próprios também pode ser o chamado «plural majestático».

445 Fedra: refere-se à paixão de Fedra, segunda esposa de Teseu, pelo seu enteado Hipólito; Parténope e Ródope são duas jovens, que haviam feito voto de virgindade, mas que acabam por não resistir á paixáo.

446 "coçar as orelhas com uma pena»: a expressão faz obviamente referência a qualquer entretenimento fútil. 
3. Portanto, meu bom amigo, necessitas de um longo discurso de defesa junto dos intelectuais, se não queres ficar completamente isolado e rechaçado da sociedade da gente séria. Mas o melhor ainda - julgo eu — é remediar a situaçấo com um desmentido absoluto e não admitir, desde já, que andes metido em semelhante aberração. E de agora em diante, cuida de não nos enganares, ao transformares-te, do homem que tu eras, numa qualquer Lídia ou numa Bacante, coisa que constituiria um motivo de censura não só contra ti, mas também contra mim, pelo facto de, como no caso de Ulisses, náo te ter afastado do "lótus" e não te ter reconduzido às ocupaçôes habituais, antes de, sem dares por isso, ficares apanhado pelas "Sereias" do teatro. Aquelas outras ${ }^{447}$, porém, atacavam somente os ouvidos, pelo que bastava a cera, para passar adiante, ao passo que tu pareces completamente escravizado também através dos olhos.

4. LICINO - Ui! Ó Cráton, como soltaste contra nós esse teu cấo ${ }^{448}$ de dentes afiados! No entanto, essa comparaçáo que invocaste, a imagem dos Lotófagos e das Sereias, parece-me bem diferente do que se passa comigo, porquanto aqueles que provaram o lótus ou escutaram as Sereias tiveram a morte como castigo do que comeram ou escutaram, ao passo que, no meu caso, além de isso produzir em mim um prazer enorme, tem resultado num fim feliz. De facto, não caio no esquecimento dos interesses de minha casa nem no descuido dos meus próprios interesses, mas antes, se me é permitido falar francamente, volto sempre do teatro muito mais sensato e mais clarividente das coisas da vida. E mais: é adequado citar aquele passo de Homero, segundo o qual aquele que assistiu a um tal espectáculo

... deleitado, || prossegue seu caminho, mas mais sábio. ${ }^{449}$

CRÁTON — Por Héracles, ó Licino! Como tu estás apanhado, a ponto de náo sentires vergonha disso, mas, pelo contrário,

447 "Aquelas outras», quer dizer, as Sereias do episódio de Ulisses, e não as «Sereias» do teatro, naturalmente em sentido figurado.

448 Esta referência ao cão justifica-se pelo facto de Cráton ser um filósofo cínico, gr. кvvıкós.

${ }^{449}$ Odisseia, XII, 188. Trata-se da fala das Sereias, que querem atrair Ulisses, mas este defende-se, ordenando aos companheiros que o amarrem ao mastro do navio. 
até te mostras vaidoso. Mas o mais terrível de tudo é que tu, ao ousares elogiar uma actividade tão vergonhosa e tão desprezível, não nos deixas entrever nem sequer um poucochinho de esperança de cura.

5. LICINO - Ora diz-me cá uma coisa, ó Cráton: é por teres assistido muitas vezes, em pessoa, a sessóes de dança e do mais que se passa no teatro, que tu condenas essa actividade, ou será que, sem teres experimentado tal espectáculo, assim mesmo o consideras, como tu dizes, vergonhoso e desprezível? Se já assististe, estás em pé de igualdade comigo; caso contrário, vê lá bem se a tua censura não parecerá absurda e temerária, ao incriminares uma actividade que desconheces.

CRÁTON - Era só o que me faltava, que eu, com esta longa barba e estes cabelos grisalhos, me sentasse no meio de mulherzinhas e de espectadores desatinados, e ainda por cima batendo palmas e gritando elogios inadequados a um qualquer devasso que se desfaz em lágrimas ${ }^{450}$ de uma maneira indecente.

LICINO - Essas tuas palavras são desculpáveis, Cráton. Todavia, se acaso me desses ouvidos e te dispusesses, a título de experiência, a dar só uma olhadela, estou certo de que náo te conterias, que não fosses apanhar, antes dos outros, um lugar bem situado, donde pudesses ver e ouvir tudo muito bem.

CRÁTON - Que eu não tenha nem mais uma hora de $v i^{4}{ }^{451}$, se alguma vez tolerasse uma coisa assim, enquanto eu tiver fartos pêlos nas pernas e o queixo não rapado. Como eu neste momento te deploro, ao ver-te completamente em delírio!

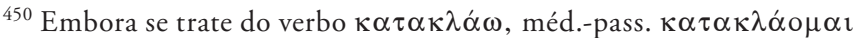
"quebrar-se todo", talvez "esfarrapar-se» (em sentido figurado), considero também a possibilidade de uma conotaçáo com o verbo $\kappa \alpha \tau \alpha \kappa \lambda \alpha \alpha^{\prime}$ (= $^{\circ}$ $\kappa \alpha \tau \alpha \kappa \lambda \alpha i \omega)$ "chorar muito», desfazer-se em lágrimas».

451 «Que eu não tenha nem mais uma hora de vida, se...» é a minha interpretação; a frase também pode equivaler a "Raios me partam, se...»; outra interpretação, de uma velha "traduction nouvelle" de Eugène Talbot, (Hachette) 1857, p. 480: "Que je ne voie pas la saison prochaine», mas, em passo igual dos Diálogos das Cortesãs (10, 3: "Quelidónio e Dróside»), traduz por "Aux corbeaux le bélître, qui...». A interpretação da ed. Loeb - "May I never reach ripeness of years, if...» - náo me parece correcta, pois a pessoa que fala, Cráton, estaria falando de si própria como pessoa ainda jovem, quando, um pouco antes, exclamara: «Era só o que me faltava, que eu, com

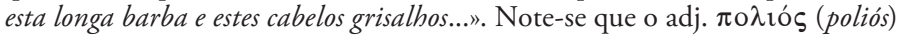
também pode significar «branco». De qualquer modo, Cráton refere-se a si mesmo como pessoa já razoavelmente entrada em anos, e não como um jovem. 
6. LICINO - Queres tu, companheiro, deixar-te dessas calúnias e escutar o que eu tenho a dizer sobre a dança e sobre a beleza que há na dança, como ela é não só agradável, mas também útil aos espectadores, quanta cultura nos fornece e quantas liçôes nos dá, como transmite harmonia às almas dos espectadores, como nos exercita através de belíssimos espectáculos e nos faz passar o tempo com as melhores árias e nos mostra uma beleza que é comum à alma e ao corpo? Sim, o facto de ela fazer tudo isso acompanhada de música e de ritmo não poderá constituir motivo de censura, mas antes de louvor.

CRÁTON - Antes de mais, não tenho muito tempo para escutar um sujeito louco fazendo o elogio da sua doença. Se tu, porém, te dispóes a lançar sobre mim algumas frivolidades, estou pronto a submeter-me a essa tarefa vinda dum amigo e a dar-lhe ouvidos, pois sou capaz de evitar ouvir disparates sem pôr cera nas orelhas. Portanto, vou já calar-me, e tu vai falando quanto quiseres, como se ninguém estivesse a ouvir.

7. LICINO - Muito bem, Cráton, era mesmo isso o que eu pretendia. Sim, em breve saberás se ainda achas que é um disparate o que eu vou dizer.

Em primeiro lugar, há uma coisa que tu, segundo parece, desconheces em absoluto: que a prática da dança não é uma coisa nova, que não teve início nem ontem nem anteontem, nem, digamos, no tempo dos nossos avós ou dos avós deles, pois os investigadores das origens que escreveram as informaçóes mais fidedignas a respeito da dança dir-te-iam que a dança surgiu logo no nascimento do universo, que ela apareceu ao mesmo tempo que esse primitivo ${ }^{452}$ Eros. De facto, a dança dos astros e o entrelaçamento dos astros errantes com os astros fixos ${ }^{453}$, a sua associação bem ritmada e a sua concertada harmonia constituem modelos da dança primitiva. Entáo, a pouco e pouco, foi-se desenvolvendo, sempre recebendo contribuiçôes no sentido do seu aperfeiçoamento, até que,

${ }^{452} \mathrm{Na}$ Teogonia de Hesíodo (v. 120), Eros vem imediatamente a seguir ao Caos e a Gaia (Terra). É, pois, um deus da primeira geração, que, rigorosamente, náo podemos assimilar ao delicado filho de Afrodite, menino travesso que se entretinha a mandar setas apaixonantes.

453 Os astros «errantes» $(\pi \lambda \alpha \nu \hat{\eta} \tau \alpha \imath)$ são os planetas; os fixos, «não errantes» ( $\alpha \pi \lambda \alpha v \varepsilon \hat{\imath} \varsigma)$ são as estrelas. Desde muito cedo, os antigos notaram que certos astros (a maioria) mantinham as sua posiçóes relativas, enquanto outros «erravam» pelo céu, ora numa posição, ora noutra, em relação aos astros fixos. 
nos dias de hoje, atingiu, ao que parece, o cume da perfeição e se tornou um bem multifacetado, altamente harmonioso e que engloba diversas musas.

8. Foi Reia quem, segundo se diz, encantada com esta arte, exortou à prática da dança os Coribantes ${ }^{454}$ na Frígia e os Curetes em Creta; e não foi pouco o que lucrou com esta arte, pois estes Curetes, dançando à sua volta, salvaram o seu filho Zeus, de tal modo que este poderia sem dúvida reconhecer que lhes deve um sacrifício de acção de graças, pois, graças à sua dança, escapou dos dentes paternos. A sua dança incluía armamento, batendo com as espadas nos escudos e marchando freneticamente e em passo de guerra.

Depois, os mais ilustres de entre os Cretenses passaram a exercitar-se nesta arte, tornando-se excelentes dançarinos, e não só os simples cidadãos, mas também os membros da realeza e aqueles que aspiravam a lugares de chefia. Homero até chamou "dançarino» a Meríones, no intuito, não de o desonrar, mas de o elogiar; este tornou-se tão famoso e conhecido em toda a parte pela sua arte de dançar, que não eram só os Gregos a reconhecer a sua arte, mas também os próprios Troianos, apesar de serem inimigos. Realmente, viam — julgo eu — a sua ligeireza e graça de movimentos em combate, qualidades que ele havia adquirido com a dança. Os versos de Homero dizem mais ou menos ${ }^{455}$ o seguinte:

Meriones, conquanto possas ser, || na arte de dançar, muito ligeiro, te deterá em breve minha lança. $\| \ldots{ }^{456}$

Todavia, não o deteve, porquanto, bem treinado como estava na arte de dançar, evitou sempre, e facilmente, creio eu, os ataques de lança desferidos contra si.

${ }^{454}$ Os coribantes eram companheiros de Reia-Cíbele. «Submetidos a abstinências que exaltavam a sua disposição para o êxtase, entregavam-se a danças rodopiantes, acompanhadas de gritos selvagens, ao mesmo tempo que retalhavam os braços com uma arma bem afiada e se chicoteavam com correias de ossinhos.» (A.-M. Guillemin, Récits mythologiques, p. 237)

455 «mais ou menos o seguinte»: na verdade, a citação é exacta, mas Luciano, aqui como noutros passos, cita de memória. Em todo o caso, a correcçáo métrica já apontava para a exactidáo da citação...

${ }^{456}$ Ilíada, XVI, 617-618. Note-se que, aqui e noutros passos, traduzi o hexâmetro dactílico em dois decassílabos heróicos, separados por uma cesura (||). Naturalmente, não há maneira de reproduzir fielmente o verso grego. 
9. Embora possa mencionar muitos outros, de entre os heróis, que se exercitaram nesta prática e que dela fizeram uma arte, creio suficiente fazer referência a Neoptólemo, filho de Aquiles, que muitíssimo se notabilizou na dança e lhe acrescentou este género belíssimo, denominado "pirríquio», do seu nome ${ }^{457}$. Estou convicto de que Aquiles, ao ouvir falar desta habilidade do seu filho, se orgulhava mais disso, do que da sua beleza e da sua força. De facto, foi a arte de dançar de Pirro que tomou Ílion, até então inexpugnável, e a arrasou por completo ${ }^{458}$.

10. Os Lacedemónios, que são considerados os mais valentes dos guerreiros gregos, tendo aprendido de Pólux e Castor a dança cariática (que é um género de dança executado em Cárias, na Lacónia), procedem em tudo de acordo com as Musas, a ponto de irem para a guerra ao som da flauta e em marcha ritmada e rigorosamente ordenada. É a flauta que dá aos Lacedemónios o primeiro sinal de combate. Eis o motivo por que eles têm vencido todos os inimigos, conduzidos ao som da música e com passo cadenciado.

Ainda nos dias de hoje, poderás ver os seus mancebos aprenderem a dançar, não menos do que a lutar com armas. De facto, logo que cessam de lutar com os punhos, e depois de esmurrarem e serem por sua vez esmurrados, a luta termina com uma dança: um flautista senta-se ao centro, tocando e marcando o ritmo com o pé, enquanto eles, seguindo-se uns aos outros em fila e marchando ritmicamente, executam figuras de toda a espécie, umas de natureza bélica, e logo a seguir outras de natureza coral, tão do agrado de Dioniso e de Afrodite.

11. Assim, o canto que eles entoam ao mesmo tempo que dançam constitui um convite a Afrodite e aos Amores, para que venham festejar e dançar com eles. O segundo desses cantos (pois são executados dois) contém uma instrução que diz como se deve dançar: "Em frente, rapazes - diz o canto —, alongai a perna e festejai melhor», ou seja, dançai melhor ${ }^{459}$.

${ }^{457}$ Pirro é um outro nome de Neoptólemo. «Pirríquio», «dança pírrica», era uma dança guerreira executada com todo o equipamento e armas.

${ }^{458}$ Neoptólemo, ou Pirro, filho de Aquiles. Após a morte de seu pai, o adivinho Heleno informou os Gregos de que Tróia só poderia ser tomada, se fossem buscar Neoptólemo; daí esta referência ao seu papel decisivo.

459 Este acrescento fora das aspas tanto pode ser uma explicação de Luciano, como um comentário de copista posterior... 
12. Do mesmo modo procedem os que executam a dança chamada «hormo» [colar]. O «hormo» é uma dança comum a efebos e a raparigas, que dançam em fila, um a um, dando realmente a ideia de um colar. À frente, vem um efebo, que dança à maneira de um rapazinho, e depois como deve fazer mais tarde, na guerra; vem a seguir uma moça, que mostra como uma jovem deve dançar pudicamente e como o "hormo» é uma mistura de pudor e virilidade. Há também as gimnopédias, que são um tipo de dança igualmente executado entre eles.

\section{Quanto à descrição feita por Homero no Escudo, a respeito} de Ariadna e do coro que Dédalo preparou para ela, passo-a em claro, pois deves tê-la lido, bem como os dois dançarinos aos quais o poeta, nesse passo, chama acrobatas, que dirigem o coro, e ainda o que o poeta diz na descrição do escudo ${ }^{460}$ :

... || rodopiavam jovens dançarinos,

como se isso fosse a coisa mais bela que Hefesto tivesse gravado no escudo. Também era natural que os Feaces se comprazessem com a dança, como povo refinado que eram e vivendo em plena felicidade. Foi por isso que Homero mostrou Ulisses a admirá-los muitíssimo e a contemplar o rápido movimento dos seus pés.

14. Na Tessália, a prática da dança gozava de um tal prestígio, que davam aos seus comandantes e ao seus generais o título de "chefes de dança» [proorkhestêres]. Demonstram esse facto as inscriçōes das estátuas que eles erigiram aos mais ilustres: "A cidade - diz uma inscrição - elegeu-o proorkhestêr»; e outra inscrição diz: "A Eilátion, o povo [dedicou] esta imagem, por ter bem dirigido a dança na batalha». ${ }^{461}$

15. Escusado será dizer que não é possível encontrar ritos de iniciação antigos, que não incluam a dança, já que, com toda a evidência, foram Orfeu e Museu, os melhores dançarinos desse

${ }^{460}$ Ilíada, XVIII, 468-617. Trata-se da célebre descrição do escudo de Aquiles, fabricado e ornamentado por Hefesto, a pedido de Tétis.

${ }^{461} \mathrm{O}$ editor da Loeb duvida da autenticidade destas inscriçóes: simples dúvida pessoal. Note-se que, pelo menos, Luciano tentou apresentá-las, certamente de memória, em dialecto tessálico. 
tempo, que introduziram estes ritos e estabeleceram que, como coisa belíssima que eram, a iniciação se celebrasse com ritmo e dança. Que ainda hoje é assim (embora seja conveniente guardar silêncio a respeito dos mistérios, por causa dos não iniciados), há uma frase que toda a gente já ouviu e que muita gente repete: que aqueles que revelam cá para fora esses ritos «estão a dançar fora dos mistérios»

16. Também em Delos, nenhuns sacrifícios eram celebrados sem a dança, e, juntamente com esta, com música. Coros de jovens dançavam ao som da flauta e da cítara, uns em grupo, enquanto outros, os melhores, seleccionados de entre eles, executavam o hiporquema. Por isso, os cantos escritos para estes coros eram denominados hiporquemas, e a poesia lírica está cheia deles.

17. Mas porque estou eu a falar-te dos Gregos, quando também os Indianos, ao levantarem-se pela alvorada, adoram o Sol, não como nós, que, ao beijarmos a mão, consideramos que a nossa prece está concluída, mas, virados para oriente, saúdam o Sol com uma dança, posicionando-se em silêncio e imitando a dança do deus. É assim a prece dos Indianos, bem como a sua dança e o seu sacrifício. É deste modo que pedem duas vezes a protecção do deus: no despontar e no declinar do dia.

18. Também os Etíopes, mesmo ao lutarem, fazem-no com dança, e um guerreiro etíope não desferiria a flecha que retirou da cabeça (de facto, é desta que, em vez de aljava, eles se servem, pondo à sua volta setas dispostas em raio), sem antes executar uns passos de dança, tentando, com esta atitude, isto é, com a dança, ameaçar e, desde logo, aterrorizar o inimigo.

19. E já que fomos até à Índia e à Etiópia, vem a propósito descer, em palavras, é claro ${ }^{462}$, até ao seu vizinho Egipto. De facto, creio que a velha fábula do Proteu egípcio não quer senão significar que este foi um dançarino, uma personagem com grande poder imitativo, capaz de se transformar, de se metamorfosear em tudo, como na fluidez da água ${ }^{463}$ e na impetuosidade

462 «descer em palavra(s)» é tradução à letra; acrescento do tradutor é "é claro".

${ }^{463}$ A tradução é estritamente literal, mas também poderíamos traduzir por «a água fluida, o fogo impetuoso..., o leão feroz, o furioso leopardo, a agitada árvore». 
do fogo, pela rapidez do movimenta; na ferocidade do leáo e na fúria do leopardo; ou na agitação da árvore; enfim, em tudo o que ele quisesse. A mitologia, porém, desfigurou a natureza de Proteu no sentido do maravilhoso, e descreveu-a como se ele se transformasse em tudo aquilo que imitava. Ora, isso mesmo é característico dos modernos dançarinos, que tu poderás ver a mudar de figura rapidamente, de um momento para o outro, imitando assim o próprio Proteu. Também podemos imaginar que Empusa ${ }^{464}$, que se transformava em inúmeras figuras, era uma personagem do mesmo tipo, desfigurada pela mitologia.

20. Além destes, é justo não esquecer a dança entre os Romanos, a qual era executada pelos mais nobres de entre eles, os chamados Sálios (era este o nome da irmandade), dedicada a Ares, o mais belicoso dos deuses, e que era a mais augusta e sagrada das danças.

21. Uma lenda da Bitínia, náo muito diferente da que corre na Itália, diz que Priapo ${ }^{465}$, uma divindade bélica e, creio eu, um dos Titás ou dos Dáctilos do monte Ida, que tinha por ofício ensinar o manejo de armas, tendo recebido das mãos de Hera o deus Ares, ainda menino, embora forte e mais viril que o habitual, não o ensinou a manejar as armas, sem que primeiro fizesse dele um perfeito dançarino. Por esse serviço, ficou estabelecido que Priapo recebesse de Hera, a título perpétuo, a décima parte dos despojos de guerra que coubessem a Ares.

22. Quanto às Dionisíacas ${ }^{466}$ e às Bacanais, creio que não esperas que te diga que todas elas incluíam a dança. Eram

${ }^{464}$ V. Aristófanes, Rãs, 288, ss. Empusa, divindade do mundo subterrâneo, do séquito de Hécate, é uma espécie de papão, que aparece às mulheres e às crianças para as aterrorizar. Alimentava-se de carne humana e seduzia os humanos, mostrando-se, por vezes, na figura de uma bela jovem. Pode imaginar-se o aproveitamento dramático da personagem.

465 Priapo surge aqui, de acordo com uma lenda só transmitida por Luciano, como uma divindade bélica e mestre de armas e de dança, mas ele era conhecido e venerado sobretudo como deus da fecundidade e guarda das hortas e pomares. Era representado com um enorme falo, com que amedrontava os ladróes... De resto, Luciano, nos Diálogos dos Deuses, 3 (Loeb) apresenta Priapo com a faceta mais conhecida...

${ }^{466}$ Dionisíacas ou Dionísias, festas em honra de Dioniso, tal como as Bacanais. 
em número de três os seus géneros - o córdax ${ }^{467}$, a sicinide e a emelia -, todos inventados pelos Sátiros, ministros de Dioniso, que deram a cada um a sua designação; e foi por meio desta arte que, segundo se diz, Dioniso submeteu os Tirrenos, os Indos e os Lídios e encantou com os seus tíasos povos tão belicosos.

23. Portanto, meu maravilhoso amigo, vê lá não censures uma prática divina e mística, cultivada por tão importantes divindades e celebrada em sua honra, e que nos proporciona, ao mesmo tempo, prazer e cultura muito proveitosa.

Mas o que mais me surpreende em ti é o seguinte: sabendo eu que tu és um grande amante de Homero e de Hesíodo (e mais uma vez regresso aos poetas), como é que te atreves a contradizer esses poetas, que admiram a dança acima de tudo? De facto, Homero, ao enumerar as coisas mais agradáveis e mais belas da vida - o sono, o sexo ${ }^{468}$, o canto e a dança só a esta última caracterizou como «irrepreensível»; mas, por Zeus!, ao atribuir a qualidade de «doce» ao canto, juntam-se as duas qualidades na arte da dança: a doçura do canto e a irrepreensibilidade da dança, que tu agora deste em censurar. Noutro passo do seu poema diz:

A um a divindade ${ }^{469}$ conferiu $\|$ guerreiros feitos grandes cometer, enquanto a outro, por seu lado, deu $\|$ da dança a arte e o canto $\left[\right.$ deleitoso $0^{470}$.

De facto, é verdadeiramente deleitoso, e a mais bela dádiva dos deuses, o canto associado à dança. Parece que Homero, ao dividir todas as actividades em duas categorias - guerra e paz -, contrapôs às coisas da guerra somente estas duas, como sendo as mais belas.

${ }^{467} \mathrm{O}$ córdax (kórdax) e a sicínide (síkinnis) eram danças burlescas e, por vezes, obscenas, próprias, respectivamente, da comédia e do drama satírico; a emelia (emméleia) era uma dança mais grave mais lenta e mais comedida, adequada à gravidade da tragédia.

468 A palavra philótes, além de "amor», "amizade», "afecto», também significa "prazer sexual»; neste sentido, foi personificada: Philótes, v. dics.....; cf. expressão port. fazer amor.

469 "a divindade»: Zeus. A citação é tirada de $I l$., XIII, 730, 731 e (2o hemistíquio do $2^{\circ}$ v.) $O d .$, I, 421.

${ }^{470}$ Iliada, XIII, 720-721, a que acrescenta Odisseia, I, 421. Provavelmente, Luciano, grande leitor de Homero, está a citar de cor. 
24. Por outro lado, Hesíodo, que não ouviu de outrem, mas viu ele mesmo em pessoa as Musas dançando logo ao romper da aurora, faz-lhes, no início do seu poema, o maior dos elogios, ao dizer que

à beira duma fonte violácea, \| as Musas, com pezinhos delicados, dançam... ${ }^{471}$,

rodeando em círculo o altar de seu pai ${ }^{472}$.

Portanto, tu, meu bom amigo, ao injuriares a dança, estás como que a fazer guerra aos deuses.

25. Sócrates, o homem mais sábio (pelo menos a acreditar em Apolo Pítio, que assim o disse a seu respeito), não só elogiava a arte da dança, mas quis mesmo aprendê-la, pois considerava-a um bem inestimável pelo ritmo, pela musica, pela harmonia do movimento e pelas figuras assumidas pelos dançarinos; mesmo velho, náo se envergonhava de considerar que esta era uma das mais importantes disciplinas. Sócrates devia, sem dúvida, dar uma importância não pequena à dança, ele que não hesitava em aprender até mesmo matérias insignificantes, que não só frequentava a escola das tocadoras de flauta, mas não desdenhava de ouvir dissertar sobre assuntos sérios junto da cortesã Aspásia. E no entanto, Sócrates assistia a uma arte que, nesse tempo, estava somente a começar e ainda não tinha atingido um elevado grau de organização. Se ele visse actuar aqueles que, nos nossos dias, a elevaram ao mais alto grau de perfeição, estou convencido de que abandonaria todas as suas actividades, se dedicaria exclusivamente a este espectáculo e não ensinaria aos jovens nenhuma outra matéria antes desta.

26. Creio que, ao elogiares a comédia e a tragédia, te esqueces de que em cada uma delas há um género de dança específico, ou seja, a emelia ${ }^{473}$ na tragédia, e o córdax na comédia, a que por vezes se acrescenta um terceiro género, a sicinide. Mas já que, no princípio, preferiste à dança a tragédia, a comédia, os

471 Teogonia, 3-4.

472 Teogonia, 3-4. Luciano continua a citar Hesíodo, mas sob a forma de paráfrase.

${ }^{473} \mathrm{~V}$. nota ao $\$ 22$. 
flautistas ambulantes e a citarédia ${ }^{474}$, géneros próprios para entrar em concursos e que, por isso, tu consideraste respeitáveis, pois entấo examinemos cada um deles em confronto com a dança. No entanto, se estás de acordo, deixemos de lado a flauta e a cítara, pois fazem parte da função do dançarino.

27. No que respeita à tragédia, examinemos bem, a começar pela forma exterior, como ela se apresenta, como é um espectáculo horrível e aterrador, esse de ver uma personagem aparamentada para aparentar uma altura desproporcionada, montada sobre coturnos altíssimos, com uma máscara que apanha toda a cabeça, com uma enorme boca escancarada, como se quisesse engolir os espectadores, para já não falar dos enchumaços no peito e na barriga, acrescentando uma corpulência postiça e artificial, para que a altura desproporcionada náo fique claramente ridícula num corpo muito magro; depois, clamando de dentro da máscara, arqueando-se todo, ora para trás, ora para a frente, algumas vezes recitando versos jâmbicos e - o mais vergonhoso de tudo - cantando as suas desventuras e somente responsável pela sua voz, pois o resto foi tarefa dos poetas que viveram muito tempo antes. Enquanto se trata de uma Andrómaca ou de uma Hécuba, o canto é suportável; mas quando é Héracles que irrompe pela cena declamando uma monódia, esquecido de quem é e sem respeito nem pela pele de leão, nem pela moca que usa, qualquer pessoa, no seu juízo perfeito, certamente classificaria essa actuação como um... solecismo ${ }^{475}$.

28. De resto, aquilo que tu censuras na dança, ou seja, o facto de serem homens a fazer o papel de mulheres, seria um defeito comum à tragédia e à comédia; nestas duas, as mulheres até são em número superior aos homens.

29. A comédia, por seu lado, considera mesmo o carácter burlesco das suas personagens como parte do seu encanto, caso de figuras como, por exemplo, os Davos ${ }^{476}$, os Tibios e os cozinheiros.

474 kitharoidia "cítara e canto", "canto acompanhado à cítara» (ou lira).

${ }^{475} \mathrm{O}$ termo solecismo, gr. soloikismôs (em Luciano, também soloikía) refere-se propriamente a grosseiros erros de gramática ou de linguagem em geral, barbarismos, mas também pode aplicar-se a outros domínios, como a arte dramática...

476 Trata-se de personagens da chamada «Comédia Nova». Davo, gr. $\Delta \hat{\alpha}$ os, lat. Dauos, e Tibio, gr. Tíßeıos, lat. Tibius (mas também gr. post. 
No que respeita à apresentação exterior do dançarino, não preciso de dizer como é decente e decorosa, coisa que só não vê quem é cego. Quanto à máscara, propriamente, é belíssima e bem adequada ao motivo da peça, sem a boca escancarada, como as outras, mas fechada, pois [o dançarino] tem muitas personagens a cantar por ele.

30. Em tempos recuados, é verdade, os próprios cantavam e dançavam, mas posteriormente, como a respiraçáo afogueada dos dançarinos perturbava o canto, entendeu-se que era preferível que fossem outros a acompanhar com o canto.

31. Quanto aos temas, eles são comuns a ambos os géneros, os da dança não diferem em nada dos da tragédia, a não ser pelo facto de os daquela ${ }^{477}$ serem mais variados, mais eruditos ${ }^{478}$ e conterem variadíssimas mudanças de situação.

32. Se a dança não faz parte de concursos, isso deve-se digo eu - ao facto de os agonótetas ${ }^{479}$ entenderem que esse género era demasiado importante e demasiado respeitável para ser submetido a competição ${ }^{480}$. Náo preciso de dizer que uma cidade da Itália, a mais ilustre da raça calcídica ${ }^{481}$, acrescentou a dança aos jogos que nela se realizavam, como elemento de maior prestígio.

33. Desejo, aqui e agora, dar-te uma justificação pelo facto de, nesta minha exposição, ter omitido muitíssimos factos, para que não dê a impressão de ser ignorante ou inculto. De facto, não desconheço que muitos, que, antes de nós ${ }^{482}$, deixaram

Tíßıৎ, de esquema dactílico, donde eventualmente port. Tibio) são nomes de escravos da comédia, figuras burlescas. Note o uso depreciativo do plural: os Davos e os Tibios.

${ }_{477}$ Ou seja, os temas da dança.

478 "mais eruditos», é a traduçâo óbvia de polümathésterai, o que pode parecer estranho. O editor da Loeb traduz por more unhackneyed «mais originais»; talvez «mais refinados», por se basearem em versôes menos conhecidas de certos mitos - o que era caso frequente. Daqui que, afinal, a interpretação por «mais eruditos» não seja de todo estranha.

${ }^{479}$ Os agonothétai eram os organizadores, presidentes e, também, árbitros dos jogos e concursos.

${ }^{480}$ Naturalmente, esta justificação não nos convence...

${ }^{481}$ Trata-se de Nápoles, cidade fundada por colonos da Cálcida, na Eubeia.

482 «antes de nós», plural 'majestático' = «antes de mim». 
obras sobre a dança, consagraram a maior parte do seu tempo à sua elaboração, percorrendo todos os géneros de dança e catalogando os nomes de cada uma, as suas características e por quem cada uma fora inventada, cuidando de fazer prova de grande erudição nesta matéria. Pela minha parte, porém, creio bem que uma tal actividade constituiria uma presunção insensata, serôdia e imprópria da minha pessoa, e por isso mesmo passo adiante.

34. Além disso, peço-te uma coisa: que tenhas sempre em mente e te lembres de que, neste momento, não se trata de fazer a genealogia da dança, nem é meu propósito, neste escrito, fazer uma enumeração completa das formas de dança, a não ser daquelas poucas que, no início, eu recordei, mas mencionando apenas as principais. Ora, de momento, o principal objectivo deste meu escrito é o seguinte: fazer o elogio da dança como ela actualmente se apresenta e mostrar tudo o que de encantador e útil ela reuniu e possui, ela que atingiu uma notável perfeição, não nos tempos antigos, quando começou, mas sobretudo na época de Augusto ${ }^{483}$.

$\mathrm{Na}$ verdade, as primitivas manifestaçóes eram como que as raízes e as bases da dança, mas é sobre as suas flores e, portanto, do fruto maduro que neste momento culminou na sua máxima perfeição, que o meu discurso se desenvolve, deixando de lado a «dança das tenazes» ${ }^{444}$, a «dança dos grous» e outras, que já não têm nada que ver com a dança moderna. Quanto ao género de dança chamado frígio, próprio para acompanhar bebedeiras e festins e executado sob o efeito da embriaguez por rudes campónios, que geralmente dançam com acompanhamento de flauta tocada por mulheres e executam saltos violentos e fatigantes, género que ainda hoje subsiste nos meios rurais, não foi por ignorância que

${ }^{483}$ Luciano refere-se às pantomimas, levadas a grande perfeição por dois libertos do tempo de Augusto, os pantomimos Batilo de Alexandria, protegido de Mecenas, e Pílades da Cilícia. Apesar da sua designação grega ( $\pi \alpha \nu \tau$ ó $\mu \iota \mu \circ \varsigma$, lit. $^{\text {te }}$ "imitaçáo de tudo»), a pantomima, tal como a sátira, era genuinamente romana.

${ }^{484}$ A «dança das tenazes» (thermaustrís), muito violenta, incluía saltos em que os pés, muito elevados, batiam uns nos outros; era uma espécie de acrobacia artística; "dança dos grous» (géranos) imitava um bando de grous em fuga e representava a evasão do Labirinto de Creta. Pouco mais sabemos a respeito de ambas, pois, mesmo para os antigos (desde, pelo menos, o tempo de Luciano), quase se havia perdido a sua memória. 
eu o omiti, mas pelo facto de nada ter de comum com a dança moderna. Na verdade, Platão, nas Leis, elogia certos géneros de dança, mas reprova vivamente outros, dividindo-os. por um lado, em géneros agradáveis e úteis, e, por outro lado, rejeitando de entre eles os indecentes, com preferência e admiração pelos outros.

35. Mas, a respeito da dança, propriamente, é quanto basta. Realmente, seria insensatez alongar o discurso, descrevendo todos os aspectos. Proponho, sim, desde já, descrever que qualidades deve possuir o dançarino, como deve exercitar-se, que matérias deve aprender e com que meios deve aperfeiçoar o seu trabalho, para que fiques a saber que esta não é uma dessas artes fáceis e que se executam sem preparação, mas, pelo contrário, atinge o ponto mais alto de todas as ciências: não só a música, mas também a rítmica, a métrica, muito em especial a tua querida filosofia, a física e a ética. É certo que a dança tem considerado a dialéctica como uma matéria desajustada e inútil para si, Ora, ela não está assim táo afastada da retórica, mas tem de comum com esta a capacidade de descrever os costumes e as paixóes, coisa a que também os oradores aspiram. Nem está afastada da pintura e da escultura, mas parece claramente imitar o sentido da proporção que existe nestas duas, de tal modo, que não creio que Fídias ou Apeles lhe sejam superiores.

36. Antes de mais, deve tornar propícias a si Mnemósine ${ }^{485} \mathrm{e}$ sua filha Polímnia, e recordar-se de tudo. De facto, à semelhança do Calcante ${ }^{486}$ de Homero, convém que o dançarino conheça

... o que é, || o que será e aquilo que antes fo $i^{487}$,

de forma que náo lhe escape nada, mas que tenha uma memória pronta e fiel ${ }^{488}$. Mas o principal desta profissáo consiste numa certa ciência mimética, demonstrativa, explicativa do que se quer significar e elucidativa do que é obscuro, e ainda

${ }^{485}$ Mnemósine, a Memória, mãe das Musas.

${ }^{486}$ Calcante ou, com base no nominativo, Calcas. Trata-se do famoso adivinho, que acompanhou os gregos na expedição contra Tróia.

${ }^{487}$ Ilíada, I, 70. Ou seja: "O presente, o futuro e o passado».

488 "pronta e fiel» pretende traduzir um único adjectivo: prókheiros, "perto da mão», «rápido», «fácil», «natural»... 
aquilo que Tucídides disse a respeito de Péricles, ao elogiar este homem, quer dizer, o mais alto louvor que pode fazer-se a um dançarino: "conhecer 0 assunto e saber interpretá-lo» ${ }^{489}$. Por saber interpretá-lo eu entendo, no caso presente, a clareza dos gestos. Mas toda a matéria-prima desta arte está, conforme já disse, na história antiga ${ }^{490}$, na sua evocação pronta e fiel ${ }^{491}$ e na sua representação com dignidade.

37. Portanto ${ }^{492}$, começando logo pelo Caos e pela primitiva génese do mundo, deve conhecer todos os factos até à história da egípcia Cleópatra. Sim, a erudição do dançarino deve, em nosso ${ }^{493}$ entender, abarcar todo este período, e ele deve conhecer bem os episódios entre essas datas: a castração de Úrano; o surgimento ${ }^{494}$ de Afrodite; a luta dos Titás; o nascimento de Zeus; a astúcia de Reia e a substituição [de Zeus] por uma pedra; as grilhetas de Crono; a partilha entre os três irmãos ${ }^{495}$.

38. Depois, por ordem, a revolta dos Gigantes; o roubo do fogo; a criação do homem; a punição de Prometeu; o poder de um e de outro $\operatorname{Eros}^{496}$; a seguir, a errância [da ilha] de $\operatorname{Delos}^{497}$; o parto

489 Tuc., II, 60, 5.

${ }^{490}$ Naturalmente, Luciano não se refere à História, propriamente dita, mas à mitologia, como, de resto, se vê pela sequência da exposição.

491 "pronta e fiel» pretende traduzir um único adjectivo: prókheiros, "perto da máo», «rápido», "fácil», «natural»...

492 Começa aqui uma resenha da história mitológica, apresentada por simples tópicos, mas, mesmo assim, bastante extensa (\$\$ 37-61).

493 "nosso", plural 'majestático' = «meu».

${ }^{494}$ Segundo a tradição corrente, Afrodite nasceu das ondas do mar: Crono cortou os órgãos sexuais de seu pai Úrano, os quais, ao caírem no mar, geraram a bela deusa do amor.

${ }^{495}$ Assim como Úrano fora expulso por seu filho Crono, também este foi expulso por Zeus, o qual, no entanto, resolveu dividir o universo com os seus dois irmãos: Zeus escolheu para si o céu e o poder supremo; a Posídon coube o império dos mares; e Hades (Plutão) ficou com o reino dos mortos.

496 Eros e Ânteros, "Amor» e "Anti-amor», este último muito menos conhecido; eram irmáos, ambos filhos de Afrodite e Ares; Ânteros personifica o amor infeliz; Chegaram até nós baixos-relevos, em que os dois irmãos são representados a lutar um contra o outro.

${ }^{497}$ A ilha de Delos foi o lugar de nascimento de Apolo. Sua mãe, Leto (ou Latona), em busca desesperada de um lugar para dar à luz, foi ter a uma ilha flutuante e estéril, chamada Ortígia, nome depois mudado em Delos («a brilhante»); a ilha foi definitivamente fixada, e marcava o centro (o umbigo) do mundo. 
de Leto ${ }^{498}$; a morte de Píton; a conspiração de Tício ${ }^{499}$; a descoberta do centro da Terra por meio do voo das [duas] águias.

39. A seguir a estes, Deucalião, o grande naufrágio da vida no tempo deste, e a arca, a única que preservou o que restava do género humano; e os homens novamente gerados de pedras; depois, o despedaçamento de Iaco; o dolo de Hera; a fulminação de Sémele ${ }^{500}$; os dois nascimentos de Dioniso ${ }^{501}$; os episódios relativos a Atena, a Hefesto e a Erictónio; a disputa da Ática; Halirrótio e o primeiro julgamento no Areópago; numa palavra, toda a mitologia ática.

40. Mas muito especialmente as errâncias de Deméter, o reencontro com Core, a hospitalidade de Celeu, a agricultura inventada por Triptólemo, a cultura da vinha inventada por Icário, as desventuras de Erígone, os episódios passados com Bóreas, com Oritia, com Teseu e com Egeu; depois, a recepção de Medeia e a sua posterior fuga para a Pérsia, a história das filhas de Erecteu e das filhas de Pandíon, o que elas sofreram e fizeram na Trácia; a seguir, Acamante ${ }^{502}$ e Fílide, o primeiro rapto de Helena ${ }^{503}$ e a expediçăo dos Dioscuros contra a cidade; e a desgraça de Hipólito, e o regresso de Héracles, pois todas estas histórias podem ser consideradas como propriamente áticas.

${ }^{498}$ Leto $(\Lambda \eta \tau \omega ́)$ ou Latona (designação latina).

499 Titüós, gigante, filho de Geia (a Terra), tentou violar Leto, pelo que foi fulminado por Zeus e precipitado no Tártaro, onde duas serpentes (ou duas águias) lhe devoravam perpetuamente o fígado, que voltava a crescer.

500 Sémele, amante de Zeus, de que nasceu Dioniso, foi vítima do dolo de Hera, esposa legítima de Zeus, pois, por dolosa sugestão desta, pediu a Zeus que se lhe mostrasse em todo o seu esplendor. O deus acedeu, pelo que Sémele morreu completamente carbonizada.

${ }^{501}$ Sémele, por manhosa sugestão de Hera, esposa traída, pediu a Zeus que se lhe revelasse em todo o seu esplendor. Foi fulminada por contemplar directamente o brilho de Zeus. Grávida de seis meses, Zeus retirou-lhe o feto e introduziu-o na própria coxa, até completar os nove meses. Daí os «dois nascimentos» de Dioniso.

502 Acamante ou Ácamas, um dos combatentes contra Tróia; Fílide torna-se mais tarde sua esposa, na sequência de uma história que Luciano, naturalmente, se dispensa de narrar.

${ }^{503} \mathrm{O}$ primeiro rapto de Helena, ainda donzela (ignorado por Homero) foi cometido por Teseu, tendo Helena sido libertada pelos Dioscuros (Castor e Pólux). O segundo rapto é o da epopeia homérica, quando Helena foi raptada por Páris (Alexandre) e levada para Tróia. 
Mencionei, a título de exemplo, apenas um reduzidíssimo número de histórias, de entre muitas outras que deixei de lado.

41. A seguir, temos Mégara, Niso e Cila, a cabeleira purpúrea, a viagem de Minos e a ingratidão deste para com a sua benfeitora; seguidamente, vem Citéron ${ }^{504}$, as desventuras dos Tebanos e dos Labdácidas, a viagem de Cadmo, o repouso da vaca, os dentes de serpente e o surgimento dos Espartos ${ }^{505}$ e a metamorfose de Cadmo em serpente, as muralhas erguidas ao som da lira, a loucura do seu arquitecto e a soberba de Níobe, sua esposa, e o seu silêncio doloroso, a história de Penteu, de Actéon, de Édipo e de Héracles, com todos os seus trabalhos e o massacre dos seus filhos;

42. Depois vem Corinto, também cheia de mitos, que tem Glauca e Creonte, e, antes destes, Belerofonte, Estenobeia, a disputa entre Hélio e Posídon, e, posteriormente, a loucura de Atamante ${ }^{506}$, a fuga dos filhos de Néfele montados num carneiro,... ${ }^{507}$ e a recepção [entre os deuses marinhos] de Ino e Melicertes.

43. A seguir a estes, a história dos Pelópidas, Micenas e os episódios nela acontecidos, e, antes disso, Inaco, Io e o guarda desta, Argos; e Atreu, Tiestes, Aérope, o velo de oiro, o casamento de Pelopeia ${ }^{508}$, o assassinato de Agamémnon e a punição de Clitemnestra; muito antes destes factos, a expediçáo dos sete chefes, a recepção dos genros de Adrasto exilados e o oráculo a respeito destes, a proibição de serem sepultados e, na sequência disso, a morte de Antígona e de Meneceu.

44. E também o que se passou em Nemeia, a história de Hipsípile e a de Arquémoro, tudo isso deve obrigatoriamente constar da memória do dançarino; e, antes desses tempos, deve conhecer o estado de virgindade [forçada] de Dánae, o nascimento

${ }^{504}$ Rei de Plateias, deu o nome ao monte Citéron, entre a Beócia e a Ática.

505 Spartói, lit. "te "semeados", refere-se aos Tebanos, que nasceram dos dentes de uma serpente (ou de um dragão) semeados por Cadmo.

${ }^{506}$ Atamante ou Átamas, rei de Queroneia (ou Tebas), tem uma história muito variada, que serviu de tema a diversas tragédias. A loucura aqui referida é apenas a mais trágica da história do herói: ferido de loucura por Dioniso, matou seu filho mais novo, Learco, lançando-o num caldeirão de água a ferver.

${ }^{507}$ Neste ponto, os mss. têm uma lacuna.

${ }^{508}$ Pelopeia $(П \varepsilon \lambda o ́ \pi \varepsilon \imath \alpha)$, filha de Pélias, ou, aqui, filha de Tiestes; os mss. têm a lição Пع $\lambda$ o $\pi \dot{i} \alpha$, Pelópia, filha de Tiestes, mãe de Egisto... 
de Perseu e a luta que lhe foi proposta contra as Górgonas, com a qual se relaciona a narrativa etiópica; e as personagens de Cassiopeia, Andrómeda e Cefeu, que posteriormente a credulidade dos homens colocou no número dos astros; também deve conhecer a velha história de Egipto e Dánao e a conspiração nupcial [das Danaides] ${ }^{509}$.

45. A Lacedemónia também oferece não poucas histórias deste género: Jacinto e Zéfiro, rival de Apolo, a morte do jovem atingido pelo disco, a flor que brotou do seu sangue e a inscrição aiante nela inscrita ${ }^{510}$; e a ressurreição de Tindáreo ${ }^{511} \mathrm{e}$, por este facto, a cólera de Zeus contra Asclépio; depois, a recepção feita a Páris e o rapto de Helena, a seguir à sentença sobre a maçã ${ }^{512}$.

46. Na verdade, há que considerar que à história de Esparta se liga a de Ílion, tão longa e com tantas personagens. É que, por cada um dos que ali tombaram, resulta um drama para a cena. Então, o dançarino deve ter muito bem presentes esses temas, desde o rapto [de Helena] até aos episódios que aconteceram quando do regresso [dos guerreiros], bem como as errâncias de Eneias e a paixão de Dido.

Não são alheios a estas histórias os episódios dramáticos ocorridos com Orestes, bem como as façanhas deste herói na Cítia, como também não são fora de propósito os episódios anteriores, mas relacionados com a guerra de Tróia: o disfarce virginal de Aquiles em Ciros, a fúria de Ulisses, o abandono de Filoctetes, enfim, todas as errâncias de Ulisses; e Circe, Telégono, a soberania de Éolo sobre os ventos, e todos os outros

${ }^{509}$ As cinquenta filhas de Dánao, que casaram com os seus cinquenta primos, filhos de Egipto. Na noite de núpcias, todas elas (com excepção da mais velha, Hipermnestra) mataram os respectivos maridos.

510 «aiante», ou "gemebunda»: o grego diz aiázousa, lit. "te "que diz ai-ai», "gemebunda»; aiante, do v. aiar, pouco usado em português, mas, neste caso, pouco menos que inevitável. Os antigos viam na flor do jacinto as duas letras AI, que interpretavam como sendo a referida «inscrição aiante».

511 Tindáreo parece ser forma preferível a Tíndaro...

512 Éris (a Discórdia), despeitada por náo ter sido convidada para o banquete dos deuses, vingou-se, lançando na sala uma maçã de oiro com a inscrição "para a mais bela». Candidataram-se naturalmente Atena, Hera e Afrodite, que escolheram para juiz o filho mais novo de Príamo, rei de Tróia, de nome Páris ou Alexandre. Este elegeu Afrodite rainha de beleza, a qual the havia prometido dar-lhe Helena, esposa de Menelau, rei de Esparta. Daqui se gerou a guerra de Tróia. 
acontecimentos, até ao castigo dado aos pretendentes; ainda antes disso, a conspiração contra Palamedes, a cólera de Náuplio, a loucura de Ájax e a morte do outro Ájax nos rochedos.

47. Também a Élide tem muitos motivos para os que querem exercitar-se na dança: Enómao, Mírtilo, Crono, Zeus e os primeiros lutadores dos Jogos Olímpicos;

48. Abundante é também a mitologia da Arcádia: a fuga de Dafne, a metamorfose de Calisto em fera ${ }^{513}$, a embriaguez dos Centauros, o nascimento de Pá, a paixão de Alfeu e a sua viagem submarina.

49. E se — nem que seja só em fantasia ${ }^{514}$ — , fores até Creta, também aí a dança faz uma abundante colheita: Europa, Pasífae, os dois touros ${ }^{515}$, o labirinto, Ariadne, Fedra, Andrógeo, Dédalo, Ícaro, Glauco, a arte divinatória de Poliido ${ }^{516}$, e Talo, o vigilante de bronze de Creta.

50. E se fores até à Etólia, também aí a dança fornece abundante material: Alteia, Meléagro, Atalanta ${ }^{517}$, o brandão, a luta de Héracles contra o rio, o nascimento das Sereias, o surgimento das Equínades ${ }^{518}$ e o estabelecimento nelas de Alcméon, passada a sua loucura; depois, Nesso e o ciúme de Dejanira e, na sua sequência, a pira no Eta.

51. Também a Trácia tem muito material necessário a quem pretenda entrar na arte da dança: Orfeu, o seu desmembramento e a sua cabeça falante flutuando sobre a lira; Hemo, Ródope, o suplício de Licurgo;

52. A Tessália fornece ainda mais material: Pélias, Jasão, Alceste, a expedição dos cinquenta jovens, o navio Argo e a sua quilha falante;

${ }^{513}$ Luciano diz, genericamente, "em fera»; é claro que, nestes simples tópicos, contava com suficiente cultura mitológica dos aprendizes de dançarino, que tinham obrigação de saber que se tratava de «ursa».

514 «em fantasia»: o texto diz «em palavra», que se oporia a «em acto».

515 Trata-se do Minotauro e do touro que o gerou.

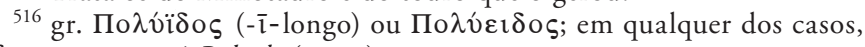
a forma port. será Poliido (grave).

517 Atalanta ou Atalante.

${ }^{518}$ Equínades ou Equinas, ninfas transformadas em ilhas. 
53. Depois os episódios de Lemnos, Eetes, o sonho de Medeia, o desmembramento de Apsirto, os acontecimentos durante a travessia e, depois disso, Protesilau e Laodamia.

54. E se daqui passares novamente para a Ásia, também aí há muitas histórias dramáticas: para começar, Samos, com a tragédia de Polícrates e as errâncias de sua filha até à Pérsia; e histórias ainda mais antigas, como a indiscrição de Tântalo, o banquete oferecido aos deuses em sua casa, a preparação culinária da carne de Pélops e a sua espádua de marfim.

55. Na Itália, temos o [rio] Erídano, Faetonte e suas irmãs metamorfoseadas em choupos e chorando, vertendo lágrimas de âmbar.

56. Um tal dançarino conhecerá também as Hespérides, o dragão guarda das maçãs de oiro, o trabalho de Atlas, Gérion e o roubo dos bois [da ilha] de Eritia.

57. Também não desconhecerá todas as metamorfoses míticas: pessoas transformadas em árvores, ou em feras, ou em aves, e outras que, de mulheres, se transformaram em homens: refiro-me a Ceneu, a Tirésias e outros que tais.

58. Da Fenícia, o dançarino também deve conhecer Mirra e o famoso luto alternado ${ }^{519}$ da lenda síria ${ }^{520}$, bem como os acontecimentos mais recentes, como as façanhas realizados por Antípatro após o domínio macedónico, e, na corte de Seleuco, a paixão [de Antíoco $\left.{ }^{521}\right]$ por Estratonice.

59. Quanto aos rituais do Egipto, algo secretos como são, o dançarino deve, sim, conhecê-los, mas interpretando-os de forma

${ }^{519}$ Refere-se a Osíris, antigo rei do Egipto, o qual, depois da sua morte, passou a fazer parte dos deuses. Presidia ao dia luminoso, mas todas as noites era morto por Tifão, personificação das trevas. Então a divina Ísis subia ao céu, percorrendo-o com o crescente luminoso, à procura do seu esposo, que ela, finalmente, encontrava ao romper da aurora.

${ }^{520} \mathrm{O}$ texto diz «assíria», confusão corrente.

${ }^{521}$ Naturalmente, Luciano não nomeia o amante, pois apenas pretende, aqui como em toda a longa sinopse, dar alguns apontamentos mitológicos. Antíoco era filho de Seleuco, antigo general de Alexandre e, posteriormente, rei da Síria; Estratonice era a esposa de Seleuco, por quem Antíoco se apaixona... história picante, apta para ser coreografada. 
mais simbólica ${ }^{522}$ : refiro-me a Épafo, a Osíris e às metamorfoses dos deuses em animais. Mas, antes de mais, deve conhecer os episódios amorosos dos deuses, sobretudo de Zeus e tudo aquilo em que este se disfarçou ${ }^{523}$;

60. Também [deve conhecer] toda a tragédia do Hades, os suplícios e as causas de cada um deles, a amizade de Pirítoo e Teseu até no reino de Hades.

61. Para dizer em poucas palavras, não deve ignorar nada do que foi escrito por Homero, por Hesíodo e pelos melhores poetas, especialmente os trágicos.

De entre tantas, melhor, de entre a multidão infinita de histórias, seleccionei apenas estas, as mais importantes, deixando as outras para os poetas cantarem, para os dançarinos representarem e para tu descobrires outras mais, por associação com as que ficam acima mencionadas, histórias essas, que obrigatoriamente o dançarino deve ter à máo, preparadas e armazenadas para utilizar cada uma em ocasiáo oportuna.

62. Ora, uma vez que a sua arte é imitativa e lhe compete interpretar por gestos aquilo que outros cantam ${ }^{524}$, é imprescindível que o dançarino, à semelhança dos oradores, exercite a clareza, de forma que cada episódio por ele executado seja entendido sem necessidade de intérprete, mas antes, como disse o oráculo pítico, quem assista a uma dança deve compreender um mudo e ouvir o que o dançarino diz sem falar.

63. Foi isso mesmo que, segundo se diz, aconteceu com Demétrio, o cínico ${ }^{525}$. De facto, este, tal como tu, censurava a dança, dizendo que o dançarino era um elemento acessório da flauta, das siringes e dos batimentos de pés, que nada acrescentava à acção, que

${ }^{522}$ Luciano entende que, em certos casos, há que evitar representações demasiado realistas ou literais, pelo que o dançarino deve substituir a metamorfose pela sugestão gestual.

523 Só a extensa crónica amorosa de Zeus daria matéria para muitas dezenas de representaçóes.

${ }^{524}$ Esta informação é muito importante: o dançarino só representa o que outros cantam (... e tocam).

${ }^{525}$ Este Demétrio viveu em Roma no tempo de Gaio, Nero e Vespasiano. Em 66 d.C. (tempo de Nero), foi expulso para a Grécia, mas voltou posteriormente a Roma. 
o seu movimento era simplesmente falho de sentido e inútil, pois não continha em si mesmo qualquer significado, que as pessoas é que se deixavam seduzir pelos acessórios da acção, pelas vestes de seda e pela beleza das máscaras, pela flauta e seus requebros, bem como pela voz harmoniosa dos cantores, tudo elementos para embelezar, mas que náo têm que ver com a arte do dançarino. Então, um dançarino muito famoso do tempo de Nero, homem, segundo se diz, nada falho de inteligência e que sobressaía de todos os outros pela memorização da história mitológica e pela beleza dos seus movimentos, fez um pedido a Demétrio, um pedido, na minha opiniāo, muito razoável: que primeiro o visse dançar, e só depois o censurasse; e prometeu que iria representar para ele sem o acompanhamento nem de flauta nem de cantos. E assim fez. Tendo pedido silêncio aos acompanhantes da percussáo, aos tocadores de flauta e ao próprio coro, dançou, sem acompanhamento, o adultério de Afrodite e Ares, a denúncia feita por Hélio, a cilada montada por Hefesto e ambos os amantes, Afrodite e Ares, presos na rede, e depois os deuses a virem assistir, um por um, e Afrodite muito envergonhada, e Ares apavorado e suplicante, enfim, todos os pormenores desta história, de tal modo, que Demétrio, encantado com a actuação, fez o maior elogio que se pode fazer a um dançarino; elevou a voz e gritou a plenos pulmóes: «Ó homem! Eu oiço o que tu fazes, e não vejo apenas, pois tenho a impressão de que tu falas com as próprias mãos.»

64. Mas já que estamos, em conversa, no tempo de Nero, quero contar-te o que se passou com um bárbaro a respeito do mesmo dançarino, facto esse que constitui o maior dos elogios que se podem fazer à arte da dança. Foi o caso que um bárbaro do Ponto, personalidade de família real, tendo vindo à corte de Nero para tratar de qualquer assunto, assistiu, entre outros espectáculos, ao desse tal dançarino, o qual executava a dança com tal clareza, que, embora não estivesse atento à letra da canção — pois acontecia que era só meio grego — , percebia tudo. Ora, quando estava já mesmo para regressar à sua pátria, como Nero, ao despedir-se dele, lhe dissesse que pedisse o que entendesse, que prometia dar-lho, disse: «Se me ofereceres o dançarino, dar-me-ás o maior prazer». E tendo Nero perguntado "Que utilidade teria ele na tua terra?", respondeu: "Tenho vizinhos bárbaros, que não falam a mesma lingua que eu, e não é fácil conseguir intérpretes 
para tratar com eles; portanto, sempre que eu precisar de um, este homem traduzirá tudo por mim através dos gestos». Eis, pois, a que ponto o impressionou o poder de imitaçáo da dança, que lhe pareceu muito expressivo e claro.

65. A maior tarefa e o principal objectivo da arte da dança consiste, conforme já disse, na representaçáo, executada da mesma maneira que o fazem os oradores, muito especialmente aqueles que recitam as peças agora chamadas declamaçóes ${ }^{526}$. Ora, não há coisa que mais elogiemos nos dançarinos, do que o seu poder de identificação com as personagens representadas e o facto de não serem destoantes as falas dos heróis, dos tiranicidas, dos pobres ou dos rústicos que entram em cena, mas antes, a representação de cada um deles com as suas características próprias e distintivas.

66. Quero ainda contar-te o que disse um bárbaro a este respeito. De facto, tendo visto cinco máscaras próprias para dançarinos (pois a peça tinha esse número de actos), e vendo um único dançarino, perguntou quem eram os dançarinos seguintes que iam interpretar os restantes papéis. Então, ao ser informado de que o mesmo dançarino ia interpretar e dançar todos os papéis, disse: "Meu amigo, não sabia que tu, num só corpo, tinhas muitas almas». Assim falou o bárbaro.

67. Não é sem razão que os Italiotas ${ }^{527}$ chamam ao dançarino "pantomimo", designação tirada justamente da acção por ele executada ${ }^{528}$. Na verdade, é excelente e necessário ao dançarino o famoso conselho do poeta ${ }^{529}$ : "Meu filho, adquire o modo do animal marinho das rochas ${ }^{530}$, e então entende-te com todas as cidades» ${ }^{531}$; assim, ele deve aplicar-se aos temas e identificar-se com cada uma das acçóes.

${ }^{526} \mathrm{O}$ termo grego $\mu \varepsilon \lambda \varepsilon \dot{\varepsilon} \tau \boldsymbol{\imath}$ (melétai) é aqui o equivalente do lat. declamationes, que eram exercícios de retórica ou discursos sobre temas teóricos...

527 Luciano refere-se ao gregos das colónias da Magna Grécia; apesar da designação grega, a origem destas representaçóes é itálica.

528 "pantomimo", gr. $\pi \alpha \nu \tau o ́ \mu t \mu o \zeta$, significa "que imita tudo».

${ }^{529}$ Luciano cita (parece que de memória, pois a citação não é exacta) um passo de Píndaro, Fr. 43 (173) Schroeder (apud ed. Loeb).

${ }_{530}$ Quer dizer: o polvo.

${ }^{531}$ Luciano cita (parece que de memória, pois a citação não é exacta) um passo de Píndaro, Fr. 43 (173) Schroeder (apud ed. Loeb). 
De um modo geral, a dança propóe-se mostrar e interpretar [personagens], introduzindo ora um apaixonado, ora alguém furioso, ora um louco, ora outro amargurado, e tudo isso em diversas tonalidades. Mas o mais espantoso de tudo é o facto de vermos o dançarino representar, no mesmo dia, ora Atamante furioso, ora Ino temerosa, ora Atreu em pessoa, e pouco tempo depois Tiestes, e a seguir Egisto ou Aérope, e todos esses papéis são representados por um único homem.

68. Ora, as outras artes, visuais ou auditivas, envolvem, cada uma por si, a exibiçáo de uma só actividade: ou a flauta, ou a cítara, ou uma melodia vocal, ou uma representação trágica, ou uma jocosidade cómica, ao passo que o dançarino abarca todas estas artes, e podemos ver nele uma preparação variada e mista: a flauta, a siringe, o batimento de pés, o tanger do címbalo, a melodia do actor e a harmonia dos cantores.

69. Além disso, cada uma dessas outras actividades diz respeito a uma das duas partes do ser humano - a alma e o corpo - , ao passo que, na dança, estão ambas misturadas. De facto, a acçáo contém em si a exteriorização do espírito e a força do exercício físico, e ainda - a coisa mais importante — a arte de representar, sem qualquer incongruência relativamente ao texto. Por isso é que Lebónax de Mitilene, homem de excelsas virtudes ${ }^{532}$, chamava aos dançarinos "quirósofos» ${ }^{533}$, e costumava ir assistir às suas exibições, no intuito de regressar do teatro mais perfeito. Também Timócrates, seu mestre, ao ver pela primeira vez, e sem ir assistir de propósito, um dançarino executando a sua arte, exclamou: "De quão importante espectáculo me tem privado o respeito pela filosofia!».

70. Se é verdade o que Platão $0^{534}$ diz a respeito da alma, o dançarino revela magnificamente as suas três partes: a irascível, quando representa uma personagem furiosa, a concupiscente, quando interpreta personagens apaixonadas, e a racional, quando póe um freio a cada uma das paixóes. Esta última qualidade encontra-se disseminada por todas as partes da dança, como

${ }^{532}$ Trata-se do famoso $\kappa \alpha \lambda$ ò $\varsigma \alpha \alpha \grave{\alpha} \alpha \gamma \alpha \theta$ ó, sempre difícil de traduzir...

${ }^{533}$ Lit. $^{\text {te }}$ "sábios de mãos», "hábeis na arte de representar com as máos». A ed.

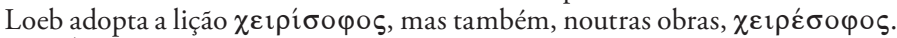

${ }^{534}$ Rep., IV, 436-441. 
o tacto por todos os sentidos. Ora o dançarino, ao propor-se atingir a beleza e a harmonia nas suas evoluçóes, que outra coisa está a comprovar, senão aquilo que disse Aristóteles ${ }^{535}$, ao elogiar a beleza, e ao considerar esta como sendo a terceira parte do bem?

Uma vez, ouvi alguém falando entusiasticamente e até com um certo exagero a respeito do silêncio das personagens da dança, dizendo que esse silêncio simboliza um dogma pitagórico.

71. Além disso, enquanto todas as outras actividades nos prometem, umas o prazer, outras a utilidade, a dança é a única que contém ambos os bens, e tanto mais que a utilidade se produz juntamente com o prazer. Sim, quanto mais agradável náo é este espectáculo, do que ver jovens esmurrando-se, escorrendo sangue, e outros lutando no meio do pó! Tais personagens, a dança mostra-as, de facto, muitas vezes, mas de maneira mais segura, mais bela e mais agradável. Além disso, sucede que o movimento tenso da dança, as suas voltas e circunvoluçóes, os saltos mortais para a frente e para trás, não só são agradáveis para os que assistem, mas também salutares para os executantes. $\mathrm{Na}$ verdade, eu poderia afirmar que este é o mais belo e simultaneamente o mais harmonioso dos exercícios físicos, tornando o corpo mais maleável, mais flexível e mais ágil, treinando-o para se tornar mais dócil às mudanças de atitude e dando aos corpos um vigor nada desprezável.

72. Sim, como é que a dança não seria uma coisa altamente harmoniosa, ela que aguça a alma, exercita o corpo, deleita os espectadores e lhes ensina muitas coisas dos tempos antigos, ao som das flautas e dos címbalos, e com a cadência e o encanto de melodias dirigidas aos olhos e aos ouvidos?! Se procuras uma voz bem timbrada, em que outra parte poderias encontrá-la, ou que concerto mais forte e mais afinado? Mas se preferes o som mais estridente da flauta ou da siringe, a dança também tos pode proporcionar plenamente. Isto para já não referir como te tornarás moralmente melhor ao frequentares um tal espectáculo, quando vês o teatro em peso ${ }^{536}$ abominando as más acçôes e compadecendo-se das vítimas da injustiça, numa palavra, educando os costumes dos espectadores.

${ }^{535}$ Eth. Nicom., I, 8.

$536 \mathrm{O}$ texto grego diz, só, "o teatro», com o sentido de «espectadores».

O pequeno acrescento na tradução parece razoável. 
73. Mas aquilo que eu mais elogio nos dançarinos, vou dizê-lo desde já: o facto de eles exercitarem por igual a força e a delicadeza dos membros parece-me uma coisa extraordinária, como se numa mesma pessoa se evidenciassem a fortaleza de Héracles e a graciosidade de Afrodite.

74. Agora quero descrever-te, nesta minha obra, como deve ser um excelente dançarino, quer no aspecto moral, quer no físico, embora já anteriormente tenha falado das qualidades da alma: afirmo que ele deve ter boa memória, ser naturalmente bem dotado, inteligente, de compreensão rápida e, muito especialmente, captar os tempos certos. Além disso, deve saber julgar obras poéticas, ser capaz de distinguir os melhores cânticos e árias, e censurar aqueles que estão mal compostos.

75. No que respeita ao corpo, creio que este deve estar de acordo com o cânone $e^{537}$ de Policlito: nem excessivamente alto e comprido para além da média, nem muito baixo e quase anão, mas sim na medida exacta; nem muito gordo (o que seria pouco convincente), nem excessivamente magro (o que pareceria um esqueleto ou um cadáver).

76. A propósito, quero citar-te algumas piadas de uma certa assistência, que não era nada má a assinalar deficiências deste género. Os habitantes de Antioquia, cidade [de gente] espirituosa e particularmente apreciadora da dança, reparam com tanta atenção em tudo o que se diz e faz, que nada nem ninguém lhes escapa. Ora, como tivesse entrado em cena um dançarino de baixa estatura fazendo o papel de Heitor, todos os espectadores, a uma só voz, clamaram: "Ó $O^{538}$ Astíanax, onde está Heitor?» De outra vez, como um certo dançarino, de altura muitíssimo acima do normal, se preparasse para representar o papel de Canapeu e assaltar as muralhas de Tebas, exclamaram: "Pula por cima da muralha, não precisas nada de escada!" A outro dançarino, gordo e pesado, que se esforçava por executar enormes saltos, gritaram: "Por favor, poupa o palco!». Pelo

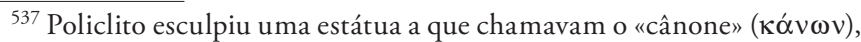
ou «modelo», que, pelas sua proporçôes harmoniosas, deveria servir de paradigma.

${ }^{538}$ Emenda moderna; outra emenda, também moderna: «Tu (és) A...». 
contrário, a outro, extremamente magro, gritaram: "Cuidado com a saúde!», como se ele estivesse doente.

Não te citei estes episódios a título de piada, mas antes para que vejas que todos os povos deram grande atenção à arte da dança, a ponto de serem capazes de julgar correctamente sobre as suas virtudes e os seus defeitos.

77. Depois disto, deve possuir extrema facilidade de movimentos e ter um corpo ao mesmo tempo flexível e rijo, que se dobre sempre que preciso, e resista firmemente quando necessário.

78. Por outro lado, que a dança não anda longe da prática gestual dos concursos públicos, mas antes também adopta os belos gestos nas lutas de Hermes, de Pólux e de Héracles, é o que poderás ver, observando cada uma destas imitaçóes.

Heródoto é de opinião que os factos apreendidos pelos olhos são mais fiéis do que pelos ouvidos; ora, a dança dirige-se tanto aos ouvidos como aos olhos.

79. É tal o poder de fascinação da dança, que, se um apaixonado entrar num teatro e vir [aí representadas] as nefastas consequências da paixão, fica logo sensato; e se estiver possuído de tristeza, sai do teatro mais alegre, como se tivesse ingerido alguma droga que faz esquecer, ou, como diz o poeta, "calmante da dor e da cólera ${ }^{539}$. Uma prova de que a dança se identifica com a realidade e de que cada um dos assistentes compreende o que está a ser interpretado, é o facto de, muitas vezes, os espectadores irromperem em lágrimas, quando lhes surge uma cena lastimável e digna de compaixão.

A dança báquica é particularmente apreciada na Jónia e no Ponto, e, embora de natureza satírica, tem subjugado de tal modo as pessoas dessas regióes, que, durante o tempo para ela fixado, esquecem-se de tudo o mais e ficam sentados dias inteiros a ver titãs, coribantes, sátiros e pastores. E quem executa tais danças são os mais nobres e mais importantes de cada uma das cidades, os quais de modo nenhum se envergonham, mas antes ficam altamente orgulhosos disso, ainda mais do que da sua nobreza, dos seus cargos públicos e das virtudes dos seus antepassados.

${ }^{539}$ Homero, Od., IV, 221. 
80. Depois de falar das virtudes dos dançarinos, escuta agora quais são os seus defeitos. Os do corpo, já eu os mencionei; quanto aos do espírito, tu mesmo serias igualmente capaz de os assinalar. De facto, muitos deles, por ignorância (pois é inconcebível que todos [os dançarinos] sejam instruídos), revelam, ao dançarem, graves incorrecçóes: uns executam movimentos sem sentido e que não concordam, como sói dizer-se, com o andamento musical, pois, enquanto o pé exprime uma coisa, o ritmo exprime outra; outros obedecem, de facto, ao ritmo, mas o seu movimento atrasa-se ou antecipa-se à acçáo, como me recordo de um dia ter visto. Foi o caso de um certo dançarino, que, ao querer interpretar o nascimento de Zeus e a cena de Crono a comer os filhos, dançou, erradamente, as desventuras de Tiestes, enganado pela semelhança do assunto ${ }^{540}$; outro, querendo interpretar Sémele atingida por um raio, confundiu-a com Glauce, que é mais recente. Em todo o caso, julgo que não devemos, com base em tais dançarinos, condenar a arte da dança em si mesma ou odiar essa actividade, mas sim considerar alguns deles ignorantes, que é o que eles são, e louvar os outros, aqueles que actuam sempre plenamente de acordo com as regras e o ritmo da arte.

81. Em termos gerais, o dançarino deve exercitar-se em todos os aspectos, de modo que, no conjunto, seja harmonioso, elegante, equilibrado, condicente com a personagem, irrepreensível, impecável, sem o mínimo defeito, composto do que há de melhor, de raciocínio vivo, de profunda cultura e, sobretudo, humano nos seus sentimentos. Assim, o mais completo elogio que lhe pode vir dos espectadores é quando cada um dos assistentes reconhece nele os seus próprios sentimentos, ou melhor, quando vê no dançarino, como ao ver-se num espelho, o que ele próprio costuma sentir e fazer. É nesse momento que as pessoas, já sem poderem conter-se, de prazer, irrompem em aplausos a uma só voz, ao verem, cada uma por si, as imagens da sua própria alma e nelas se reconhecendo a si próprios. Assim, com tal espectáculo, concretiza-se completamente nos espectadores a famosa máxima délfica, "Conhece-te a ti mesmo», e as pessoas saem do

540 Tal como Crono, também Tiestes comeu os seus filhos, mas em circunstâncias completamente diferentes, pois as crianças foram-lhe servidas à mesa por seu irmáo Atreu. As desventuras dos Atridas é das mais produtivas na tragédia antiga e, sem dúvida, também na dança. 
teatro conscientes do que devem preferir e do que devem evitar, e instruídas em coisas que antes desconheciam.

82. Tal como no discurso ${ }^{541}$, também com a dança se verifica aquilo a que se chama mau gosto, dito a respeito de muitos, que ultrapassam o justo limite da imitaçáo e exageram para lá do que é decente, e que, se se trata de mostrar uma personagem simplesmente grande, representam-na com uma grandeza descomunal, ou, se ela é apenas delicada, tornam-na exageradamente efeminada, ou levam a virilidade até às raias da selvajaria e da bestialidade.

83. Recordo-me de um caso destes, em que, uma vez, vi actuar um dançarino, antes muito apreciado e, aliás, inteligente e verdadeiramente digno de admiração, o qual, não sei lá por que motivo, se deixou arrastar para uma interpretaçáo disparatada, devido ao exagero da sua imitação. Foi o caso que, ao representar Ájax enlouquecido após a sua derrota, caiu num tal exagero, que as pessoas ficaram convictas de que não tinha representado a loucura, mas sim que ele próprio estava visivelmente louco. De facto, rasgou a veste a um dos que marcavam o ritmo com uma sandália ferra$\mathrm{da}^{542}$; a um dos flautistas arrancou a flauta e, brandindo-a de alto a baixo, rachou a cabeça ${ }^{543}$ de Ulisses, que estava ali ao lado todo orgulhoso da sua vitória; e se o forro do elmo não tivesse resistido e amortecesse a maior parte do golpe, o desgraçado do Ulisses teria morrido às mãos de um dançarino louco. Entretanto o teatro em peso tinha enlouquecido juntamente com o Ájax: os espectadores pulavam, gritavam e lançavam as vestes ao ar; uns, da arraia-miúda e leigos na matéria, que não percebiam o que era adequado e não distinguiam o pior do melhor e consideravam tal actuação como a perfeita imitação da paixão; outros, os mais polidos, que compreendiam e estavam envergonhados com o sucedido, não desaprovavam essa actuação com o seu silêncio, mas,

541 Pode entender-se "discurso falado ou escrito", "discurso literário», «literatura».

542 Trata-se da chamada kroúpeza, ou, em latim, scrupeda ou scabellum. A pessoa encarregada de marcar o ritmo por este processo era denominada scabellarius.

543 Entenda-se, não a cabeça propriamente dita, mas a máscara de todo o rosto e cabeça. 
pelo contrário, encobriam com os seus elogios a insensatez daquela dança, embora vendo claramente que aquilo que se representara era o resultado da loucura, náo de Ájax, mas do dançarino. De facto, não contente com este procedimento, o nosso homem fez outra coisa muito mais ridícula: desce para o meio do público e vai sentar-se na zona dos senadores, no meio de dois ex-cônsules ${ }^{54}$, os quais ficam completamente apavorados, não vá o homem voltar-se para um deles e flagelá-lo como a um carneiro. Entretanto, uns admiravam o feito, outros riam, e outros receavam que o homem tivesse passado de uma imitação exagerada para a demência real.

84. Aliás, diz-se que ele, uma vez recuperado o juízo, ficou tão arrependido do que tinha feito, que adoeceu de desgosto, reconhecendo-se culpado de autêntica loucura, o que ele mesmo demonstrou claramente. Foi o caso que, tendo-lhe os seus admiradores pedido que lhes dançasse novamente o papel de Ájax, declinou o pedido, dizendo aos espectadores: "Já basta que o actor tenha enlouquecido uma vez." Mas o que mais o desgostou foi o caso do seu antagonista e rival de profissáo: tendo sido escrito para este idêntico papel de Ájax, interpretou a [cena da] loucura de modo tão decente e táo moderado, que foi muito aplaudido, pelo facto de ter permanecido dentro dos limites da dança e náo ter loucamente adulterado a arte da interpretação.

85. O que acima te mencionei constitui apenas, querido amigo, uma pequena parte das muitíssimas matérias e ocupaçôes inerentes à dança, para que não te irrites demasiadamente comigo pelo facto de eu assistir apaixonadamente a tais representaçôes. Mas se tu porventura te dispusesses a compartilhar comigo desse espectáculo, tenho a certeza de que ficarias plenamente conquistado e, daí em diante, serias um maníaco da dança. Nesse caso, não terei necessidade de te recitar aquele verso de Circe, que diz:

Tomada sou de espanto, que não fiques, ||bebendo esta poção, [enfeitiçado ${ }^{545}$,

${ }^{544}$ Vê-se que Luciano se refere a um ambiente romano.

545 Odisseia, X, 326. A feiticeira Circe dirige-se a Ulisses, a quem dera a beber uma poção mágica que o transformaria em porco (como já fizera 
pois, na verdade, ficarás enfeitiçado, mas, por Zeus!, não ganharás uma cabeça de burro ou um coração de porco ${ }^{546}$; pelo contrário, o teu espírito ficará mais forte, e tu, inebriado de prazer, não darás a beber a outro nem sequer uma pequena gota da beberagem. De facto, aquilo que Homero diz a respeito da vara de oiro de Hermes, com a qual

$$
\begin{array}{r}
\ldots .|| \text { os olhos de alguns homens enfeitiça }{ }^{547} \text {, } \\
\text { enquanto a outros, a seu bel-prazer, ||estando adormecidos, os } \\
\text { [desperta }{ }^{548},
\end{array}
$$

é exactamente o que a dança provoca, quer enfeitiçando os olhos, quer mantendo a mente acordada e bem desperta para todos os pormenores da acção.

CRÁTON - Agora sim, Licino, já me deixo convencer por ti e fico com os ouvidos e os olhos bem abertos. Mais: quando fores ao teatro, lembra-te, querido amigo, de reservar também um lugar para mim, ao teu lado, para que não sejas só tu a regressar de lá mais instruído.

aos seus companheiros). Hermes, porém, dera ao herói um antídoto eficaz, que ele usou.

546 Entenda-se: como os companheiros de Ulisses, enfeitiçados por Circe e transformados em porcos.

${ }^{547}$ Aqui, diferentemente da citação anterior, «enfeitiçar» vai no sentido de «embalar», «adormecer», por oposição a «despertar» do verso seguinte. ${ }^{548}$ Odisseia, V, 47-48. 
HERMOTIMO OU AS ESCOLAS FILOSÓFICAS 



\section{HERMOTIMO OU AS ESCOLAS FILOSÓFICAS}

\section{INTRODUÇẤO}

Uma dúzia de anos depois de ter saído da sua terra natal, Luciano regressa a casa, mas por pouco tempo. Decide fixar-se com a família em Atenas, onde permanece por cerca de vinte anos (c. 165-185 d. C.). A Dupla Acusação deve datar dos primeiros anos da sua esta na capital da cultura. Amadurecido pelas viagens e pela experiência da vida, materialmente afortunado, este homem de cerca de quarenta anos (v. $\$ 32)$ cedo se farta da actividade judiciária, da retórica e da sofística, para se entregar a uma actividade literária que, não sendo nova, ele, no entanto, reforma de maneira radical: trata-se do diálogo filosófico, mas agora entendido e elaborado segundo princípios originais. De facto, Luciano aligeira substancialmente o majestoso diálogo filosófico que vinha dos tempos de Platáo, e acrescenta-lhe um aspecto dramático, orientado no sentido da sátira - o que significa reunir no "novo género» dois géneros diferentes e até muito diversos: o diálogo filosófico e a comédia. E realmente foram sobretudo as obras em forma de diálogo que deram fama a Luciano. É nelas que melhor se expande a sua crítica panfletária e corrosiva, que atinge - literalmente - tudo e todos: os deuses e os heróis, a religiáo e as religiôes, a filosofia e as suas variadíssimas seitas, a moral convencional, a sociedade e os seus pilares mais destacados, os homens e as suas vaidades, as sua superstiçóes irracionais e o aproveitamento que delas fazem os espertos... enfim, podemos dizer que em Luciano conflui o que de mais violento havia na comédia. Um certo epicurismo prático e um cinismo teórico afinam e refinam o processo.

Para termos uma ideia da contribuição de Luciano para este novo estilo de diálogo filosófico, nada melhor do que invocar o próprio autor.

Na Dupla Acusação (ou Os Julgamentos), a que acima se fez referência, Luciano póe em cena um processo judiciário de extraordinária movimentação dramática, com mais de uma dúzia de intervenientes. Para o assunto que nos interessa, basta dizer que, a certa altura, o deus Hermes, feito «oficial de diligências", introduz as personagens dum curioso processo, em que a Retórica e o Diálogo se apresentam, personificados, como acusadores dum tal Sírio (o próprio Luciano). 
A Retórica, «esposa legítima» de Luciano e sua benfeitora, apresenta ao tribunal uma sentida queixa por abandono do lar e amantização do esposo com "este barbudo, o Diálogo»... "E é que não sai dos braços deste amante mais velho que ele...".

A defesa do acusado consiste em mostrar que a Retórica havia perdido o seu antigo recato, já não conservava aquela postura nobre e decente dos tempos antigos, mas antes se ataviava da maneira mais provocante, se penteava como as meretrizes, cobria o rosto de cosméticos... indícios claros (aliás: desconfianças certas) duma conduta reprovável. Por isso, o réu decidira procurar outra companhia, precisamente o Diálogo, que agora, também ele, se apresenta como acusador. Diz entáo o Diálogo:

"Até aqui, eu era cheio de gravidade, sempre em contemplação perante os deuses, a natureza e as revoluçôes do Universo: caminhava nos ares por regióes vizinhas das nuvens......, rasava a abóbada celeste e lançava-me até mesmo acima do céu...... Até que este Sírio, puxando-me por uma perna e quebrando-me as asas, me reduziu à condição comum. Arrancou-me a máscara trágica e majestosa e colocou-me outra, cómica, satírica e quase ridicula. Num ápice, reuniu e encerrou em mim a jocosidade mordaz, o jambo ${ }^{549}$, o cinismo, Êpolis e Aristófanes ${ }^{550}$ - homens hábeis na arte de troçar daquilo que toda a gente respeita...... Enfim, foi desenterrar um tal Menipo ${ }^{551}$, um cínico dos tempos idos, um cão ladrador, armado de dentes afiados...... um autêntico cão, animal terrivel, que morde sem se dar por isso, e tanto mais que morde a rir......"

\section{Claro que o Sírio-Luciano não tem dificuldade em se de- fender:}

"Senhores juizes: Eu não contava com ter de sustentar, diante de vós, um tal debate; esperava, sim, ouvir o Diálogo dizer a meu respeito palavras completamente diferentes."

${ }^{549}$ A poesia jâmbica (ou iâmbica), de que Arquíloco é o mais famoso cultor, salienta-se pela violência dos ataques pessoais.

${ }^{550}$ Eupolis atque Cratinus Aristophanesque poetae..., no dizer de Horácio e no sentimento geral de toda a Antiguidade, eram os mais célebres poetas da chamada "comédia antiga». De Aristófanes chegaram até nós onze das quarenta comédias que escreveu, enquanto dos restantes (em número de várias centenas) apenas subsistem fragmentos, geralmente transmitidos por citaçóes de autores antigos que ainda puderam ler essas obras.

551 Menipo é uma figura frequente nos diálogos de Luciano e seu "porta-voz» preferencial. 
E Luciano recorda os tempos em que primeiro encontrara o Diálogo, maçudo, com uma fisionomia sem dúvida venerável, mas pouco graciosa e absolutamente desagradável para o público. "Então eu comecei a ensiná-lo a andar com os pés na terra, à maneira dos homens... forcei-o a sorrir, tornei-o mais agradável aos espectadores; mas, sobretudo, associei-o à Comédia e, com esta aliança, fi-lo ganhar a benevolência dos ouvintes, os quais, até então, se receavam dos espinhos de que ele estava armado e não ousavam tocar-lhe, como se fosse um ouriço.» Numa palavra, desviou-o de questôes ridiculamente subtis, "se a alma é imortal", etc. "De facto, ele gosta de discutir essas miudezas, como as pessoas que têm sarna gostam de se coçar..." Apesar de tudo, porém - elemento importantíssimo para a defesa -, deixou-lhe as vestes gregas, ou seja, a pureza de linguagem, o encanto do dialecto ático, "e isto apesar de eu próprio ser um bárbaro» - diz o Sírio (Luciano, já se vê).

A longa estada de Luciano em Atenas marca o período mais fecundo da sua actividade. Estava-se, então, na plena força daquilo a que se convencionou chamar a «Segunda Sofística», que mais não é que um renascimento da cultura «clássica». Para além de todas as virtudes e de todos os defeitos deste renascimento, nós, homens modernos, devemos-lhes um serviço que geralmente passa despercebido: estes homens, possuidores duma cultura enciclopédica que tinha atrás de si meio milénio (e até mais) de produção escrita, ganharam o gosto de possuir as suas próprias bibliotecas - donde se originou uma florescente actividade editorial, que não só multiplicou as obras mais famosas dos períodos anteriores, como, sobretudo, salvou muitas outras, as quais, preservadas em pequeno número de exemplares, estavam em risco iminente de se perderem para sempre. Foram, em parte, estas cópias que chegaram às máos dos bizantinos, e daí à cultura ocidental.

Ora, Luciano possuía também os seus livros, mas, tal como hoje acontece com muito boa gente, não tinha possibilidade de satisfazer todos os seus desejos neste particular. Mas havia os bibliómanos, sempre ricos e geralmente ignorantes, contra os quais Luciano chegou a escrever um panfleto, Contra um Bibliómano Ignorante $e^{552}$. Trata-se dum indivíduo que se julga

552 Existe uma edição "de autor», Lisboa. 1997, em poucos exemplares... à consideração de algum editor... 
culto, ou pretende sê-lo, pelo facto de comprar os mais belos livros, isto é, edições de luxo. Pior que isso, o homem guia-se pela publicidade feita à volta de obras medíocres, tornando-se, assim, um maná (ou "presente de Hermes»"53) para os livreiros. Falta-lhe, porém, o sentido crítico, e a cultura não entra por osmose. Luciano compara-o, sucessivamente, a um cego, a um macaco e a um burro. Em todo o caso - conclui - o cretino faria obra piedosa, se, ao menos, emprestasse os seus livros a outros. Mas não: "Tu nunca emprestaste um livro fosse a quem fosse: és como o cão, que, deitado na estrebaria, e não comendo cevada, náo deixa o cavalo comer..."

Ora, foi este ambiente de falsa erudição, que alastrava a olhos vistos, que Luciano veio encontrar em Atenas. O Hermotimo deve reflectir uma das primeiras experiências de Luciano neste aspecto. Com o tempo, a pessoa farta-se.

Aos quarenta e poucos anos, Luciano adopta uma atitude fundamentalmente céptica, que, sobretudo, se insurge contra todo o dogmatismo metafísico e filosófico. Tal é, justamente, o tema do Hermotimo. Este diálogo é, dentre todos, o mais extenso e o mais "expositivo», e, consequentemente, o menos dramático e porventura o menos ostensivamente satírico. Para sermos exactos, outros diálogos se conformam mais estreitamente aos processos técnico-estilísticos acima expressos. Assim, a Dupla Acusação distingue-se pela extraordinária vivacidade dramática, acentuada pela participação de grande número de personagens, cujas intervençóes, ora curtas, ora mais extensas, pontuam e dirigem a acção de conjunto; outros, como os Diálogos dos Mortos, oferecem-nos grupos de pequenos quadros completamente independentes uns dos outros, com um número maior ou menor de personagens, mas sempre de reduzida extensão são como "quadros de revista", nos quais o elemento dramático está concentrado ao máximo; noutros ainda, como é o caso do Hermotimo, o número de intervenientes fica reduzido à expressão mais simples de dois interlocutores, pelo que, naturalmente, o aspecto dramático se esbate, em favor da técnica expositiva, que leva as personagens a fazer intervençôes por vezes muito longas.

${ }^{553}$ Hermes, além de deus psicopompo ("condutor de almas»... para os Infernos), de músico e construtor da lira, era (já desde bebé!) um ladrão exímio e patrono das actividades comerciais (o equivalente do Mercúrio romano). 
Numa palavra, o Hermotimo aproxima-se do diálogo platónico, tanto quanto se afasta do modelo da Dupla Acusação ou dos Diálogos dos Mortos. Estou inclinado a pensar que o autor (Luciano, ou Licino, na obra), por um lado, "consente» em se conformar à técnica de argumentação do seu adversário, e, por outro, teria entendido que o assunto era táo sério, que se impunha uma certa contenção, isenta dos processos mais cruamente burlescos, mas, mesmo assim, sorridente e irónica: rude, mesmo rude, só o golpe final.

Justamente esta seriedade fundamental faz do Hermotimo uma obra-prima do cepticismo antigo, uma obra dum niilismo verdadeiramente perturbador, que não pode deixar indiferente $o$ homem moderno, também ele vacilante, inseguro e vagabundo, entre as certezas totais e o pessimismo iconoclasta. Se Luciano pertence a este último grupo, não terá lá as suas razôes?

Enfim, uma última sugestão: tenha o leitor a paciência de ler com todo o seu vagar uma obra que, explicitamente, não tem pressas - uma das personagens (Licino... Luciano) diz à outra (Hermotimo) que dispóem do dia inteiro para discutir...

Ao longo de todo este vagaroso percurso, adivinha-se um desenlace verdadeiramente trágico, cujo momento o autor se compraz em retardar o mais possível. De argumento em argumento, de comparaçáo em comparaçáo, caminhamos inexoravelmente no sentido das certezas iniciais para as dúvidas, e daqui para a conclusão final, expressa pelo próprio recém-convertido ao cepticismo, Hermotimo, com uma força dramática que vai até às lágrimas (cf. $\$ 84$ ), prossegue com sentimentos de náusea ( $\$$ 86: «Oxalá eu pudesse vomitar todas essas tretas que lhes ouvi!») e termina com uma repulsa lúcida e firme, no exacto termo do diálogo: «De hoje em diante, se alguma vez, e contra a minha vontade, ao caminhar na rua, topar com um filósofo, desviar-me-ei dele, evitá-lo-ei como a um cão danado.» 
(Página deixada propositadamente em branco) 


\section{HERMOTIMO OU AS ESCOLAS FILOSÓFICAS}

1. LICINO - A julgar pelo livro e por essa passada rápida, parece, Hermotimo, que tens pressa de chegar a casa do teu mestre. Certamente que, mesmo caminhando, ias a reflectir nalgum assunto, pois mexias os lábios, murmurando baixinho, e gesticulavas com a mão, para a direita, para a esquerda... Dir-se-ia que compunhas mentalmente um discurso, ou elaboravas algum desses problemas retorcidos, ou magicavas numa questáo sofística, de forma que nem mesmo caminhando na rua te permites descansar: pelo contrário, estás sempre em actividade, ocupado com alguma questão importante, de interesse para os teus estudos.

Hermotimo - Sim. Licino, por Zeus!, é mais ou menos isso: estava a passar em revista a lição de ontem, percorrendo de memória cada um dos pontos que o mestre nos expôs. É que não devemos desperdiçar um momento sequer, conscientes como estamos da verdade expressa pelo médico de Cós ${ }^{554}$, a saber: "A vida é breve, a arte longa». E, no entanto, ele referia-se à medicina, que é matéria mais fácil de aprender, ao passo que a filosofia, mesmo a longo prazo, é inatingível, a não ser que uma pessoa, de espírito bem desperto, se ocupe dela com tenacidade contínua e olhar atento; além do mais, a empresa envolve um risco grave: ou ser infeliz, perdido na enorme multidão de gente comum, ou encontrar a felicidade na filosofia.

2. LICINO - Realmente, Hermotimo, o prémio é tão maravilhoso quanto acabas de dizer; e cuido mesmo que tu náo te encontras longe de obtê-lo... pelo menos a avaliar pelo tempo que já levas no estudo da filosofia, bem como pelo zelo incomum que, a meu ver, desde há muito demonstras possuir. Sim: se bem me lembro, de há quase vinte anos a esta parte que não te vejo fazer outra coisa senão frequentar os mestres, ou completamente enfronhado na leitura, ou tomando notas das liçóes, sempre pálido e escanzelado devido ao esforço intelectual. Estás a tal ponto metido nessa actividade, que tenho a impressáo de que nem a sonhar dás descanso a ti próprio. Ora, considerando tudo isso, afigura-se-me que, em prazo não muito dilatado, vais alcançar a felicidade, se é que realmente não a atingiste já há muito, mas nos escondes o facto.

${ }^{554} \mathrm{O}$ célebre Hipócrates. 
Hermotimo - Como é isso, Licino, se só agora começo a vislumbrar o caminho? Ora a Virtude, no dizer de Hesíodo, mora muito longe, e o caminho que a ela conduz é longo, ladeirento e escabroso, exigindo do caminhante uma dose nada pequena de suor.

LICINO - Mas então, Hermotimo, não suaste e não caminhaste já o suficiente?

HERMOTIMO - Não, garanto-te. Efectivamente, se me encontrasse lá no cume, nada obstaria a que fosse completamente feliz. Ora, neste momento, Licino, ainda só estou no começo.

3. LICINO - Mas o começo - di-lo o mesmo Hesíodo - é meio caminho andado, de modo que não erraremos, se dissermos que te encontras já a meio da subida.

HERMOTIMO - Isso ainda não, pois já significaria ter conseguido muitíssimo.

LICINO - Mas então em que ponto da viagem diremos que te encontras?

HERMOTIMO - Ainda cá em baixo, Licino, nas faldas, pois só desde há pouco me esforço por avançar. Para mais, o caminho é escorregadio e escarpado, é preciso que alguém nos estenda a mão.

LICINO - Justamente o teu mestre é que pode prestar-te tal serviço: à semelhança do Zeus homérico, que fez baixar uma corda de oiro, também ele, por ter há muito efectuado a subida, te lançaria lá do alto da montanha os seus próprios ensinamentos, com os quais te puxaria, isto é, te içaria até junto dele e da Virtude.

Hermotimo - O que disseste, Licino, é precisamente o que se passa. E, de facto, se dependesse só dele, há muito que já estaria içado e na sua companhia. A deficiência é minha.

4. LICINO - Mas há que ter coragem e ânimo forte, e pôr os olhos no termo do caminho e na felicidade lá do alto, tanto mais que o mestre também se esforça. Porém... que esperança te dá ele de que irás conseguir - e quando? Calcula ele que estarás no cume lá para o ano que vem... digamos, depois dos Mistérios a seguir a estes, ou depois das Panateneias?

HERMOTIMO - Ó Licino, estás a dar um prazo curto.

LICINO - Então e lá para a próxima Olimpíada?...

HERMOTIMO - Mas isso ainda é pouco para me exercitar na virtude e possuir a felicidade. 
LICINO - De qualquer forma... daqui a duas Olimpíadas?... Senão, poderiam acusar-te de grande indolência, caso náo o conseguisses num período como este, que dá para ir e vir facilmente três vezes das Colunas de Hércules ${ }^{555}$ até à Índia, mesmo sem andar em linha recta e sem caminhar continuamente, mas incluindo desvios para visitar os povos que ficam pelo meio. Em todo o caso, quanto é que achas, mais ou menos, que esse pico, onde habita a nossa Virtude, é mais alto e escorregadio que o de Aorno, que Alexandre ${ }^{556}$ tomou pela força em poucos dias?

5. Hermotimo - Isso não tem comparação, Licino: a empresa não é como tu a imaginas, não é coisa susceptível de se levar a cabo e ser conquistada em pouco tempo... nem que milhares de Alexandres a atacassem. Se assim fosse, muita gente haveria que a escalasse. $\mathrm{O}$ que acontece, porém, é que não são poucos os que começam com força extraordinária e vão avançando alguma coisa, uns bastante pouco, outros mais. Contudo, ao chegarem a meio da viagem, e perante as enormes dificuldades e contratempos, perdem a coragem e voltam para trás, sem fôlego e escorrendo em suor, enfim, sem suportarem o cansaço. Mas os que aguentarem até ao fim, esses, atingem o cume e, a partir de então, alcançam a felicidade e passam a gozar, para sempre, duma vida maravilhosa, contemplando, lá do alto, os outros homens - quais formigas.

LICINO - Eh lá, Hermotimo! Como nos fazes tão pequenos...: nem sequer do tamanho desses tais Pigmeus, mas sim seres rastejantes pela superfície da terra... o que é natural, aliás, porquanto o teu espírito já só concebe ideias sublimes, elevadas. Quanto a nós, arraia-miúda, nós que andamos cá por baixo, passaremos a dirigir-vos preces como a deuses entre deuses, a vós que estais acima das nuvens e subistes às alturas a que longamente aspiráveis.

Hermotimo - Ó Licino, quem me dera já lá estar em cima! Mas o que falta [percorrer] é tanto...

6. LICINO - Contudo, ainda não disseste quanto [é que falta], de forma que eu possa calcular o tempo [necessário].

555 Nome antigo do estreito de Gibraltar.

556 Trata-se de Alexandre, filho de Filipe da Macedónia, que construiu um vasto império, que incluía a Grécia, a Ásia Menor e parte da Índia. 
Hermotimo - Nem eu próprio o sei ao certo, Licino. Suponho, porém, que será coisa para não mais de vinte anos; passado esse tempo, certamente que me encontrarei lá no cume.

LICINO - Por Héracles, tanto tempo?!

HeRMOTIMO - É que os meus esforços, Licino, têm por objectivo um grande prémio.

LICINO - Talvez seja verdade. Mas... será que o teu mestre, não apenas sábio, mas também adivinho, te prometeu que viverias para além desses vinte anos - ele ou algum oráculo ou um dos muitos especialistas das ciências caldaicas? Pelo menos afirma-se que eles percebem dessas coisas. É que, realmente, não se me afigura razoável que tu, na incerteza de viveres até alcançar a Virtude, suportes tamanhas atribulaçóes e sofras noite e dia, sem saber se, já muito próximo do cume, não chega o Destino, que te pega por uma perna e te despenha do alto da esperança irrealizada.

HERMOTIMO - Para longe tal ideia! Realmente, Licino, é de mau agoiro. Em todo o caso, quem me dera viver o suficiente para chegar a sábio e alcançar a felicidade, nem que seja por um só dia!

LICINO - Mas bastar-te-á um só dia em paga de tantos trabalhos?

HeRMOTIMO - Para mim, um só instante é quanto basta.

7. LICINO - Mas como podes tu saber que essa coisa lá de cima é de facto a felicidade, e que ela é tal, que vale a pena suportar tudo para alcançá-la? Sim, que tu, pessoalmente, nunca estiveste lá em cima.

HERMOTIMO - Mas acredito no que diz o meu mestre, que o sabe muito bem, como pessoa que já vive nessas alturas.

LICINO - Então, pelos deuses!, que é que ele diz das condiçôes de vida e da felicidade que lá reinam? Fala, por exemplo, de riqueza, glória, prazeres incomparáveis...?

HERMOTIMO - Mais respeito, companheiro: essas coisas não têm nada que ver com a vida virtuosa.

LICINO - Mas então que bens, sem serem esses, afirma ele que alcançarão os que chegarem ao fim da ascese?557

HERMOTIMO - Sabedoria, coragem, beleza autêntica, justiça e o convencimento de conhecer todas as coisas de ciência certa, cada uma tal como é na realidade. Quanto a coisas como

557 Recorde-se que ascese ( $\alpha$ $\sigma \kappa \eta \sigma \imath \varsigma)$ não tem que ver com «subida", mas com «exercício (espiritual)» $(\dot{\alpha} \sigma \kappa \varepsilon \dot{\varepsilon} \omega)$. 
riquezas, glórias, prazeres e demais bens físicos, tudo isso ele deixou cá em baixo, de tudo se despojou para efectuar a ascensão - tal qual se conta a respeito de Héracles, o qual, após ter sido queimado no monte Eta ${ }^{558}$, foi divinizado; de facto, perdido o que de humano herdara de sua mãe, ficou apenas com a parte divina, limpa, sem mistura e depurada pelo fogo. Só então pôde voar para junto dos deuses. Ora, também estes homens, que a filosofia, como um fogo, despojou de tudo aquilo que, por deficiência de apreciação, os outros consideram estimáveis, também eles, uma vez atingido o cume, alcançam a felicidade e já nem se lembram da riqueza, da glória e dos prazeres: pelo contrário, desdenham dos que cuidam que esses bens são reais.

8. LICINO - Por Héracles... no Eta! Tu, Hermotimo, referes-te a esses homens em termos como coragem, felicidade... No entanto... diz-me cá uma coisa: será que eles, caso queiram, descem uma vez por outra lá das alturas e mantêm relaçôes com os que deixaram cá em baixo? Ou, pelo contrário, uma vez chegados lá acima, têm forçosamente de lá permanecer, em convivência com a Virtude e desdenhando das riquezas, da glória e dos prazeres?

Hermotimo - Isso e não só, Licino: todo aquele que conseguiu aperfeiçoar-se na virtude não mais será escravo nem da cólera, nem do medo, nem da paixão; não mais sentirá a tristeza... numa palavra, náo será afectado por qualquer sentimento deste género.

LICINO - Mesmo assim... (se é que posso, sem receio, falar francamente...) - Mas... creio... devo calar-me respeitosamente, pois não seria piedoso examinar os actos desses sábios...

HERMOTIMO - De modo nenhum! Vamos, diz o que tens a dizer!

LICINO - Repara, companheiro, como estou receoso...

HeRMOTIMO - Ora, ora, meu bravo amigo, não tenhas receio, que mais ninguém nos ouve.

9. LICINO - Dum modo geral, Hermotimo, fui seguindo a tua exposiçáo, e estava em crer que era mesmo assim: que esses homens se tornavam sábios, corajosos, justos, etc. Estava mesmo a ficar seduzido pelas tuas palavras. Quando, porém,

${ }^{558}$ Héracles (ou Hércules) foi um dos muitos filhos bastardos de Zeus, fruto do seu amor furtivo com a mortal Alcmena, esposa de Anfitriāo. O tema é bem conhecido: v. A. José da Silva, Anfitrião, "Clássicos Inquérito", no 14. 
afirmaste que eles desprezavam riqueza, glória e prazeres, e que nunca se encolerizam nem se entristecem, aí,,, (estamos só os dois, não é?)... aí sim, parei, ao vir-me ao espírito o que outro dia vi fazer a... a... Queres que diga quem era, ou já basta mesmo sem o nomear?

HERMOTIMO - De modo nenhum: diz lá de quem se trata.

LICINO - Pois é o teu próprio mestre - homem, aliás, mui digno de respeito, tanto mais que já é extremamente velho.

HERMOTIMO - E que é que ele fez?

LICINO - Conheces aquele forasteiro de Heracleia, um seu discípulo, que há muito estudava filosofia com ele... um sujeito loiro, quezilento?

HERMOTIMO - Sei a quem te referes: chama-se Díon.

LICINO - Esse mesmo. Ora, como ele, segundo creio, não pagava ${ }^{559}$ pontualmente a mensalidade, outro dia o mestre passou-lhe o manto à volta do pescoço $\mathrm{O}^{560} \mathrm{e}$, em grande algazarra e irritação, arrastou-o à presença do arconte; e se alguns dos seus colegas náo se tivessem metido de permeio e náo lhe tivessem tirado o jovem das máos, podes ficar certo de que o velho, de furioso que estava, se teria atirado a ele e lhe arrancaria o nariz à dentada.

10. Hermotimo - De facto, Licino, esse tal sempre foi um tipo reles e um caloteiro de marca; e a prova é que, pelo menos aos outros (e muitos são aqueles a quem o mestre empresta dinheiro), nunca os tratou dessa maneira, pois pagam os juros dentro do prazo ${ }^{561}$.

LICINO - Mas, meu caro, que lhe importa a ele que náo paguem, uma vez que já está purificado pela filosofia e, por conseguinte, já não tem necessidade do que deixou cá neste... «Eta»?562

HERMOTIMO - Julgas que é por motivos pessoais que ele se ocupa de tais coisas? Náo... É que ele tem filhos menores, de quem tem de cuidar, a fim de náo virem a passar necessidades.

${ }^{559} \mathrm{O}$ imperfeito, em grego como em português, indica uma acção contínua, habitual; e de facto, adiante Hermotimo diz que o sujeito era um «caloteiro de marca».

560 Trata-se dum gesto jurídico-ritual, para indicar a todos que o sujeito estava "filado».

561 Como se vê, o venerável mestre de Hermotimo era um terrível agiota, e Licino náo deixa de explorar este aspecto.

562 Nós diríamos: «neste Vale de Lágrimas». 
LICINO - Torna-se necessário, Hermotimo, levá-los, também a eles, lá para cima, para junto da Virtude, a fim de serem felizes na companhia do pai e desprezarem a riqueza.

11. HERMOTIMO - Bem, Licino, não tenho vagar de discutir contigo este assunto, pois estou com pressa de assistir à aula do mestre; se me descuido, fico irremediavelmente atrasado.

LICINO - Anima-te, meu caro, que hoje foi proclamado feriado, pelo que eu mesmo te dedico o resto da jornada.

HERMOTIMO - Como dizes?...

LICINO - Que de momento não poderás vê-lo... pelo menos a crer no aviso. Sim, estava uma tabuleta pendurada na porta, que dizia em grandes letras: HOJE NÃO HÁ AULA DE FILOSOFIA. Aliás, dizia-se que, tendo ele sido convidado para jantar ontem em casa do célebre Êucrates, que festejava os anos da filha, no decorrer do banquete ${ }^{563}$ dissertou abundantemente sobre filosofia, abespinhou-se um tanto ou quanto com o peripatético Eutidemo e discutiu com ele os argumentos que esses filósofos costumam opor aos da banda do Pórtico ${ }^{564}$. Durante a festa, que, segundo dizem, se estendeu até para lá da meia-noite, a gritaria provocou-lhe uma forte indisposição de cabeça, e fartou-se de suar. A juntar a tudo isso, quando chegou a altura de os convidados, segundo o costume, brindarem à amizade, já ele estava bem bebido, mais, creio eu, que o razoável; e também tinha comido mais do que convém a um velho, a tal ponto que, como me afirmaram, regressado a casa, fartou-se de vomitar; e mal acabou de contar e marcar cuidadosamente com o seu sinal todos os pedaços de carne que havia passado ao rapaz que estava atrás dele ${ }^{565}$, foi-se deitar, dando ordem de, daí em diante, não deixarem entrar ninguém. Isto foi o que eu ouvi dizer ao seu criado Midas, que

563 Trata-se, mais exactamente, da segunda parte do banquete, o beberete, em que se elegia um assunto de discussão...

${ }^{564}$ Filosofia do Pórtico ou estoicismo. Luciano, embora, aqui e noutras obras, declare guerra a (quase...) todas as escolas filosóficas (ou aos respectivos "filósofos»), ataca de preferência a filosofia idealista dos estóicos; muito mais poupados são os epicuristas e os cínicos, cuja visão pragmática e ultra-racional mais se conformava com as ideias do autor.

${ }^{565}$ Mais uma prova da mesquinhez do grande mestre: durante o banquete, passava disfarçadamente pedaços de carne ao criado que o acompanhava; depois, chegado a casa, contava e marcava os pedaços, para que ninguém lhe comesse alguma peça... 
contava o caso a alguns discípulos, os quais também tiveram de voltar em massa para trás.

12. Hermotimo - Mas quem é que ganhou, ó Licino: o meu mestre ou Eutidemo? Midas disse alguma coisa a esse respeito?

LICINO - Ao princípio, Hermotimo, consta que estavam mais ou menos empatados, mas no final a vitória pendeu para o vosso lado: o velho foi claramente superior. Dizem até que Eutidemo não se foi dali incólume, mas ficou com uma enorme brecha na cabeça. Realmente, como o fulano se mostrava fanfarrão e implicativo, e não queria deixar-se convencer nem aceitava às boas que o contradissessem, o valentão do teu mestre, que tinha na mão uma taça como a de $\mathrm{Nestor}^{566}$, prega com ela em cima do outro (que estava ali à máo de semear)... e pronto: ganhou.

HERMOTIMO - E foi muito bem feito, De facto, não devemos tratar doutro modo quem náo quer ceder aos mais fortes ${ }^{567}$.

LICINO - Excelente argumento esse, Hermotimo. Sim, que é que deu na cabeça de Eutidemo, para irritar um velho pachorrento, senhor dos seus sentimentos, e que, para mais, tinha na mão uma taça táo pesada?

13. Mas, mudando de assunto: já que temos vagar, porque é que não contas a este teu companheiro como é que começaste a sentir-te atraído para a filosofia, a fim de que também eu, se ainda é possível, a partir desse ponto, vos acompanhe na viagem? É claro que não ides excluir-me, como amigos que somos...

HERMOTIMO - Assim tu o queiras, Licino. Não tardarás a verificar quão diferente ficarás dos outros homens: em comparação contigo (podes ter a certeza), considerá-los-ás a todos umas crianças, a tal ponto os ultrapassarás intelectualmente.

LICINO - Já me contentaria, se ao fim de vinte anos pudesse tornar-me no que tu és neste momento.

HERMOTIMO - Não te dê cuidado: também eu comecei a estudar filosofia mais ou menos na tua idade - perto dos quarenta anos, que é, creio eu, a tua idade actual.

${ }^{566}$ Nestor, rei de Pilos, o mais velho e venerando herói da guerra de Tróia, naturalmente bebia por uma taça adequada à sua estatura e à sua qualidade.

${ }^{567}$ A observaçáo de Hermotimo revela-o como incondicional admirador e defensor do seu mestre. Na fala seguinte, Licino corrobora o raciocínio, com uma ironia que mal disfarça o seu verdadeiro sentido. 
LICINO - Exactamente, Hermotimo. Portanto, admite-me também a mim e conduz-me pelo mesmo caminho. Sim, é de justiça... Mas, antes de mais, diz-me cá uma coisa: será que vós permitis aos vossos discípulos que vos façam objecçôes, caso entendam que determinado assunto não está a ser correctamente tratado, ou, pelo contrário, náo consentis tal coisa aos noviços?

HERMOTIMO - Nem por sombras. Tu, porém, sempre que quiseres, faz as tuas perguntas e objecçóes, enquanto caminhamos. Dessa forma, até poderás aprender com mais facilidade.

LICINO - Muito bem, Hermotimo..., por Hermes!, esse deus de quem és epónimo ${ }^{568}$.

14. Porém, diz-me cá: por acaso o caminho dos vossos estóicos é o único que conduz à filosofia, ou é verdade, como tenho ouvido dizer, que há para aí muitos outros [filósofos]?

HERMOTIMO - Muitíssimos: os peripatéticos, os epicuristas, os que se reclamam de Platáo, e outros mais, sequazes de Diógenes e de Antístenes..., os pitagóricos, e muitos outros.

LICINO - Lá isso é verdade: são bastantes. Mas... ó Hermotimo, dizem todos eles a mesma coisa, ou coisas diferentes?

HERMOTIMO - Muitíssimo diferentes.

LICINO - De qualquer maneira, julgo eu, só uma dessas doutrinas contém a verdade, e não todas elas, visto que são diferentes.

HERMOTIMO - Precisamente.

15. LICINO - Ora bem, meu querido amigo, responde-me cá: quando, logo de início, estavas prestes a dedicar-te à filosofia, e em vista das muitas portas que te estavam abertas, em que é que te baseaste para pores de lado todas as outras e entrares pela dos estóicos, convencido de que por essa (a única verdadeira e que indicava o recto caminho) é que acederias à Virtude, ao passo que as outras conduziam a um final sem saída? Em que critério fundamentaste a tua escolha? Mas atenção: não penses em ti em termos actuais, como homem meio sábio ou mesmo sábio que agora és, capaz de melhor julgamento que a maior parte de nós; pelo contrário, responde-me exactamente como eras nesse tempo: um homem comum, como eu sou neste momento.

HERMOTIMO - Ó Licino, não alcanço o que pretendes dizer com isso.

568 Hermotimo significa «honrado por Hermes». 
LICINO - E no entanto, eu não levantei nenhuma questão muito complicada. De facto, havendo tantos filósofos, como Platáo, Aristóteles, Antístenes, os teus predecessores Crisipo e Zenão ${ }^{599}$, e tantos outros, em que é que te baseaste para rejeitar as demais [doutrinas]? Porque é que, dentre todas as escolas, optaste de preferência por essa e resolveste estudar filosofia segundo os seus princípios? Acaso Apolo Pítio, como aconteceu com Querefonte ${ }^{570}$, te mandou para os estóicos, dizendo-te que eles eram os melhores de todos? Sim, que esse oráculo tem por costume aconselhar a uns uma escola filosófica, a outros outra, conforme aquela que se lhe afigura mais adequada a cada consulente.

HERMOTIMO - Não foi nada disso, Licino, não consultei o deus... pelo menos a esse respeito.

LICINO - Mas será que não consideraste o assunto merecedor de consulta divina, ou julgaste ser capaz de, por tua conta e sem o auxílio do deus, escolher o melhor?

HERMOTIMO - De facto, julguei.

16. LICINO - Nesse caso, e em primeiro lugar, poderias ensinar-nos também a nós este ponto: como é que, logo de início, podemos reconhecer a melhor escola filosófica, aquela que diz a verdade, aquela que um homem pode escolher em detrimento das restantes.

HERMOTIMO - Vou explicar-te: como via a maior parte das pessoas acorrer a esta ${ }^{571}$, calculei que era ela a melhor.

LICINO - E quantos adeptos, aproximadamente, têm eles a mais que os epicuristas, ou que os platónicos, ou que os peripatéticos? Com certeza que os contaste, como nas votações de braço no ar.

${ }^{569}$ Crisipo (280-207 a. C.) foi um dos chefes do estoicismo e como que o seu segundo fundador. Dizia-se que tinha escrito uns 700 livros em defesa das suas ideias. Zenão (335-264 a. C.), que não devemos confundir com o igualmente famoso «Zenão, cruel Zenão, Zenão de Eleia», é considerado o fundador do estoicismo. Foi ele que passou a reunir os seus discípulos no Pórtico (gr. Stoá), em Atenas: daí a designação de "filosofia do Pórtico» ou "estoicismo».

${ }^{570}$ Querefonte era um dos mais íntimos amigos e discípulos de Sócrates. Foi a ele que o oráculo de Delfos declarou que Sócrates era o homem mais sábio... o que o nosso filósofo sempre se recusou a tomar à letra («Eu só sei que nada sei»).

${ }^{571}$ Refere-se, naturalmente, à filosofia estóica. Podemos concluir que, no tempo de Luciano, a propaganda estóica ganhava a todas as outras, apregoando belos princípios morais, em contraste com os defeitos e vícios das outras doutrinas. como se vê já a seguir. 
HERMOTIMO - Não, não os contei, mas calculei.

LICINO - O que tu não queres é elucidar-me: pelo contrário, estás a enganar-me, porquanto, em caso de tamanha gravidade, declaras julgar por cálculo e pela quantidade, furtando-te a falar-me com franqueza.

HERMOTIMO - Não foi só isso, Licino: também ouvia toda a gente dizer que os epicuristas eram sensuais e voluptuosos, que os peripatéticos eram ávidos de riquezas e quezilentos, que os platónicos eram orgulhosos e vaidosos, ao passo que, a respeito dos estóicos, a maioria das pessoas afirmava que eram corajosos, que sabiam tudo, e que só o homem que seguisse por tal caminho era rei, só esse era rico, só esse era sábio e reunia em si todas as virtudes.

17. LICINO - Quem te falava dessas escolas era com certeza gente estranha a elas... Sim, que tu não darias crédito a pessoas que estivessem a elogiar a sua própria.

HERMOTIMO - Claro que náo: eram opinióes de pessoas estranhas.

LICINO - Naturalmente que também não eram seus opositores.

HERMOTIMO - Não, não eram.

LICINO - Portanto, eram opinióes de pessoas comuns.

HERMOTIMO - Exactamente.

LICINO - Já vês como tentas de novo enganar-me e estás a faltar à verdade... Ou entáo cuidas que estás a discutir com algum Margites ${ }^{572}$ que acredite que Hermotimo, homem inteligente e, nesse tempo, com quarenta anos, confiou a gente comum um assunto de filosofia e de filósofos, e que foi de acordo com as suas opinióes que procedeu à escolha dos melhores. Não, não posso acreditar no que dizes.

18. HeRMOTIMO - Sabes, Licino..., não foi só nesses outros que eu confiei, mas também em mim próprio. De facto, via-os [aos estóicos] caminhar com modéstia, o manto discretamente subido, sempre a meditar, de aspecto viril, quase todos de cabelo rapado, sem nada de espampanante, mas também sem aquele excessivo desmazelo que até mete medo e é tipicamente

${ }^{572}$ Margites era a personagem, tornada proverbial, dum poema herói-cómico do mesmo nome. Resta-nos um fragmento, que diz: «Sabia muitas coisas, mas sabia todas mal». 
cínico ${ }^{573}$; pelo contrário, tinham um aspecto sobre o mediano, que toda a gente diz ser o melhor.

LICINO - Mas por acaso, Hermotimo, viste-os fazer coisas como as que ainda há pouco eu contei que vi fazer ao teu mestre? Por exemplo: emprestar dinheiro e exigi-lo com modos ásperos, discutir nas reunióes em termos quezilentos, enfim, tudo o mais em que as pessoas se revelam. Ou será que pouco te importam esses aspectos, desde que o manto esteja discretamente subido, a barba comprida e o cabelo rapado? Então, daqui para o futuro, em assunto táo grave, e de acordo com Hermotimo, vamos fixar este critério, esta regra segura: pela sua aparência exterior, maneira de andar e corte de cabelo, é que podemos distinguir os melhores; e todo aquele que não possua tais predicados, que não tenha um aspecto sombrio e um ar meditativo, deve ser reprovado e rejeitado!

19. Olha cá, Hermotimo: não estarás a brincar comigo, tentando ver se eu me apercebo de estar a ser "levado"?

HERMOTIMO - Que é que te leva a dizer isso?

LICINO - É que, meu caro, esse teste que referes, baseado nas aparências, é adequado às estátuas: sem dúvida que as de longe mais belas e mais bem vestidas são obra apurada dum Fídias, dum Alcámanes ou dum Míron. Porém... se é fundamentalmente com esses dados que temos de julgar, que aconteceria com uma pessoa que, sendo cega, pretendesse dedicar-se à filosofia? Como poderia ela determinar quem é que fez a melhor escolha, se não pode ver nem o seu aspecto exterior nem o seu modo de andar?

HERMOTIMO - Mas, ó Licino, eu não falo dos cegos: esses não me interessam.

LICINO - Seria conveniente, meu caro, adoptar um critério universal, que desse para assuntos desta importância e fosse utilizável por toda a gente. Todavia, se assim o preferes, deixemos os cegos fora da filosofia, uma vez que não vêem. (Em boa verdade, a estes ainda mais necessária se tornava a filosofia, para que não sofressem tanto com a sua desgraça.) Bem:

${ }^{573}$ Os cínicos defendiam e praticavam a pobreza total, punham-se voluntariamente à margem da sociedade «estabelecida», preservavam ferozmente a sua liberdade e não perdiam uma única ocasiáo de criticar tudo e todos. Além de Menipo, o nome mais conhecido é o de Diógenes, cuja personalidade chegou até nós através de cerca de um milhar de citaçōes dos antigos. 
quanto aos que vêem, e por muito penetrantes que sejam, como é que, a partir desta capa exterior, seriam capazes de detectar as virtudes da alma?

20. Mas o que eu quero dizer é o seguinte: não foi por amor $\mathrm{da}$ inteligência desses homens que tu os frequentavas, pretendendo aperfeiçoar-te também em inteligência?

HERMOTIMO - Com certeza.

LICINO - Então como é que, com base naqueles critérios que referiste, estavas em condiçóes de distinguir o verdadeiro filósofo daquele que o não era? Sim, que estas coisas não costumam ser assim tấo transparentes; pelo contrário, são secretas, não estão à vista, e só se revelam mediante a conversação, a convivência e os actos correspondentes - e mesmo assim só muito mais tarde e a custo. Com certeza que tens ouvido contar, creio eu, a censura que $\mathrm{Momo}^{574} \mathrm{fez}$ a Hefesto; se não ouviste, ouve agora: diz a lenda que Atena, Posídon e Hefesto se travaram de razóes sobre o mérito artístico [de cada um deles]. Posídon moldou um touro e Atena concebeu uma casa, enquanto Hefesto teria formado um homem; depois foram ter com Momo, que haviam elegido por árbitro; entâo este, após contemplar a obra de cada um... Bem: o que ele criticou nos outros dois seria supérfluo contar... mas, no que toca ao homem, censurou um aspecto e verberou o seu autor, Hefesto, pelo facto de não lhe ter feito umas janelas à altura do peito, de modo que, abertas estas, deixassem à vista de toda a gente os desejos e os pensamentos do homem: se estava a mentir ou a falar verdade. Isto era o que sobre os homens pensava Momo, que era fraco de vista; tu, porém, possuis uma vista mais penetrante que a de Linceu ${ }^{575}$ e, através do peito, vês, ao que parece, o nosso interior, que para ti está todo aberto... de forma que sabes não só o que cada homem quer ou pensa, mas também qual deles é melhor ou pior.

21. Hermotimo - Estás a brincar, Licino. Eu é que fiz a escolha, com a ajuda divina... e náo estou arrependido. Para mim é quanto basta.

LICINO - Mesmo assim, companheiro, não poderias dizer-me, também a mim? Ou vais abandonar-me, perdido no meio da arraia-miúda?

574 O deus Momo era, entre os deuses, uma espécie de "cínico».

${ }^{575}$ Linceu foi um dos argonautas, célebre pela agudeza da sua vista... de lince. 
Hermotimo - Mas se não te agrada nada do que eu diga...

LICINO - Não, meu caro, tu é que não estás disposto a dizer-me o que me agradaria [ouvir]. Por conseguinte, e já que deliberadamente dissimulas e tens inveja de mim, ainda assim não venha a ser tão bom filósofo como tu, eu mesmo vou tentar, a ver se sou capaz de, por mim próprio, descobrir o critério que se ajusta a este assunto e fazer então a escolha mais segura. Ora faz o favor de ir ouvindo.

HERMOTIMO - Mas sem favor, Licino. Vais talvez dizer algo de importante...

LICINO - Ora presta atenção e náo troces de mim por eu tratar o assunto em termos absolutamente leigos. Realmente, é fatal que assim seja, uma vez que tu, que sabes mais destas coisas, te recusas a falar com mais precisão.

22. Seja então a Virtude algo parecido com uma cidade, habitada (como diria o teu mestre, se de lá tivesse regressado) por cidadãos felizes, extraordinariamente sábios, todos corajosos, justos, prudentes, pouco faltando para serem deuses. Quanto aos muitos males que imperam entre nós (roubos, violência, ambição...), não verias um sequer que se aventurasse naquela cidade; pelo contrário, os concidadãos vivem em paz e harmonia... o que é natural, porquanto essas coisas que, a meu ver, nas outras cidades despertam dissensôes e rivalidades e são causa de traições mútuas, estão, todas elas, ausentes desses homens. Efectivamente, deixaram de encarar o ouro, os prazeres ou a glória como algo por que valha a pena lutar; ao invés, desde há muito que os baniram da sua cidade, por não os considerarem necessários à vida em sociedade, de modo que levam uma existência tranquila e completamente feliz, gozam de leis justas, igualdade, liberdade e todos os outros bens.

23. Hermotimo - E então, Licino, não será razoável que todos aspirem a tornar-se cidadãos duma tal cidade, sem olharem às penas da caminhada e sem sucumbirem perante a imensidáo de tempo [requerido para lá chegarem], só com o objectivo de, uma vez lá chegados, serem inscritos como cidadãos e participarem na vida da cidade?

LICINO - Sim, Hermotimo, por Zeus! Há que lutar, acima de tudo, por esse objectivo e desprezar os outros; não fazer grande 
caso da nossa pátria actual, que tenta reter-nos aqui; não nos deixarmos comover por filhos ou pais que se agarrem a nós a chorar: sobretudo a estes, há que convidá-los a empreender a mesma viagem, e, se eles não quiserem ou não puderem, há que sacudi-los e avançar direito a essa cidade venturosa; e se tentarem reter-nos, agarrados à nossa túnica, desfaçamo-nos dela e avancemos para a meta - e não tenhas receio, que ninguém te porá fora, se lá apareceres nu.

24. Um dia ${ }^{576}$, em tempos que já lá vão, ouvi um velho contar como se passam lá as coisas, e instou mesmo comigo para que o seguisse a essa cidade, dizendo que ele próprio me guiaria e, mal eu lá chegasse, me inscreveria, me faria membro duma tribo e me atribuiria a mesma fratria ${ }^{577}$ que ele, enfim, compartilharia da felicidade comum. "Mas eu nâo the dei ouvidos ${ }^{578}$ ", quer por estupidez, quer por ser então muito novo (andava aí pelos quinze anos). É possível que, neste momento, já me encontrasse pelos arredores, ou mesmo junto às portas. Ora, sobre esta cidade, contava ele, se bem me lembro, entre outras coisas, o seguinte: todos eram adventícios, estrangeiros, não havendo um autóctone sequer; pelo contrário, habitavam-na grande número de bárbaros, escravos, aleijados, pessoas humildes e pobres; numa palavra, qualquer um podia fazer parte da cidade. De facto, têm por lei proceder à inscrição sem olharem à fortuna, à condição social, à importância ou à beleza, ou ainda à família e à nobreza dos seus antepassados. Náo, tais coisas, para eles, náo contavam: para que cada um se tornasse cidadão, bastava-lhe possuir inteligência, paixão do bem, capacidade de trabalho, perseverança, um espírito que não cedesse nem se deixasse abater pelas muitas dificuldades que se deparam no caminho. Assim, todo aquele que revelasse tais qualidades e conseguisse percorrer todo o caminho até à cidade, imediatamente, fosse ele quem fosse, se tornaria cidadáo em parte inteira e igual a todos os outros. E quanto a conceitos como «inferior» e «superior», "nobre» ou

576 Inclino-me a pensar que Luciano alude aqui aos cristãos ou, de qualquer forma, a uma das muitas doutrinas de salvaçáo que floresciam por todo o Império Romano.

${ }^{577}$ Em Atenas, no tempo de Platão, havia quatro tribos, com três fratrias cada uma; a fratria era constituída por trinta famílias. Para o caso presente, interessa considerar, não os números, mas a organização social.

${ }^{578}$ Paródia a um passo da Ilíada. 
"plebeu», «escravo» ou «livre», são coisas que não existem nessa cidade, nem sequer são mencionadas.

25. HeRmotimo - Estás a ver, Licino, que não é sem motivo e por coisa de somenos que eu me afadigo, no meu desejo de tornar-me, também eu, cidadão duma cidade tão bela e tâo feliz?!

LICINO - Sim, Hermotimo, eu próprio estou apaixonado pela mesma ideia que tu, e não há coisa a que eu pudesse aspirar mais que a essa. Ora, se essa tal cidade estivesse próxima e à vista de toda a gente, podes ter a certeza de que há muito que eu teria dado entrada nela sem qualquer hesitaçấo, e seria agora seu cidadáo de longa data. Mas como, segundo as vossas palavras (tuas e do poeta Hesíodo), ela fica muito longe, há que procurar o caminho que a ela conduz, bem como o melhor guia. Não achas que é isso que devemos fazer?

HERMOTIMO - Sim, como poderia lá chegar doutra forma?

LICINO - Pois sim, mas no que toca a promessas e garantias de conhecerem o caminho, há uma grande abundância de candidatos a oferecerem-se para guias. Realmente, apresentam-se em grande número, e pressurosos, cada um deles afirmando-se natural dessa cidade. O caminho que se oferece é que não é um só e o mesmo, mas sim muitos e diversos, nada iguais uns aos outros: este parece apontar para ocidente, aquele para oriente, outro para o norte, aqueloutro no sentido sul; um, que atravessa prados, bosques e regiôes umbrosas, é abundante de águas, suave e sem qualquer obstáculo ou mau piso; outro é fragoso e rude, promete muito calor, muita sede e muita fadiga. E no entanto, todos eles, não obstante irem dar aos pontos mais díspares, são supostos conduzirem à tal cidade, que é uma única.

26. Ora, é justamente aí que reside todo o meu embaraço. Efectivamente, a qualquer um deles que eu me dirija, logo no início de cada vereda, e postado à entrada, encontra-se um homem, sem dúvida digno de crédito, que me estende a mão e me exorta a seguir a sua; cada um deles afirma ser o único que conhece a via verdadeira, e que os outros se extraviam, pois ainda nunca lá foram nem sequer seguiram outros capazes de os guiarem. E se me dirijo ao vizinho deste, também ele me faz idênticas promessas sobre o seu próprio caminho, dizendo mal dos outros; e o seguinte diz a mesma coisa, e assim sucessivamente todos os 
outros. Ora, o que não pouco me perturba e me causa embaraço é não apenas a quantidade de caminhos e a sua diversidade, mas sobretudo o facto de os guias se empenharem excessivamente no elogio dos respectivos caminhos. Assim, fico sem saber para qual me voltar, qual dos guias devo preferir para chegar à tal cidade.

27. Hermotimo - Deixa lá, que eu vou livrar-te de embaraço. Assim, Licino: se confiares nos que já anteriormente tenham feito a viagem, não podes enganar-te.

LICINO - Confiar em quais? Nos que percorreram um caminho - mas qual? Ou nos que já seguiram um dos guias mas qual? Em boa verdade, o mesmo problema é reposto sob outra forma, apenas transferido das coisas para as pessoas.

HERMOTIMO - Que queres dizer com isso?

LICINO - Que aquele que enveredou pela via de Platão, e seguiu viagem com ele, é evidente que louvará essa via; o que seguiu a de Epicuro, é essa que ele louvará: cada um a sua, e tu, lá a vossa. Então, Hermotimo, é ou não é assim?

HERMOTIMO - Como poderia deixar de ser?

LICINO - Nesse caso, ainda náo me livraste do meu embaraço, pois continuo na mesma sem saber em qual dos viajantes devo acreditar. De facto, verifico que cada um deles, incluindo o próprio guia, experimentou um único caminho, e é esse que ele louva, afirmando que só ele conduz à tal cidade. Náo tenho, pois, maneira de saber se fala verdade. Que ele tenha chegado a um destino qualquer e que tenha visto uma certa cidade, estou disposto a conceder-lhe... vá lá; agora se ele viu realmente aquela que era preciso ver, e da qual tu e eu aspiramos a ser cidadáos, ou se, pelo contrário, em vez de ir dar a Corinto, chegou mas foi a Babilónia e cuida estar a ver Corinto - eis o que me parece duvidoso. De facto, ver uma cidade não implica, de modo nenhum, ver Corinto... pelo menos se Corinto não é a única cidade [que existe]. O que, porém, me coloca no maior embaraço é o facto de saber que o caminho verdadeiro é necessariamente um único. Sim, que Corinto há só uma, pelo que todos os restantes caminhos conduzem a qualquer outra parte, que não a Corinto... a menos que haja alguém táo fora de siso, que cuide que tanto o caminho que aponta para os Hiperbóreos ${ }^{579}$, como o que aponta para a Índia, levam a Corinto.

${ }^{579}$ Hiperbóreos, isto é, «Nórdicos»... em relação ao mundo conhecido: povos que habitam a norte da Cítia. 
HeRmotimo - Como seria isso possível, Licino? De facto, cada caminho conduz a seu local.

28. LICINO - Por conseguinte, meu bom Hermotimo, a opção por um dos caminhos e guias requer uma náo pequena capacidade de decisão. Não vamos proceder segundo o dito "deixemo-nos ir para onde os nossos pés nos conduzirem»-, pois desse modo poderemos, sem dar por isso, estar a seguir, năo o caminho que leva a Corinto, mas o de Babilónia ou de Bactros. Efectivamente, não é sensato abandonarmos ao acaso a probabilidade de o caminho escolhido ser o melhor, [o que seria o caso] se nos lançássemos, sem ponderação, num único, qualquer que ele fosse. Verdade seja que tal coisa pode acontecer, e quem sabe se não aconteceu alguma vez no longo decurso do tempo... Todavia, e pelo menos em assunto de tamanha gravidade, náo creio que tenhamos necessidade de correr riscos temerariamente, ou de limitar fortemente a probabilidade, pretendendo, como diz o provérbio, «atravessar o Mar Egeu ou o Jónio num barco de vergan; a ser assim, náo poderíamos, razoavelmente, culpar o acaso pelo facto de este arremessar uma seta ou um dardo que não acertou justamente em determinado alvo, que é o único verdadeiro entre milhares doutros falsos - coisa que náo aconteceu nem ao arqueiro homérico, o qual, em vez de atingir a pomba, cortou o cordel: creio que foi Teucro ${ }^{580}$. É muito mais lógico esperar que a seta atinja e derrube uma coisa qualquer entre muitas, do que, entre todas, aquela precisamente. Julgo que te apercebes de que náo é pequeno o risco de, em vez do caminho que leva direito ao [objectivo], virmos, por ignorância, a cair num dos falsos, na esperança de que o acaso escolha por nós o melhor. Na verdade, uma vez feito ao largo e entregue ao vento, depois já não é fácil um homem regressar, voltar atrás e salvar-se; pelo contrário, não tem outro remédio senáo continuar no mar, enjoado até mais nâo, cheio de medo e com a cabeça à roda devido à agitação; o que se impunha previamente, antes de se fazer ao mar, era subir a um ponto elevado e observar se o vento estava de feição e favorável a quem pretendesse navegar para Corinto; e também, por Zeus!, escolher o melhor piloto e um navio sólido, capaz de resistir a tamanha agitação.

${ }^{580}$ Conhecido passo da Ilíada (XXIII, 865), a que Luciano alude de memória. 
29. HERMOTIMO - Assim, sim, Licino, é realmente muito melhor. No entanto, tenho a certeza de que, se os percorrermos a todos, um por um, não acharás melhores guias nem pilotos mais experimentados que os estóicos; e se quiseres chegar alguma vez a "Corinto», é a esses que seguirás, avançando no rasto de Crisipo e de Zenão ${ }^{581}$. Doutra forma é impossível.

LICINO - Estás a ver, Hermotimo, como acabas de falar a linguagem de toda a gente? Na verdade, isso precisamente é o que diria o companheiro de viagem de Platão, ou o que seguisse a Epicuro, e todos os outros: que eu não chegaria a "Corinto» senão na companhia de cada um deles. Assim sendo, há que, ou acreditar em todos (coisa bem ridícula), ou então desconfiar [de todos] por igual. De facto, esta última posição é de longe a mais segura, até que achemos o [homem] certo.

30. Senão vejamos: supóe que, sendo eu, como sou neste momento, ignorante sobre qual, dentre todos, é o que fala verdade, escolhia a vossa [escola], confiado em ti, pessoa amiga, mas que conhece exclusivamente a doutrina dos estóicos e que percorreu somente esse caminho; que, em seguida, algum dos deuses ressuscitava Platáo, Pitágoras, Aristóteles e os demais [filósofos], e que eles me cercavam e me submetiam a um interrogatório, ou até, por Zeus!, me levavam a tribunal, e cada um deles me acusava de insolência, dizendo: "Meu caro Licino: por que razão, ou confiado em quem, preferiste Crisipo e Zenão a nós, que somos muitissimo mais velhos que eles, que nasceram ontem ou anteontem, sem nos teres sequer dirigido uma palavra e sem teres tomado contacto [directo] com o nosso magistério?» Se eles me falassem nestes termos, que lhes responderia eu? Acaso me bastará alegar que fui persuadido por Hermotimo, pessoa minha amiga? De certeza que eles me diriam assim: "Licino: nós não sabemos quem seja esse tal Hermotimo, como ele também não nos conhece a nós. Por conseguinte, não devias acusar-nos a todos e condenar-nos arbitrariamente e à revelia, fiado num homem que, em matéria de filosofia, só aprendeu um sistema, e mesmo esse, talvez, incompletamente. Ora, não é essa, Licino, a maneira de proceder que os legisladores impóem aos juizes, isto é, que não oiçam a parte contrária, que não lhe permitam alegar em sua defesa o que ela entender ser-lhe favorável: pelo contrário, [ordenam] que escutem ambas por igual, a fim de que, confrontados

${ }^{581}$ Sobre Crisipo e Zenão, v. nota supra. 
os respectivos argumentos, possam distinguir a verdade da mentira; $e$, caso não procedam dessa forma, a lei confere-lhes a faculdade de apelar para outro tribunal.»

31. É natural que me falassem mais ou menos nesses termos. E talvez mesmo algum deles me pusesse mais uma questão: "Diz-me cá, Licino: se um etiope, que, pelo facto de nunca ter deixado o seu pais, jamais tivesse visto outros homens, como nós somos, dissesse e sustentasse, numa assembleia, que em parte alguma da Terra existiam homens brancos ou loiros, ou quaisquer outros que não fossem negros, porventura os outros lhe dariam crédito? Ou não se daria o caso de algum dos etiopes mais velhos lhe responder: "Como é que tu, homem atrevido, sabes isso? De facto, nunca saiste do nosso pais para qualquer outro, nem, por Zeus!, viste como são as coisas noutros paises." "Quanto a mim, diria que a pergunta do velho era justa. Qual é a tua opiniāo, Hermotimo?

HERMOTIMO - É essa: acho que o velho o censurava com toda a razão.

LICINO - Também acho, Hermotimo. O que se segue, porém, é que já não sei se merecerá a tua aprovação. A minha merece inteiramente.

HERMOTIMO - De que se trata?

32. LICINO - Certamente que o nosso homem ${ }^{582}$ prosseguirá, dizendo mais ou menos o seguinte: "Da mesma forma, suponha-se então, Licino, uma pessoa que conhece exclusivamente a doutrina dos estóicos, como, por exemplo, esse teu amigo Hermotimo, que nunca por nunca se deslocou ao "país" de Platão, de Epicuro ou, enfim, de qualquer outro. Ora, se essa pessoa afirmasse que não havia, nesses vários "paises", nem beleza nem verdade comparáveis com as do Pórtico e as suas doutrinas, não terias tu boas razóes para considerar atrevido quem assim se pronunciasse sobre todas as doutrinas, tanto mais que só conhecia uma única e nunca havia posto pé fora da sua "Etiópia"?» Que achas que lhe devia responder?

HERMOTIMO - A pura da verdade, claro: que sim senhor, nós estudamos, e muito bem, as doutrinas dos estóicos, de modo que nos reclamamos de filósofos segundo os seus princípios, mas nem por isso desconhecemos o que dizem os outros [filósofos], porquanto o nosso mestre também nos expóe, de passagem, tais doutrinas e as refuta com comentários de sua lavra.

${ }^{582}$ Quer dizer: o filósofo que Licino imagina ter tomado a palavra no $₫ 31$. 
33. LICINO - E cuidas tu que, nesse momento, ficarão calados os sequazes de Platão, de Pitágoras, de Epicuro e dos demais [filósofos]? E que não me diriam, no meio de gargalhadas: "Ó Licino, que disparate está a cometer esse teu amigo Hermotimo! Ach a ele bem acreditar no que a nosso respeito dizem os nossos adversários? Cuida ele que as nossas doutrinas são exactamente como esses fulanos afirmam, quando, de facto, ou não conhecem a realidade ou tentam escondê-la? Na mesma ordem de ideias, se ele visse um atleta, em treino preparatório da luta, a dar pontapés no ar ou a desferir golpes pugilísticos no vazio, como quem está a bater no adversário, será que, na sua qualidade de árbitro, o proclamaria vencedor, ou, pelo contrário, entenderia que, na ausência de qualquer opositor, tais [golpes] eram fáceis e sem perigo, e que a vitória só lhe poderia ser atribuida quando [realmente] defrontasse o próprio adversário, o vencesse e este se desse por vencido, e nunca doutro modo? Portanto, que Hermotimo, baseado nas falsas lutas que os seus mestres travam contra nós na nossa ausência, não cuide que eles levam a melhor ou que as nossas doutrinas são assim tão fáceis de rebater. Sim, que um tal processo seria comparável àquelas casinhas que os meninos constroem, sem firmeza, e que logo desmancham; ou, por Zeus!, aos individuos que se treinam no tiro ao arco, os quais fazem um boneco de palha, penduram-no numa lança, vão colocá-lo não muito longe, e depois fazem pontaria e disparam: sempre que acertam e trespassam o boneco, soltam gritos, como se tivessem cometido grande façanha, lá porque a seta atravessou a palha. Ora, não é assim que procedem os Persas, nem os arqueiros citas; ao invés, e antes de mais, eles próprios estão em movimento, disparando geralmente de cima dos seus cavalos; além disso, entendem que os alvos também devem mover-se, correr 0 mais possivel, em vez de estarem fixos, à espera que a seta os atinja. Na verdade, disparam as setas de preferência sobre animais selvagens, e alguns visam mesmo as aves. E se porventura têm de experimentar as força de tiro no alvo, colocam uma prancha de madeira resistente, ou um escudo, que tentam varar, assim se assegurando de que as suas setas atravessarão as armas [inimigas]. Portanto, Licino, diz da nossa parte a Hermotimo que os seus mestres colocam "bonecos de palha" para os seus "disparos" e que depois vêm afirmar que venceram homens armados; [diz-lhe] que eles "desenham imagens" das nossas pessoas, thes "dão socos" e, ao levarem a melhor sobre elas, julgam naturalmente que nos vencem. Cada um de nós é que thes poderia dizer as célebres palavras que Aquiles pronunciou a propósito de Heitor: 
Isto é o que eles diriam - todos em geral e cada um em particular.

34. No entanto, Platão - creio eu - contaria mesmo uma das suas anedotas da Sicília, como pessoa que sabe muitas. Por exemplo: "Dizem que Gélon de Siracusa cheirava mal da boca - facto de que, durante muito tempo, não se apercebera, pois ninguém ousava advertir um tirano... até que certa mulher estrangeira, que tivera relaçóes com ele, se atreveu a dizer-lhe o que se passava. Então Gélon foi procurar a sua própria mulher e zangou-se com ela por náo o ter avisado, já que certamente sabia do seu mau hálito. Ela, porém, pediu-lhe que a desculpasse, porquanto, como ainda nunca tinha tido qualquer experiência com outro homem, nem havia jamais falado de perto com nenhum, julgava que todos os homens exalavam tal cheiro da boca. Da mesma forma, também Hermotimo - diria Platão -, uma vez que se dá exclusivamente com os estóicos, naturalmente desconhece como são as "bocas" dos outros.» Quanto a Crisipo, também falaria em termos idênticos, ou ainda mais fortes, se acaso eu, sem julgamento, o tivesse desprezado e me virasse para as doutrinas platónicas, fiado em algum dos que só tivessem frequentado Platão. Numa palavra, e em resumo, afirmo que, enquanto subsistir a dúvida sobre qual das escolas filosóficas é a verdadeira, não devemos optar por nenhuma, visto que um tal acto constituiria uma ofensa feita às outras.

35. Hermotimo - Por Vesta, Licino, deixemos em paz Platão, Aristóteles, Epicuro e os demais, pois não estou para refutá-los [a todos]. Examinemos antes, nós dois, eu e tu, por nós próprios, se essa coisa da filosofia é tal qual eu afirmo que é. Quanto aos etíopes... e particularmente quanto à mulher de Gélon, que tinhas tu de fazê-la vir à colação, lá de Siracusa?

LICINO - Pois bem, deixemos esses de fora, se entendes que eles estão a mais na discussão. Mas agora fala tu, que tens ar de quem vai dizer uma coisa maravilhosa.

Hermotimo - Creio, Licino, que é muito possível, para quem estudou apenas as doutrinas estóicas, conhecer a verdade com base nestas, mesmo que náo tenha percorrido as dos

${ }^{583}$ Citação da Ilíada, XVI, 70. 
outros, estudando-as uma por uma. Considera o seguinte: se uma pessoa te disser simplesmente isto: que duas vezes dois perfazem o número quatro, acaso precisarás de andar dum lado para outro a informar-te junto de quantos matemáticos existem, não vá dar-se o caso de haver algum que diga que são cinco ou sete? Será que não ficarias imediatamente a saber que o homem fala verdade?

LICINO - Imediatamente, Hermotimo.

HERMOTIMO - Então por que raio te parece impossível que uma pessoa, em contacto apenas com estóicos que falam verdade, acredite neles e não tenha mais necessidade dos outros [filósofos], ciente de que "quatro» nunca na vida poderiam ser "cinco», ainda que mil Platôes ou Pitágoras o afirmassem?

36. LICINO - Isso, Hermotimo, não tem nada com o caso. $\mathrm{Na}$ verdade, estás a comparar factos reconhecidos com coisas controversas e absolutamente diferentes. Então que dirias tu... Já alguma vez encontraste alguém que afirmasse que duas vezes dois fazem sete ou perfazem o número onze?

Hermotimo - Eu não. Estaria louco quem não dissesse que isso dá quatro.

LICINO - E então? Já alguma vez encontraste um estóico, ou um epicurista (pelas Graças, tenta ser sincero!), que não divergisse no que toca aos princípios ou aos fins?

HERMOTIMO - De forma nenhuma.

LICINO - Nesse caso... vê lá, meu caro, não estejas a induzir-me em erro, apesar de eu ser teu amigo. Efectivamente, estando nós a investigar quais é que falam verdade em matéria de filosofia, tu antecipaste-te e atribuíste esse [privilégio] aos estóicos, dizendo que foram eles quem determinou que «duas vezes dois são quatro" ${ }^{584}$ - apesar de não ser evidente que as coisas se passassem assim. De facto, os epicuristas ou os platónicos diriam que eles é que chegaram a esse resultado, ao passo que [segundo eles] vós ${ }^{585}$ afirmais que são cinco, ou sete... Não achas que é isso mesmo que acontece, quando vós considerais que só o belo é bom, enquanto os epicuristas dizem que o prazer é que é? Ou quando vós dizeis que tudo é matéria, enquanto Platão acredita que há nos seres algo de imaterial? Tu, porém, como eu dizia, pegas, com a maior arrogância, numa matéria

${ }^{584}$ É claro que o exemplo se refere a verdades evidentes em geral.

585 vós... estóicos. 
controversa e, como se ela fosse indiscutivelmente propriedade dos estóicos, atribuis a estes a sua paternidade, apesar dos protestos dos outros, que também reivindicam a sua posse enquanto eu opino que há necessidade absoluta de proceder a um debate. Se resultar claro o facto de os estóicos serem os únicos a considerar que "duas vezes dois são quatro", é esse o momento de os outros se calarem; mas, enquanto eles discutirem o assunto, há que ouvi-los a todos por igual, sem o que passaremos por fazer um julgamento parcial.

37. HeRMOTIMO - Ó Licino, não me parece que estejas a perceber o que eu pretendo dizer.

LICINO - Nesse caso, tens de exprimir-te com mais clareza... se é que vais dizer algo de diferente, e não pouco mais ou menos a mesma coisa.

Hermotimo - Já vais ver o que eu pretendo dizer. Admitamos que dois indivíduos entraram no templo de Asclépio ou no santuário de Dioniso, e que, depois, desapareceu uma taça sagrada. Vai ser preciso, com certeza, revistar a ambos, a ver qual deles tem a taça escondida sob o manto.

LICINO - Muito bem.

HERMOTIMO - Um dos dois tem-na, certamente.

LICINO - Como não, se ela desapareceu?!

HERMOTIMO - Por conseguinte, se a encontrares na posse do primeiro, já não irás despir o segundo: é evidente que este não a tem.

LICINO - É evidente, pois claro.

Hermotimo - E se não a encontrássemos no manto do primeiro, o outro tem-na com certeza, e nesse caso também não há qualquer necessidade de procurar.

LICINO - Se é esse que a tem...

HERMOTIMO - Portanto, também nós, se encontrássemos a "taça» em poder dos estóicos, deixaríamos de achar necessário procurar junto dos outros, uma vez que já tínhamos o que há muito procurávamos. Sim, porque é que haveríamos de continuar com mais canseiras?

38. LICINO - Não haveria motivo para tal, se de facto a encontrássemos e, uma vez encontrada, estivésseis em condiçóes de saber que esse era o objecto desaparecido, ou se o objecto sagrado fosse por vós reconhecido sem sombra de dúvida. No presente 
caso, porém, ó companheiro, em primeiro lugar não são duas as pessoas que entraram no templo ${ }^{586}$ (caso em que, necessariamente, uma delas tem o objecto roubado), mas sim muitas; depois, e no que toca propriamente ao objecto desaparecido, náo é claro de que objecto se trata: se uma taça, um cálice ou uma coroa. Pelo menos, de entre todos os sacerdotes ${ }^{587}$, cada um diz sua coisa, e não estáo de acordo nem sequer no que respeita à matéria de que ele é feito: uns afirmam que é de cobre, outros que é de prata, outros de oiro, outros de estanho. Portanto, se queres descobrir o objecto desaparecido, torna-se necessário despir todos os que entraram [no templo]. Efectivamente, mesmo que aches, logo no primeiro, uma taça de oiro, ainda assim tens de despir os outros.

\section{HERMOTIMO - Mas porquê, Licino?}

LICINO - Porque não é evidente que o objecto desaparecido seja uma taça. E mesmo que tal fosse reconhecido por todos, acontece que nem todos afirmam que a taça é de ouro. E ainda que ficasse perfeitamente estabelecido que a taça desaparecida era de ouro e que tu encontrasses na posse do primeiro uma taça de ouro, nem mesmo assim cessarias de revistar os outros, pois náo é líquido que essa fosse a do deus. Ou náo achas que há muitas taças de ouro?

HERMOTIMO - Acho, pois.

LICINO - Será preciso, claro, revistar toda a gente e, uma vez colocados à vista todos os objectos achados em poder de cada pessoa, determinar qual deles deveremos considerar propriedade divina.

39. Mas o que me está a causar grande embaraço é o facto de cada pessoa a ser despida possuir seguramente algo: uma tem um cálice, outra uma taça, outra outra coisa; uma tem um objecto de cobre, outra de ouro, outra de prata. Se aquilo que cada uma tem em seu poder é o objecto sagrado, eis o que ainda não é líquido. Donde é fatal que te sintas embaraçado para acusar um qualquer de sacrilégio; e mesmo no caso de todos terem em seu poder objectos iguais, continuaria, ainda assim, duvidoso qual a pessoa que havia furtado o do deus, uma vez que é possível possuí-los em propriedade privada. A causa da nossa ignorância é só uma, creio eu: o facto de a taça desaparecida (admitamos

${ }^{586}$ Quer dizer: não existem apenas duas escolas filosóficas...

587 Ou seja: filósofos. 
que foi uma taça que desapareceu) não conter qualquer inscrição, de forma que, se nela estivesse gravado o nome do deus ou o do ofertante, teríamos menos trabalho, porquanto, uma vez achada aquela que contivesse a inscrição, cessaríamos de despir e incomodar os outros. Mas, Hermotimo, julgo que já tens assistido muitas vezes a jogos gímnicos.

Hermotimo - E julgas bem: sim, muitas vezes e em muitos locais.

LICINO - E alguma vez, por acaso, ficaste sentado mesmo junto dos juízes dos jogos? ${ }^{388}$

HeRMOTIMO - Sim, por Zeus!, ainda há pouco tempo, em Olímpia, fiquei à esquerda dos Juízes Nacionais ${ }^{589}$. Evândrides de Élide reservou-me um lugar entre os seus concidadãos. Efectivamente, eu desejava observar de perto a acção dos Juízes Nacionais.

LICINO - Nesse caso, também sabes como é que tiram à sorte quem tem de disputar com quem, na luta ou no pancrácio.

HERMOTIMO - Claro que sim.

LICINO - Portanto, és tu a pessoa indicada para contar como as coisas se passam, já que as viste de perto.

40. Hermotimo - Antigamente, quando Héracles presidia aos jogos, eram folhas de louro que...

LICINO - Ó Hermotimo, deixa-te lá do antigamente e conta-me mas é o que viste de perto.

HERMOTIMO - À sua frente coloca-se uma urna de prata dedicada ao deus, e dentro dela lançam umas fichas pequenas, mais ou menos do tamanho de favas, com letras gravadas. Em duas dessas fichas escreve-se um Alfa, noutras duas um Beta, noutras duas um Gama, e assim por diante, da mesma forma, se houver mais atletas, mas ficando sempre duas fichas com a mesma letra. Então, cada um dos atletas avança, faz uma prece a Zeus, mete a mão na urna e retira uma das fichas. A seguir a esse vem outro. Um agente da ordem ${ }^{590}$, colocado junto de cada [concorrente], segura-lhe a mão, não o deixando tomar conhecimento da letra que retirou. Quando já todos têm a sua ficha, o agente da autoridade ${ }^{591}$, creio eu, ou um dos juízes

588 O termo técnico grego é athlothétês, "atlóteta», pl. athlothétai.

589 Hellanodikês, "Helanódice», pl. Hellanodikai.

590 mastigophóros, "mastigóforo", lit. ${ }^{\text {te }}$ "portador de chicote».

${ }^{591} \mathrm{Ou}$ «o agente da ordem»: o termo é o mesmo (v. nota precedente). 
nacionais (já não me recordo deste pormenor), dá a volta pelos atletas, que estão em círculo, vê as fichas, e assim reúne, quer para a luta, quer para o pancrácio, aquele que tem um $A l f a$ com o que retirou outro $A l f a$, aquele que tem um Beta também com o [outro] Beta, e da mesma forma todos os outros que têm a mesma letra... isto, se os competidores forem em número par, como oito, ou quatro, ou doze; mas, se forem em número ímpar (cinco, sete, nove...), é lançada, no meio das outras, uma letra suplementar gravada numa única ficha, e que não tem letra correspondente. Aquele que retirar esta letra fica de parte, esperando que os outros tenham competido, uma vez que não tem letra correspondente - circunstância que constitui para esse atleta uma sorte nana pequena: o facto de, ainda fresco, ir defrontar adversários já fatigados ${ }^{592}$.

41. LICINO - Pára aí, que disso mesmo é que eu precisava. Portanto, e supondo que são nove [os atletas], todos eles já retiraram e têm na máo as fichas. Entáo tu (pois quero fazer de ti Juiz Nacional, em vez de espectador), dás a volta e observas as letras, mas, creio eu, não podes saber antecipadamente qual é o sobrante, sem que os tenhas percorrido todos e os agrupes.

HERMOTIMO - Porque afirmas isso, Licino?

LICINO - É impossível achar logo aquela letra que designa o sobrante... ou talvez encontres essa letra, só que não saberás se é essa, uma vez que náo ficou previamente estabelecido que era o $K a p a$, ou o Mi, ou o Iota que designavam o sobrante. Ora, ao dares com um Alfa, procuras aquele que tem o outro Alfa e, uma vez encontrado, ficas com esses reunidos num par; ao dares depois com o Beta, procuras onde está o segundo Beta (adversário do já encontrado), e assim com as demais [letras], até que te restará aquele [atleta] que tem a única letra sem antagonista.

42. Hermotimo - E entáo, no caso de dares, logo à primeira ou à segunda vez, com essa letra, que farás?

LICINO - Eu não, mas sim tu, que és Juiz Nacional... Pretendo saber o que é que tu farás: se dirás imediatamente que este é o sobrante, ou se será preciso percorrê-los a todos à volta, a ver se porventura haverá uma letra igual a essa. Sim, se não verificares as fichas de todos [os atletas], não poderás saber qual o sobrante.

${ }^{592}$ Aqui, não podemos deixar de notar a injustiça do sorteio... 
Hermotimo - Mas sim, Licino, seria fácil de saber: no caso de serem nove, se, à primeira ou à segunda, eu achar o Épsilon, fico a saber que aquele que o tem é o sobrante.

LICINO - Como é isso, Hermotimo?

Hermotimo - Assim: dois deles têm o Alfa, outros dois o Beta; dos restantes, que são quatro, dois com certeza que retiraram o Gama, e dois o Delta; e [com isto] já temos distribuídas quatro letras pelos atletas, em número de oito. É, pois, evidente que, deste modo, só a letra seguinte, o Épsilon, poderia ser o sobrante, pelo que aquele que o retirou é o sobrante.

LICINO - Ó Hermotimo! Devo felicitar-te pela tua inteligência, ou preferes que eu contra-argumente segundo as minha ideias?

Hermotimo - Sim, por Zeus! No entanto, custa-me imaginar que argumento razoável poderás contrapor ao meu.

43. LICINO - Na realidade, tu falas como se todas as letras fossem escritas de enfiada, por exemplo: primeiro o Alfa, em segundo lugar o Beta, e assim por diante, segundo a sua ordem [alfabética], até que uma delas terminasse o número de atletas. Bem... concedo-te que é assim que as coisas se passam em Olímpia. No entanto, supondo que escolhíamos, de entre todas, cinco letras fora da sua ordem, por exemplo, o Xis ${ }^{593}$, o Sigma, o Zeta, o Kapa e o Theta, e que escrevíamos quatro [delas] em duplicado nas oito fichas, mas um único Zeta na nona (aquela que indica quem será o nosso sobrante), que farás ao dar, logo à primeira, com o Zeta? Como saber que aquele que a tem é o sobrante, sem [primeiro] ter percorrido todos [os atletas] e constatado que não há nenhuma letra que lhe corresponda? $\mathrm{Na}$ verdade, não poderias, como ainda agora, fundamentar-te na ordem alfabética.

HERMOTIMO - É difícil responder a essa questão.

44. LICINO - Ora bem, considera a mesma questão, mas sob outra forma: como seria, se nas fichas escrevêssemos, não as letras, mas quaisquer outros sinais ou marcas, como os que, em grande número, gravam os egípcios em vez de letras - pessoas com cabeça de câo, ou cabeça de leão...? Ou então... deixemos essas figuras, já que são bizarras. Vá lá: desenhemos coisas de aspecto definido e simples e representemo-las o melhor possível:

${ }^{593} \mathrm{O}$ nome da letra, na adaptação port., é Qui. Na sua forma grega, trata-se das letras $\mathrm{X}, \Sigma, \mathrm{Z}, \mathrm{K}, \Theta$. 
figuras humanas em duas fichas, dois cavalos noutras duas, dois galos, dois cães; quanto à nona ficha, seja a marca um leão. Ora, se, logo à primeira, deres com a ficha que tem o leão, como poderás afirmar que é essa que designa o sobrante, se náo comparares todas elas, a ver se mais alguma tem um leáo?

HERMOTIMO - Náo sei que responder-te, Licino.

45. LICINO - Obviamente, pois não existe resposta plausível. Portanto, se quisermos descobrir quem tem a taça sagrada, ou o sobrante, ou quem melhor nos guie à tal cidade de Corinto, forçosamente que nos dirigiremos a todos eles, e a todos examinaremos, investigando exaustivamente, despindo-os e comparando-os... e mesmo assim, só a muito custo saberíamos a verdade. E mesmo que houvesse por aí alguém, um conselheiro que me merecesse crédito e que, no caso da filosofia, me aconselhasse qual é que eu devia professar, esse só poderia ser uma pessoa que conhecesse o que dizem todas elas; os outros deixam muito a desejar, e não lhes daria crédito, mesmo que desconhecessem apenas uma única doutrina: sim, quem sabe se não seria [precisamente] essa a melhor. Efectivamente, se alguém nos apresentasse um belo homem e afirmasse que esse é o homem mais belo de todos, não lhe daríamos crédito, a menos que soubéssemos que ele já tinha visto todos os homens. Sim, talvez seja belo, mas o que o outro náo podia, sem os ver a todos, era saber se ele é o mais belo de todos. Ora, do que nós precisamos não é de algo simplesmente belo, mas sim de o mais belo; e, enquanto náo o encontrarmos, náo julgamos poder classificar seja o que for como «mais». A verdade é que não nos satisfaremos com qualquer coisa bela que nos apareça, mas antes procuramos a suprema beleza, que necessariamente é uma única.

46. Hermotimo - É verdade.

LICINO - E então? És capaz de me indicar alguém que, em matéria de filosofia, já tenha experimentado todas as vias e que, conhecedor das doutrinas de Pitágoras, de Platáo, de Aristóteles, de Crisipo, de Epicuro e dos outros, finalmente tenha escolhido, dentre todas essas vias, uma única, que ele aprovou como verdadeira e que sabe, por experiência, que essa e só essa conduz em direcçáo à felicidade? De facto, se encontrássemos alguém nessas condiçóes, acabavam os nossos problemas.

HERMOTIMO - Não é fácil, Licino, encontrar um homem assim. 
47. LICINO - Então que faremos, Hermotimo? Na verdade, não acho que seja caso para desistirmos, só pelo facto de não dispormos, pelo menos de momento, dum tal guia. Não será, de entre todos os métodos, o melhor e mais seguro aquele que consiste em cada pessoa começar a percorrer todas as escolas e observar com rigor as respectivas doutrinas?

Hermotimo - Pelo menos é o que parece decorrer deste debate. Mas atenção, não vá essa tua ideia, atrás exposta, tornar-se contraproducente, a ponto de não ser fácil um homem voltar atrás, depois de lançado no caminho e de ter desfraldado a vela. Sim, como é que poderia percorrer todos os caminhos uma pessoa que, como tu dizes, viesse a ficar presa no primeiro?

LICINO - Vou explicar-te. Imitaremos o célebre expediente de Teseu $^{594}$ : arranjamos um fio de linho, fornecido pela Ariadne trágica ${ }^{595}$, e assim penetraremos em cada um dos "labirintos"; depois, enrolando-o, é possível sair sem dificuldade.

HeRMotimo - Mas quem poderia ser a nossa "Ariadne"? E aonde iremos buscar um "fio de linho"?

LICINO - Calma, companheiro, que me parece ter já encontrado algo a que nos agarremos e que nos facultará a saída.

HERMOTIMO - Que coisa é essa?

LICINO - Devo dizer-te que não é coisa minha, mas de um dos sábios; trata-se do "Sê prudente e desconfiado» ${ }^{596}$. De facto, se não acreditarmos facilmente no que formos ouvindo, mas antes nos comportarmos como os juízes, isto é, dando também a palavra aos que vierem a seguir, talvez consigamos escapar dos [vários] "labirintos".

HeRMOTIMO - Dizes bem: procedamos dessa forma.

48. LICINO - Pois seja. Então a qual deles nos dirigiremos em primeiro lugar? Ou será completamente indiferente este ponto? Começando por um qualquer, como, por exemplo, Pitágoras, se calhar assim, dentro de quanto tempo consideraremos poder aprender toda a doutrina pitagórica?... Mas não me

594 Teseu penetrou no labirinto de Creta, donde depois saiu com o artifício do fio que ia desenrolando à medida que prosseguia, e que permitiria encontrar o caminho de regresso.

595 Ariadne foi quem forneceu o fio a Teseu. Aqui Luciano deve referir-se a alguma representação trágica, na qual a heroína aparece com o novelo e o entrega a Teseu.

${ }^{596}$ Citação do poeta cómico Epicarmo. 
subtraias os tais cinco anos de silêncio! ${ }^{597}$ Portanto, incluindo esses cinco anos, julgo que trinta anos serão suficientes, ou, vá lá, pelo menos uns vinte.

HERMOTIMO - Suponhamos que sim.

LICINO - Seguidamente, há que fixar para Platão, obviamente, outros tantos anos, e com certeza que náo menos para Aristóteles.

HERMOTIMO - Claro que não.

LICINO - Quanto a Crisipo, nem te vou perguntar quantos anos daremos, pois sei, por ter ouvido da tua boca, que dificilmente bastariam quarenta ${ }^{598}$.

HERMOTIMO - Precisamente.

LICINO - Seguidamente, é a vez de Epicuro e dos outros [filósofos]. Que os números que eu proponho não são muito elevados, é o que tu depreenderás, ao considerar a quantidade de octogenários estóicos, ou epicuristas, ou platónicos, os quais confessam, cada um por seu lado, que não conhecem todas as doutrinas das respectivas escolas, a ponto de não precisarem mais de as estudar. À falta destes, a mesma coisa confirmariam certamente Crisipo, Aristóteles, Platão e, ainda mais que estes, Sócrates, que vale por todos, o qual costumava apregoar a toda a gente que não só não sabia tudo, como não sabia absolutamente nada, ou que apenas sabia uma coisa: que não sabia [nada]. Façamos, pois, as contas desde o princípio: pusemos vinte anos para Pitágoras, depois, para Platão, outros tantos, e assim por diante para os outros. Portanto, tudo somado, e supondo que fixámos em dez o número de escolas filosóficas, quantos anos seriam no total?

Hermotimo - Mais de duzentos, Licino.

LICINO - Queres que lhe retiremos um quarto, de forma que já nos contentássemos com cento e cinquenta anos? Ou toda uma metade?

49. Hermotimo - Tu deves saber melhor [que eu]. No entanto, estou a ver uma coisa: que, desse modo, poucos as percorreriam a todas, mesmo começando logo à nascença.

LICINO - E que é que se pode fazer, Hermotimo, se as coisas são como são? Ou será caso para reconsiderarmos aquilo em

597 Como se vê, o magistério de Pitágoras incluía uma iniciação de cinco anos de silêncio, a que Luciano alude com certo requinte de ironia.

${ }^{598}$ No $\$ 6$, Hermotimo calcula «não mais de vinte anos», mas a juntar aos vinte que já leva de estudo da doutrina estóica. 
que já havíamos acordado, ou seja, que não se pode escolher, de entre muitas coisas, a melhor, se não se tiverem experimentado todas? Mais: aquele que, na busca da verdade, escolhe experimentar, fá-lo mais por palpite que por critério racional. Não era isso que dizíamos?

HERMOTIMO - Sim.

LICINO - Portanto, é de absoluta necessidade vivermos longo tempo, se nos propomos, após experimentar todos [os filósofos], fazer uma boa escolha; e. após a escolha, passar à prática filosófica; e [finalmente], por meio da filosofia, atingir a felicidade. A não procedermos assim, dançaríamos, como sói dizer-se, nas trevas, chocando com o que calhasse, e, por náo conhecermos a verdade, tomaríamos pelo objectivo procurado a primeira coisa que nos viesse às mãos. Aliás, mesmo que, por algum feliz acaso, nela tropeçássemos e assim a achássemos, náo estaríamos em condiçôes de saber com certeza se essa coisa era aquela que procurávamos. De facto, há muitas coisas semelhantes entre si, cada uma delas com a pretensão de que é a verdadeira por excelência.

50. Hermotimo - Não sei lá como, Licino, mas as tuas palavras parecem-me razoáveis. Contudo - seja dito com franqueza -, tu afliges-me, e não pouco, ao esmiuçares o assunto, tratando-o com uma precisão desnecessária. Até parece (sei lá!) que saí hoje de casa já mal fadado e que, ao sair, já estava marcado o encontro contigo; e que tu, justamente quando eu já estava perto da concretização das minhas esperanças, me havias induzido em dificuldades, ao demonstrares que é impossível achar a verdade, já que essa tarefa requer um tão grande número de anos.

LICINO - Pois, companheiro, quem tu, com mais justiça, devias criticar, era teu pai Menécrates e tua mãe... lá como ela se chamava (não sei o nome), ou até mesmo, e muito antes, a natureza humana, pelo facto de não te terem feito, como a Titono ${ }^{599}$, longevo, macróbio; pelo contrário, determinaram que cada ser humano não vivesse mais de cem anos, no máximo. Ora, o que eu, neste exame a que procedi contigo, descobri, foram apenas as consequências do raciocínio.

51. HERMOTIMO - Mas não! Tu é que não passas dum insolente e, não sei por que razão, odeias a filosofia e troças dos filósofos.

599 Titono: personagem lendária, a quem Zeus concedeu a graça de viver mais que o comum dos mortais. 
LICINO - Ó Hermotimo! O que é a verdade, vós, os sábios, ou seja, tu e o teu mestre, melhor que eu o direis. Quanto a mim, porém, sei ao menos isto: que ela não é lá muito agradável de ouvir e que, por outro lado, é geralmente difamada pela mentira. Realmente, esta última tem melhor aspecto e, por isso mesmo, é mais agradável, enquanto aquela, por náo pactuar com qualquer forma de falsidade, fala às pessoas com franqueza, e por isso as pessoas se mostram ofendidas com ela. Ora vê lá: também tu agora estás ofendido comigo, por eu, [aliás] com o teu concurso, ter descoberto a verdade a respeito do nosso tema e por ter demonstrado que aquilo que eu e tu amamos não é nada fácil [de alcançar]. É como se tu viesses a apaixonar-te por uma estátua e julgasses poder conseguir os seus favores, convencido de que ela era um ser humano; então eu, verificando que se tratava de pedra ou de bronze, avisava-te, por caridade, de que essa paixão era impossível, e nesse momento tu ficavas a pensar que eu te queria mal, ao não permitir que tu viesses a ficar decepcionado por pores as tuas esperanças em coisas bizarras e sem futuro.

52. Hermotimo - Queres tu dizer com isso, Licino, que não devemos dedicar-nos à filosofia, mas antes entregar-nos à ociosidade e passar a viver como simples mortais? ${ }^{600}$

LICINO - Onde é que me ouviste dizer tal coisa? Na realidade, o que eu afirmo não é que não devemos dedicar-nos à filosofia, mas sim (já que temos de fazê-lo; já que são muitos os caminhos para a filosofia, cada um deles reclamando-se de conduzir à virtude; já que [finalmente] a verdade náo se manifesta claramente em nenhum deles) que temos é de fazer a escolha certa. Todavia, dada a quantidade das propostas, parece-nos impossível escolher a melhor, a menos que se percorressem todas à experiência. Depois, verificou-se que essa experiência era algo demorada. Então... que é que achas? Vou perguntar-te de novo: seguirás e estudarás filosofia com o primeiro que encontrares, o qual fará de ti uma presa?

53. HERMOTIMO - Que mais poderei responder-te, se tu, por um lado, afirmas que ninguém está em condiçôes de julgar por si próprio (a menos que atinja a idade da Fénix ${ }^{601}$, para poder

${ }^{600}$ Vai ser essa, precisamente, a conclusão final.

601 Fénix: ave fabulosa da mitologia egípcia; depois de viver vários séculos, imolava-se pelo fogo e renascia a seguir das próprias cinzas. 
percorrer cada uma por sua vez) e, por outro lado, entendes que não devemos dar crédito nem aos que já antes fizeram a experiência nem aos muitos que louvam e dão testemunho [da sua]?

LICINO - E quem são esses muitos, que tu afirmas conhecerem e terem experimentado todas as escolas? Se, efectivamente, existe alguém nessas condiçóes, um único já me basta, não precisarei de muitos. Se, porém, mencionares pessoas que não as conhecem [a todas], o seu número não me induzirá a dar-lhes crédito, enquanto elas (que, afinal, ou não conhecem nenhuma, ou só conhecem uma) não me fizerem a exposição de todas.

HERMOTIMO - Pois sim... tu és o único que viu completamente a verdade, e todos os outros que estudam filosofia são estúpidos.

LICINO - Ó Hermotimo, estás a caluniar-me, ao dizeres que eu me coloco, dalgum modo, acima dos outros ou que decididamente me incluo no número dos sábios. Não estás recordado do que eu afirmei: que náo pretendo conhecer a verdade melhor que as outras pessoas, mas antes confesso que, como toda a gente, a desconheço.

54. Hermotimo - Vamos lá, Licino: a necessidade de percorrer todas as escolas, de experimentar o que elas dizem e não seleccionar a melhor sem ser por essa forma, talvez seja uma coisa razoável; mas dedicar tantos anos a cada experiência, isso é que é completamente ridículo... como se não fosse possível conhecê-las todas com base em pequenas amostras [de cada uma]. Ora, tal processo afigura-se-me bastante simples e náo requer muito tempo. Conta-se até que certo escultor (creio que Fídias), ao ver apenas uma unha de leão, por ela calculou qual seria o tamanho de todo o leáo, desde que modelado na escala da unha. Tu próprio, se alguém te mostrar apenas uma mão humana, escondendo o resto do corpo, saberás imediatamente, creio eu, que a parte escondida é dum homem, ainda que náo vejas o corpo todo. Assim também, é fácil de aprender, numa pequena fracção do dia, os pontos essenciais de cada doutrina; quanto aos pormenores, que requerem um exame prolongado, não são necessários à escolha da melhor, pois é possível formar um juízo com base nesses [pontos essenciais].

55. LICINO - Eh lá, Hermotimo! Com que segurança afirmas uma coisa dessas, arrogando-te a possibilidade de conhecer o todo pelas partes! E no entanto, recordo-me de te ter ouvido dizer 
o contrário: que quem conhece o todo também conhece a parte, mas já quem conhece apenas a parte náo conhece o todo. Ora responde-me lá ao seguinte: será que Fídias, ao ver uma unha de leão, poderia saber que era de leão, se nunca na vida tivesse visto um leão completo? E tu, se visses uma mão humana, serias capaz de dizer que era de homem, se previamente não conhecesses e não tivesses visto um homem? Porque te calas? Ou preferes que eu dê, em teu lugar, a resposta forçosa, ou seja, que não serias capaz? Deste modo, parece-me que o teu Fídias $^{602}$, por inútil, foi-se por água abaixo, depois de inutilmente esculpir o leão, dizendo: "Realmente, isto não tem nada que ver com Dioniso» ${ }^{603}$. Sim, em que é que uma coisa se compara com a outra? De facto, tanto Fídias como tu não tínheis qualquer outro meio de conhecer as partes, a não ser conhecendo o todo, quer dizer, homem e leão. No caso da filosofia, porém (por exemplo a dos estóicos), como é que, pela parte, poderias conhecer os restantes pontos da doutrina? E como é que poderias demonstrar que estes são belos? Efectivamente, náo conheces o todo de que eles são partes.

56. Quanto à tua afirmação de que é fácil apreender, numa pequena fracção do dia, os aspectos essenciais de cada sistema filosófico (como, por exemplo, os seus princípios e fins, o que pensam [da essência] dos deuses e da alma, quais é que defendem que tudo é material e quais pretendem que também há entidades imateriais, uns a considerarem que o bem e a felicidade consistem no prazer, segundo outros na beleza, e coisas do género), ao ouvi-los assim falar, é realmente fácil e nada trabalhoso formarmos uma ideia geral. Mas, quanto a ficar sabendo qual é que está a falar verdade, desconfio que isso requer, não uma fracção do dia, mas muitos dias. Senão, por que motivo esses [filósofos] deixaram, sobre tais assuntos, centenas e [mesmo] milhares de volumes ${ }^{604}$ cada um? Só para

${ }^{602}$ Melhor: "o teu exemplo de Fídias», mas, a seguir, Fidias é sujeito de acção, pelo que deve manter-se uma tradução literal.

${ }^{603}$ As representaçóes dramáticas, por serem em honra de Dioniso, deviam aludir ao deus; mas, na verdade, isso tornava-se cada vez mais raro, donde a expressão, que se tornou proverbial, "Nada para Dioniso", que passou a apli-car-se a situaçóes semelhantes.

${ }^{604}$ Não se tratava, evidentemente, de grossos tomos à maneira dos nossos livros, mas sim de rolos, de extensáo naturalmente mais reduzida. Mesmo assim, o número impressiona. 
provarem - suponho! - que são verdadeiros esses quantos pontos que se te afiguram simples e fáceis de apreender?! Ora, no que toca à escolha dos melhores pontos [de cada escola], vais precisar mas é dum adivinho, julgo eu, uma vez que não suportas debruçar-te sobre todas e cada uma e gastar muito tempo numa escolha rigorosa. De facto, esta seria rápida, sem complicaçóes nem atrasos: bastaria mandares vir o adivinho, ouvir o essencial de todas as doutrinas e fazer um sacrifício por cada uma delas. Deste modo, a divindade livrar-te-ia de mil e um problemas, ao revelar-te, no fígado da vítima, quais deverias seleccionar.

57. Mas, caso prefiras, aconselhar-te-ei um outro processo ainda menos trabalhoso, para que náo tenhas de imolar vítimas, nem sacrificar a qualquer [divindade], nem chamar alguns sacerdote desses bem pagos. Lança antes numa urna tabuinhas com o nome de cada um dos filósofos, e pede a uma criança, ainda de tenta idade e que tenha ambos os pais vivos ${ }^{605}$, que se dirija à urna e retire a primeira tabuinha que lhe vier à mão: daí em diante, estuda filosofia segundo aquele [filósofo] que te saiu - seja ele qual for.

58. Hermotimo - Ó Licino! Mas tal processo é burlesco e nem parece da tua cabeça. Ora diz-me: já alguma vez foste, em pessoa, comprar vinho?

LICINO - Sim, muitas vezes.

HERMOTIMO - E porventura percorreste um por um todos os taberneiros da cidade, provando, comparando e apreciando os vinhos?

LICINO - De modo nenhum.

HERMOTIMO - Realmente, penso eu, deves adquirir o primeiro vinho bom e barato que encontres.

LICINO - Sim, por Zeus!

HERMOTIMO - E estarias tu, com essa pequena prova, habilitado a dizer como é esse vinho no seu todo?

LICINO - Estaria, pois.

HERMOTIMO - Então e se te dirigisses aos [diversos] taberneiros e dissesses: "Meus senhores, como pretendo comprar

${ }^{605}$ Esta condição tem que ver com qualquer superstição, que Licino invoca com evidente ironia. 
um quartilho ${ }^{606}$, permita-me cada um de vós que eu beba todo o tonel, para que no fim, depois de o esgotar completamente, possa ficar a saber qual é de vós o que tem o melhor vinho e de qual devo comprar.» Se falasses assim, não achas que eles troçariam de ti e que, se continuasses a importuná-los, talvez até te atirassem com água?

LICINO - Acho, pois, e seria muito bem feito.

Hermotimo - Ora, o mesmo se passa com a filosofia. Para quê esvaziar o tonel, quando, com uma pequena prova, podemos ficar a saber como é o conjunto?

59. LICINO - Como tu és escorregadio, Hermotimo! Como te escapas por entre as máos! Apesar de tudo, porém, vieste ajudar-me: sim, cuidando que já estavas livre, acabaste por cair na própria rede.

Hermotimo - Como é isso que dizes?

LICINO - É que tu pegaste numa coisa incontroversa e conhecida de toda a gente - o vinho - e comparas com ela as coisas mais díspares e sobre as quais, [justamente] por serem controversas, toda a gente discute. Cá por mim, não sou capaz de dizer em que é que (lá no teu entendimento) a filosofia e o vinho se parecem... a náo ser, porventura, neste único ponto, a saber, que os filósofos vendem as suas lições como fazem os taberneiros: misturando-lhes água (pelo menos a maioria), enganando e falsificando as medidas. Ora, analisemos a tua exposição: afirmas tu que o vinho contido no tonel é todo ele igual a si próprio - o que, por Zeus!, nada tem de estranho. Por outro lado, se uma pessoa retirasse e provasse uma pequena quantidade, ficaria imediatamente a saber como é [o vinho de] todo o tonel - o que também é lógico, e não seria eu a contestá-lo. Mas repara bem no seguinte: a filosofia e os filósofos... por exemplo o teu mestre... Será que ele vos fala todos os dias da mesma maneira, ou um dia [fala] duma coisa, e outro dia doutra? É que, evidentemente, existem muitas matérias, companheiro. Caso contrário, não permanecerias junto dele durante vinte anos, errante e vagabundo, como Ulisses, se ele dissesse sempre a mesma coisa, pois bastar-te-ia assistir a uma única lição.

\section{Hermotimo - Como negá-lo?}

${ }^{606}$ A lotýlê, "cótila» era uma medida de líquidos mais ou menos equivalente a um quarto de litro: daí a nossa tradução por "quartilho». 
LICINO - Por conseguinte, como é que te seria possível, com base na primeira "prova", ficar a conhecer o conjunto? Efectivamente, [o mestre] não expunha sempre a mesma coisa, mas sim coisas sucessivamente diferentes - o que não se passa com o vinho, que era sempre o mesmo. Assim, companheiro, se não "esgotares todo o tonel", andas a "embriagar-te" para nada: sim, decididamente, afigura-se-me que a divindade escondeu lá no fundo, mesmo por sob as "borras", o que a filosofia tem de bom. Será, pois, necessário esgotar tudo até ao fim; caso contrário, nunca chegarás a encontrar essa tal "poção" divina, de que há tanto pareces sequioso. Tu é que cuidas que a questáo é de tal natureza, que basta apenas provar, ingerir uma pequena quantidade, para imediatamente te tornares um sábio acabado, como se diz da profetisa de Delfos: mal bebe da fonte sagrada, logo fica possessa da divindade e responde aos consulentes. Mas [no nosso] parece que não é assim: pelo menos, dizias tu que, depois de teres bebido cerca de meio tonel ${ }^{607}$, estavas ainda no começo.

61. Vê lá mas é se a filosofia não é antes parecida com o seguinte: para já, deixemos ficar o teu tonel e o taberneiro; ponha-se-lhe, dentro, porém, não vinho, mas uma mistura de sementes variadas: trigo por cima, a seguir a este, favas, depois cevada, e, sob esta, lentilhas, depois grão-de-bico, e outros géneros. Então entras tu, na intenção de comprar sementes, e ele [o lojista] retira um pouco de trigo lá donde ele estava e passa-te para a mão uma amostra, para tu a examinares. Acaso serias capaz de dizer, pela [simples] observação deste, se o grão-de-bico também estava limpo, as lentilhas tenras e as favas não completamente ocas?

HERMOTIMO - De modo nenhum.

LICINO - Portanto, também no que toca à filosofia, não se poderá saber, com base na exposição dum primeiro e único ponto, como é todo o sistema. Efectivamente, a filosofia não é um todo único, como o vinho, ao qual tu a comparas, convencido de que ela é idêntica a uma coisa que se prova, quando afinal se viu que esta [última] é algo diferente, que não necessita de exames complementares. $\mathrm{Na}$ verdade, comprar um vinho mau é um risco de [apenas] dois óbolos, ao passo que, como

${ }^{607}$ Quer dizer, passados os primeiros vinte anos dedicado ao estudo da filosofia estóica, como se lê no início do diálogo (\$ 2 e ss.). 
tu afirmaste no começo, o facto de uma pessoa se perder no meio da arraia-miúda é uma desgraça nada pequena. Por outro lado, a pessoa que pretendesse beber todo o tonel, para [depois] comprar um quartilho, prejudicaria [apenas] o taberneiro, ao fazer uma prova incrível, ao passo que, com a filosofia, não se passaria tal coisa: pelo contrário, ainda que "bebesses" tudo, em nada ficaria diminuído o "tonel", nem o "taberneiro" ficaria prejudicado, porquanto, segundo o provérbio, aquilo que vai saindo volta a entrar, ao invés do tonel das Danaides ${ }^{608}$, o qual, de facto, não retinha o que lhe metiam dentro, mas deixava-o verter para fora. Da filosofia, porém, se retirares algo, o resto fica maior.

62. Quero ainda estabelecer uma outra comparação com a "prova" filosófica - e não cuides que estou a blasfemar contra ela, ao dizer que se assemelha a um veneno mortal, como a cicuta, o acónito ${ }^{609}$ ou outro do género. Efectivamente, estes venenos, apesar de mortíferos, não matariam, desde que a pessoa raspe com a ponta da unha uma pequena, uma ínfima quantidade e prove. Sim: se essa pessoa não levar à boca a quantidade necessária [para matar], mas sim do modo indicado e com a diluição adequada, não morrerá. Tu, porém, entendias que uma pequena amostra bastaria para te proporcionar o conhecimento do todo.

63. Hermotimo - Seja como pretendes, Licino. E daí? É preciso viver cem anos e suportar tamanhos aborrecimentos? Ou não haverá outra forma de filosofar?

LICINO - De facto, não, Hermotimo. nem é de admirar... pelo menos se, no começo [deste debate], estavas a dizer a verdade: que a vida é curta e a arte longa. Mas agora, não sei por que razão, irritas-te pelo facto de hoje mesmo, antes do pôr do sol, não poderes tornar-te um Crisipo, ou um Platão, ou um Pitágoras.

${ }^{608}$ As Danaides em número de 50, mataram os maridos na noite de núpcias; por isso, Zeus castigou-as, condenando-as a encher perpetuamente um tonel com muitos furos. Trata-se dum dos suplícios perpétuos, frequentes na mitologia grega (p. ex., o suplício de Tântalo, de Sísifo, etc.).

${ }^{609}$ A cicuta é especialmente conhecida como o veneno que vitimou Sócrates. O acónito, cujas folhas e raiz contêm a aconitina (alcalóide), era (perigosamente) utilizado na medicina antiga, em doses sem sempre fáceis de administrar com segurança. 
HERMOTIMO - Ó Hermotimo, estás a trocar-me as voltas, a induzir-me em embaraço - e sem teres a mínima razão de queixa de mim... certamente por inveja de eu ir progredindo nos meus estudos, enquanto tu, ainda novo, já te desinteressaste.

LICINO - Pois sabes o que tens a fazer? Não ligues ao que eu te digo: faz de conta que estou possesso, deixa-me delirar; e quanto a ti, segue em frente o teu caminho, como até agora, e trata de acabar o que, nesta matéria, já tinhas decidido desde o princípio.

HERMOTIMO - Tu é que és um tipo duro e não me permites escolher uma filosofia sem experimentar todas.

LICINO - E no entanto, é preciso que fiques bem ciente de que nunca poderia dizer outra coisa. Ao chamares-me duro, parece-me que estás, como dizia o poeta ${ }^{610}$, a incriminar um inocente, e que eu vou continuar posto a ferros, até que venha em teu auxílio uma outra argumentação lógica, que te livre da minha dureza. Mas eis que, precisamente, essa tal argumentação veicularia uma ideia ainda mais dura; tu é que talvez a rejeites e me censures [antes] a mim.

Hermotimo - E que ideia é essa? Sim, muito me admira que essa argumentação tenha deixado alguma coisa por dizer.

64. LICINO - Segundo ela, não basta ter visto todas [as escolas] e examiná-las em profundidade, para se ficar logo em condições de escolher a melhor: falta ainda o mais importante.

HERMOTIMO - Que é que falta?

LICINO - Uma razoável bagagem crítica e analítica, meu caro, e um espírito aguçado, e uma inteligência escrupulosa e imparcial, como deve ser a que tem de julgar em assuntos desta importância; caso contrário, teria sido inútil tê-las visto a todas. Ora, diz essa argumentação que há que dedicar a tal actividade um tempo nada curto e escolher [somente] depois de as ter posto todas a descoberto, adiando [o julgamento], actuando sem pressa, observando muitas vezes, sem consideração quer pela idade de cada dissertante, quer pelo seu aspecto exterior, quer pela fama da sua sabedoria; antes deve proceder como os areopagitas ${ }^{611}$, os quais julgam de noite e na escuridão, de

${ }^{610}$ Alusão a um passo da Ilíada, em que uma personagem diz, a respeito doutra, que «seria bem capaz de incriminar um inocente» (Il., XI, 654).

${ }^{611}$ Os areopagitas eram os juízes do tribunal chamado Areópago, que tinham competência para julgar os crimes de morte premeditada, de fogo posto e de envenenamento. Mais tarde, as suas funçóes passam para 
forma que atendam, não a quem fala, mas àquilo que se fala. Só então poderás fazer uma escolha segura e dedicar-te à filosofia.

Hermotimo - Queres tu dizer: depois de morto. De facto, segundo o teu raciocínio, não há ser humano que viva o suficiente para percorrer todas as escolas e observar cada uma delas com rigor; e depois de observar, julgar; e depois de julgar, escolher; e depois de escolher, tornar-se filósofo, pois afirmas tu - só desse modo, com exclusão de qualquer outro, se acharia a verdade.

65. LICINO - Na verdade, Hermotimo, custa-me dizer-te que nem mesmo isso é suficiente, e até me dá a impressão de que temos andado a enganar-nos a nós próprios, cuidando ter descoberto um método seguro, quando não descobrimos nenhum: é como os pescadores, que, muitas vezes, tendo lançado as redes e sentindo um certo peso, as puxam, na esperança de terem apanhado uma grande quantidade de peixe; entấo, depois de se terem esfalfado a içar, surge-lhes um pedregulho ou um vaso de barro cheio de areia. Vê lá bem se também nós não "içámos" qualquer coisa do género.

HERMOTIMO - Não atinjo o que queres dizer com essas tuas redes: decididamente, estás a tentar apanhar-me nelas.

LICINO - Nesse caso, faz por te desenvencilhar, que, graças a Deus, sabes nadar como ninguém. Quanto a mim, ainda que tenhamos percorrido todos [os filósofos] à experiência, e supondo que alguma vez levemos a cabo tal tarefa, entendo que nem mesmo assim resultará óbvio se algum deles possui o "objecto" procurado ou se [ao invés] não serão todos eles ignorantes por igual.

Hermotimo - Que é que estás a dizer? Nenhum deles, absolutamente, o possui?

LICINO - É duvidoso. Ou será que te parece impossível que todos estejam enganados e que a verdade seja outra coisa, que porventura náo se encontre na posse de nenhum deles?

\section{Hermotimo - Como é isso possível?}

LICINO - Assim: suponhamos que o número certo é, por exemplo, o vinte, e que um indivíduo pega em vinte favas, fecha-as na mão e pergunta a dez pessoas quantas favas tem

a Assembleia do Povo, mas continua a funcionar como Tribunal Constitucional, instância que julgava os desertores, etc. 
ele na mão; então as pessoas fazem os seus palpites: uma diz sete, outra cinco, outra trinta, outra dez, ou quinze... numa palavra: cada uma seu número. É possível, claro, que, por sorte, alguma acerte, não é assim?

HERMOTIMO - É.

LICINO - Mas também não é impossível que todas as pessoas digam cada uma o seu número e que eles sejam todos falsos e errados, ou seja, que nenhuma delas diga que o homem tem vinte favas. Que é que achas?

HERMOTIMO - Não é impossível.

LICINO - Na mesma ordem de ideias, portanto, todos os filósofos procuram saber em que consiste a felicidade, e cada um diz sua coisa: um afirma que consiste no prazer, outro na beleza, outro noutra coisa qualquer. É verosímil que a felicidade seja uma dessas coisas, mas também não é inverosímil que seja uma outra coisa, diferente dessas todas. Dá mesmo a impressão de que andamos ao contrário do que devemos, ou seja, que nos precipitamos para o fim, sem antes termos achado o princípio. Seria necessário que, previamente, se tornasse claro que a verdade era coisa já conhecida e que, de toda a maneira, um dos filósofos a possuía de ciência certa. Depois, e só depois, viria a fase seguinte - a de investigar a quem deveríamos dar crédito.

HERMOTIMO - Portanto, Licino, tu afirmas o seguinte: ainda que tenhamos percorrido todas as correntes filosóficas, nem mesmo então ficaremos plenamente em condições de encontrar a verdade.

LICINO - Meu caro, não é a mim que o deves perguntar, mas sim, e novamente, à argumentação: sim, talvez ela te responda que náo [é possível], enquanto persistir a dúvida sobre se a verdade é alguma dessas coisas que eles dizem.

67. HERMOTIMO - Portanto, segundo as tuas palavras, nunca mais a encontraremos nem chegaremos a filósofos, pelo que devemos abster-nos de filosofias e levar [antes] uma vida normal ${ }^{612}$. Pelo menos é o que decorre das tuas palavras: que a filosofia é impossível, está fora do alcance do ser humano. Efectivamente, tu exiges que o candidato a filósofo comece por escolher a melhor doutrina; em teu entender, porém, uma tal escolha só seria rigorosa, se, após percorrermos todas as escolas filosóficas, elegêssemos então a verdadeira por excelência. Depois, fazendo

${ }^{612}$ Mais uma vez se aflora a conclusão que se vem adivinhando. 
o cálculo do número de anos necessários a cada uma, passaste das marcas, ao alongar a questão a outras geraçōes, de forma que o conhecimento da verdade ficaria para além do tempo de vida duma pessoa. E para terminar, nem isso tu consideras isento de incerteza, ao declarares que não é evidente se a verdade já terá sido descoberta pelos antigos filósofos.

LICINO - Mas serias tu capaz, Hermotimo, de afirmar sob juramento que eles já a descobriram?

HERMOTIMO - Náo, náo juraria.

LICINO - E no entanto... quantas outras coisas eu omiti propositadamente, mas que requerem, também elas, um longo exame!

\section{HeRMOTIMO - Que coisas?}

LICINO - Então não ouves [o que dizem] várias pessoas que se reclamam do estoicismo, ou do epicurismo, ou do platonismo? Uns, dizem que conhecem todos os pontos das respectivas doutrinas, outros que não - muito embora, noutros aspectos, sejam pessoas absolutamente dignas de crédito.

HERMOTIMO - Lá isso é verdade.

LICINO - Pois não te parece um bom bico-de-obra distinguir os que sabem e separá-los dos que, náo sabendo, afirmam saber?

HeRMotimo - Com certeza.

LICINO - Portanto, se te propóes vir a saber qual p melhor dos estóicos, terás de percorrê-los e experimentá-los, se não a todos, pelo menos a maioria deles, e escolher somente depois de teres exercitado e adquirido uma capacidade crítica nessas matérias não vá dar-se o caso de, por deficiência tua, ser escolhido o pior. Agora vê lá tu quanto tempo é preciso para esta diligência, que eu propositadamente deixei de lado, muito embora esse ponto seja, só por si, creio eu, o mais importante e, simultaneamente, o mais necessário em questôes de tal natureza, quero eu dizer: obscuras e controversas. É esta a tua única esperança certa e segura de caminhares na senda da verdade e de encontrá-la; outro processo não há, senão o que consiste em ganhar a capacidade de julgar, de ser capaz de separar o falso do verdadeiro e, à semelhança dos peritos em ourivesaria, distinguir as peças genuínas e não falsificadas das falsas. Oxalá vás para o exame das doutrinas apetrechado com uma tal capacidade e uma tal técnica; caso contrário, fica certo de que nada obstará a que qualquer um deles te arraste pelo nariz, ou a que vás atrás dum raminho que te póem na frente, como os carneiros; melhor ainda, 
ficarás comparável a [uma pouca de] água derramada sobre uma mesa: conduzido para onde quer que te arrastem com a ponta do dedo; ou entáo, por Zeus!, [tal e qual] uma cana que cresce na margem dum rio: dobrada ao sabor de todos os ventos, até mesmo uma leve brisa que sopre a faz abanar.

69. Assim, se porventura conseguires encontrar algum mestre abalizado na técnica da demonstração e dilucidação de matérias controversas, e que ta ensine, é claro que acabaráo os teus problemas. Com efeito, a melhor solução surgirá imediatamente, e a verdade, submetida, tal como a mentira, a esta técnica demonstrativa, será posta à prova; e tu, após teres optado e julgado com segurança, tornar-te-ás filósofo; então, uma vez alcançada a tão ansiada felicidade, viverás na sua companhia, senhor, numa palavra, de todos os bens.

Hermotimo - Bravo, Licino! Sim, o que estás a dizer é muitíssimo melhor e contém em si uma esperança nada pequena. Então, segundo parece, temos de procurar um homem em tais condiçôes, que fará de nós pessoas clarividentes, com capacidade crítica e de elevadíssimo poder demonstrativo. Assim, pelo menos as diligências subsequentes afiguram-se-me, desde já, simplificadas, livres de embaraços e sem exigirem grande dispêndio de tempo. Pela minha parte, desde já te exprimo a minha gratidão por me teres descoberto um método rápido e excelente.

LICINO - E no entanto, ainda não terias motivo para me exprimir gratidão: na realidade, não descobri nem te indiquei nada que te faça estar mais perto da esperança. Pelo contrário, ficámos muito mais longe do que estávamos antes, e, como diriam os fazedores de máximas, "depois de tanta canseira, estamos na mesma».

Hermotimo - Porque afirmas isso? Sim, tens ar de quem vai dizer algo de muito aflitivo e desesperante.

70. LICINO - É que, companheiro, mesmo que encontremos uma pessoa que afirme conhecer a arte da demonstração e que se proponha ensiná-la a outrem, não vamos logo, julgo eu, dar-lhe crédito, mas antes procuraremos alguém capaz de julgar se o nosso homem fala verdade. E mesmo que o encontremos, ainda assim é duvidoso se este juiz sabe distinguir se o outro é ou não é bom julgador, e para ele precisamos, creio eu, dum outro juiz. Sim, como é que, por nós próprios, saberíamos 
escolher a pessoa capaz do melhor julgamento? Estás a ver até onde se arrasta a questão e como ela é infindável, uma vez que nunca mais pode parar nem ser sustida? Sim, que tu aperceber-te-ás de que tais demonstraçôes (por muitas que seja possível encontrar) são discutíveis e não dão qualquer garantia de segurança. As mais delas, é claro, baseadas noutras que são discutíveis, forçam a nota para nos levarem à certa, enquanto outras, encadeando com premissas mais que evidentes outras extremamente obscuras, mas que nada têm que ver com aquelas, pretendem, mesmo assim, funcionar como provas destas últimas: é como se alguém cuidasse que poderia provar a existência dos deuses, lá porque vemos os seus altares. Assim, Hermotimo, à semelhança de pessoas que correm em círculo, eis-nos (não sei lá como) novamente chegados ao ponto de partida e ao mesmo beco sem saída ${ }^{613}$.

71. Hermotimo - O que tu me fizeste, Licino! Transformaste em cinza o meu tesouro! Pelos vistos, serão inúteis todos estes anos, tanta canseira...

LICINO - Pelo contrário, Hermotimo, afligir-te-ás muito menos, desde que te compenetres de que não és tu o único a ficar arredado desses ansiados bens, pois todos aqueles que se dedicam à filosofia lutam, por assim dizer, pela sombra dum burro $^{614}$. Senáo [vejamos]: haverá, porventura, alguém que fosse capaz de percorrer todas aquelas fases que eu referi? Tu mesmo reconheces que tal tarefa é impossível. Ora, no caso presente, afigura-se-me que te comportas exactamente como uma pessoa que chorasse e acusasse o destino, pelo facto de não lhe ser possível subir ao céu, ou mergulhar profundamente no mar e, partindo da Sicília, emergir em Chipre, ou por não ter asas para se elevar [nos ares] e, num só dia, cobrir o trajecto da Grécia até à Índia. A tua tristeza deve-se, creio eu, a teres vivido nessa esperança; ou entáo, tiveste alguma vez um tal sonho ou o fabricaste tu próprio para teu uso, sem previamente teres analisado se o teu desejo era realizável e estava de acor-

613 «beco sem saída» ou o galicismo impasse.

614 «Lutar pela sombra dum burro» é uma expressão proverbial que significa "esforçar-se para nada», pop. «trabalhar para o boneco». Nesta frase, resume Licino-Luciano a vacuidade dos estudos filosóficos como caminho para alcançar a verdade (mas náo, como se vê nos $\$ \$ 82-83$, como actividade moralizadora). 
do com a natureza humana. Ora, estavas tu, companheiro, a sonhar com tantas maravilhas, e eis senão quando a razão te deu uma ferroada que te obrigou a despertar do teu sono todo sobressaltado. Então, ainda mal podendo abrir os olhos, enfureces-te com ela, pois náo é às boas que interrompes de chofre esse sono - tal o gozo da visão que estavas a ter. $\mathrm{O}$ mesmo se passa com aqueles que fabricam para si uma felicidade imaginária: se, nesses momentos em que são ricos, ou desenterram tesouros, ou são reis, ou se sentem felizes de qualquer outro modo (tudo coisas proporcionadas por essa grande deusa, a Fantasia, que é pródiga e náo se nega a nada - mesmo que a pessoa queira transformar-se em pássaro, ou ficar do tamanho dum colosso, ou descobrir montanhas de ouro)... se, portanto, enquanto eles imaginam tais coisas, vier o criado com uma daquelas questóes do dia-a-dia, como, por exemplo, com que comprar pão, ou que é que se há-de dizer ao [senhorio] que reclama a renda e que está há que tempos à espera, ficam a tal ponto irritados por terem sido privados de todos aqueles bens pelo perguntador e perturbador, que pouco falta para arrancarem à dentada o nariz do criado.

72. Ora, querido amigo, não tenhas contra mim idêntico sentimento, se, como teu amigo que sou, não é com indiferença que te vejo a desenterrar tesouros, a voar, a conceber ideias mirabolantes, a abrigar esperanças irrealizáveis, durante uma vida inteira apegado a um sonho, porventura doce, mas, mesmo assim, sonho, mas se, pelo contrário, pretendo que acordes e passes a ocupar-te de alguma dessas coisas comezinhas, que te acompanhará até ao fim da tua vida e te faça pensar em termos comuns. Sim, o que tu, até agora, fazias e pensavas não difere em nada dos Hipocentauros, das Quimeras, das Górgonas ${ }^{615}$ e quantas outras [patranhas] são inventadas pelos sonhos, pelos poetas e pelos pintores, justamente por serem livres - coisas que

${ }^{615}$ Hipocentauros (ou simplesmente centauros), a Quimera e as três Górgonas (ou Górgones) eram monstros híbridos e horrendos, geralmente malfazejos. Os centauros tinham busto de homem e corpo de cavalo, eram seres brutais e libidinosos; a Quimera era um leão com cabeça de cabra no dorso e uma cauda que terminava em cabeça de serpente, mas também é representada com cabeça de tigre e com asas; as três Górgonas tinham a cabeça rodeada de serpentes, presas de javali, garras, asas de bronze; verdadeiramente perigosa era Medusa, cujo olhar petrificava quem a olhasse de frente. 
nunca existiram nem são susceptíveis de existir. E no entanto, a populaça, ao ver ou ouvir contar tais maravilhas, acredita nelas e deixa-se seduzir pelo seu carácter estranho e bizarro.

73. Também tu, ao ouvires um fabulista afirmar que existe uma mulher de extraordinária beleza, superior às próprias Graças ou à [Afrodite] Urânia ${ }^{616}$, sem previamente teres analisado se ele fala verdade e se existe nalgum lugar da terra uma criatura assim, ficaste logo apaixonado, tal e qual, segundo se diz. ficou Medeia por Jasão, por causa dum sonho. Mas o que, acima de tudo, te induziu à paixão (a ti e a todos quantos, como tu, se apaixonam pela mesma miragem) consistiu (pelo menos é o que me ocorre imaginar) no facto de esse fulano, ao falar de tal mulher, e aproveitando-se de terem dado crédito inicial às suas palavras, levar por diante as consequências. Realmente, vós não olháveis senão para essa coisa, e assim, mal lhe oferecestes a primeira "pega", ele tentou arrastar-vos pelo nariz e conduzir-vos até à vossa amada, por aquela que ele dizia ser a via directa. O resto é fácil, creio eu, e [de facto] ainda nenhum de vós voltou ao ponto de partida para investigar se era essa a verdadeira via, ou se não se terá equivocado ao entrar naquela que não devia; pelo contrário, ia seguindo na peugada dos que anteriormente haviam feito essa viagem, exactamente como carneiros atrás do guia, quando o que se impunha, logo à entrada e no começo, era ponderar se devia [ou não] entrar por ali.

74. Mas talvez compreendas melhor a minha exposição, se considerares uma situação mais ou menos semelhante a esta: se um desses poetas atrevidos disser que houve uma vez um homem com três cabeças e seis mãos, e se tu, logo de início, aceitares a coisa pacificamente, sem examinares se isso é possível, mas, pelo contrário, lhe deres crédito, ele poderá, desde logo, ir acrescentando tudo o mais que daí resulte: que o dito homem tinha também seis olhos, seis orelhas, emitia simultaneamente três sons de voz, comia com três bocas, tinha trinta dedos, diversamente de qualquer de nós, que tem dez em ambas as mãos; e se tivesse de ir à guerra, três das mãos seguravam, respectivamente, um escudo ligeiro, um escudo oval e um escudo redondo, enquanto, das outras três, uma brandia uma acha, outra arremessava uma

${ }^{616}$ Afrodite Urânia, "Vénus Celeste», tal como as Graças ou Cárites, eram paradigmas inultrapassáveis da beleza feminina. 
lança, e outra usava uma espada. E quem é que depois duvidaria das suas palavras? Na verdade, elas estão conformes com a premissa inicial, e a respeito desta é que se impunha ponderar, desde logo, se havia [ou não] que aceitá-la e admiti-la como válida. Ora, uma vez que concedas essas [primeiras] características, as restantes decorrem daí, nunca mais param, e já não é fácil pô-las em dúvida, visto estarem conformes e em concordância com a premissa inicialmente admitida. É justamente o que se passa convosco: náo tendo, na vossa paixáo e ardor, examinado como eram as coisas em cada entrada, ides avançando, arrastados pela consequência lógica, sem conceberdes que uma coisa, embora consequente em si mesma, pode, no entanto, ser falsa. É como se alguém te dissesse que duas vezes cinco são sete, e tu lhe desses crédito, sem antes teres efectuado o cálculo pela tua cabeça: o outro, é claro, prosseguirá, dizendo que quatro vezes cinco são exactamente catorze, e assim por diante, até onde ele quiser. É isso precisamente que a fantástica geometria faz: sim, também ela, ao propor às pessoas, inicialmente, certos postulados bizarros, ao pedir-lhes que concordem com ela em aspectos que ela não pode provar (pontos indivisíveis, linhas sem largura e coisas do género), sobre estas bases inconsistentes constrói um edifício imponente e arroga-se, a partir de dados iniciais falsos, uma verdade demonstrada.

75. Da mesma forma, também vós, ao admitirdes os princípios básicos de cada doutrina, passais a acreditar nas suas implicaçóes e tomais como garante de verdade o facto de existir uma consequência lógica, que, afinal, é enganadora. Depois, alguns de vós acabam por morrer juntamente com as esperanças, antes de terem visto a verdade e de condenarem aqueles que os enganaram; e outros, apesar de, um dia mais tarde, se aperceberem de que andaram a ser enganados, hesitam, por já serem velhos, em voltar atrás, com pejo de terem de confessar, naquela idade, que não tinham compreendido que andavam ocupados com ninharias. Deste modo, e por vergonha, persistem nas mesmas ideias, louvam a sua posição presente e tentam induzir no mesmo [erro] o maior número possível [de pessoas], só para não serem os únicos a viver enganados, mas ainda para terem a consolação de ver muitos outros na mesma situação que eles. Além disso, reparam também numa outra coisa: caso digam a verdade, deixarão de ser, como até 
agora, pessoas consideradas dignas de respeito e superiores à maioria, nem se verão tratados com a mesma deferência. Portanto, não seria de bom grado que o confessariam, cientes de que, ao caírem de tamanha altura, ficarão ao nível dos outros. Mas poucas pessoas encontrarias, que, corajosamente, ousassem confessar que haviam sido enganadas e que tentassem afastar os outros de idênticas experiências. Pois bem: se encontrares alguém assim, passa a chamar-lhe amigo da verdade, homem honrado e justo, e, já agora, filósofo. Sim, a este, e só a este, eu não recusaria tal designação. Quanto aos outros, ou não sabem nada da verdade ${ }^{617}$ (embora cuidem saber), ou então sabem, mas escondem o facto, quer por cobardia, quer por vergonha, quer pelo desejo de serem cumulados de honrarias.

76. No entanto, por Atena!, fiquemos por aqui, ponhamos de lado todas as minhas palavras: que elas sejam objecto de esquecimento, como sucedeu com os actos praticados antes do arcontado de Euclides ${ }^{618}$. Suponhamos agora que esta doutrina filosófica, a dos estóicos, é a verdadeira, com exclusão de qualquer outra, e vejamos se ela é alcançável e possível, ou se [pelo contrário] é em vão que se esforçam todos quantos aspiram a ela. Realmente, no que toca a promessas, oiço falar dalgumas maravilhas: de como seráo felizes os que chegarem ao cimo, que só esses recolherão e possuirão todos os bens autênticos; mas, quanto ao que se segue, tu o saberás melhor [que eu], se é que já encontraste algum estóico, desses tais, do topo, que nunca sinta dor, nem se deixe dominar pelo prazer, nem se encolerize, superior à inveja, que despreze a riqueza, enfim, completamente feliz. Tal pessoa deve constituir o [nosso] modelo e o critério duma vida segundo os princípios da virtude. Na verdade, uma pessoa a quem falte um poucochinho que seja, é imperfeita, e mesmo que possua todas as demais qualidades, se não possuir esse [poucochinho], ainda não é feliz.

\section{Hermotimo - Nunca vi ninguém assim.}

${ }^{617}$ Esta verdade é a consciência de nada saber.

${ }^{618}$ Euclides: arconte epónimo de Atenas em 403 a. C., depois da expulsão dos Trinta tiranos, com o que se restabeleceu a democracia. Para se evitarem represálias sobre os partidários dos tiranos, foi declarada uma amnistia geral. 
LICINO - Bravo, Hermotimo, por não teres a intenção de mentir. Portanto, com que propósito te dedicas à filosofia, depois de constatares que nem o teu mestre, nem o mestre dele, nem o seu antecessor, nem qualquer outro, mesmo recuando até à décima geraçấo, nenhum deles, enfim, chegou a ser completamente sábio e, por conseguinte, feliz? Realmente, não poderias afirmar, com razão, que te bastaria chegar muito próximo da felicidade, pois isso não adiantaria nada: sim, é a mesma coisa estar de fora, na ombreira, ou ao ar livre; estar junto da porta, ou estar longe [dela]. A diferença consistiria em que o primeiro se afligirá ainda mais, ao ver, de perto, de quantos bens se encontra privado. Além do mais, é [só] para chegares próximo da felicidade (vá lá... concedo-te este ponto) que te afadigas tanto e te esfalfas, que vens consumindo tanto tempo de vida, vergado ao peso da prostração, do trabalho e de vigílias; e ainda estás para penar, segundo dizes, mais outros vinte anos, pelo menos... para no fim, já octogenário (se é que há garantia de viveres tanto), te encontrares, apesar de tudo, no número dos que ainda não são felizes - a menos que cuides vir a ser o único a ter êxito, a perseguir e alcançar aquilo que, antes de ti, muitíssimos outros, conquanto esforçados e mais rápidos, perseguiram sem conseguir.

78. Mas (por hipótese) vá que tenhas conseguido; então, uma vez alcançado [esse bem], goza-o plenamente. Para já, não vejo que bem possa ser esse, que se considere compensador de tamanho esforço; e depois [ - pergunto - ] por quanto tempo mais usufruirás dele, já velho, fora de idade para qualquer prazer e, como sói dizer-se, com os pés para a cova $2{ }^{619} \mathrm{~A}$ menos, meu bravo, que andes a treinar-te para uma outra vida, na mira de, uma vez lá chegado, passares melhor, por já saberes de que modo se deve viver [esta vida]: tal qual como uma pessoa que gastasse tanto tempo a arranjar as coisas e a fazer os preparativos para um jantar especial, que, mal se precata, acaba por morrer de fome.

79. Mas o que tu ainda não percebeste, creio eu, é o facto de que a virtude consiste realmente nos actos, por exemplo, em agir com justiça, com sabedoria, com coragem; vós, porém ( $\mathrm{e}$ quando digo «vós» refiro-me aos filósofos de topo), desprezastes estes aspectos e [só] tratais de procurar e inventar arrevesados

${ }^{619}$ Literalmente: "com um dos pés para a cova». 
joguetes de palavras, silogismos e aporias, passando nisso a maior parte da vossa vida. E quem dominar essa técnica aparece, aos vossos olhos, como um herói; é por ela, creio eu, que vós admirais esse velho senhor, o vosso mestre: porque coloca os seus interlocutores em posição embaraçosa e sabe como deve interrogar, sofismar, enganar e induzir em becos sem saída. E vós jogais fora, ostensivamente, o "fruto" (que é o que tem que ver com os actos), preocupando-vos com a "casca" e atirando "flores" uns aos outros, lá nas vossas conferências. Ou não é senão isso, Hermotimo, que todos vós fazeis de manhã à noite?

Hermotimo - Sim, é isso mesmo.

LICINO - Não se poderia então dizer, e com razão, que vós perseguis a sombra e deixais o corpo? Que perseguis a pele da cobra e vos desinteressais do rasto? Mais: que vós agis como uma pessoa que deitasse água num almofariz e se pusesse a moê-la com um pilão de ferro, cuidando estar a fazer algo de necessário e útil, sem se aperceber de que (como sói dizer-se) "por mais que derreie os ombros à força de moer», a água continua água?

80. Mas agora deixa-me perguntar-te se (erudição à parte) gostarias de, nos outros aspectos, te parecer com o teu mestre: tão irascível, tão mesquinho, tão implicativo e até, por Zeus!, tão dado a prazeres (mesmo que não o pareça aos olhos da maioria)... Porque é que ficas calado, Hermotimo? Queres que te conte o que outro dia ouvi dizer a um homem, já muito velho, que dissertava em defesa de certa doutrina filosófica, e cuja escola é frequentada por grande número de jovens em busca da sabedoria? Pois bem: exigia ele a um dos discípulos o pagamento [das lições]; numa fúria, dizia-lhe que estava atrasado, fora do prazo de pagamento da dívida, que ele devia já ter liquidado há dezasseis dias, no dia da lua velha e nova, pois assim ficara combinado.

81. Estando ele em tal irritação, chegou o tio do jovem, homem rude e leigo na vossa matéria, o qual lhe disse: "Meu caro, acaba lá com essa conversa de estares gravemente lesado pelo facto de ainda náo termos liquidado a prestação do palavriadozeco que te comprámos. Ora, em boa verdade, tu continuas a possuir aquilo que nos tens andado a vender, e nem a tua sabedoria ficou diminuida um bocadinho sequer. Quanto ao resto, [ou seja,] a razáo primordial que me levou a confiar-te o moço, [devo dizer 
que ] a tua acção náo o tornou melhor, pois raptou e desflorou a filha do meu vizinho Equécrates, a qual era virgem; e foi por pouco que escapou a um processo por violação: se eu náo tivesse pago a Equécrates (que é pessoa pobre) um talento ${ }^{620}$ [de indemnização] pelo crime... E outro dia bateu na máe, por esta o ter surpreendido quando levava, nas pregas do manto, um barril [de vinho], para com ele contribuir, creio eu, com a sua quota-parte [numa petiscada]. Sim: no que respeita a irritabilidade, mau génio, despudor, atrevimento e mentira, há um ano atrás ele era muito melhor que hoje. No entanto, antes queria que tu o ajudasses nestes aspectos, do que [vê-lo] saber aquelas coisas que todos os dias, à hora do jantar, ele nos expóe, a nós, que náo precisamos dessas coisas para nada: que um crocodilo raptou uma criança, $e$ promete devolvê-la, se o pai dela responder não sei a que questão; ou que, sendo de dia, necessariamente não é de noite; outras vezes, o valentão, enleando as frases não sei lá como, faz-nos crescer cornos [na cabeça] ${ }^{621}$. Nós troçamos dessas ninharias, sobretudo quando ele tapa os ouvidos e medita de si para consigo sobre uns tais "estados", "relaçôes", "compreensóes", "imagens" e muitas outras coisas do género ${ }^{622}$, tudo de enfiada. Também o ouvimos dizer que Deus não está no céu, mas sim introduzido em todas as coisas, como, por exemplo, nos vegetais, nos minerais e nos animais (mesmo os mais vis). E se a mãe lhe pergunta que disparates são esses, troça dela; "Pois se eu - responde ele - aprender bem esses disparates, nada me impedirá de ser o único rico, o único rei, e de considerar os outros como uns escravos e uma escumalha em comparação comigo”.»

82. Perante tais palavras do nosso homem, vê lá, Hermotimo, que resposta lhe deu o filósofo - resposta de velho. Disse ele: "Mas se este jovem não frequentasse a minha casa, não achas que já teria praticado acçôes bem piores, ou que, por Zeus!, talvez já estivesse entregue à justiça? Pelo menos até agora, a filosofia e o seu respeito por ela têm-lhe imposto um certo freio, e por isso mesmo ele é mais moderado e, ainda assim, tolerável. Efectivamente, é ela

${ }^{620} \mathrm{O}$ talento (como o nosso velho "conto de réis") era apenas uma unidade de conto, pois representava uma quantia elevadíssima: 1 talento $=60$ minas $=6.000$ dracmas.

${ }^{621}$ Fazendo a pergunta de maneira capciosa, induz o outro à conclusão de que tem cornos...

${ }^{622}$ Trata-se da terminologia filosófica arrevesada, inacessível aos leigos. 
que lhe inspira alguma vergonha de se mostrar indigno do hábito $e$ do nome [de filósofo] - coisas que o acompanham e lhe servem de aio ${ }^{623}$. Por conseguinte, eu estaria no meu justo direito de receber de vós o pagamento: se náo por tê-lo tornado melhor, pelo menos por aquelas más acçóes que ele, por respeito à filosofia, não cometeu. Sim, até as amas dizem o seguinte a respeito das crianças: que há que mandá-las à escola, pois, mesmo que ainda não sejam capazes de aprender algo de bom, pelo menos náo farão nada de mal enquanto lá permanecem. Portanto, parece-me ter cumprido cabalmente todas as minhas obrigaçóes. Mas vem cá amanhã, chama à parte um qualquer, à tua vontade, de entre os que conhecem as nossas doutrinas, e verás como o moço interroga, como responde, que quantidade de coisas ele sabe, quantos livros já leu sobre axiomas, silogismos, compreensóes, propriedades e outras matérias várias. Se, porém, ele costuma bater na mãe ou raptar donzelas, que tenho eu a ver com isso? Sim, que vós não me instituistes seu dio..."

83. Tais foram as palavras do ancião em defesa da filosofia. E tu, Hermotimo, serias capaz de afirmar que é razão bastante estudar filosofia com este intuito, o de não praticarmos más acçôes? Ou será que, desde o início, é com outras perspectivas que pretendemos dedicar-nos à filosofia, e não com a finalidade de nos tornarmos, por essas andanças, mais decentes que o cidadão comum? Então? Porque é que não respondes também a este ponto?

HERMOTIMO - Porque havia de ser, senão por estar quase a irromper em lágrimas? Sim, pois a esse ponto me comoveu, de verdadeira, a tua argumentação; e deploro mesmo o longo tempo que, por minha desgraça, já despendi, e ainda por cima a pagar, pelas minhas atribulações, propinas elevadas. Sim, que agora, como se acabasse de me refazer duma bebedeira, estou vendo por que coisa me apaixonei e quantos males tenho sofrido por isso.

84. LICINO - Ó meu pateta! Para quê chorar? Realmente, é bem sensata, cuido eu, aquela fábula que Esopo contava.

${ }^{623}$ A palavra grega é paidagôgós, mas o port. pedagogo ganhou outro sentido; na Antiguidade greco-romana, o pedagogo (geralmente um escravo ou simples criado) acompanhava o menino à escola, transportava-lhe os apetrechos e, em especial, defendia-o de maus encontros. 
Dizia ele que certo homem, sentado à beira-mar, em zona de rebentaçáo, ia contando as ondas; cada vez, porém, que se enganava, ficava irritado, atormentava-se... até que chegou a raposa e lhe disse: "Ó meu bravo, porque te atormentas com as que ficaram para trás, quando o que é preciso é não fazer caso dessas, mas sim recomeçar a contá-las a partir de agora?" Portanto, também tu (já que tal é a tua opinião) farias bem melhor em decidir viver, daqui para o futuro, uma vida como a de toda a gente: serás um cidadão como os demais, não porás esperanças em coisas bizarras e estúpidas, nem (se fores sensato) se envergonharás pelo facto de, já velho, mudares de opinião e te passares para coisa melhor.

85. E não cuides, caro amigo, que foi por preconceito relativamente ao Pórtico, ou arrebatado por um ódio especial contra os estóicos, que eu disse tudo quanto disse; pelo contrário, as minhas palavras estendem-se a todos ${ }^{624}$. De facto, dir-te-ia precisamente a mesma coisa, se tu tivesses optado pela doutrina de Platão ou de Aristóteles e condenasses as outras indistintamente e à revelia. No caso presente, porém, e uma vez que deste a tua preferência à filosofia estóica, as minhas palavras deram a impressão de estarem dirigidas contra o Pórtico, quando nada têm de especial contra ele $e^{625}$.

86. Hermotimo - Dizes bem. Vou daqui, pois então, com este propósito: modificar até mesmo o meu aspecto exterior. Sim, dentro em breve, já não verás uma barba farfalhuda e espessa, como agora, nem um modo de vida austero, mas sim um estilo completamente descontraído e livre. Talvez até me vista de púrpura, para que toda a gente fique a saber que já não tenho nada que ver com esses disparates. Oxalá eu pudesse vomitar todas essas tretas que lhes ouvi! E podes ter a certeza de que, para tanto, não hesitaria

${ }^{624}$ Como se vê, Luciano não poupa ninguém. No entanto, é justo salientar que, mais que as doutrinas filosóficas, ele verberava sobretudo os seus representantes actuais, cheios de orgulho e de certezas absolutas. Mesmo assim, pelo seu racionalismo ou pelo desprezo pelas convençóes sociais, Luciano admira principalmente os epicuristas e os cínicos.

${ }^{625}$ Apesar desta declaração de imparcialidade, Luciano, nesta e noutras obras, disfarça mal a sua má vontade contra os idealistas e, sobretudo, contra os seus fundamentalistas, como se vê ser o caso concreto do mestre de Hermotimo. 
sequer em tomar eléboro ${ }^{626}$, mas no sentido contrário ao de Crisipo: para que não mais me lembrasse das suas palavras. Portanto, Licino, estou-te grato, e náo pouco, pois, estando eu a ser arrastado por uma espécie de torrente caudalosa e violenta, à qual, aliás, eu próprio me entregava, e indo eu por água abaixo ao sabor da corrente, tu acorreste e puxaste-me para cima, qual deus ex machina ${ }^{627}$ que ali me apareceu, como nas tragédias. Creio até que não deixaria de ter motivos para rapar o cabelo, como [fazem] as pessoas que escaparam sãs e salvas dum naufrágio; é caso para celebrar, hoje mesmo, uma acção de graças por ter sacudido de meus olhos tamanha escuridão. De hoje em diante, se alguma vez, e contra a minha vontade, ao caminhar na rua, topar com um filósofo, desviar-me-ei, evitá-lo-ei como a um cão danado.

${ }^{626}$ eléboro ou heléboro, planta utilizada pelos antigos no tratamento de doenças nervosas e do foro psíquico em geral, particularmente da loucura. Neste passo, como se vê a seguir, a sanidade mental provocada por este fármaco consistia em... fazer esquecer.

${ }^{627}$ Deus ex machina é uma expressão latina que faz parte do nosso fraseário cultural, pelo que não ficará mal numa tradução portuguesa. Corresponde ao grego theós ek mêkhanês. A «máquina» era uma espécie de grua, que baixava ao local da acção e aí depunha uma personagem vinda do céu, naturalmente uma divindade. Os trágicos (Sófocles e sobretudo Eurípides) utilizavam o processo para resolver uma trama aparentemente insolúvel: o deus, vindo do céu, punha termo ao conflito. 
(Página deixada propositadamente em branco) 


\section{Volumes publicados na ColecÇão Autores Gregos e Latinos - Série Textos Gregos}

1. Delfim F. Leão e Maria do Céu Fialho: Plutarco. Vidas Paralelas - Teseu e Rómulo. Tradução do grego, introdução e notas (Coimbra, CECH, 2008).

2. Delfim F. Leão: Plutarco. Obras Morais - O banquete dos Sete Sábios. Tradução do grego, introduçáo e notas (Coimbra, $\mathrm{CECH}, 2008)$.

3. Ana Elias Pinheiro: Xenofonte. Banquete, Apologia de Sócrates. Tradução do grego, introdução e notas (Coimbra, CECH, 2008).

4. Carlos de Jesus, José Luís Brandão, Martinho Soares, Rodolfo Lopes: Plutarco. Obras Morais - No Banquete I - Livros $I-I V$. Tradução do grego, introdução e notas. Coordenação de José Ribeiro Ferreira (Coimbra, CECH, 2008).

5. Ália Rodrigues, Ana Elias Pinheiro, Ândrea Seiça, Carlos de Jesus, José Ribeiro Ferreira: Plutarco. Obras Morais - No Banquete II - Livros V-IX. Tradução do grego, introdução e notas. Coordenação de José Ribeiro Ferreira (Coimbra, $\mathrm{CECH}, 2008)$.

6. Joaquim Pinheiro: Plutarco. Obras Morais - Da Educação das Crianças. Tradução do grego, introdução e notas (Coimbra, $\mathrm{CECH}, 2008)$.

7. Ana Elias Pinheiro: Xenofonte. Memoráveis. Tradução do grego, introdução e notas (Coimbra, CECH, 2009).

8. Carlos de Jesus: Plutarco. Obras Morais - Diálogo sobre o Amor, Relatos de Amor. Tradução do grego, introdução e notas (Coimbra, CECH, 2009).

9. Ana Maria Guedes Ferreira e Ália Rosa Conceição Rodrigues: Plutarco. Vidas Paralelas - Péricles e Fábio Máximo. Tradução do grego, introdução e notas (Coimbra, CECH, 2010).

10. Paula Barata Dias: Plutarco. Obras Morais - Como Distinguir um Adulador de um Amigo, Como Retirar Benefício dos Inimigos, Acerca do Número Excessivo de Amigos. Tradução do grego, introduçáo e notas (Coimbra, CECH, 2010). 
11. Bernardo Mota: Plutarco. Obras Morais - Sobre a Face Visivel no Orbe da Lua. Tradução do grego, introdução e notas (Coimbra, CECH, 2010).

12. J. A. Segurado e Campos: Licurgo. Oração Contra Leócrates. Tradução do grego, introdução e notas (Coimbra, CECH /CEC, 2010).

13. Carmen Soares e Roosevelt Rocha: Plutarco. Obras Morais - Sobre o Afecto aos Filhos, Sobre a Música. Tradução do grego, introdução e notas (Coimbra, CECH, 2010).

14. José Luís Lopes Brandão: Plutarco. Vidas de Galba e Otão. Tradução do grego, introdução e notas (Coimbra, CECH, 2010).

15. Marta Várzeas: Plutarco. Vidas de Demóstenes e Cícero. Tradução do grego, introdução e notas (Coimbra, CECH, 2010).

16. Maria do Céu Fialho e Nuno Simóes Rodrigues: Plutarco. Vidas de Alcibiades e Coriolano. Tradução do grego, introdução e notas (Coimbra, CECH, 2010).

17. Glória Onelley e Ana Lúcia Curado: Apolodoro. Contra Neera. [Demóstenes] 59. Tradução do grego, introdução e notas (Coimbra, CECH, 2011).

18. Rodolfo Lopes: Platão. Timeu-Critías. Tradução do grego, introduçáo e notas (Coimbra, CECH, 2011).

19. Pedro Ribeiro Martins: Pseudo-Xenofonte. A Constituição dos Atenienses. Tradução do grego, introdução, notas e índices (Coimbra, CECH, 2011).

20. Delfim F. Leão e José Luís L. Brandão: Plutarco.Vidas de Sólon e Publícola. Tradução do grego, introdução, notas e índices (Coimbra, CECH, 2012).

21. Custódio Magueijo: Luciano de Samósata I. Tradução do grego, introdução e notas (Coimbra, CECH/IUC, 2012).

22. Custódio Magueijo: Luciano de Samósata II. Tradução do grego, introdução e notas (Coimbra, CECH/IUC, 2012). 
(Página deixada propositadamente em branco) 


\section{OBRA PUBLICADA}

COM A COORDENAÇÁO

CIENTÍFICA

0
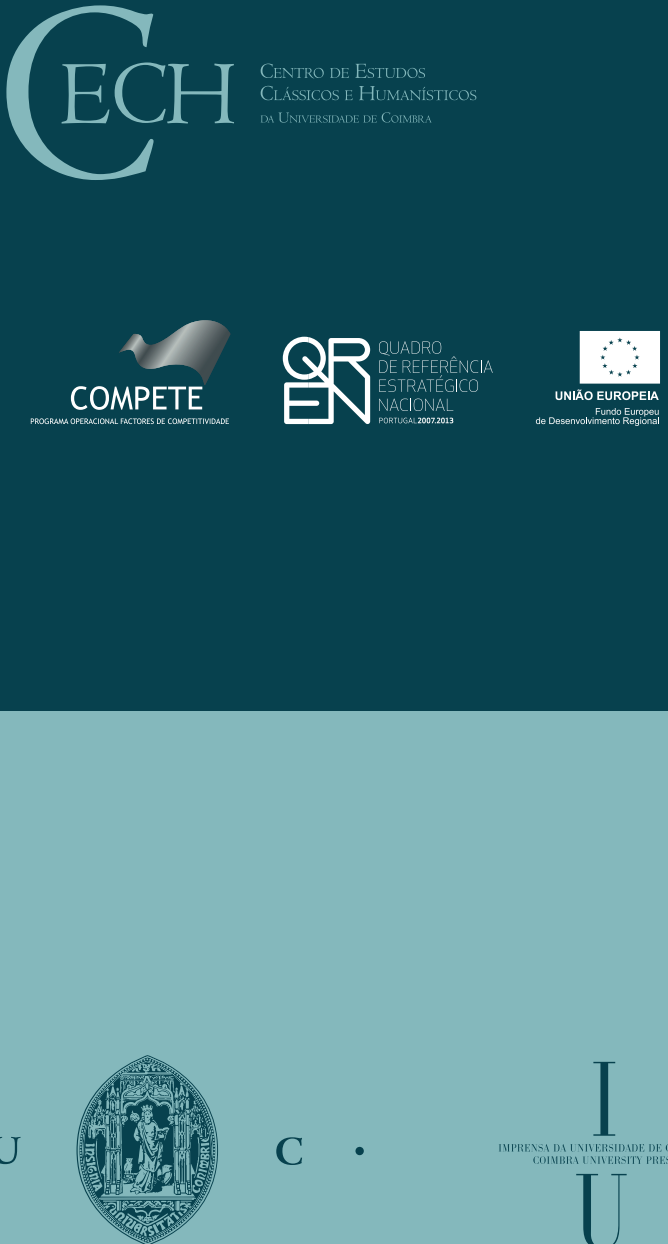

C. 